ANA PAULA CARNEIRO RENESTO

\title{
Jovens leitores em meios populares: paradoxais constituições leitoras
}

\author{
Dissertação apresentada à Faculdade de Educação da \\ Universidade de São Paulo para obtenção do título \\ de Mestre em Educação.
}

Área de Concentração: Psicologia e Educação Orientadora: Profa. Dra. Teresa Cristina Rego 
Autorizo a reprodução e divulgação total ou parcial deste trabalho, por qualquer meio convencional ou eletrônico, para fins de estudo e pesquisa, desde que citada a fonte.

Catalogação na Publicação

Serviço de Biblioteca e Documentação

Faculdade de Educação da Universidade de São Paulo

375.101 Renesto, Ana Paula Carneiro

R411j Jovens leitores em meios populares : paradoxais constituições leitoras / Ana Paula Carneiro Renesto ; orientação Teresa Cristina Rego. São Paulo : s.n., 2009.

293 p. : il., tabs.

Dissertação (Mestrado - Programa de Pós-Graduação em Educação. Área de Concentração : Psicologia e Educação) - - Faculdade de Educação da Universidade de São Paulo.

1. Vygotsky, Lev Seemenovich, 1986-1994 2. Leitura 3. Educação 4. Letramento 5. Jovens 6. Desenvolvimento humano 7. Bibliotecas 8. Singularidades 9. Psicologia I. Rego, Teresa Cristina, orient. 


\section{FOLHA DE APROVAÇÃO}

Ana Paula Carneiro Renesto

Jovens leitores em meios populares:

paradoxais constituições leitoras

Dissertação apresentada à Faculdade de Educação da Universidade de São Paulo para obtenção do título de Mestre em Educação. Área de Concentração: Psicologia e Educação

Aprovado em:

Banca Examinadora

Profa.Dra.

Instituição: Assinatura:

Profa. Dra.

Instituição:

Assinatura:

Prof. Dr.

Instituição: Assinatura: 
Para meus pais, João Augusto e Maria Amélia,

e para meu marido e minha filha, Sérgio e Renata,

todos, cada um a seu modo, tão encantados com o saber. 


\section{AGRADECIMENTOS}

Agradeço a todos que colaboraram direta e indiretamente para a realização desta pesquisa e muito especialmente:

À querida Prof ${ }^{a}$. Dra. Teresa Cristina Rego, agradeço sua orientação séria, perspicaz, instigante, encorajadora e afetuosa.

À Fundação de Amparo à Pesquisa do Estado de São Paulo (FAPESP), agradeço o apoio concedido para a realização deste trabalho.

Ao Força Ativa, agradeço o acolhimento à pesquisa.

Aos jovens que, com disposição e muita generosidade, concordaram em participar da pesquisa, agradeço seus depoimentos, com os quais muito aprendi.

À Prof ${ }^{a}$. Dra. Magda Becker Soares e à Profa. Marília Pontes Sposito, agradeço as leituras muito cuidadosas e recomendações absolutamente precisas durante o exame de qualificação.

À Profa. Marta Kohl de Oliveira, agradeço o apoio, ensinamentos e recomendações bibliográficas.

Aos docentes do programa de Pós-Graduação - Profa. Denice Catani, Prof. Emerson di Pietri, Profa. Marília Sposito e Nelson Schapochnik - agradeço os ensinamentos e sugestões metodológicas. À Profa. Marília Sposito, agradeço especialmente a indicação da Biblioteca Comunitária Solano Trindade, onde foi realizada a pesquisa empírica.

À Fernanda Arantes Silva, agradeço a gentil e solícita intermediação do contato com o Força Ativa.

Aos amigos do grupo de orientação e pesquisa da FEUSP, agradeço a rica interlocução, sempre permeada de bom humor e companheirismo, em particular à Bia, à Clarissa, ao Felipe, à Naninha e à Sandra.

Aos familiares e amigos, agradeço a companhia e solidariedade nesse percurso.

À Maria Flávia Siqueira Barbosa, querida e generosa amiga, agradeço o apoio ao longo da pesquisa e a revisão deste texto.

À minha irmã, Grá, e a meu cunhado, Lau, agradeço a escuta e as “dicas” em momentos de angústia.

À Maria Amélia, minha mãe, Lourdes e João, meus sogros, Eliana, minha cunhada, e João, meu irmão, agradeço a dedicação a minha filha, durante a finalização deste trabalho. Agradeço ainda a Lucas e Caio, meus sobrinhos, os companheirinhos de brincadeiras e de leituras de minha filha.

Agradeço imensamente ao Sergio, meu marido, pelo estímulo e companheirismo, pela escuta paciente e atenta, e, sobretudo, pelo zelo com nossa família. 
Meu sonho era ter uma biblioteca que dá de frente pra um jardim.

É o meu sonho, eu sou apaixonado por livro, por todo o conhecimento humano.

Álvares, participante desta pesquisa 


\section{RESUMO}

RENESTO, Ana Paula Carneiro. Jovens leitores em meios populares: paradoxais constituições leitoras. 2009. 293 fls. Dissertação (Mestrado em Educação) - Faculdade de Educação. Universidade de São Paulo, São Paulo, 2009.

Tendo por base teórica a perspectiva histórico-cultural do desenvolvimento psicológico humano, esta pesquisa investigou a constituição leitora de jovens nas camadas populares da cidade de São Paulo. A coleta de dados para análise consistiu de entrevistas com 13 sujeitos entre 17 e 31 anos, usuários de uma biblioteca comunitária na cidade de São Paulo. Inicialmente, buscou-se investigar a constituição de leitores literários. Uma vez em campo, alargou-se o espectro de investigação para outros leitores. Os resultados evidenciaram que o processo de constituição leitora não foi homogêneo, linear nem tampouco mecânico. Ao contrário, ele foi possível graças a configurações sempre singulares de fatores interdependentes que contribuíram para a gênese do interesse por ler. Dentre tais fatores estiveram: a freqüência de acesso a material impresso e sua qualidade; o poder de entretenimento desse material, em especial na infância, a identificação com a temática de algumas obras, e, por outro lado, o caráter exótico de outras obras; uma relação positiva com o saber e a percepção de si como excelente aluno; e acima de tudo as oportunidades de contato com leitores mais experientes $\mathrm{O}$ convívio com leitores mais maduros deu-se em diferentes configurações de âmbitos, os quais assumiram diversos graus de importância na constituição leitora de cada um. A maior parte dos sujeitos que tiveram oportunidade de conviver com tais leitores mais experientes durante a infância e adolescência na família, na escola básica, entre os vizinhos, namorados, ou no grupo de estilo tornaram-se leitores literários. Para os outros sujeitos - a que se chamou leitores - que não conviveram com leitores mais experientes ou o fizeram mais raramente, o desenvolvimento de práticas de leitura deu-se mais tardiamente, a partir dos 17 anos, quando encontraram tais mediadores mais experientes na biblioteca comunitária e se envolveram em projetos de transformação social, o que favoreceu o desenvolvimento do prazer e do sentido de saber. Do ponto de vista teórico, foram levados em consideração os estudos sobre leitura e letramento de Magda Becker Soares, Marisa Lajolo, Regina Zilberman e Ivani Ratto, as análises sociológicas de Pierre Bourdieu, Bernard Charlot, Bernard Lahire e Maria José Viana, as reflexões sobre a sociabilidade juvenil, a escola e os grupos de estilo realizadas por Marília Pontes Sposito e Juarez Dayrell e os estudos sobre a perspectiva vygotskiana do desenvolvimento humano, a escolarização e o letramento, conduzidos por Marta Kohl de Oliveira e Teresa Rego.

Palavras-chave: Leitura. Letramento. Educação. Jovens. Desenvolvimento humano. Singularidade. Psicologia histórico-cultural. Biblioteca. 


\begin{abstract}
RENESTO, Ana Paula Carneiro. Young readers in the working class: paradoxical reader constitutions. 2009. 293 pages. Dissertation (Master's) - Faculdade de Educação. Universidade de São Paulo, São Paulo, 2009.

This qualitative study aimed at investigating the constitution of young readers in the working classes of São Paulo city, from the cultural-historical perspective of the human psychological development. Data collection consisted of interviews with 13 subjects aged 17 to 31, who are users of a community library. At first it aimed at studying the constitution of literary readers. In the field, the research spectrum was enlarged and included other readers. Results showed that the reader constitution process was not homogeneous, linear or mechanical. On the contrary, such constitution was possible thanks to singular configurations of interdependent factors that contributed to the genesis of an interest in reading. Among such factors were: the development of a positive relationship with knowledge and of a self-image excellent student; reasonably frequent access to printed material and its high quality; the entertaining power such material had, especially during one's childhood, one's identification with the theme of some works and, on the other hand, the exotic characteristics of other works; and most importantly, the opportunities of being in contact with more experienced readers. The contact with such more experienced readers took place in different ambit configurations, and each ambit had various degrees of importance for each person's reading constitution. Most of the subjects that had the chance to have contact with such more experienced readers during their childhood and adolescence in their family, at school and among neighbors, friends or in the style group became literary readers. Most of the subjects who did not have frequent contact with more experienced readers or did have it but only very rarely during their childhood and adolescence, did not develop reading practices until the age of 17, when they met such more experienced readers in a community library and were involved in social transformation projects, which favored the development of a meaningful and pleasant relationship with knowledge. Data was analyzed from the theoretical point of view of studies on reading and literacy by Magda Becker Soares, Marisa Lajolo, Regina Zilberman and Ivani Ratto, sociological analyses by Pierre Bourdieu, Bernard Charlot, Bernard Lahire and Maria José Viana, investigations on juvenile sociability, education and style groups by Marília Pontes Sposito and Juarez Dayrell, and studies on Vygotsky's perspective of human development, schooling and literacy conducted by Marta Kohl de Oliveira and Teresa Rego.
\end{abstract}

Key words: Reading. Literacy. Education. Youngsters. Vygotsky. Human development. Singularity. Cultural-historical psychology. Library. 


\section{LISTA DE ABREVIATURAS}

\begin{tabular}{|c|c|}
\hline $\mathrm{BC}$ & Biblioteca comunitária \\
\hline BCST & Biblioteca Comunitária Solano Trindade \\
\hline $\mathrm{BE}$ & Biblioteca escolar \\
\hline BP & Biblioteca pública \\
\hline $\mathrm{EF}$ & Ensino Fundamental \\
\hline EFI & $1^{\mathrm{o}}$. segmento do Ensino Fundamental ( $1^{\mathrm{a}}$. à $4^{\mathrm{a}}$. séries $)$ \\
\hline EFII & $2^{\circ}$. segmento do Ensino Fundamental ( $5^{\mathrm{a}}$. à $8^{\mathrm{a}}$. séries $)$ \\
\hline EM & Ensino médio \\
\hline FA & Força Ativa \\
\hline LD & Livro didático \\
\hline LP & Língua Portuguesa \\
\hline OME & Outras modalidades de escolarização \\
\hline $\mathrm{PCN}$ & Parâmetros Curriculares em Ação \\
\hline PNLD & Programa Nacional do Livro Didático \\
\hline PNLEM & Programa Nacional do Livro para o Ensino Médio \\
\hline
\end{tabular}




\section{SUMÁRIO}

Introdução

Capítulo 1 - A improvável formação de leitores nas camadas populares

1.1 Leitura e (não) leitores no Brasil 25

$\begin{array}{ll}\text { 1.1.1 Acesso } & 28\end{array}$

1.1.2 Penetração da leitura 29

1.1.3 Formação de leitores: a família e a escola 31

1.2 A leitura literária e uma acepção de literatura 33

1.3 Pensamento e linguagem na perspectiva de Vygotsky 39

1.4 O abismo entre a literatura e a escola, entre a escola e as camadas populares 45

Capítulo 2 - Em busca da compreensão de constituições leitoras paradoxais 53

2.1 Pesquisas acadêmicas sobre a formação de leitores $\quad 55$

2.2 Para além das categorias macro-sociais: a singularidade humana em foco $\quad 61$

2.3 Quando a escola inexistiu ou foi inócua: possibilidades de letramento extra- 81 escolar

Capítulo 3 - Metodologia $\quad 93$

3.1 Objetivos da pesquisa $\quad 95$

3.2 Planejamento do trabalho de campo 96

3.3 O local de coleta de dados $\quad 98$

$\begin{array}{ll}\text { 3.4 Da intenção ao ato: a coleta de dados } & 104\end{array}$

Capítulo 4 - Análise de dados

4.1 Apresentação dos dados: perfil dos sujeitos participantes da pesquisa 113

4.2 Grupo A - os leitores: $\quad 115$

AK47, André, Dandara, Frida, Laís, Maria, Marley e Paula

4.3 Grupo B - os leitores de literatura:

Álvares, Beatriz, Malik, Taiko e Zapata

4.4 Frequiência e formas de acesso ao material impresso 126

4.4.1 O acesso a material impresso pelo grupo A (os leitores) 132

4.4.2 O acesso a material impresso pelo grupo B (os leitores de literatura) 136

4.4.3 O acesso a material impresso: comparando os grupos $A$ e $B \quad 138$ 
4.5 A mediação de leitura no âmbito da família

4.5.1 A mediação de leitura pela família - Grupo A (os leitores)

4.5.2 A mediação de leitura pela família - Grupo B (os leitores de literatura)

4.5.3 A mediação de leitura pela família: comparando os grupos $A$ e $B$

4.6 A mediação de leitura no âmbito da escola

4.6.1 A mediação de leitura na escola - Grupo A (os leitores)

4.6.2 A mediação de leitura na escola - Grupo B (os leitores de literatura)

4.6.3 A mediação de leitura na escola: comparando os grupos $A$ e $B$

4.7 A mediação de leitura no âmbito da biblioteca

4.7.1 A biblioteca escolar

4.7.1.1 A biblioteca escolar e o grupo A (os leitores)

4.7.1.2 A biblioteca escolar e o grupo B (os leitores de literatura)

4.7.1.3 A biblioteca escolar: comparando os grupos A e B

4.7.2 A biblioteca pública

4.7.2.1 A biblioteca pública e o grupo A (os leitores)

4.7.2.2 A biblioteca pública e o grupo B (os leitores de literatura)

4.7.2.3 A biblioteca pública: comparando os grupos A e B

4.7.3 A biblioteca comunitária

4.7.3.1 A biblioteca comunitária e o grupo A (os leitores)

4.7.3.2 A biblioteca comunitária e o grupo B (os leitores de literatura)

4.7.4 As bibliotecas escolar, pública e comunitária: comparando os grupos A e B

4.8 A mediação de leitura pelo grupo de pares

4.8.1 A mediação de leitura pelo grupo de pares - Grupo A (os leitores)

$5.1 \mathrm{~A}$ resposta às questões que nortearam a pesquisa 253

5.2 Alguns comentários finais $\quad 266$

$\begin{array}{ll}\text { Referências bibliográficas } & 273\end{array}$

$\begin{array}{ll}\text { Anexos } & 285\end{array}$

$\begin{array}{ll}\text { Anexo A - Autorização para a pesquisa } & 287\end{array}$

Anexo B - Lista de objetivos da pesquisa 289

Anexo C - Roteiro de entrevista 291

Anexo D - CD-ROM - Transcrições das entrevistas 293 


\section{Introdução}

[Ela] possuía o que qualquer criança devoradora de histórias gostaria de ter: um pai dono de livraria.

Pouco aproveitava. E nós menos ainda: até para aniversário, em vez de pelo menos um livrinho barato, ela nos entregava em mãos um cartão-postal da loja do pai. Ainda por cima era de paisagem do Recife mesmo, onde morávamos, com suas pontes mais do que vistas. Atrás escrevia com letra bordadíssima palavras como "data natalícia" e "saudade".

Mas que talento tinha para a crueldade. [...] Na minha ânsia de ler, eu nem notava as humilhações a que ela me submetia: continuava a implorar-lhe emprestados os livros que ela não lia.

Até que veio para ela o magno dia de começar a exercer sobre mim uma tortura chinesa. Como casualmente, informou-me que possuía As reinações de Narizinho, de Monteiro Lobato.

Era um livro grosso, meu Deus, era um livro para se ficar vivendo com ele, comendo-o, dormindo-o. E completamente acima de minhas posses. Disse-me que eu passasse pela sua casa no dia seguinte e que ela o emprestaria.

Até o dia seguinte eu me transformei na própria esperança de alegria: eu não vivia, nadava devagar num mar suave, as ondas me levavam e me traziam.

No dia seguinte fui à sua casa, literalmente correndo. Ela não morava num sobrado como eu e sim numa casa. Não me mandou entrar. Olhando bem para meus olhos, disse-me que havia emprestado o livro a outra menina, e que eu voltasse no dia seguinte para buscá-lo. Boquiaberta, saí devagar, mas em breve a esperança de novo me tomava toda e eu recomeçava na rua a andar pulando, que era meu modo estranho de andar pelas ruas de Recife. Dessa vez nem caí: guiava-me a promessa do livro, o dia seguinte viria, os dias seguintes seriam mais tarde a minha vida inteira, o amor pelo mundo me esperava, andei pulando pelas ruas como sempre e não caí nenhuma vez.

Mas não ficou simplesmente nisso. O plano secreto da filha do dono da livraria era tranqüilo e diabólico. No dia seguinte lá estava eu à porta de sua casa, com um sorriso e o coração batendo. Para ouvir a resposta calma: o livro ainda não estava em seu poder, que eu voltasse no dia seguinte.

[...]E assim continuou. Quanto tempo? Não sei. [...] Eu ia diariamente à sua casa, sem faltar um dia sequer. Às vezes ela dizia: pois o livro esteve comigo ontem de tarde, mas você só veio de manhã, de modo que o emprestei a outra menina. E eu, que não era dada a olheiras, sentia as olheiras se cavando sob os meus olhos espantados.

Até que um dia, quando eu estava à porta de sua casa, ouvindo humilde e silenciosa a sua recusa, apareceu sua mãe. Ela devia estar estranhando a aparição muda e diária daquela menina à porta de sua casa. Pediu explicações a nós duas. Houve uma confusão silenciosa, entrecortada de palavras pouco elucidativas. A senhora achava cada vez mais estranho o fato de não estar entendendo. Até que essa mãe boa entendeu. Voltou-se para a filha e com enorme surpresa exclamou: mas este livro nunca saiu daqui de casa e você nem quis ler!

E o pior para essa mulher não era a descoberta do que acontecia. Devia ser a descoberta horrorizada da filha que tinha. Ela nos espiava em silêncio. [...] Foi então que, finalmente se refazendo, disse firme e calma para a filha: "você vai emprestar o livro agora mesmo". E para mim: "e você fica com o livro por quanto tempo quiser". Entendem? Valia mais do que me dar o livro: "pelo tempo que eu quisesse" é tudo o que uma pessoa, grande ou pequena, pode ter a ousadia de querer $[\ldots]$

Clarice Lispector 
Recordo-me de minha imagem de felicidade na juventude ter sido estar em casa, numa cadeira de balanço, numa varanda, com um bom livro nas mãos. Identifico-me com a protagonista do conto de Clarice Lispector - que tem o significativo título Felicidade Clandestina - no que diz respeito a sua ânsia de ler, algo que me lembro ter amado fazer particularmente a partir dos oito anos, a ponto de ter optado pela graduação em Letras para dedicar-me ao (ou deliciar-me com o?) estudo de literatura. No entanto, ao final da graduação, em 1992, enveredei por caminhos que me levaram a atuar predominantemente como professora de língua estrangeira.

Em 2004, voltei à universidade para o curso de Licenciatura em Língua Portuguesa na Faculdade de Educação da Universidade de São Paulo, o que me colocou frente a frente com o problema da formação leitora. Era-me então francamente impossível compreender como alguém poderia afirmar não gostar de ler. Por outro lado, refletindo sobre minha própria formação, também não percebia que fatores haviam contribuído para que eu tivesse me tornado uma leitora tão ávida desde a infância. Parecia-me que minhas práticas de leitura não haviam sido fomentadas nem por minha família nem pela escola. Mais tarde reveria tal impressão, em especial no que diz respeito ao papel que meus pais haviam exercido.

Em 2005, atendendo a um requisito do curso de Licenciatura, realizei 300 horas de estágio em salas de $6^{a}$. e $7^{\text {a }}$. séries numa escola pública no centro do bairro de Santo Amaro, em São Paulo. Embora tal escola dispusesse de ampla biblioteca, não parecia favorecer o desenvolvimento de hábitos de leitura. Ao contrário, a leitura e o ato de estudar eram apresentados como algo difícil, aborrecido e desprovido de sentido, uma espécie de "mal necessário", um remédio amargo que alunos e professora de Língua Portuguesa deviam estoicamente suportar até que (finalmente!) tocasse o sinal do final da aula. Desnecessário dizer que a grande maioria das crianças, de fato, não lia ou lia o estritamente necessário para não ser reprovado. Havia, porém, dois ou três alunos que constituíam exceção e que estavam envolvidos na elaboração de uma apresentação de poesias, atividade organizada pela professora de Geografia. Perguntei-me: o que haveria de diferente na formação desses alunos? Por que eles liam de modo espontâneo e autônomo enquanto a maioria não?

Outra questão que me intrigava, abordada literariamente por Clarice Lispector, era uma aparente não correlação direta entre o capital cultural de que se dispunha - objetivado em livros, por exemplo, ou incorporado no grau de escolarização da família e do próprio sujeito e o desenvolvimento de práticas de leitura. Em outros termos, perguntava-me por que nascer entre livros, ser filho de pais escolarizados e freqüentar boas escolas-como é aparentemente o caso da filha do dono de livraria - não era necessariamente sinônimo de vir a apreciar ler. 
Ainda na Licenciatura, em 2005, quando fui aluna da disciplina Psicologia e Educação, tive a oportunidade de entrar em contato com a perspectiva histórico-cultural do desenvolvimento humano por meio do curso ministrado pela professora Teresa Rego. Tal abordagem logo despertou o meu interesse, pois me pareceu, em contraposição às teorias ambientalistas e inatistas, ser a que melhor explicava as singularidades que percebia nos alunos que - assim como a filha do dono da livraria - dispunham de condições vantajosas para desenvolver práticas de leitura, mas não o faziam e naqueles que - assim como a protagonista do conto de Clarice - aparentemente enfrentavam barreiras ao desenvolvimento de práticas de leitura e, ainda assim, liam avidamente.

À medida que refletia sobre o estágio, o tema da formação leitora foi me instigando cada vez mais, a ponto de suscitar a escrita de um projeto de pesquisa em nível de mestrado.

Com esta dissertação, cumpri um plano de trabalho, aprendi enormemente sobre o tema e sobre mim mesma, venci algumas dificuldades e vislumbrei outras possibilidades de investigação. Tenho clareza do quanto o campo da formação leitora é amplo e quão absolutamente pouco pude contribuir com meus estudos. Conto com meus leitores, com meus sujeitos e, em especial, com minha banca de mestrado, para ajudar-me a melhorar este trabalho com seus comentários, que certamente serão valiosíssimos também para orientar as etapas seguintes de meus estudos.

\section{O problema investigado}

Embora tenha havido no Brasil uma expansão considerável no acesso ao ensino fundamental ao longo do século XX, hoje com cobertura praticamente universal, a tal expansão não correspondeu um aumento do desenvolvimento de práticas de leitura, em especial, entre as camadas mais desfavorecidas da população, o que configura um quadro de improbabilidade estatística de formação de leitores nas camadas populares.

Nosso objeto de estudo foi a constituição de jovens leitores literários em condições adversas: filhos de famílias com baixo capital econômico e cultural, não imersos em ambiente de letramento, alunos de escolas de qualidade sabidamente baixa, moradores de bairros com baixo índice de desenvolvimento humano. 
Nossa pesquisa foi norteada por dois grupos de questões, a saber: a) o que influenciou a gênese ${ }^{1}$ do interesse por ler? A freqüência de acesso a material impresso e sua qualidade tiveram algum tipo de influência? e b) qual foi a frequiência da interação com os mediadores leitores mais experientes? O contato foi constante, esporádico ou até mesmo único? Em que âmbito e como aconteceu a mediação?

\section{Percurso da reflexão}

Ao longo de meu percurso na pós-graduação, dediquei-me ao estudo da questão do desenvolvimento psicológico humano na perspectiva da Psicologia histórico-cultural, em especial, os vários planos de desenvolvimento (filogenético, sociogenético, ontogenético e microgenético) que interatuam no processo de constituição do ser humano. Nessa ótica, procurei compreender, especialmente, as relações entre fala e pensamento e entre letramento, escolarização e modalidades de pensamento, a cultura escolar e a constituição de singularidades. Alguns dos autores lidos foram: Bruner e Weisser (1995), Charlot (2001), Elias (1994), Goody e Watt (1968), Kleiman (1995), Lahire (1997), Oliveira (1999, 2002, 2003), Oliveira, M. B. e Oliveira, M. K. (1999), Patto (1990, 1997), Pino (1990, 2000, 2005), Rego (1995, 1998, 2003), Rosa e Valsiner (2007), Rossetti-Ferreira et al (2004).

Smolka (2002, 2004), Smolka e Góes (1993), Veer, R. V. D. e Valsiner, J. (1991, 1994, 1996), Vygotsky (1991), Vygotsky e Luria (1996).

Paralelamente, busquei situar-me histórica e teoricamente no amplo e multidisciplinar campo de estudos sobre a leitura e a formação do leitor, perscrutando a diversidade teórica das abordagens e a historicidade das práticas de leitura, de modo a melhor circunscrever meu objeto de estudo. Alguns dos autores lidos foram: Barbier e Lavenir (1999), Barthes e Compagnon (1987), Chartier (1996), Chartier e Hébrard (1995), Compagnon (1999), Darnton (1987, 1990), Lyons (1999), Lyons e Leahy (1999).

Procurei ainda ler uma bibliografia que tratasse da leitura e da formação leitora especificamente no Brasil. Dentre as principais obras lidas, estiveram Abreu (1999, 2000, 2004), Lacerda (2003), Lajolo (2001, 2003), Rangel (2005), Ribeiro (1999, 2003), Soares (1998, 2001, 2004, 2005), Zilberman (2005) e os vários títulos publicados pelo Centro de

\footnotetext{
1 O termo gênese é usado na psicologia histórico-cultural com no sentido de desenvolvimento, formação, de constituição, de conjunto de elementos que contribuem para a produção de algo e não no sentido apenas de origem.
} 
Alfabetização, Leitura e Escrita (CEALE) da Faculdade de Educação da Universidade Federal de Minas Gerais, em particular aqueles que trataram do tema do letramento literário.

Num segundo momento, cursei uma disciplina no Departamento de Linguagem, ministrada pelo professor Emerson de Pietri, cujo objetivo foi estabelecer um diálogo entre diferentes concepções de linguagem, pensamento e ensino da perspectiva da Lingüística, da Psicologia e da Filosofia. Alguns dos autores lidos foram Bakhtin (1979), Chartier (2002), Chomsky (1971), Deleuze (1974), Frege (1978), Maingueneau (2005), Pêcheux (1988), Piaget (1973), Piaget e Chomsky (1983), Vygotsky (1988). E também, Saussure e Benveniste.

Paralelamente, realizei estudos sobre a sociologia bourdieusiana, com vistas a melhor compreender o diálogo que sociólogos como Charlot, Lahire e Dubet - que haviam embasado meu projeto de pesquisa inicial - com ela haviam estabelecido. Alguns dos textos lidos foram: Bourdieu (1974, 1975, 1983, 1996, 1997, 1998, 2005a, 2005b), Bourdieu e Passeron (1982), Nogueira e Catani (1999), Nogueira e Nogueira (2004). A leitura de Bourdieu inspirou a elaboração das perguntas para a entrevista semi-estruturada e minha postura enquanto pesquisadora frente aos sujeitos. À medida que me aprofundava nos estudos sobre a sociologia de Bourdieu, a formação leitora e a mediação da literatura pela escola, mais remota me parecia a possibilidade de encontrar os sujeitos que buscava para realizar a pesquisa empírica. Passei a temer pela exeqüibilidade de meu estudo: tinha dúvidas sobre se encontraria jovens leitores em meios populares.

Recebi então a sugestão do Prof. Nelson Schapochnik a recomendação de abandonar a esfera do Estado, ou seja, de parar de considerar apenas as bibliotecas públicas quando pensasse em bibliotecas: seria mais fácil localizar os sujeitos de minha pesquisa em bibliotecas comunitárias, normalmente localizadas em bairros mais periféricos, nos quais praticamente inexistem as bibliotecas públicas. Realizei logo a seguir uma entrevista com uma adolescente de 14 anos, usuária de uma incipiente biblioteca comunitária na região de Parelheiros, na cidade de São Paulo. A partir de tal entrevista, confirmei que as bibliotecas comunitárias seriam indubitavelmente o melhor local de recrutamento de sujeitos. Realizei também uma mudança no corte etário destes, que de 14 a 16 anos, passou para 18 a 24 anos, pois seria desejável entrevistar sujeitos que tivessem concluído ou estivessem em vias de concluir o Ensino Médio.

Às vésperas de entrar em campo, cursei uma disciplina sobre métodos de pesquisa em sociologia, ministrada pela professora Marília Sposito, o que configurou uma excelente oportunidade de reflexão sobre o projeto. Entre os autores lidos, estiveram Bourdieu (1997), Brandão (2002), Lenoir (1996), Melucci (2005), Mills (1965), Pais (2003) e Zanten (2003, 
2004). Tendo apresentado meu projeto a colegas pós-graduandos, recebi da docente a sugestão de recrutar os sujeitos numa biblioteca comunitária da zona leste da cidade de São Paulo, e assim o fiz.

O trabalho de campo, realizado entre dezembro de 2007 e março de 2008, e que consistiu de treze entrevistas semi-estruturadas com os leitores usuários da referida biblioteca, por um lado, fez emergir novas necessidades de pesquisa teórica e, por outro, demandou uma melhor circunscrição do referencial teórico. Além disso, em função da complexidade dos dados obtidos no campo, muito maior do que havia eu suposto durante minha pesquisa teórica - afinal, havia nele inusitados leitores não literários que faziam leituras extremamente sofisticadas de obras de Filosofia, História e Sociologia -, ao invés de me ater apenas aos leitores de literatura, entrevistei leitores de livros, quer fossem literários ou não.

Já com a pesquisa de campo realizada, sentia que meu maior desafio seria circunscrever o quadro teórico. Foi justamente essa uma das principais recomendações da banca durante o exame de qualificação ${ }^{2}$, a qual fez também indicações bibliográficas absolutamente precisas. Fui instada ainda a tomar uma posição no interior da polêmica do que seria literatura e a definir o que estava chamando de leitores.

Desde então, embrenhei-me nos textos de autores que defendiam a inclusão de um abrangente leque de produções naquilo que se chama literatura e daqueles que apontavam para uma necessária hierarquização dos textos e a circunscrição do que se considera literatura. Refleti longamente até me convencer (e conseguir desenvolver argumentos para convencer o outro) da posição assumida em favor da circunscrição do termo literatura. Queria ter certeza de que a posição assumida não era mero reflexo de minha formação em Letras, mas sim, acima de tudo, a mais coerente com a perspectiva histórico-cultural adotada e com as informações que emergiam dos dados coletados.

Quando da análise dos dados, diferenças muito significativas na constituição de sujeitos leitores (aqueles que liam livros) e de sujeitos leitores literários (aqueles que liam livros e incluíam os clássicos da literatura em seu leque de leituras, compreendiam-nos e apreciavam-nos) foram se tornando perceptíveis. Em primeiro lugar, os leitores de literatura haviam se constituído leitores antes de conhecerem a biblioteca comunitária onde foi realizada a pesquisa, enquanto que a maioria dos outros leitores havia passado a desenvolver leituras de livros com regularidade apenas depois de conhecê-la e muito em função da mediação de leitura que nela se dava.

\footnotetext{
${ }^{2}$ A banca do exame de qualificação foi composta pela Profa. Magda Becker Soares e pela Profa. Marília Pontes Sposito.
} 
A comparação entre esses dois grupos possibilitou responder às perguntas que nortearam a pesquisa. Permitiu também compreender os motivos do sucesso da mediação de leitura no interior daquela biblioteca comunitária, um equipamento de tão parcos recursos materiais, mas de muitos recursos culturais e simbólicos para a reversão de um quadro de improbabilidade estatística de formação leitora entre os jovens das camadas mais empobrecidas da população. Tal comparação forneceu também subsídios para fazer uma proposta de fomento a práticas leitoras em regiões da cidade não atendidas por bibliotecas públicas.

Para a análise e compreensão das estatisticamente improváveis constituições leitoras de grande parte dos sujeitos, foi necessário, além de retomar Charlot (2001, 2005), Lahire (1997, 1998) e Rego (2003), fazer leituras de autores que tratavam especificamente de jovens, grupos de estilo e, em especial, o rap - Sposito (1993, 2005, 2007, 2008), Dayrell (2005) e Abramo (1992) - e de autores que abordavam possibilidades de letramento extra-escolar Oliveira (1995) e Ratto (1995) -, além de um estudo sobre longevidade escolar nas camadas populares (Viana, 2007).

Para a produção desta dissertação, além da busca por uma bibliografia significativa de diferentes áreas do conhecimento (História da Leitura, Letramento, Psicologia e Sociologia), as disciplinas que freqüentei no programa de pós-graduação foram importantíssimas para que eu me localizasse no multifário campo da leitura e da formação leitora e conseguisse assim viabilizar minha pesquisa. Espero que os professores dessas disciplinas possam reconhecer aqui sua contribuição.

Além desses estudos, ao longo de 2006, 2007 e 2008, participei do grupo de pesquisa composto pelos orientandos da Profa. Dra. Teresa Rego, cujas atividades incluíram a leitura e discussão das obras de Vygotsky, de textos sobre metodologia, dos projetos de pesquisa dos orientandos, o levantamento e a troca de informações bibliográficas e a leitura de dissertações e teses de interesse do grupo. Beneficiei-me da valiosíssima interlocução que se deu nesses encontros para o aprimoramento de meu projeto de pesquisa e para a tomada de decisões metodológicas.

Este texto foi organizado em cinco capítulos. O meu percurso teórico foi apresentado em dois capítulos. O primeiro deles trata de aspectos diversos que configuram um quadro de improbabilidade estatística de formação leitora nas camadas populares. No segundo capítulo, abordo fatores que, em interdependência e em configurações sempre singulares, contribuíram para a paradoxal constituição leitora de sujeitos que não nasceram entre livros. No capítulo 3, apresento a metodologia adotada. O capítulo 4 traz a análise dos dados coletados, dividida nos 
âmbitos acesso, família, escola, biblioteca e grupos de pares. O âmbito instituições religiosas, embora inicialmente previsto, não foi abordado, dada sua irrelevância para a constituição da maior parte dos sujeitos. No contexto do grupo de pares, analisei em particular o grupo de estilo rap. No capítulo 5, organizei algumas considerações finais. Por último, apresento as Referências Bibliográficas, os Anexos. Em Anexos, encontram-se a Autorização para a pesquisa, a Lista de objetivos da pesquisa, o Roteiro de entrevista e um CD-ROM com as transcrições das entrevistas com os 13 sujeitos da presente pesquisa. 
Capítulo 1

\section{A improvável formação de leitores nas camadas populares}

Gosto de sentir a minha língua roçar A língua de Luís de Camões

Gosto de ser e de estar

E quero me dedicar A criar confusões de prosódias

E uma profusão de paródias

Que encurtem dores

E furtem cores como camaleões

Gosto do Pessoa na pessoa

Da rosa no Rosa

[...]

E deixa os portugais morrerem à míngua

"Minha pátria é minha língua"

Fala mangueira!

Fala!

Flor do Lácio Sambódromo

Lusamérica latim em pó

$O$ que quer

O que pode

Esta língua?

[...]

A língua é minha pátria

E eu não tenho pátria: tenho mátria

E quero frátria

Poesia concreta e prosa caótica

Ótica futura

Samba -rap, chic-left com banana Será que ela está no Pão de Açúcar?

Tá craude brô você e tu lhe amo

Qué queu te faço, nego?

Bote ligeiro

[...]

Lívros, discos, vídeos à mancheia

E deixe que digam, que pensem e que falem

Caetano Veloso 


\subsection{Leitura e (não) leitores no Brasil}

Embora a escolaridade da população brasileira venha se elevando, de acordo com os dados fornecidos pelo Censo 2000/IBGE e pela PNAD 2006/IBGE, ainda é muito elevado o número de pessoas que não dominam a tecnologia da leitura e da escrita, cerca de 35 milhões ${ }^{3}$ :

\begin{tabular}{|l|c|r|}
\hline & 2000 & 2006 \\
\hline Analfabeto & 40.480 .015 & 35.532 .845 \\
\hline Sabe ler e escrever / Primário & 51.163 .211 & 56.236 .501 \\
\hline Ginásio / 8 ${ }^{\mathrm{a}}$. série & 39.111 .434 & 39.983 .221 \\
\hline Colegial/Ensino Médio & 28.785 .441 & 40.029 .959 \\
\hline Ensino Superior & 10.332 .754 & 15.441 .854 \\
\hline & 169.872 .855 & 187.224 .380 \\
\hline
\end{tabular}

Tabela 1: Escolarização da população brasileira.

Os dados sobre o alfabetismo no Brasil são ainda mais desalentadores que aqueles apontados pelo IBGE quando se tenta perceber a efetiva existência de práticas de leitura e escrita entre a população, ou seja, quando se leva em consideração o conceito de letramento. Esse é o caso do Indicador Nacional de Alfabetismo Funcional (INAF), instrumento desenvolvido pela parceria do Instituto Paulo Montenegro e de Ação Educativa. De acordo com a pesquisa INAF 2005 , apenas $26 \%$ da população brasileira adulta tem domínio pleno das habilidades de leitura e escrita, $7 \%$ da população adulta não é alfabetizada, $30 \%$ é alfabetizada rudimentar e $38 \%$ é alfabetizada básica.

Importante apontar a distinção já corrente que se faz entre alfabetização e letramento. Nas palavras de Magda Soares (1998, p. 40), alfabetização é a “ação de ensinar/aprender a ler e a escrever". Já letramento é o "estado ou condição de quem não apenas sabe ler e escrever, mas cultiva e exerce as práticas sociais que usam a escrita". Sendo assim, ser alfabetizado não é sinônimo de ser letrado: "alfabetizado é aquele que sabe ler e escrever; já o indivíduo letrado é aquele que usa socialmente a leitura e a escrita, pratica a leitura e a escrita, e responde adequadamente às demandas sociais de leitura e escrita". Ainda de acordo com Soares, não ser letrado corresponde a ser analfabeto funcional.

Magda Soares (1998) aponta como condições para o desenvolvimento de práticas de leitura e escrita a "escolarização real e efetiva da população" e a disponibilidade de material de leitura para que os alfabetizados fiquem "imersos em um ambiente de letramento". Todavia, em suas próprias palavras, o que ocorre em países como o Brasil

\footnotetext{
${ }^{3}$ Fonte: Retratos da Leitura no Brasil, 2008, $2^{\mathrm{a}}$. edição.
} 
é que se alfabetizam crianças e adultos, mas não lhes são dadas as condições para ler e escrever: não há material impresso posto à disposição, não há livrarias, o preço dos livros e até dos jornais e revistas é inacessível, há um número muito pequeno de bibliotecas (SOARES, 1998, p. 58).

O mais grave é que as bibliotecas escolares também são raras, em especial nas escolas públicas, justamente as que atendem às camadas populares. Além de raras, tais bibliotecas são precárias: possuem quase sempre um acervo pequeno e desatualizado (SOARES, 2004).

Quanto à presença de livrarias, Soares esclarece que a relação considerada minimamente adequada é de uma livraria para cada 6 a 8 mil habitantes. O Brasil deveria ter, portanto, cerca de 10.000 livrarias. Em 2001, contava, porém, com apenas $2.008^{4}$. E essas não estavam distribuídas de forma eqüitativa: em 1999, além de 64,5\% dos municípios brasileiros não terem nenhuma livraria, $78 \%$ delas concentravam-se nas regiões sudeste (56\%) e sul $(22 \%)^{5}$.

Baseada no Diagnóstico do Setor Editorial de 2000, da Câmara Brasileira do Livro, Soares apontou que, ainda que a indústria do livro tivesse crescido nos últimos anos, a tal crescimento não havia correspondido uma melhora das condições de possibilidade de consumo do livro, pois tinha havido um aumento no número de títulos, mas as tiragens haviam se tornado menores, o que encarecera o livro. Em 2000, a compra média de livros por adulto alfabetizado ${ }^{6}$ era de 1,21 livro por ano. Excluindo-se os didáticos, a compra média reduzia-se a 0,66 livro por ano (Ibid., p. 23).

Soares concorda com o relatório da $1^{\mathrm{a}}$. edição da pesquisa Retratos da Leitura no Brasil, o qual constata que a posse de livros "apresenta dinâmica idêntica à distribuição de renda no País, onde poucos têm muito e muitos têm pouco": 16\% da população adulta alfabetizada concentram 73\% dos exemplares comprados (2001, p. 36-41 apud SOARES, 2004, p. 24). Tal dinâmica é válida não apenas para a posse de livros, mas também para as condições de acesso à leitura: "há uma perversa relação entre a distribuição de renda no País e as condições de acesso à leitura, distribuição desigual quer se considerem as regiões do País, quer se considerem os estratos socioeconômicos da população”. Os obstáculos à

\footnotetext{
${ }^{4}$ Fonte: Anuário Editorial Brasileiro. São Paulo: Cone Sul, 2001 apud SOARES, 2004, p. 22.

${ }^{5}$ Fonte: Retratos da Leitura no Brasil, pesquisa conduzida de 10 de dezembro de 2000 a 25 de janeiro de 2001, pela Câmara Brasileira do Livro - CBL/Sindicato Nacional dos Editores de Livros-Snel/Associação Brasileira de Celulose e Papel - Bracelpa e Associação Brasileira de Editores de Livros-Abrelivros. (Câmara Brasileira do Livro, CDRom, apud SOARES, 2004, p. 22).

${ }^{6}$ Idade igual ou superior a 14 anos, com três anos de escolaridade, no mínimo.
} 
democratização da leitura são de natureza estrutural e econômica. Isso significa que "a distribuição eqüitativa do bem simbólico que é a leitura depende de mudanças que ultrapassam o educacional e o cultural" (SOARES, 2004, p. 23-25).

A 2a . edição da pesquisa Retratos da Leitura no Brasil, realizada em 2007, constitui o mais recente estudo quantitativo sobre o comportamento leitor em nosso país ${ }^{7}$. A metodologia e os indicadores da $1^{\mathrm{a}}$. e da $2^{\mathrm{a}}$. edições da pesquisa são diferentes, o que nem sempre permite uma comparação entre ambas. No entanto, é possível dizer que a análise de Soares continua válida, ou seja, que pouco mudou no quadro de obstáculos à democratização da leitura, configurando uma tendência de não formação de leitores nas camadas populares.

$\mathrm{Na}$ referida pesquisa, que se baseou nas auto-declarações dos entrevistados, foi considerado leitor quem afirmou ter lido ao menos um livro nos 3 meses anteriores à enquete, mesmo que o livro tivesse sido lido apenas parcialmente ${ }^{8}$. Foram considerados nãoalfabetizados $16 \%$ da amostra. O número de leitores auto-declarados foi 95,6 milhões (55\% da população estudada), contra 77,1 milhões de não leitores (45\% da população). Cinqüienta por cento dos leitores são estudantes que lêem livros indicados pelas escolas (incluindo os didáticos). Quase 7 milhões são leitores da Bíblia. Entre os outros 41,1 milhões de pessoas que não são estudantes, 14,9 milhões têm o Ensino Médio (37\% desse grupo de escolaridade) e 8,5 milhões têm Ensino Superior (55\% desse grupo de escolaridade). Já os não-leitores de livros têm baixa ou nenhuma escolaridade: $33 \%$ deles não são alfabetizados e 37\% estudaram até o $4^{\circ}$. ano do Ensino Fundamental. O número de não-leitores reduz-se em função do aumento da renda familiar e da elevação da classe social. Enquanto $60 \%$ dos não-leitores pertencem às classes $\mathrm{D}$ e E, praticamente inexistem não-leitores na classe $\mathrm{A}$ e há apenas $1 \%$ de não-leitores quando a renda familiar é superior a 10 salários mínimos, o que indica que o

\footnotetext{
${ }^{7}$ A $2^{\text {a }}$. edição da Retratos da Leitura no Brasil consistiu de uma pesquisa quantitativa de opinião com aplicação de questionário (com 60 questões) estruturado por meio de entrevistas presenciais (com duração média de 60 minutos), realizadas nos domicílios. A amostra definida representa todo o universo da população brasileira com 5 anos de idade ou mais, ou seja, quase 173 milhões de pessoas. Assim, todo o território nacional foi coberto com 5.012 entrevistas domiciliares em todas as unidades da federação. Inicialmente, foi definido um número de entrevistas proporcional ao tamanho de cada unidade federativa. Publicada em 2008, foi realizada em novembro e dezembro de 2007, pelo Instituto Pró-Livro, uma Organização Social Civil de Interesse Publico (OSCIP) mantida com recursos constituídos por contribuições de entidades do mercado editorial, com o objetivo principal de fomento à leitura e à difusão do livro. Foi criado em outubro de 2.006, como resultado de estudos e conversação entre representantes do governo e o Sindicato Nacional dos Editores de Livros (SNEL), a Câmara Brasileira do Livro (CBL) e a Associação Brasileira de Editores de Livros (ABRELIVROS).

${ }^{8}$ Considerando-se que os entrevistados tenderiam, em auto-declarações, a dar respostas socialmente mais valorizadas, supomos que o número de leitores seja menor que o declarado e que o número de não-leitores seja superior.
} 
poder aquisitivo é muito significativo para a constituição de leitores assíduos (CUNHA, 2008).

No Brasil, comprou-se 1,2 livro por habitante/ano, incluindo aqueles indicados pela escola. Apenas $21 \%$ da população estudada tinham adquirido pelo menos 1 livro no ano anterior à enquete.

\subsubsection{Acesso}

Os resultados da pesquisa evidenciam que "há uma grande, enorme fatia da população que não conhece os materiais de leitura, ou conhece muito mal. Há um claríssimo problema de acesso aos materiais de leitura, especialmente ao livro" (Ibid., p. 12). O número de livros lidos por ano foi 4,7 por habitante. Desses, 3,4 livros foram indicados pela escola (incluindo os didáticos). O número de livros lidos fora da escola foi de apenas 1,3 por habitante/ano.

A todos os pesquisados - e não apenas aos leitores -, perguntou-se se tinham livros em casa. $85 \%$ da população estudada afirmou possuir pelo menos um livro. A média de livros na casa das pessoas é 25. Dentre eles, 12,6 são livros indicados pela escola (inclusive didáticos), 2 são a Bíblia, 3 são livros religiosos, e apenas 4 livros são outros livros. Tais dados são reveladores da grande importância da escola e do livro didático como fonte de material impresso, tão mais importante quanto mais baixa for a classe social.

A pesquisa também evidenciou a extrema desigualdade na distribuição dos livros: $19 \%$ deles estão nas mãos de $1 \%$ da população e $49 \%$ desses mesmos livros pertencem a $10 \%$ da população. Essa desigualdade é ainda mais perversa quando se considera que 3 em cada 4 brasileiros não têm o hábito de ir a bibliotecas. A pesquisa mostra que muitos dos entrevistados desconhecem esse equipamento no seu bairro ou na cidade. Segundo informação de 2005 do Ministério da Cultura, quase 90\% dos municípios brasileiros têm pelo menos uma biblioteca. Porém, apenas $66 \%$ dos pesquisados confirmaram essa informação e somente $10 \%$ dos entrevistados freqüentam esse espaço com assiduidade.

Os leitores que freqüentam bibliotecas o fazem apenas durante a vida escolar e, ainda assim, 46\% dos estudantes não têm esse hábito. Apenas 1 em cada 4 estudantes freqüenta bibliotecas públicas municipais. O uso de bibliotecas reduz-se progressivamente com o encerramento da vida escolar, caindo de $62 \%$ dos leitores adolescentes para $20 \%$ na idade adulta e $12 \%$ em torno dos 50 anos.

Os leitores declararam que as principais formas de acesso aos livros foram empréstimos por outras pessoas (45\%), compra (45\%) e empréstimos por bibliotecas (34\%), 
entre outras ${ }^{9}$. Talvez a escola seja o serviço público com maior taxa de cobertura no Brasil. Sendo assim, faz sentido supor que a principal forma de acesso aos livros deveria ser justamente a biblioteca escolar. Ora, o fato de os empréstimos por bibliotecas aparecerem em terceiro lugar entre as formas de acesso aos livros é bastante negativo: é provavelmente sintoma da inexistência de bibliotecas públicas suficientes e é também sinal de que as bibliotecas escolares não funcionam a contento.

A pesquisa Retratos da Leitura no Brasil apontou também diferenças importantes nas formas de acesso aos livros de acordo com a classe social ${ }^{10}$ :

\begin{tabular}{|l|c|c|c|c|c|}
\hline Livros & Classe & Classe & Classe & Classe & Classe \\
& $A$ & $B$ & $C$ & $D$ & $E$ \\
\hline Comprados & $73 \%$ & $65 \%$ & $48 \%$ & $32 \%$ & $27 \%$ \\
\hline Emprestados por bibliotecas (inclusive escolares) & $24 \%$ & $31 \%$ & $37 \%$ & $33 \%$ & $22 \%$ \\
\hline Emprestados por particulares & $35 \%$ & $47 \%$ & $46 \%$ & $44 \%$ & $49 \%$ \\
\hline Distribuídos pelo governo e/ou escolas & $3 \%$ & $11 \%$ & $15 \%$ & $29 \%$ & $40 \%$ \\
\hline Baixados gratuitamente da Internet & $10 \%$ & $13 \%$ & $9 \%$ & $3 \%$ & $3 \%$ \\
\hline
\end{tabular}

Tabela 2: Formas de acesso aos livros.

A análise da tabela acima suscita algumas reflexões. Primeiramente, fica bastante evidenciada a importância da garantia de acesso a livros pelo Estado para a classe E, já que $40 \%$ de seus livros são distribuídos pelo governo e/ou escolas e apenas 3\% são comprados. Em segundo lugar, ironicamente, os empréstimos em bibliotecas são mais freqüentes em todas as classes sociais do que na $\mathrm{E}$, a qual é a que menos tem acesso aos livros por aquisição. Embora os empréstimos por particulares cresçam nessa mesma classe, isso não é motivo de júbilo, porque, em tese, os amigos e colegas que podem emprestar livros pertenceriam à mesma classe social e não disporiam, portanto, de muito material impresso.

\subsubsection{Penetração da leitura}

Continuando a análise dos dados da $2^{\mathrm{a}}$. edição da pesquisa Retratos da Leitura no Brasil, é interessante ressaltar que, quando questionados sobre o que gostavam de fazer no seu tempo livre, apenas $24 \%$ do total de pesquisados (leitores e não-leitores) incluíram ler como uma opção de atividade $^{11}$. A preferência pela leitura aumenta com a renda e a escolaridade:

\footnotetext{
${ }^{9}$ Resposta estimulada em que se podia escolher várias opções.

${ }^{10}$ Idem.

${ }^{11}$ Nessa questão, o ato de ler referia-se a qualquer suporte e não só a livros.
} 
para $48 \%$ no Ensino Médio e $64 \%$ no Superior. Entre quem recebe mais de 10 salários mínimos, ela chega a $67 \%$.

O perfil dos leitores que afirmaram gostar de ler (não apenas livros, mas também jornais, revistas e outros suportes) em seu tempo livre e fazer isso com freqüência é o seguinte: formação superior (79\%), renda familiar acima de 10 salários mínimos (78\%), membros das classes A (75\%) e B (74\%), jovens e adultos de 18 a 24 anos (67\%) e 30 a 39 (68\%). Entre os leitores de livros, apenas um terço afirmou ler freqüentemente e, entre eles, $55 \%$ são mulheres. Na região Sudeste, entre os leitores que declararam gostar de ler, $71 \%$ disseram ler com freqüência. Dentre os que afirmaram ler com freqüência, 79\% têm ensino superior e $74 \%$ pertencem às classes $\mathrm{A} / \mathrm{B}$.

De modo geral, o tempo dedicado à leitura de livros é impressionantemente baixo $51 \%$ dos leitores de livros lêem-nos de 1 a 3 horas por semana - mas ele cresce em função da escolaridade do leitor.

Os dados sobre a taxa de penetração da leitura por grau de instrução mostram o aumento crescente do percentual de leitores conforme avançam na escolarização e a maior penetração de livros em geral (92\%) e de livros não indicados pela escola (57\%) entre os leitores que concluíram o ensino superior:

\begin{tabular}{|l|c|c|c|c|}
\hline & $\begin{array}{c}\text { Até } 4^{a} . \\
\text { série E.F. }\end{array}$ & $\begin{array}{c}5^{a} \text {. à } 8^{a} . \\
\text { série E. } F .\end{array}$ & $\begin{array}{c}\text { Ensino } \\
\text { Médio }\end{array}$ & $\begin{array}{c}\text { Ensino } \\
\text { Superior }\end{array}$ \\
\hline Leitores de livros em geral & $37 \%$ & $68 \%$ & $64 \%$ & $92 \%$ \\
\hline $\begin{array}{l}\text { Leitores de livros indicados } \\
\text { pela escola }\end{array}$ & $24 \%$ & $36 \%$ & $23 \%$ & $35 \%$ \\
\hline $\begin{array}{l}\text { Leitores de livros não } \\
\text { indicados pela escola }\end{array}$ & $13 \%$ & $32 \%$ & $41 \%$ & $57 \%$ \\
\hline
\end{tabular}

Os dados sobre a taxa de penetração da leitura por classe social evidenciam a enorme disparidade no desenvolvimento de práticas de leitura para além daquelas solicitadas pela escola, em especial quando se comparam os números sobre leitores de livros em geral (86\%) e leitores de livros não indicados pela escola (56\%) na classe A aos números das classes D/E: a $44 \%$ e $20 \%$ dos leitores, respectivamente: 


\begin{tabular}{|l|c|c|c|c|}
\hline & Classe A & Classe B & Classe C & $\begin{array}{c}\text { Classes } \\
\text { D/E }\end{array}$ \\
\hline Leitores de livros em geral & $86 \%$ & $74 \%$ & $61 \%$ & $44 \%$ \\
\hline $\begin{array}{l}\text { Leitores de livros indicados } \\
\text { pela escola }\end{array}$ & $30 \%$ & $31 \%$ & $30 \%$ & $24 \%$ \\
\hline $\begin{array}{l}\text { Leitores de livros não } \\
\text { indicados pela escola }\end{array}$ & $56 \%$ & $43 \%$ & $31 \%$ & $20 \%$ \\
\hline
\end{tabular}

Tabela 4: Taxa de penetração da leitura por classe social.

\subsubsection{Formação de leitores: a família e a escola}

Ainda no âmbito da $2^{\text {a }}$. edição da Retratos da Leitura no Brasil, quando questionados sobre quem mais os influenciou a ler, $49 \%$ dos leitores apontaram a mãe ou responsável mulher, 33\% deles indicaram a professora, 30\% mencionaram o pai ou responsável homem, $14 \%$, outro parente e apenas $8 \%$ se referiram a um amigo ${ }^{12}$. Tais dados sinalizam a relevância do papel exercido pela família e, em segundo lugar, pela escola, na formação de leitores, em comparação com o grupo de pares $(8 \%)$ e as instituições religiosas $(5 \%)$.

Enquanto $60 \%$ dos leitores costumavam ver os pais lendo em casa, no caso dos nãoleitores, 55\% nunca presenciaram atos de leitura entre os familiares. Concordo com Cunha (2008), quando afirma que, se se considerar, conforme afirmaram os leitores, que a maior influência para a formação deles veio dos pais (principalmente das mães), sujeitos das classes de menor poder aquisitivo e menor escolaridade terão menos probabilidade de se tornarem leitores. De fato, os pais e mães dos sujeitos não-leitores não têm escolarização alguma (23\% e $26 \%$, respectivamente), estudaram até a $4^{\mathrm{a}}$. série do Ensino Fundamental (23\% e 22\%) ou têm Fundamental incompleto (15\% e 16\%). Em tal contexto, é justo supor que a escola assume um papel tão mais importante para o letramento quanto mais desfavorecida for a classe social do sujeito.

Mas tem a escola se mostrado preparada para exercer a contento esse papel de agência privilegiada de letramento das camadas populares? Aparentemente, não. Conforme analisa Cunha (2008), as dificuldades de leitura declaradas pelos entrevistados alfabetizados (leitores e não-leitores) são indício da má formação das habilidades necessárias à leitura, a qual se deve à tão conhecida fragilidade do processo educacional ${ }^{13}$ :

\footnotetext{
${ }^{12}$ Pergunta feita apenas aos leitores que disseram gostar de ler. Resposta estimulada em que se podia escolher duas alternativas.

${ }^{13}$ Pergunta feita a todos os entrevistados, com resposta estimulada em que podiam escolher várias opções.
} 


\begin{tabular}{|l|c|}
\hline Dificuldades de leitura & \\
\hline Lê muito devagar & $17 \%$ \\
\hline Não compreende o que lê & $7 \%$ \\
\hline Não tem paciência para ler & $11 \%$ \\
\hline Não tem concentração & $7 \%$ \\
\hline
\end{tabular}

Tabela 5: dificuldades de leitura declaradas pelos entrevistados alfabetizados

Ainda assim, ao analisar a taxa de penetração da leitura por idade, percebe-se o quanto o desenvolvimento de práticas de leitura está, em especial na infância e na adolescência, muito vinculado à freqüência à escola. Dos 5 aos 17 anos, entre 60 e $70 \%$ dos leitores de livros leram majoritariamente obras indicadas pela escola:

\begin{tabular}{|l|c|c|c|c|c|}
\hline & $5 a 10$ & $11 a 13$ & $14 a 17$ & $18 a 24$ & $25 a 29$ \\
\hline Leitores de livros em geral & $67 \%$ & $85 \%$ & $82 \%$ & $61 \%$ & $52 \%$ \\
\hline $\begin{array}{l}\text { Leitores de livros indicados } \\
\text { pela escola }\end{array}$ & $60 \%$ & $73 \%$ & $63 \%$ & $26 \%$ & $19 \%$ \\
\hline $\begin{array}{l}\text { Leitores de livros não } \\
\text { indicados pela escola }\end{array}$ & $7 \%$ & $12 \%$ & $19 \%$ & $35 \%$ & $33 \%$ \\
\hline
\end{tabular}

Tabela 6: Taxa de penetração da leitura por idade.

A infância e a adolescência são lembradas pelos leitores como o período em que mais leram na vida, o que também denota que as práticas de leitura estão muito ligadas à escolarização. Se, por um lado, é auspicioso que estar na escola leve a ler, por outro, é preocupante que encerrar os estudos conduza à não leitura. Conforme alerta Cunha, há provavelmente um problema nas práticas de leitura promovidas no âmbito da escola:

visto que, a não ser entre os entrevistados que fizeram ou fazem estudos universitários, a leitura decresce muito entre os adultos, podemos supor que a escola não tem formado leitores para a vida inteira, talvez por práticas pouco sedutoras e obrigatórias, das quais o não estudante procura se livrar assim que ultrapassa os limites da escola (2008, p. 14-15).

Muitos entrevistados declararam não ler e não ir a bibliotecas por não estarem estudando, o que evidencia a ligação da leitura com a escola na percepção das pessoas. O uso da biblioteca pública parece também estar estritamente vinculado ao atendimento de demandas escolares.

À guisa de conclusão, é justo dizer que os dados apresentados acima indicam como os obstáculos à democratização do acesso à leitura continuam muito presentes, configurando 
uma tendência de não formação de leitores nas camadas populares, tendência essa tão mais acentuada quanto mais baixa for a classe social do sujeito. Se essa tendência é tão evidente quando se fala da leitura de modo geral, ela se fortalece ainda mais quando se pensa na formação de leitores de literatura, algo que será objeto de reflexão no capítulo 2.

Antes de prosseguir, porém, cabe-me delimitar a que literatura me refiro.

\subsection{A leitura literária e uma acepção de literatura}

Desnecessário dizer que a "leitura não é a ascese imediata às idéias puras, mas uma designação genérica de práticas bem diversificadas" (MANUKATA, 1999, p. 577). Tampouco é preciso retomar as idéias centrais na historiografia da leitura: as práticas de leitura "efetivam-se num quadro de determinações (sociais, econômicas, políticas, culturais, lingüísticas, etc.) que estabelecem limites ao que se denomina ali 'leitura" e "no universo assim delimitado, são possíveis escolhas múltiplas, de que resulta a produção de uma série particular de significações" (Idem) ${ }^{14}$.

O substantivo leitura é polissêmico, assim como o é o verbo ler, que, transitivo direto, aceita uma multiplicidade de complementos (SOARES, 2004). Interessou-me investigar a questão da leitura literária. Mas o que quero dizer exatamente com o adjetivo literária? Para responder tal questão, foi necessário que me embrenhasse na polêmica sobre as diferentes acepções de literatura.

A pergunta sobre o que é literatura persiste há pelo menos 25 séculos, desde Aristóteles, e continua a provocar reflexões (ZILBERMAN, 2001). Para vários estudiosos, dentre os quais estão Abreu (1999, 2000, 2004) e Lajolo (2001, 2003), “literatura não tem uma definição [...]. Há várias respostas" (LAJOLO, 2001, p. 24-25). Concordo com a autora quando lembra que, em cada época e em cada grupo social, as acepções de literatura e os sentidos atribuídos ao literário variaram. Além disso, escritores e críticos nem sempre concordaram, assim como os leitores nem sempre escolheram os modelos canônicos de literatura. Lajolo alerta ainda contra a crença na imanência da qualidade literária e chama a atenção para o poder simbólico e o capital cultural que classificações como "clássicos da literatura" carregam. Em suas palavras:

\footnotetext{
${ }^{14}$ Referência ao conjunto das obras de Roger Chartier e Robert Darnton.
} 
existem estudos de teoria literária sugerindo que o estabelecimento de certas obras como clássicas e de outras como não clássicas é uma questão de poder que pouco tem a ver com critérios estéticos [...], que envolvem questões de prestígio social, de capital cultural, de poder simbólico. [...] A gente costuma dizer que as classes populares têm direito de ler James Joyce e Guimarães Rosa, mas poderíamos perguntar: por que as classes populares têm de ler James Joyce e Guimarães Rosa? Ler estes senhores é um direito ou um dever? Respondemos simploriamente a questão dizendo: porque tais autores são melhores que outros, por exemplo, melhores que Paulo Coelho ou Zíbia Gasparetto. Mas quem disse que eles são melhores? A crítica literária. E quem é a crítica literária? São pessoas que tiveram uma determinada formação, que vêm de uma determinada classe social e que têm por profissão discriminar o melhor do pior, o bom do mau. Porém, hoje correntes muito respeitáveis dos estudos da linguagem afirmam que não existe modalidade de língua melhor ou pior. A pessoa que não faz concordância verbal, que diz "nós foi" ou "nós vai", é capaz de explicar um pensamento com a mesma sofisticação de quem diz "nós vamos" ou "nós fomos". E se aplicarmos à literatura esse pressuposto da língua? Ou seja, não podemos postular que não há formas melhores ou piores de literatura, mas que há apenas formas diferentes, e cada uma delas é eficiente no meio pelo qual circula? Se pensarmos assim, vamos subverter toda a noção de clássicos de literatura (LAJOLO, 2003, p.49).

Embora concorde que as camadas populares não têm de ler os clássicos, acredito que os sujeitos de tais camadas devem ter o direito de escolher ler ou não tais obras. Para tanto, é preciso que a mediação dessas obras seja feita por um leitor mais experiente. No caso das crianças e jovens das camadas populares, em tese, o âmbito privilegiado em que tal mediação deveria ocorrer é justamente a escola, e o leitor mais experiente deveria ser o professor.

Quanto à questão da linguagem (ou, em outras palavras, à opção pelo emprego de "nós vai" ou "nós vamos"), apesar de obviamente devermos, por um lado, evitar o preconceito lingüístico e a violência simbólica presentes na imposição da chamada norma culta da língua, não podemos, por outro lado, abdicar de ensinar a norma legitimada pela sociedade em que estamos inseridos. Como tal sociedade hierarquiza, sim, as formas lingüísticas, não podemos deixar de garantir aos sujeitos a possibilidade de transitar entre as normas, de acordo com a situação em que se encontrem. Ou seja, não podemos deixar de dar ao sujeito a opção de dizer "nós vai" no âmbito de sua família ou de seus amigos, se assim o desejar, e de dizer "nós vamos" no ambiente de trabalho, por exemplo, se assim o julgar adequado. Pensando dessa forma, deixar de mediar a norma culta pode se configurar também como uma forma de perpetuar a submissão do sujeito à violência simbólica dessa mesma norma.

Do mesmo modo, embora se possa postular que há formas diferentes de literatura e que não se deve classificá-las como melhores ou piores, é inegável que sociedade valoriza determinados bens culturais em detrimento de outros. Para a plena inserção do sujeito na 
cultura letrada e no cotidiano dessa sociedade, é essencial que ele tenha acesso aos bens culturais valorizados pela sociedade em que vive, o que inclui os clássicos da literatura. Isso de maneira alguma quer dizer que me alio a posições extremamente conservadoras, como aquelas adotadas pelos senhores que Lajolo (2001) espirituosamente chama "resmungões", que teimam em desconsiderar as qualidades literárias presentes em várias formas de expressão, como a música popular, por exemplo, e em suportes para além do livro. Daí a epígrafe deste capítulo.

Ora, uma leitura superficial do raciocínio de Lajolo no trecho supracitado poderia levar a supor que a autora se opusesse à inclusão dos chamados "clássicos da literatura" no currículo escolar. Nada disso, porém. Justamente em função do valor político e simbólico de que os clássicos desfrutam, Lajolo acredita que a todos deve ser franqueado o acesso às e a mediação das obras consagradas:

a escola precisa, de alguma maneira, oferecer ao aluno acesso a essa moeda de trânsito social - a literatura canônica - mas sem fazer crer que a canonicidade (ou o valor estético, ou o valor literário) é imanente. Entendo que reconhecer ou apreciar o valor estético das obras-primas é sinal de distinção social, como o é utilizar corretamente as normas da concordância verbal. É assim - como moeda de trânsito social - que todos precisam ter acesso aos instrumentos pelos quais se aprende a reconhecer e a eventualmente apreciar esse tipo de obra consagrada pela crítica (2003, p.49).

A discussão sobre o caráter histórico e, portanto, arbitrário da seleção feita pelo cânone e da necessidade de respeitar as "variadas formas de ler" (LAJOLO, 2001, 2003; ABREU, 1999, 2000, 2004) tem influenciado as recomendações de leitura feitas pela escola, o que é, em opinião, bastante positivo. Há hoje uma maior diversidade no acervo de livros que circula pela escola, o que aumenta as chances de que as crianças descubram seus livros e seus tipos de leitura favoritos (LAJOLO, 2003).

Em interessante artigo em que reflete justamente sobre as escolhas dos livros que se pede às crianças e jovens que leiam, Magda Soares, em diálogo com os defensores da diversidade, mas sem se alinhar a posições conservadoras, propõe uma acepção de literatura com a qual concordo, que adotei em minha pesquisa e que apelidei de "nem tanto ao mar, nem tanto à terra", num elogio ao equilíbrio do posicionamento da autora. Ela defende que, embora haja variações sobre o que se considera literatura no tempo e entre diferentes sujeitos, as obras que vencem o tempo e as diferenças de opiniões compõem o que se chama literatura: 
afirmo, sem me deter em discussões conceituais, e mesmo reconhecendo que há posições contrárias - há os que defendem que todo o texto é literatura, há os que defendem que literatura é o que se caracteriza como sendo literatura mesmo reconhecendo essas e outras posições contrárias, afirmo minha posição de que há, sim, um corpo de livros e textos que são literatura, que constituem o campo literário, e que se distinguem inequivocamente de outros livros e textos que não podem ser considerados literatura. Assumindo a tendência atual de tomar a evidência como prova da existência, não se pode negar que há obras que, em meio a tudo que foi escrito, foram e são preservadas, vencem o tempo e os modismos e as chamadas "escolas literárias" - estas obras são literatura; e também não se pode negar que, ainda que gostos e preferências variem, há um consenso sobre as obras que pertencem ao campo literário: críticos, escritores, pesquisadores podem divergir sobre "os melhores romances mundiais", "os melhores escritores brasileiros", como acontece sempre nas enquetes e eleições promovidas pela mídia, mas nunca dirão que livros que constam de outras listas e estão ausentes da sua não são literatura. Há preferências, mas não há desacordo sobre que obras têm o status de literárias. (SOARES, no prelo, p. 2, grifos meus)

Novamente ao contrário do que se poderia supor, a proposta feita por Soares da existência de um campo literário e de um conjunto de obras que são literatura de modo algum significa que a autora se oponha à oferta de uma gama diversificada de leituras. Ao contrário, ela sugere

duas alternativas para a formação de leitores, crianças e jovens: de um lado, a leitura de entretenimento, em que a regra principal da escolha seja o critério do prazer, embora sem abandonar o critério do literário; de outro lado, a leitura de clássicos, em que a regra da escolha é a necessidade de conhecimentos literários que se incorporaram à cultura e à linguagem (Ibid. p. 2, grifos meus).

Acompanhemos o caminho trilhado por Soares para chegar a essa recomendação. Em primeiro lugar, a autora propõe, segunda ela própria com alto grau de simplificação, que há três tipos fundamentais de leitura: a funcional, a de entretenimento e a literária. Os três tipos não são excludentes e a diferença fundamental entre elas não se deve ao texto em si, mas a quem lê, para que lê e, por conseguinte, ao modo de ler. A leitura funcional é aquela que se faz para obter informações e conhecimentos necessários nas sociedades grafocêntricas, para que participemos plenamente dos eventos de letramento da vida cotidiana e profissional. A leitura de entretenimento é aquela que representa uma forma de lazer, a qual se faz "em busca de prazer, que traz satisfação emocional, identificações, ampliação do horizonte pessoal para outros mundos e outros seres humanos" (SOARES, no prelo, p. 4). A leitura literária, por sua vez, é aquela que: 
questiona a significação, que busca o sentido, que persegue o valor mutante e mutável da palavra, que é dirigida pelo estético, que despreza o literal e valoriza o subjacente, o implícito, que identifica originalidades e se surpreende com a força criativa, que surpreende no texto a condição humana (Ibid., p. 4).

Todos precisamos da leitura funcional. Já a leitura de entretenimento é realizada pelas pessoas que encontram prazer no livro a ponto de dedicarem também a ele - e apenas não ao mundo midiático, esportivo ou da sociabilidade - suas horas de lazer. A leitura literária é hoje e foi sempre "um modo de ler minoritário", de uma elite e Soares não acredita que seja exequível fazer de todos os jovens leitores literários ${ }^{15}$.

A autora sugere que, por um lado, o critério fundamental nas escolhas de livros para oferecer às crianças e jovens seja seu poder de atração e sedução, para favorecer a formação de leitores. Mas alerta que, ao admitir que se considere como critério principal para as escolhas de livros o seu poder de entretenimento, não se pode menosprezar a qualidade literária:

se a leitura de entretenimento, que pode inserir a criança e o jovem no mundo dos livros pela via da descoberta do prazer de ler, for também leitura de livro literário, embora não se possa pretender da criança ou do jovem um modo de ler literário, uma leitura autenticamente e plenamente literária, pode-se propiciar-lhes a vivência do que é literatura, uma percepção, não reconhecida que seja, do que é literário no texto (Ibid., p. 7).

Soares propõe também um segundo critério: "que, independentemente de sua possibilidade de constituir entretenimento, aqueles livros chamados 'clássicos' sejam objeto de uma das regras do jogo de escolhas para crianças e jovens - leituras necessárias”. Com Harold Bloom, Soares define os clássicos como "o que se preservou do que se escreveu”. Mas explica "o que se preservou" não apenas segundo o critério estético, mas também pelo "poder de criação de personagens, ações, frases, conceitos tão significativos, tão fortes que se incorporaram como metáforas à cultura, à linguagem", em um "quase infinito jogo de intertextualidades" (SOARES, no prelo, p. 11).

A autora defende que se inclua entre os livros propostos às crianças e jovens

clássicos entendidos não propriamente como obras que propiciem entretenimento, mas fundamentalmente como obras que é preciso conhecer [...] porque permitem a plena compreensão de referências intertextuais, de

\footnotetext{
15 Soares reitera que os três tipos de leitura não são excludentes. Afinal, a leitura funcional pode oferecer prazer e ser feita em horas de lazer. Da mesma forma, o texto de entretenimento também fornece ao leitor informações e conhecimentos. E o texto literário também pode ser fonte de entretenimento ou suscitar uma leitura funcional, como quando a literatura é tomada como fonte para estudos históricos.
} 
metáforas que circulam no discurso cotidiano, nos jornais, nas revistas, nos próprios livros lidos por prazer ou como lazer (SOARES, no prelo, p. 11).

Mas se as crianças e jovens não estão maduros o suficiente para ler os clássicos, como acredita Calvino (1993), Soares sugere o apelo às adaptações, ainda que muito do aspecto literário nelas se perca, já que o objetivo é "desenvolver conhecimentos que fazem parte da cultura letrada em que pretendemos inserir crianças e jovens". Assim, um jovem não corre o risco de não saber a que nos referimos

quando dizemos que alguém é um Dom Quixote, ou que uma atitude é
quixotesca; quando ameaçamos um nariz de crescer, ao desconfiar de uma
mentira, aludindo a Pinóquio, sem o mencionar; [...] quando dizemos que
uma viagem foi uma odisséia; quando qualificamos algo como nosso
calcanhar de Aquiles; quando, diante de um atraso, dizemos agora é tarde,
Inês é morta; ou quando, diante de uma dúvida, repetimos ser ou não ser, eis
a questão; [...] quando caracterizamos uma situação como kafkiana... (Idem).

Conforme disse antes, alinho-me com o posicionamento de Soares sobre o que seja literatura e leitura literária. A adoção de ambos os conceitos contribui para circunscrever o que quero dizer com eles no âmbito de minha pesquisa. De qualquer modo, independentemente da posição que se assuma, tanto Lajolo quanto Soares têm argumentos em favor da inclusão de obras clássicas da literatura no currículo escolar: o dever de oferecer ao aluno acesso a uma "moeda de trânsito social" (LAJOLO, 2003) e o desenvolvimento de conhecimentos da literatura legitimada por uma determinada sociedade para se compreender e participar ativamente da intertextualidade dos discursos que permeiam o cotidiano (SOARES, no prelo). Ora, se dizemos que a escola deve favorecer o ensino de literatura, justifica-se pesquisar quão bem-sucedida (ou não) a escola tem sido na apresentação e mediação de tal saber.

Além disso, se o Ensino Médio tem sido o período em que se privilegia o trabalho com a literatura brasileira clássica, até em função da perspectiva do vestibular, independentemente de se criticar ou aderir a essa escolha curricular e às escolhas das universidades quanto ao conteúdo de suas provas de ingresso, novamente justifica-se investigar qual foi a atuação da escola para a formação de leitores desse tipo de literatura.

O terceiro motivo, já parcialmente apresentado, é minha crença no direito que as pessoas têm de escolher o tipo de obra que querem (ou não) ler, uma vez que lhes tenha sido apresentada uma variada gama de textos. Não se pode alijar crianças e jovens das camadas populares da possibilidade de se formarem leitores literários, e até leitores literários que incluem em seu leque de leituras também obras consagradas da literatura. Alijá-los desse tipo 
de possibilidade seria também uma forma de violência, comparável a supor que não valha a pena expor alunos de uma escola na favela a música instrumental em nome do respeito a formas de expressão musical mais comuns nesse espaço, como o samba ou o rap, imaginar que o esportista Tiger Woods deveria jogar basquete e não golf, por ser este um jogo tradicionalmente praticado por uma elite branca, ou que a crianças de meios iletrados não faria sentido ensinar filosofia porque eles provavelmente não a empregariam em suas ocupações futuras. Seria também ignorar e até desfavorecer a possibilidade de "circularidade entre a cultura erudita e a popular" (GINZBURG, 2006).

O quarto e último motivo que me leva a querer investigar como se dá a mediação da literatura, está estritamente vinculado ao papel privilegiado que a linguagem tem na constituição das funções psíquicas caracteristicamente humanas, conforme explorarei no tópico a seguir.

\subsection{Pensamento e linguagem na perspectiva de Vygotsky}

A linguagem - em especial a língua - tem papel essencial na concepção vygotskiana de desenvolvimento humano, segundo a qual "o pensamento não é simplesmente expresso em palavras; é por meio delas que ele passa a existir" (VYGOTSKY, 1989, p. 108). Vygotsky discute duas funções básicas da linguagem: o intercâmbio social e o pensamento generalizante. A necessidade de comunicação entre os seres humanos impulsiona o desenvolvimento da linguagem e, como cada pessoa vive experiências particulares, o real tem de ser simplificado e generalizado para ser traduzido em signos compreendidos por todos. A função generalizante "torna a linguagem um instrumento de pensamento", pois "fornece os conceitos e formas de organização do real que constituem a mediação entre o sujeito e o objeto do conhecimento"16 (OLIVEIRA, 1993, p. 43) e, ao usar a linguagem, o homem pensa por generalizações e abstrações que não seriam possíveis sem ela.

\footnotetext{
16 Até que aconteça a ligação entre eles, pensamento e a linguagem têm origens e trajetórias diferentes tanto na filogênese (história da espécie) quanto na ontogênese (história de cada indivíduo). Nos primatas, Vygotsky percebeu formas precursoras do pensamento e da linguagem do homem - a "fase pré-verbal do desenvolvimento do pensamento" e a "fase pré-intelectual do desenvolvimento da linguagem" - e uma espécie de "inteligência prática" (a capacidade de solucionar problemas e de alterar o ambiente), a qual independe da linguagem. E, apesar de os animais também terem uma linguagem própria, ela não pode ser comparada à humana, pois é préintelectual, já que não tem função de signo. Existe, assim, a trajetória do pensamento separado da linguagem e a trajetória da linguagem separada do pensamento. Num momento da história filogenética, as duas trajetórias se encontram e o pensamento passa a ser verbal e a linguagem, racional. $\mathrm{O}$ aparecimento do pensamento verbal e da linguagem como um sistema de signos é um marco na espécie humana, em que o biológico torna-se sócio-
} 
O significado, elemento fundamental da palavra, é também um ato de pensamento, já que é uma generalização. No significado, o pensamento e a fala se unem em pensamento verbal. Também no significado está a união das duas funções da linguagem - o intercâmbio social e o pensamento generalizante. Na história de uma língua, o significado está sempre se transformando. Também há transformação do significado na aquisição da linguagem pela criança. Primeiro, ela aplica os significados a seu conhecimento sobre o mundo, a sua forma de "recortar" o real e, durante seu desenvolvimento, graças à interação com pessoas mais maduras, a criança ajusta os significados, aproximando-os dos conceitos de seu grupo cultural e lingüístico. Essa transformação dos significados continua durante todo o desenvolvimento do indivíduo, em especial durante o processo de aprendizagem escolar, em que há intervenção deliberada, em que as transformações partem dos diferentes sistemas conceituais das diferentes disciplinas científicas (OLIVEIRA, 1993).

Os diferentes autores da corrente sócio-histórica (VYGOTSKY, 1987; LEONTIEV, 1978; LURIA, 1987) dividem o significado em significado propriamente dito e o sentido. Compreende-se por significado a significação convencional atribuída aos signos pela sociedade. Por sentido, entende-se a significação que esses signos têm para cada pessoa, influenciada pelo contexto de uso da palavra e pelas vivências afetivas ${ }^{17}$.

Para Vygotsky, há diferenças qualitativas entre as emoções dos animais e dos homens, assim como entre crianças e adultos: os seres humanos têm emoções mais sofisticadas que os animais; e os adultos têm emoções mais refinadas que as crianças. $\mathrm{O}$ autor distingue as emoções primitivas originais (alegria, medo, raiva etc.) das superiores complexas (respeito, melancolia etc). A qualidade das emoções se modifica à medida que a criança desenvolve conhecimento conceitual e processos cognitivos (OLIVEIRA; REGO, 2003).

histórico. Na história de cada indivíduo, acontece um processo similar àquele da espécie. Também na criança pequena há uma fase pré-verbal no desenvolvimento do pensamento e uma fase pré-intelectual no desenvolvimento da linguagem. A criança também demonstra inteligência prática, com a qual ela atua sem a mediação da linguagem. Nessa fase, a criança tem manifestações verbais (choro, riso, balbucio) sem o domínio do sistema simbólico. Por volta dos dois anos, "o percurso do pensamento encontra-se com o da linguagem e inicia-se uma nova fase de funcionamento psicológico: a fala torna-se intelectual, com função simbólica, generalizante, e o pensamento torna-se verbal, mediado por significados dados pela linguagem" (OLIVEIRA, 1993). Na ontogênese, o impulso para a vinculação dos processos de pensamento e linguagem é dado pela inserção da criança num grupo cultural, que provoca o salto de qualidade para o pensamento verbal. $O$ ser humano passa a ter um modo de funcionamento psicológico mais sofisticado, mediado pelo sistema simbólico da linguagem e o pensamento verbal passa a predominar na ação psicológica tipicamente humana.

\footnotetext{
${ }^{17}$ Assim, a palavra carro, por exemplo, pode ter sentidos extremamente diversos para alguém que, tendo tirado sua carteira de habilitação recentemente, anseia por comprar seu primeiro carro; para um motorista de táxi que o usa dia após dia no trabalho; para o pedestre que tenha sofrido um atropelamento e para o urbanista ou ecólogo que defendem o uso de transporte coletivo não poluente.
} 
Se nas emoções primitivas está nítida a raiz instintiva, ao longo do desenvolvimento, as emoções se afastam de sua origem biológica e se tornam um fenômeno histórico e cultural. As mudanças qualitativas das emoções estão ligadas ao aumento do controle do homem sobre si mesmo, graças à razão, a qual controla os impulsos emocionais no homem cultural adulto. Mas a razão não exerce papel repressor, capaz de suprimir afetos. Pelo contrário, com o desenvolvimento, a razão fica a serviço da vida afetiva, pois é um instrumento de elaboração e refinamento dos sentimentos. É por isso que o adulto tem um universo emocional complexo e sofisticado e não ausência de emoções.

Nesse processo, é a linguagem que fornece aos indivíduos um conjunto de categorias para definir seus conteúdos. Assim, nunca vivenciamos os sentimentos de maneira pura: “A forma de pensar [...] inclui também nossos sentimentos [...]. O fato de nomear os sentimentos faz com que estes variem, já que guardam certa relação com nossos pensamentos." (VYGOTSKY, 1991, p. 86-7). Embora o nascimento da vida afetiva seja mediado pelos significados construídos no contexto cultural em que o indivíduo está, tal processo não é homogêneo, pois cada indivíduo lida de maneira singular com as mesmas influências (OLIVEIRA; REGO, 2003).

Em resumo, "o ser humano aprende, por meio de sua cultura e da interação com outros humanos, a agir, a pensar, a falar e também a sentir [...]. Nesse sentido, o longo aprendizado sobre emoções e afetos inicia-se nas primeiras horas de vida de uma criança e se prolonga por toda a sua existência" (Ibid., p. 23). Como os processos cognitivos e afetivos são carregados de conceitos, relações e práticas que os constituem como fenômenos histórico-culturais, a afetividade humana é construída culturalmente. As emoções são organizadas, concebidas e nomeadas de modo diferente em grupos culturais diversos. Nesse sentido, a linguagem tem papel fundamental como instrumento para constituição da afetividade, já que permite identificar, compreender, controlar e compartilhar emoções.

A individuação do sujeito se inicia nas experiências fornecidas pela cultura: "as funções psíquicas [...] estão intimamente vinculadas ao aprendizado, à apropriação (por meio da linguagem) do legado cultural [...]. O longo caminho do desenvolvimento humano segue, portanto, do social para o individual” (REGO, 2003, p. 27).

Ora, se a linguagem é constitutiva do ser humano, tanto no que diz respeito ao pensamento quanto à afetividade, é justo supor que, quanto mais abrangentes e complexas forem as formas lingüísticas e os gêneros textuais apresentados ao sujeito, mais modos de compreender a realidade, de estar no mundo e sobre ele atuar o sujeito terá à sua disposição. Estou dizendo, em outras palavras, que - ao contrário do que afirma Lajolo (2003), e correndo 
o risco de ser injustamente acusada de preconceito lingüístico - em sociedades letradas como a, o sujeito que diz "nós vai" talvez não possa expressar um pensamento ou um sentimento com a mesma sofisticação daquele que diz "nós vamos". Não por falta de domínio da chamada norma culta em si (para dispor dela se e quando necessário), mas apenas porque tal falta de domínio está freqüentemente vinculada à não escolarização, à não inserção em ambiente de letramento. Se a escola é agência privilegiada de mediação de saberes sistematizados, tão mais importante quanto mais desfavorecida for a camada social do sujeito, a não escolarização pode redundar numa menor sofisticação no uso de abstrações e $\operatorname{conceitos}^{18}$, e, portanto, na expressão de pensamentos e sentimentos ${ }^{19}$. Isso por sua vez, afetaria o modo de o sujeito estar no mundo e de nele intervir ${ }^{20}$.

E se não apenas o modo como pensamos é culturalmente mediado, mas também a forma como sentimos e se o significado e o sentido das palavras estão em constante mutação, a leitura literária - aquela que "questiona a significação, que busca o sentido, que persegue o valor mutante e mutável da palavra [...], que despreza o literal e valoriza o subjacente, o implícito" (SOARES, no prelo, p.4) - pode ser um excelente exercício de compreensão de linguagem. Como tal, é um exercício também de compreensão das formas diferentes de

\footnotetext{
${ }^{18} \mathrm{Na}$ abordagem vygotskiana, os conceitos são um sistema de relações e generalização presentes nas palavras e determinados por um processo histórico-cultural: "são construções culturais, internalizadas pelos indivíduos ao longo de seu processo de desenvolvimento" (OLIVEIRA, 1992, p. 28). O grupo cultural onde o indivíduo se desenvolve é que lhe fornece "o universo de significados que ordena o real em categorias (conceitos, por palavras da língua desse grupo" (Ibid., p. 28). Para Vygotsky, desenvolvimento e aprendizagem estão estritamente relacionados. Praticamente desde o nascimento, as crianças realizam uma série de aprendizados por meio da interação com o meio físico e social. Ou seja, antes de entrar na escola, a criança já construiu uma série de conhecimentos (conceitos, valores, idéias, objetos etc). Porém, ao ingressar nela, processa-se um outro tipo de conhecimento. Vygotsky distingue os conhecimentos cotidianos ou espontâneos - aqueles construídos na experiência pessoal, concreta e cotidiana, a partir da observação, manipulação e vivência direta da criança - dos conhecimentos científicos - aqueles não diretamente acessíveis à observação ou ação imediata da criança, ou seja, os conhecimentos sistematizados, adquiridos nas interações escolarizadas (REGO, 1995).Exemplifiquemos: um bebê que antes dizia "au au" para qualquer animal de quatro patas terá adquirido dois conceitos cotidianos novos quando passar a dizer "gato" e "cachorro". Mas provavelmente será apenas por intervenção escolar que ampliará os conceitos de gato e cachorro para algo mais genérico e abrangente. Assim, aprenderá o que ambos têm em comum entre si: ser mamíferos, vertebrados, simétricos, animais domésticos em oposição aos selvagens etc.
}

${ }^{19}$ Para exemplificar, desta vez, num contexto mais adulto, tomemos as palavras injustiça e mais-valia. Tanto pessoas não escolarizadas quanto escolarizadas dominam, ainda que com diferentes graus de sofisticação, o significado de injustiça. O mesmo não se pode dizer da palavra mais-valia, cuja aprendizagem demanda algum tipo de intervenção deliberada de alguém, a qual normalmente se dá na escola. Ora, embora haja intersecção na significação das duas palavras, o domínio da segunda delas supõe certos conhecimentos históricos e econômicos que favorecem um modo - digamos, por falta de termo melhor - mais qualificado de estar no mundo e de nele atuar.

${ }^{20}$ Dubet (2008) aponta a necessidade de modificações na escola para que ela se torne mais justa. Dentre os princípios de uma escola mais justa, o primeiro é a definição de uma norma de proteção que garanta uma cultura comum, que todo cidadão deve possuir, seja qual for a sorte que a competição e a igualdade das oportunidades lhe reservarão durante os estudos posteriores à escolaridade obrigatória. 
significar e de sentir a experiência humana, formas essas que têm algo de comum (no sentido de comuns ao Homo Sapiens ou ao nosso grupo cultural), mas que são também diversas entre grupos culturais diferentes, em momentos históricos distintos - e singulares - no plano de cada sujeito. Tal exercício, obviamente, favorece que se compreenda e sinta, que se apreenda melhor o ser humano, o nosso grupo cultural, o grupo cultural do outro, a si próprio e o outro. É nesse sentido que concordo com Antônio Cândido $\left(2004^{21}\right)$ quando defende que a literatura tem caráter humanizador. $\mathrm{O}$ autor entende por humanização "o processo que confirma no homem aqueles traços que reputamos essenciais", dentre os quais estão "o exercício da reflexão, a aquisição do saber, a boa disposição para o próximo, o afinamento das emoções, a capacidade de penetrar nos problemas da vida [...], a percepção da complexidade do mundo e dos seres" (Ibid., p. 180) ${ }^{22}$.

Novamente ao contrário do que se poderia supor apreendendo-se de modo fragmentado ou superficial os argumentos de Lajolo (2003) em favor da diversidade da leitura, a autora alerta contra o barateamento da noção de cultura e defende a necessidade de mediação da leitura:

[o professor] precisa transitar por todas essas formações culturais, deve ser capaz de ler os clássicos, os contemporâneos e os marginais [...]. Ao mesmo tempo, a familiaridade do professor com as diferentes culturas não pode baratear a noção de cultura [...] hoje, há uma tendência a se acreditar que a aprendizagem pode ser prazerosa, o que nem sempre é verdade. As noções de trabalho, de disciplina e de estudo estão sendo paulatinamente tiradas do contexto da escola e da aprendizagem. Assim, se dá ao aluno a idéia de que ele só terá de ler pela vida afora livros fáceis com letras grandes, com uma frase por página. Mas isso não basta, isso é apenas um ponto de partida para depois ele ler textos maiores e mais complexos [...] a idéia de que "ler é uma gostosa brincadeira" ou de que "ler é uma viagem pela imaginação" pode ser verdade às vezes, mas não o é sempre. Se tudo fosse tão bom e fácil, não seria preciso ir à escola, pois as pessoas aprenderiam a ler assim como se aprende a ver novela na TV. Mas há algo de específico na leitura que exige uma iniciação, e essa iniciação não é assim sempre tão fácil (LAJOLO, 2003, p. 50-51).

\footnotetext{
${ }^{21}$ Texto originalmente publicado em 1988.

${ }^{22}$ Abreu (2004) critica tal suposição do caráter humanizador da literatura "diante do fato de que há gente muito boa que nunca leu um livro e gente péssima que vive de livro na mão" (Idem, p. 89) e alude a figuras históricas que, ainda que apreciadoras de arte, cometeram atrocidades. Não cremos, no entanto, que seu argumento justifique a não adesão ao raciocínio de Cândido, pois a autora cita casos que nos parecem pouco representativos do que aconteceria com a maioria dos leitores. Afinal, como não se compadecer com o sofrimento do protagonista de Os Miseráveis (Hugo, V.) e, a partir de tal empatia, reconsiderar alguns posicionamentos políticos, à época de sua publicação? Contemporaneamente, parece-me também muitíssimo possível que a leitura da trajetória de Reizinho, o protagonista de Inferno (Melo, P.), proporcione uma compreensão diversa da hegemônica, menos preconceituosa, mais humana, das condições de vida (essas, sim, desumanas) de crianças e adolescentes das camadas mais empobrecidas da população.
} 
Ora, mediação e mediador, termos que percorrerão toda a pesquisa, à custa de tanto serem utilizados no dia-a-dia nos contextos mais diversos, acabam por ter significação tão ampla que ficam esvaziados. No dicionário Houaiss, mediação apresenta dez significados e mediador, por sua vez, não menos que seis. Ambas as palavras demandam, portanto, um esforço de circunscrição de significado.

Em termos genéricos, mediação é o "processo de intervenção de um elemento intermediário numa relação; a relação deixa, então, de ser direta e passa a ser mediada por esse elemento" (OLIVEIRA, 1997, p. 26). No paradigma vygotskiano, o termo mediação tem dois sentidos: "o outro" é mediador entre o sujeito e a cultura. E a cultura, por sua vez, é mediadora entre o sujeito e os objetos da realidade.

Conforme comenta Rego (1995), Vygotsky atribui grande importância ao papel que a interação social exerce no desenvolvimento do ser humano. Para ele, aquilo que é inato, a estrutura biológica, não basta para produzir o indivíduo humano na ausência do ambiente social. Os fatores biológicos preponderam sobre os sociais apenas no início da vida da criança. Gradativamente, as interações com o grupo social e com os objetos da cultura passam a dirigir o comportamento e o desenvolvimento de seu pensamento. Desde o nascimento, os adultos medeiam a relação do bebê humano com o mundo, procurando "incorporar as crianças à sua cultura, atribuindo significados às condutas e objetos culturais que se formaram ao longo da história” (Idem, p. 59). É com o auxílio do adulto que as crianças aprendem ativa e dialeticamente as habilidades que foram construídas pela história social (sentar-se, andar, falar, etc). É também por meio das intervenções constantes dos adultos e de crianças mais velhas que os processos psicológicos mais complexos começam a se desenvolver:

Assim, o desenvolvimento do psiquismo humano é sempre mediado pelo outro (outras pessoas do grupo cultural), que indica, delimita e atribui significados à realidade. Por intermédio dessas mediações, os membros imaturos da espécie humana vão pouco a pouco se apropriando dos modos de funcionamento psicológico, do comportamento e da cultura, enfim do patrimônio da história da humanidade e de seu grupo cultural. Quando internalizados, estes processos começam a ocorrer sem a intermediação de outras pessoas (Ibid., p. 61).

As origens das funções psicológicas superiores, típicas do ser humano (como o controle consciente do comportamento, a ação intencional e a liberdade em relação ao momento e espaço presentes) devem ser procuradas nas relações sociais entre o indivíduo e os outros. Os elementos mediadores (instrumentos, signos e todos os elementos do ambiente carregados de significado) são dados pelas relações interpessoais, ou seja, são eles próprios mediados. Ao longo do desenvolvimento tanto da espécie quanto do indivíduo, as relações 
mediadas (por instrumentos, signos e pelo outro) passam a predominar sobre as diretas. A invenção e o uso de signos como auxiliares para solucionar um problema (lembrar, comparar, relatar, escolher, etc) é comparada por Vygotsky à invenção e uso de instrumentos: os signos seriam, então, "instrumentos psicológicos". Em sua analogia com os instrumentos de trabalho, os signos aparecem como marcas externas, que suportam a atuação do homem sobre o mundo. Ocorrem, durante o desenvolvimento da espécie humana e do indivíduo, duas mudanças qualitativas no uso de signos: a internalização e o desenvolvimento de sistemas simbólicos (OLIVEIRA, 1997).

No processo de internalização, a utilização de marcas externas se transforma em processos internos de mediação: “o indivíduo deixa de necessitar de marcas externas e passa a usar signos internos, isto é, representações mentais que substituem os objetos do mundo real" (Idem, p. 35). Tal capacidade de lidar com representações do real permite que o ser humano se liberte do espaço e tempo presentes, faça relações mentais na ausência das próprias coisas, imagine, faça planos e tenha intenções. $\mathrm{Na}$ relação do homem com o mundo, "as representações mentais da realidade exterior são, na verdade, os principais mediadores a serem considerados" (Ibid., p. 35). Ao longo da história da espécie humana, tais representações da realidade têm se articulado em sistemas simbólicos. Tais sistemas - dentre os quais a linguagem é o sistema simbólico básico de todos os grupos humanos - são socialmente dados: "é o grupo cultural onde o indivíduo se desenvolve que lhe fornece as formas de perceber e organizar o real, as quais vão constituir os instrumentos psicológicos que fazem a mediação entre o indivíduo e o mundo" (Ibid., p. 36). Na qualidade de mediadores entre o indivíduo e o mundo real, esses sistemas simbólicos consistem numa espécie de filtro através do qual o homem será capaz de perceber o mundo e sobre ele operar.

Por essa razão, é tão imperioso, no escopo de minha pesquisa, investigar quais foram as oportunidades de mediação de leitura que os sujeitos tiveram ao longo de sua vida (e os âmbitos em que elas aconteceram) para se constituírem leitores em condições tão adversas.

\section{$1.4 \mathrm{O}$ abismo entre a literatura e a escola e entre a escola e as camadas populares}

Quando se mergulha no universo escolar, as constatações sobre o sucesso na formação de leitores de literatura não são muito alentadoras. Regina Zilberman, ao discutir a difusão da literatura pela escola, e em particular pelo livro didático - o qual "engloba a tradição literária e atua como seu portador mais credenciado" (2003, p. 247) -, afirma que a formação literária 
durante todo o século XX não levou o aluno ao mundo dos livros. Ela discute várias facetas dessa dissociação entre literatura e leitores, em especial daqueles pertencentes às camadas populares.

De acordo com Zilberman, a primeira e mais duradoura grande teoria da leitura foi a que dispôs do ensino e da pedagogia como um de seus principais difusores. Iniciou-se entre os gregos, os quais, assim como ainda se faz hoje, partiam da alfabetização, para alcançar o conhecimento do texto literário, iniciando do mais próximo para atingir o distante. Para se alcançar esse objetivo, duas medidas foram necessárias: organizar a instituição responsável pela profissionalização da atividade pedagógica - a escola; e separar a religião e a poesia. No entanto, embora transferida do estatuto do sagrado para o profano, a literatura continuou a ser venerada como algo santificado, representativa de um patrimônio precioso. A poesia, concebida como uma entidade elevada, destinava-se somente aos grupos dominantes, os únicos na história ocidental a terem, por muitos séculos, acesso à educação.

No século $\mathrm{XX}$, os Estudos Literários mantiveram a elitização da literatura,

deixando os consumidores de fora, colaborando para o aprofundamento das diferenças que geram dois modos de exclusão: de um lado, a Teoria da Literatura alça seu objeto a um patamar de excelência que o distancia dos leitores; de outro, esses aceitam que a literatura não faça parte de sua vida ou não a entendem como tal (ZILBERMAN, 2003, p. 263).

As transformações históricas provocadas pelo capitalismo, do século XV até o século XVIII, demandaram alterações no ensino. A palavra de ordem passou a ser escolarização em massa. Não se tratava mais de aplicar o processo importado dos gregos, mas de introduzir as massas de usuários ao mundo das letras de forma rápida e eficiente, os quais, de origem humilde, supostamente não sentiam falta da escrita e da leitura de textos. Como resultado, "a teoria da leitura não pôde mais se confinar à literatura" (Ibid., p. 264) e, desde o século XIX e especialmente no século XX, proliferaram as teorias da alfabetização. O letramento tornou-se um segmento autônomo das teorias da leitura. De acordo com Zilberman,

a peculiaridade das teses relativas ao letramento, mesmo quando se fala das idéias progressistas de Paulo Freire, no âmbito da pedagogia, ou de Emília Ferreiro e Ana Teberosky, no campo da lingüística, é que se apresentam como um fim em si mesmas, não mais na condição de passagem para a literatura. Assim, se antes - conforme o modelo originário da Grécia que institucionalizava o canônico e que ainda vigora nos Estudos Literários - a literatura ficava no fim ou de fora, agora ela não está em parte alguma. A dissociação faz com que a literatura permaneça inatingível às camadas populares, que tiveram acesso à educação, reproduzindo-se a diferença por 
outro caminho, respondendo os letrados não mais por aqueles que sabem ler, e sim pelos que lidam de modo familiar com as Letras, os especialistas (Ibid., p. 265).

Para Zilberman, as discriminações que estavam no seio da sociedade migraram para as teorias da leitura. Até um certo ponto da história ocidental,

[o leitor] era formado para a literatura; hoje, ele é alfabetizado para entender textos [...] como querem os PCNs, em que se educa para ler, não para a literatura. Assim, nem sempre a literatura se apresenta no horizonte do estudante, porque, de um lado, continua ainda sacralizada pelas instituições que a difundem, de outro, dilui-se no conceito vago de texto ou discurso (ZILBERMAN, 2003 p. 265).

Ainda segundo Zilberman, o livro é "o grande excluído do ensino", porque se se apresenta ao leitor, é sob a forma de livro didático, de súmula de trechos de textos, de fragmentos fragilmente costurados. O conceito de literatura proposto no livro didático isola uma parte - o texto - do todo, o livro, produto material que congrega autor e obra, sociedade e mundo representado, cultura e economia.

A autora defende que se admita o livro como face material da literatura, como mercadoria, produto de uma série de profissionais de uma indústria que visa ao lucro. Negarse a admitir tal caráter econômico significa idealizar o livro, elitizando-o por outro caminho. "Compreendê-lo na sua materialidade aproxima-o da situação concreta de seus usuários" (Ibid., p. 266). É justamente desse ponto de vista da materialidade dos textos, com ênfase no papel social dos agentes (autor, editor e instâncias sociais) envolvidos na elaboração, fabricação e disponibilização do texto enquanto material escrito que Pietri (2007) analisa os materiais didáticos e as práticas de leitura na escola, ou, em termos vygotskianos, a qualidade da mediação oportunizada tanto pelo livro didático em si quanto pelo professor. $\mathrm{O}$ autor aponta para as dificuldades que a superficialização, que redunda das estratégias de facilitação e de fragmentação do texto, pode oferecer ao trabalho com a leitura e a formação de leitores. As estratégias de facilitação realizam-se com a "supressão de passagens que exigem a ativação de um conhecimento prévio específico", com a seleção de textos que não ofereçam problemas para o leitor pouco proficiente. As estratégias de fragmentação expressam o rompimento "da ordem em que nos encontramos como produtores/leitores em sociedade", entre outros fatores pela desconstrução da noção de autoria (Ibid., p.38-39).

Segundo Pietri, as decisões sobre o texto a ser lido na escola, no [seu] caminho que vai da obra em que foi publicado originalmente até o livro didático, são tomadas segundo um 
conjunto de critérios baseados em imagens empobrecidas do professor e do aluno e das competências de leitura de ambos. Nessa trajetória, o texto freqüentemente "passa por um processo de descontextualização, tanto em relação aos fatores históricos e sociais que envolvem sua produção e sua recepção, quanto em relação às características da obra em que está inserido" (Ibid., p. 83). O fato de considerar a leitura de um texto independentemente das condições de sua produção pode estar vinculado a uma concepção de leitura que não percebe diferenças nas práticas que envolvem o ato de ler, e nos objetos que sustentam essas práticas. Como resultado, "são apagadas as diferentes valorações sociais, políticas e históricas que possuem os textos e as práticas de leitura que os envolvem”. Dá-se, assim, "uma ruptura em relação aos modos como os textos e as práticas de leitura são produzidos fora do contexto escolar" (PIETRI, 2007, p. 83). Em suma, a mediação dos textos não favorece a formação de um leitor que saiba ler e produzir textos escritos segundo os modos como a produção e a leitura de textos escritos se organizam em comunidades com altos níveis de letramento.

Soares (1999, p. 47), discutindo mais especificamente a escolarização da literatura infantil, ou seja, a apropriação dessa literatura pela escola, defende que tal escolarização é inevitável, já que "é da essência da escola a instituição de saberes escolares, que se constituem pela didatização ou pedagogização de conhecimentos e práticas culturais". No entanto, distingue o que seria escolarização adequada e inadequada da literatura. A escolarização adequada conduziria o aluno "às práticas de leitura literária que ocorrem no contexto social e às atitudes e valores próprios do ideal de leitor que se quer formar" (Ibid., p. 47). Já a inadequada escolarização da literatura a distorce e falsifica, e acarreta o afastamento do aluno das práticas de leitura literária, desenvolvendo nele resistência ou aversão ao livro e ao ato de ler.

Dentre as instâncias de escolarização da literatura, a mais freqüente e inadequada para não dizer desastrosa - é a leitura e o estudo de fragmentos de textos da literatura infantil:

inadequada porque há uma seleção limitada de tipos e gêneros, porque há uma escolha pouco criteriosa de autores e obras, e, sobretudo, porque os textos são quase sempre pseudotextos, isto é, fragmentos sem textualidade, sem coerência; e ainda porque as atividades que se desenvolvem sobre os textos não se voltam nem para textualidade nem para a literariedade do texto. Não será excessivo afirmar que a obra literária é desvirtuada, quando transposta para o manual didático, que o texto literário é transformado, na escola, em texto informativo, em texto formativo, em pretexto para exercícios de metalinguagem (Ibid., p. 47).

Dessa forma, perde-se a oportunidade de desenvolver na criança a apreciação do caráter lúdico, prazeroso, estético inerente ao texto literário. 
Interessante observar que, embora o conjunto de autores citados anteriormente não utilizem essa terminologia quando falam no trabalho feito com a literatura pela escola, na escolha e apresentação do material e nas práticas docentes, estão tratando daquilo que podemos chamar, na perspectiva vygotskiana, de mediação.

Ora, se, conforme aponta a pesquisa Retratos da Leitura no Brasil, o desenvolvimento de práticas de leitura está muito vinculado ao fato de estar na escola e de nela ter acesso a livros didáticos, se a apresentação de textos nos materiais didáticos de língua portuguesa não favorece a formação de um leitor segundo os modos de ler de comunidades com alto grau de letramento (PIETRI, 2007) e se a escolarização da literatura desde os anos iniciais do ensino fundamental freqüentemente é realizada de modo inadequado e até negativo, o qual pode acarretar aversão pela leitura (SOARES, 1999), está reiterada a improbabilidade de formação de leitores literários nas camadas populares (ZILBERMAN, 2003). Estariam menos à mercê dessa freqüente e inadequada didatização ou escolarização da literatura apenas os filhos de famílias mais favorecidas, as quais, além de lhes ofereceram material impresso, também desenvolvessem a leitura de literatura infantil e juvenil no ambiente doméstico.

Bourdieu (1998), criticando o papel de preservação dos privilégios das classes dominantes exercido pela escola, discute as relações entre essa instituição e a prática cultural e desconstrói a idéia de "desigualdade natural das necessidades culturais". Para o autor, "o acesso às obras culturais permanece como privilégio das classes cultivadas” (Ibid., p. 59). Exemplo disso seriam os dados sobre a freqüência a museus, a qual estaria estreitamente relacionada ao nível de instrução da família. Apenas a escola pode criar a aspiração à cultura, ou seja, as necessidades culturais são produto da educação. Assim, "a privação em matéria de cultura não é necessariamente percebida como tal, sendo o aumento da privação acompanhado, ao contrário, de um enfraquecimento da consciência da privação" (Ibid., p. 5960). Ora, se no domínio das necessidades culturais, "o papel das incitações difusas propiciadas pelo meio familiar é particularmente determinante” (Ibid., p. 61), e se a escola não exerce a contento seu papel de fomentar o ensino artístico ou de incitar a prática cultural (de visita a museus, neste caso), através de uma ação metódica, ela deixa de dar a todos a incitação que alguns recebem de seu meio família.

Estabelecendo-se um paralelo entre a freqüência a museus e o acesso à literatura, que apenas a escola poderia prover no caso das camadas populares (BOURDIEU, 1998) e que a escola não provê (ZILBERMAN, 2003), a formação de leitores literários torna-se ainda mais improvável nas camadas populares. 
Ora, se "o nível de letramento de grupos sociais relaciona-se fundamentalmente com as suas condições sociais, culturais e econômicas" (SOARES, 1998, p. 58), se há no Brasil uma "perversa relação entre a distribuição de renda no País e as condições de acesso à leitura" (SOARES, 2004, p. 24), se a democratização da leitura "depende de mudanças estruturais que ultrapassam o educacional e o cultural (Idem, p. 25), como se constituem alguns leitores em comunidades de nível socioeconômico desfavorecido? E se a literatura esteve, ao longo da história ocidental, e permanece hoje ainda "inatingível às camadas populares" (ZILBERMAN, 2003, p. 265), como alguns sujeitos, para além de exercitarem a leitura funcional e de entretenimento chegam a constituir-se leitores que incluem em seu leque de leituras a literária (SOARES, no prelo)? E se "o livro é o grande excluído do ensino" (ZILBERMAN, 2003), como alguns sujeitos se tornam leitores de literatura no portador livro?

Um bom exemplo do quão intrigante é esse tema é o caso do escritor Ferréz, morador do bairro Capão Redondo, na periferia de São Paulo, que se constituiu leitor a despeito de suas dificuldades de acesso à leitura. Ferréz, nome literário de Reginaldo Ferreira da Silva, nascido em 1975, é um híbrido de Virgulino Ferreira (Ferréz), nome do cangaceiro Lampião, e de Zumbi dos Palmares (Z). Filho de um motorista e de uma empregada doméstica, Ferréz relata que, mesmo quando ficou desempregado ${ }^{23}$, vendeu camisa, vassoura, reformou bares e lixou paredes de apartamento, mas jamais deixou de ler as obras de seus autores preferidos, Carlos Drummond de Andrade, Manuel Bandeira e Dostoievski, mesmo que tivesse que pegar duas conduções até a biblioteca mais próxima. Segundo o escritor, a literatura funcionou, para ele, como uma saída de emergência, uma espécie de salvação ${ }^{24}$.

Em 1997, Ferréz publicou seu primeiro livro, Fortaleza da Desilusão. Em 2000, lançou Capão Pecado (Objetiva, 2005). É também autor de Manual Prático do Ódio (Objetiva, 2003), Amanhecer Esmeralda (Objetiva, 2005) e Ninguém é Inocente em São Paulo (Objetiva, 2006). Escreve uma coluna na revista Caros Amigos. É criador do projeto e editor-chefe da revista Literatura Marginal, a qual recebeu o Prêmio da Associação Paulista de Críticos de Arte (APCA) de Melhor Projeto de Literatura de $2001^{25}$.

\footnotetext{
${ }^{23}$ Antes de se dedicar exclusivamente à escrita, Ferréz trabalhou como balconista de bar e padaria (dos 12 aos 16 anos), e auxiliar-geral e arquivista.

${ }^{24}$ Editora Objetiva. Recuperado em 15 dez. 2006: http://www.objetiva.com.br/objetiva/cs/?q=node/81

${ }^{25}$ Itaú Cultural. Recuperado em 15 dez. 2006: http://www.itaucultural.org.br/aplicexternas/enciclopedia/ poesia/index.cfm); Editora Objetiva. Recuperado em 15 dez. 2006: http://www.objetiva.com.br/objetiva $/ \mathrm{cs} / \mathrm{q}=$ node/81)
} 
O exemplo de Ferréz, por um lado, aponta para a possibilidade de uma constituição leitora paradoxal e, por outro, leva a pensar que tipo de escola está sendo freqüentada por sujeitos que, assim como ele, têm famílias de origem socioeconômica baixa. Afinal, em toda a discussão que fiz até o momento sobre a escolarização da literatura, pensei na escola de modo mais genérico, como se a qualidade da oferta educativa a todas as camadas sociais e em todas as regiões do Brasil e da cidade de São Paulo fosse a mesma. Desnecessário dizer que não o é.

Sposito (2008), para descrever a onda de expansão da escolaridade que tem início nos anos 1990, adota o termo "expansão degradada", cunhado por Peregrino (2006), que investigou os últimos 30 anos de funcionamento de uma escola pública na cidade do Rio de Janeiro. Para os novos usuários da escola - os filhos das camadas populares -, trata-se de uma expansão importante, do acesso a um direito que antes lhes era negado, mas que se dá em condições degradadas. Embora $60 \%$ da população entre 15 e 24 anos esteja na escola, esta se mostra muito distante dos jovens, seja porque boa parte desses jovens não tem condições de acesso ou de permanência nela, seja porque novas desigualdades surgiram:

parcela significativa ainda não tem possibilidades efetivas de acesso ou de permanência em função das condições precárias de vida. Por outro lado, a própria expansão produz novas desigualdades internas aos sistemas de ensino: ausência de recursos materiais e humanos para assegurar uma escola minimamente capaz de ser significativa para amplos segmentos juvenis e escolas com qualidade diversa para públicos socialmente diversos (patamares de funcionamento diferentes entre a rede pública e privada ou mesmo no interior da rede pública) (SPOSITO, 2008, p. 85).

Além disso, o tempo e energia disponíveis para a escolarização competem, no caso dos jovens das camadas populares, com a urgência de se inserir no mercado de trabalho. A partir de dados da pesquisa Perfil da juventude brasileira, de caráter nacional, Sposito avalia que "os jovens, apesar da expansão do sistema escolar, estão muito mais próximos do mundo do trabalho do que das instituições educativas"26 (Ibid., p.86).

O caráter precário da oferta educativa se agrava no Ensino Médio - justamente o período em que o currículo escolar privilegia o trabalho com os clássicos da literatura -, Ensino Médio esse descrito por Sposito como um “caldeirão de tensões", elucidativo das "novas contradições e desigualdades que decorrem da ampliação das oportunidades de acesso

\footnotetext{
${ }^{26}$ Ainda de acordo com a pesquisa, $60 \%$ dos entrevistados trabalhavam, mas $75 \%$ já estavam na esfera do trabalho, isto é: estavam ocupados, em busca de emprego ou desempregados (GUIMARÃES, 2005; SPOSITO, 2005).
} 
à escola ${ }^{27 "}$ (Ibid., p. 86). Uma das tensões emergentes reside no tema da identidade. Qual é a identidade desse nível da escolaridade que hoje integra a educação básica? Tradicionalmente, o antigo ensino secundário foi projetado para a formação das elites e, portanto, teve como meta a preparação para o acesso à universidade. A questão é que, para muitos jovens das famílias populares, o Ensino Médio é o nível de escolarização terminal.

Para a maioria desses jovens, concluir o Ensino Médio representa uma vitória. No entanto, trata-se de uma vitória que produz um vácuo, pois eles não têm perspectivas imediatas de continuar a estudar. A inserção no mercado de trabalho também não está garantida, já que os índices de desemprego juvenil são mais altos do que os da população adulta. Verifica-se assim uma forte contradição nesse nível de ensino:

enfim, há um paradoxo já no início da expansão recente do acesso à escola sob o ponto de vista dos jovens: de um lado o forte reconhecimento de que a escolaridade é fundamental e, ao mesmo tempo, a ausência de sentido imediato para essa escola. Ocorre uma espécie de dialética entre o sentido possível do projeto escolar que se volta para o futuro e a ausência de sentido do tempo escolar presente (SPOSITO, 2008, p. 87).

Ora, se a principal influência leitora parece vir da família (Retratos da Leitura no Brasil, 2007), se a imensa maioria das famílias brasileiras possuem baixo grau de escolarização e não estão imersas em ambientes que propiciem nem o letramento nem o letramento literário (SOARES, 1998, 2004), e se a escola enfrenta dificuldades para cumprir a contento seu papel de formar leitores (CUNHA, 2008), e ainda mais leitores de literatura (ZILBERMAN, 2003; PIETRI, 2007; SOARES, 1999), e se há um abismo entre a escola e os estudantes das camadas populares, abismo esse que se acentua no Ensino Médio (SPOSITO, 2008), período em que se privilegia o ensino de literatura, pergunto-me como alguns poucos sujeitos, a exemplo de Ferréz, constituem-se paradoxalmente não apenas leitores, mas também leitores de literatura?

\footnotetext{
${ }^{27}$ Segundo Sposito, os dados do próprio governo indicam tal precariedade. Nas provas do Exame Nacional do Ensino Médio (ENEM) de 2006, em uma escala de 0 a 100, a média nacional dos alunos foi somente 36,9 pontos. O mais grave é que ela foi menor do que aquela aferida em 2005, de 39 pontos. Os estudantes de escolas públicas tiveram média de 34,94 contra média 50,57 de jovens de escolas particulares. Também bastante significativa é a evasão de alunos do ensino médio: $15 \mathrm{em}$ cada 100 jovens matriculados abandonaram a escola em 2004. Especificamente quanto às habilidades básicas de leitura e escrita, os dados também são desoladores. Os resultados do Sistema de Avaliação do Ensino Básico (SAEB) indicam uma diminuição no nível de aproveitamento dos estudantes do último ano do ensino médio das escolas públicas. Entre 1995 e 2005, a média em Língua Portuguesa diminuiu em 46 pontos; em Matemática, a queda foi de 20,6 pontos (CORTI et al., 2007, p 5, apud SPOSITO, 2008).
} 
Capítulo 2

Em busca da compreensão de constituições leitoras paradoxais

Eu quase nada não sei. Mas desconfio de muita coisa. O senhor concedendo, eu digo: para pensar longe, sou cão mestre - o senhor solte em minha frente uma idéia ligeira, e eu rastreio essa por fundo de todos os matos, amém! 


\subsection{Pesquisas acadêmicas recentes sobre a formação de leitores}

De acordo com Ferreira (2003), que elaborou um catálogo de dissertações de mestrado e teses de doutorado no campo da leitura, entre 1965 e 1979, houve apenas 22 trabalhos sobre leitura. A partir de 1980, o número de estudos cresceu significativamente. De 1980 a 1995 , foram realizadas 189 pesquisas. E entre 1995 e 2000 o número de investigações elevou-se para 219, o que revela o crescente interesse pela leitura como objeto de estudo ${ }^{28}$. Ferreira classifica os trabalhos realizados a partir de 1980 em oito categorias de análise. A primeira delas é compreensão e desempenho em leitura, que conta com 150 estudos. Nessa categoria, vem aumentando o número de estudos em que a compreensão é encarada como um processo interativo de construção de sentidos ou como uma prática discursiva nas relações intertextuais, contextuais, dialógicas e interdisciplinares.

As pesquisas da segunda categoria - análise do ensino de leitura e proposta didática discutem as condições de produção de leitura na escola, situações de leitura e projetos para a biblioteca. Dentre os 113 estudos dessa categoria, a maioria aborda o distanciamento do leitor em relação ao texto na escola e apenas alguns (como é o caso de PIOVESAN, 1999 e UZEDA, 1992) tratam de propostas escolares bem-sucedidas.

A terceira categoria intitula-se leitor: suas preferências, hábitos, representações $e$ histórias e conta com apenas 50 trabalhos. Nesta categoria, há pesquisas sobre a influência da escola e da família na formação do leitor. Nos estudos de Araújo (1999) e Marques (1999), por exemplo, a família é considerada o principal contexto de experiências prazerosas com a leitura. Já no trabalho de Perrotti (1999), a escola é indicada como o espaço mais favorável à formação do leitor. Nessa categoria de investigação, há estudos cujo enfoque é o de que as interações sociais têm papel fundamental na formação do leitor. Têm tal enfoque os trabalhos de Perrotti (1989), Facchini (1996), Simões (1999), Reyes (2000) e Grotta (2000).

Uma quarta categoria elencada por Ferreira é professor e bibliotecário como leitor, que conta com 41 trabalhos sobre a qualificação e a necessidade de melhor formação desses profissionais. As outras categorias são: o texto de leitura em circulação na escola (25 trabalhos); memórias da leitura, do leitor e do livro (18 estudos); concepção de leitura (5 pesquisas); o estado do conhecimento sobre leitura (2 trabalhos).

\footnotetext{
${ }^{28}$ Mesmo considerando-se o aumento no número de pessoas que fazem pós-graduação, o que relativiza esses resultados, os números absolutos demonstram um crescente interesse pela questão da formação de leitores.
} 
Essa breve exposição do quadro de pesquisas sobre leitura no Brasil evidencia que ainda é reduzido o número de pesquisas sobre o processo de constituição de leitores. Além disso, vários trabalhos indicam que a escola ainda não consegue estimular uma boa aprendizagem de leitura, sendo a família indicada como o contexto em que as experiências mais favoráveis e significativas se dão.

Interessante observar o trabalho de Grotta (2000), elencado por Ferreira. A autora investiga a formação de leitores através do relato autobiográfico oral de quatro adultos, professores universitários, à luz dos pressupostos vygotskianos. Entre tais pressupostos está o de que o homem se constitui sujeito através da mediação do outro, do signo, das interações sociais e de que a linguagem ocupa posição privilegiada na interação humana e na constituição do sujeito. Grotta destaca a importância da mediação de outros leitores na constituição de cada sujeito. Amparada ainda em Benveniste e Bakhtin, a autora fala de uma concepção dialética da linguagem. Ela conclui sua pesquisa ressaltando o papel da mediação do outro (seja ele uma pessoa concreta ou um autor) e da leitura na constituição do sujeito e salienta aspectos que influenciariam a formação do leitor, tais como os elogios e incentivos vivenciados na escola, a admiração nutrida pelo sujeito por alguém que seja modelo de leitor, a possibilidade de conquistar apreciação do outro graças aos conhecimentos adquiridos pela leitura, o acesso a livros e a qualidade desses.

Partindo do princípio de que toda interação com um objeto cultural acontece de forma mediada, Grotta conclui que a qualidade das mediações é um elemento fundamental na formação de sujeitos leitores:

foram as relações sociais vivenciadas pelos sujeitos em torno da cultura escrita e a qualidade afetiva presente nessas relações que foram imprimindo um sentido afetivo à atividade de ler, aos objetos de leitura (livros, jornais, revistas) e a lugares de leitura (biblioteca, quarto, praça pública etc), transformando a atividade de ler em algo significativo para os sujeitos (2000, p. 161).

Considerando que "a formação de um sujeito enquanto leitor também é marcada pela relação de complementaridade entre os aspectos afetivos e cognitivos que permeiam o desenvolvimento do ser humano como um todo", Grotta verifica que, de fato, na história dos sujeitos entrevistados, afetividade e cognição "configu[ra]ram-se como elementos constantes e motivadores de suas práticas de leitura" (Ibid., p. 163).

A pesquisadora ressalta que, entre seus sujeitos, as interações com a leitura de textos mediados pelo ‘outro' e perpassadas de forte vínculo afetivo não foram algo característico 
apenas da infância, não se derem somente no âmbito familiar e nem estiveram restritas a poucos mediadores. Na história de dois dos quatro sujeitos, desde a infância "houve sempre uma pessoa próxima dos mesmos (com forte vínculo afetivo) que, sendo leitora e atribuindo grande valor à cultura letrada, acompanhou e incentivou a relação destes com a leitura durante todo o percurso de formação dos mesmos". No caso de um deles, foi a mãe. No de outro, foi o tio. Já na história dos dois outros sujeitos, não houve interações com a leitura com uma pessoa de maneira constante desde a infância, no âmbito da família, mas com várias pessoas durante períodos mais curtos em espaços diferentes, em especial na escola (GROTTA, 2000, p. 163166).

No espaço escolar, "durante a aprendizagem da leitura e da escrita, as relações afetivas que permeiam as interações dos sujeitos com a leitura começam a ser alimentadas através de elogios e incentivos às suas atividades intelectuais, principalmente através dos professores". No percurso escolar dos quatro sujeitos, principalmente a partir do $2^{\circ}$. segmento do ensino fundamental,

os elogios do professor às suas redações, a valorização das idéias que expressavam em debates, o acompanhamento do mesmo às leituras que realizavam em comum, a indicação de leituras a partir do centro de interesse do aluno ou do conteúdo das aulas, o empréstimo de livros, os elogios aos seus progressos cognitivos, ou ainda, o recebimento de premiações são alguns exemplos de formas cognitivas de expressar afeto que estimularam os sujeitos desta pesquisa a ler e a ampliar seus referenciais de leitura (Ibid., p. 166).

Os sujeitos, que nutriam grande admiração por seus professores quanto à forma de ser, de pensar e de ler, desejavam se identificar com eles, o que buscavam por meio da leitura dos mesmos títulos lidos ou citados por seus professores, da imitação de suas formas de ler e do valor que atribuíam à leitura. Em outras palavras, os referidos professores configuravam-se como modelos de leitores. Os docentes angariavam a admiração dos sujeitos por seus conhecimentos e por sua relação muito positiva com o saber e a leitura:

os professores conquistavam a admiração dos sujeitos/alunos através do grande conhecimento que demonstravam ter sobre o conteúdo das disciplinas, pela satisfação que possuíam em ensinar e pelo prazer que expressavam em ler e conhecer. A forma como os professores desses sujeitos apresentavam a leitura em sala de aula, liam e demonstravam a relação entre seu saber e suas leituras revelava não só o prazer que tinham em ler, mas também o quanto a leitura era constituinte da subjetividade de cada um deles (Ibid., p. 175). 
Sampaio (2005), abordando o tema do letramento de uma perspectiva da Psicologia Cultural (preconizada por Bruner), também ressalta o papel do "outro" social na formação da criança leitora. Sua investigação também se baseou em narrativas orais autobiográficas. Ela estudou a formação leitora de oito crianças com cerca de 10 anos. Quatro dessas crianças são alunas de uma escola privada de ponta e quatro outras estudam numa escola pública ligada à Faculdade de Educação da Universidade de São Paulo.

A pesquisa indica que os "outros sociais" que possibilitaram o letramento dessas crianças estavam materializados nos "sujeitos-leitores" significativos que conviveram com elas, nos "objetos-livros" a que tiveram acesso e nos "lugares e experiências de leitura". Sampaio esboça o seguinte perfil do bom leitor: "prazer pela leitura, assiduidade e formação de repertório, criticidade e formação de preferências e autonomia para a prática de leitura”. Para a autora, tais características parecem estar muito vinculadas às "condições de formação desse bom leitor", ou seja, de "acesso e prática de uma leitura 'prazerosa e significativa' na família e na escola, de convívio com leitores que cumprem o papel de modelos e interlocutores e de valorização da leitura e de si enquanto leitor” (SAMPAIO, 2005, p. 70).

Para a formação de leitores, Sampaio confirma, a partir dos dados de sua pesquisa, o que estudos anteriores por ela revistos também haviam apontado, ou seja:

a importância da família, da escola, do acesso aos livros, das interações sociais e das vivências positivas relacionadas à leitura e, de um modo mais específico, de experiências relacionadas a atividades significativas de leitura em grupo [...], do papel orientador do adulto, de um ensino que considere o significado e o prazer de ler, de uma boa formação literária do professor, de experiências positivas em bibliotecas e da não obrigatoriedade da leitura (Ibid., p. 70).

A pesquisadora reitera que experiências escolares bem-sucedidas relacionadas à leitura, como aquelas presentes nas escolas freqüentadas por seus pesquisados, podem ser determinantes na formação leitora dos sujeitos. Porém, chamou-me a atenção o fato de que, entre as oito crianças, seis apontaram a família como a principal instância formadora. Apenas dois sujeitos apontaram a escola. Curiosamente, esses dois sujeitos pertencem a famílias abastadas. Isso me leva a duas inferências: a) mesmo quando os projetos de leitura desenvolvidos na escola são muito bons, a família ainda tem papel preponderante para a formação leitora; b) o fato de se pertencer a famílias de maior capital econômico, nas quais o acesso a material impresso, em tese, seria mais farto, não garante por si só a formação do leitor. 
A pesquisa de Sampaio aponta para uma relativização da relevância do pertencimento às camadas populares ou às de maior poder aquisitivo para a formação de leitores. De fato, nas famílias de todos os oito sujeitos, sem distinção de capital econômico ou cultural, a pesquisadora encontrou "práticas favoráveis de relação com a cultura escrita, seja através da prática de pais efetivamente leitores (na maioria dos casos) ou daqueles que, ao menos, expressavam uma valorização da leitura para seus filhos" (SAMPAIO, 2005, p. 58).

No entanto, cabe ponderar se ambos os resultados da análise - o sucesso das experiências de leitura na escola e a relativização da importância do nível socioeconômico da família a que se pertence - não se devem à escolha da escola pública pesquisada, a qual, além de estar localizada numa região de classe média, é conhecida pela excelência de seu trabalho e por atender um público diferenciado, que inclui filhos de funcionários, alunos e professores da Universidade de São Paulo. Não por acaso, apenas os pais de uma das crianças não tinham atingido o Ensino Superior, e 7 dos 8 sujeitos relataram ter farto acesso a leitura através da compra e da presença de livros em casa.

Tendo em vista as duas investigações acima, perguntei se encontraria resultados semelhantes ao pesquisar a constituição de jovens leitores pertencentes a camadas mais desfavorecidas da população e alunos de escolas públicas de bairros muito periféricos, filhos de pais pouco letrados ou mesmo não alfabetizados. O que seria mais significativo para sujeitos dos meios populares, com idades entre 18 e 30 anos, na sua constituição como leitores de literatura?

Em trabalho mais recente, Oliveira (2008), amparada nas análises sociológicas de Bourdieu e Lahire, realizou uma pesquisa quantitativa com 87 docentes, com o objetivo de traçar um perfil médio do professor de língua portuguesa da rede pública da cidade de São Paulo. Numa segunda etapa, fez uma investigação qualitativa com quatro professores sobre sua formação leitora, três dos quais são "leitores literários". Os quatro sujeitos tinham um nível socioeconômico baixo na família de origem, pais e mães pouco escolarizados e pouco material impresso em casa. Em suas conclusões, a autora aponta que a existência de uma ética do correto e da disciplina na família de origem foi determinante para o êxito escolar dos sujeitos, e que a presença de figuras marcantes do ponto de vista das relações com a leitura e com os livros no âmbito familiar e escolar foi fundamental para seu desenvolvimento como leitores literários.

Oliveira avalia que a simples presença de capital cultural objetivado na família não foi suficiente para sua apropriação. Para que acontecesse a transmissão de disposições que conduzissem ao êxito escolar e a práticas de leitura, foram necessárias configurações 
familiares que possibilitassem a transmissão de um certo desejo pelo conhecimento e pelo saber. Tal desejo não adveio do fato de a família dispor de capital cultural incorporado ou de os pais serem leitores ou terem mais escolaridade, mas pareceu residir em um interesse pela cultura de modo geral. Esse interesse não esteve necessariamente voltado à cultura escrita, mas pode aparecer nas práticas da própria cultura oral, como é o caso de um avô que contava narrativas à neta. Em suas palavras, "não se trata de uma herança de hábitos específicos, mas de uma 'faísca' de desejo pelo conhecimento" (OLIVEIRA, 2008, p. 179). A metáfora da faísca indica curta duração de tempo. Sendo assim, pergunto-me se podem o desejo de saber e, de modo mais genérico, a constituição leitora, ser desencadeados por um contato raro e relativamente breve com um mediador mais experiente ou se o contato deve mais prolongado e constante.

Entre as figuras marcantes do ponto de vista da leitura, dois dos três leitores literários pesquisados por Oliveira relataram ter se identificado com ao menos um professor no ensino básico e outro na faculdade, professores esses com os quais desenvolveram relações fecundas do ponto de vista intelectual e mais especificamente do desenvolvimento de práticas de leitura literária. O mesmo aconteceu com a terceira leitora, mas apenas na faculdade.

Por um lado, o estudo de Oliveira aponta para a importância de ambos os contextos o familiar e o escolar - para a formação leitora dos sujeitos. Por outro, ao indicar a importância que os docentes do Ensino Superior tiveram - especificamente na faculdade de Letras - para a formação dos sujeitos, aponta para a precariedade da formação leitora na escola básica, e seu conseqüente adiamento. Dá-se, assim, uma constituição leitora mais tardia.

Pergunto-me se o mesmo teria se dado com os jovens leitores literários participantes de pesquisa. Teriam eles se constituído leitores literários depois de deixar a escola? Pode a formação leitora ser adiada para uma etapa posterior ao encerramento da escola básica e, ainda assim, acontecer? Se sim, em que âmbitos? Ou teria a constituição leitora se dado de modo concomitante à freqüência à escola?

Para os adolescentes e jovens das camadas populares, a inserção no mercado de trabalho formal ou informal dá-se freqüentemente antes do encerramento da escolarização básica. Para muitos jovens, os três anos de Ensino Médio são “tempos urgentes”, porque são, “os últimos momentos que possibilitam experimentar a condição juvenil conforme a definiu a modernidade: a vida entre os pares, a troca de afetos, a intensa sociabilidade, os espaços importantes para o exercício do lúdico e o lazer” (SPOSITO, 2008, p. 87). 
Diante da urgência em viver a juventude, terão os jovens, alguns dos quais já trabalhando durante o ensino médio, disponibilidade para se constituírem leitores? Ou, nos termos de Soares (no prelo), conseguirá a leitura - seja de entretenimento, seja literária competir com as atividades da sociabilidade, do esporte e do mundo midiático?

Com o encerramento da escolarização básica e a (tentativa de) inserção no mundo do trabalho, e, em alguns poucos casos, a freqüência concomitante a cursos de graduação privados noturnos, terão os jovens disponibilidade para o desenvolvimento tardio de práticas de leitura não funcional?

Suponho que a resposta, ainda que parcial para esse conjunto de perguntas se relaciona, conforme explorarei no capítulo de análise dos dados, ao menos no universo dos sujeitos pesquisados neste estudo, com a frequiência à escola. Embora a oferta educativa tenha provavelmente tido caráter muito precário e pouco significativo, imagino que algum papel a escola teve, dando aos sujeitos ao menos alguns instrumentos mínimos de acesso à cultura letrada e propiciando o contato com outros leitores. Imagino ainda que outros âmbitos - para além da família e da escola - interpenetrem-se com estes, havendo uma associação de fatores que tenham contribuído para a constituição leitora: acesso a material impresso, oportunidades de leitura, contato com mediadores leitores (não necessariamente professores) etc.

\subsection{Para além das categorias macro-sociais: a singularidade humana em foco}

Quando se tenta explicar a instigante existência de sujeitos das camadas populares que escaparam ao caminho que lhes parecia destinado de não sucesso escolar, de não acesso a determinados bens culturais - ou, no caso da pesquisa, de não formação de leitores em função de todas as barreiras que lhes foram impostas - muitas são as afirmações possíveis. As explicações dadas pelos próprios leitores, por seus professores e familiares, enfim, pelo senso comum, são freqüentemente de ordem inatista. Alguns leitores dizem: "Eu sempre gostei de ler e não sei de onde vem isso, porque na minha família ninguém lê. Acho que eu nasci assim". Os pais, por sua vez, podem dizer a respeito de seu filho algo do tipo: "Ah, ele puxou o meu avô, que sabia ler e até ensinava as crianças da época dele”. O professor às vezes afirma: "Essa menina sempre foi um prodígio, assim, muito inteligente, muito esperta. Ela tem um talento incrível". E freqüentemente ouvimos, mesmo de pessoas muito escolarizadas, algo do tipo “Ah, esse menino tem um QI acima da média”. 
Um segundo gênero de explicação diz respeito ao mérito do sujeito. Esse tipo de discurso é freqüentemente veiculado pelos meios de comunicação de massa, em reportagens e programas que enaltecem o esforço e protagonismo do indivíduo, com chamadas do tipo "Fulano é gente que faz", as quais, por suas vez, suscitam comentários do gênero: "Quando a pessoa quer mesmo e se esforça, ela consegue". Nesse tipo de fala, imputa-se ao indivíduo toda a responsabilidade por seu sucesso escolar ou não, por sua formação leitora ou não, tirase completamente de foco qualquer condicionante estrutural e exime-se o Estado e a sociedade de modo geral do exercício de qualquer papel.

Por outro lado, explicações sobre o fracasso escolar e a não formação de leitores nos meios populares costumam ser de ordem ambientalista. Arrolam-se vários obstáculos à escolarização e à formação leitora que levam a crer na impotência da escola e do professor como agentes de letramento. Muito comumente, culpabiliza-se a família pobre, citada entre tais obstáculos. Diz-se que não há práticas de leitura na família, a qual, por ser majoritariamente matrifocal, seria desestruturada, que não valoriza a escola e não respeita o professor. Concordo que o fato de não haver práticas de leitura na família, como mostram pesquisas quantitativas como a Retratos de Leitura no Brasil, citada anteriormente, os estudos de Patto (1991) e tantos outros, desfavoreça a formação de leitores. Porém, com Charlot (2005) e Lahire (1997), desconfio da idéia de que, de modo geral, a família pobre desvalorizaria a escola.

Embora não trate especificamente de explicações possíveis para os êxitos na formação de leitores, o estudo de Rego $(1994,1998)$ traz contribuições à pesquisa, pois analisa a presença de diferentes tipos de discursos nas falas dos agentes privilegiados de letramento: os professores. Na pesquisa realizada, solicitou-se a eles que explicassem a origem das diferenças individuais entre seus alunos a partir da questão "Cada pessoa tem características próprias e diferentes modos de ser e de pensar, capacidades, valores, comportamentos etc. Qual seria a origem dessas diferenças?" De uma amostra de 172 professores, 14,5\% atribuiu a origem da singularidade humana a fatores internos (dons, aptidões, caráter, destino, sorte, composição genética), 20,9\% atribuiu-a exclusivamente a fatores externos (as pressões do meio) que moldam o indivíduo inexoravelmente e 50\% da amostra atribuiu-a a uma justaposição de fatores inatos e adquiridos ${ }^{29}$. Tal justaposição sugere uma somatória de explicações inatistas e ambientalistas, o que redunda numa concepção de dupla determinação

\footnotetext{
${ }^{29}$ A somatória das percentagens não corresponde a 100 porque parte das redações dos professores eram incompreensíveis e tiveram de ser desconsideradas.
} 
do indivíduo ainda tão presente nos meios educacionais (REGO, 1994, 1998): “o sujeito nasceu burro e pobre".

Essas visões dos professores sobre a origem da singularidade humana sugerem determinadas concepções de homem e de mundo, às quais subjaz a idéia que o professor faz do aluno e da possibilidade ou não de aprendizagem e transformação desse indivíduo. Em outras palavras, elas revelam qual é o papel da educação na opinião desses professores. Tanto posições inatistas quanto ambientalistas (e também a justaposição dos dois tipos) parecem eximir a escola e o professor de seu papel de favorecer o desenvolvimento humano, em especial quando se trata de crianças das camadas populares:

\begin{abstract}
se na abordagem inatista os problemas relativos ao fracasso e à evasão escolar são de exclusiva responsabilidade do aluno, nessa perspectiva [ambientalista] o quadro se inverte. As causas das dificuldades do aluno são atribuídas ao universo social, como a pobreza, a desnutrição, a composição familiar, ao ambiente em que se vive, à violência da sociedade atual, à influência da televisão etc. Parece que em ambos os casos a escola se isenta de uma avaliação interna e não se vê como promotora, ainda que não exclusiva, do fracasso (ou sucesso) escolar [...]. Ela se vê, assim, desvalorizada e isenta de cumprir o seu papel de possibilitadora e desafiadora (ainda que não exclusiva) do processo de constituição do sujeito do ponto de vista de seu comportamento de um modo geral e da construção dos conhecimentos (REGO, 1998, p.65).
\end{abstract}

Rego ressalta que o ideário dos professores pesquisados é reflexo não apenas das crenças do senso comum, mas também da literatura utilizada em sua formação prévia e contínua $^{30}$, que trata de maneira vaga, contraditória ou conservadora a constituição humana.

É justo supor que, da mesma forma que acontece com as diferenças individuais, os discursos correntes para explicar os casos singulares de formação leitora nos meios populares na sua maioria teriam um caráter inatista ou ambientalista (ou duplamente determinista quando as duas visões aparecem justapostas). Uma quarta possibilidade de explicação é a de que a formação leitora de alguém se deve a seu próprio esforço, numa lógica meritocrática. Todas essas visões implicam acreditar pouco na possibilidade que a escola e o professor têm de mediar a leitura e formar leitores.

Ora, a perspectiva histórico-cultural do desenvolvimento humano, que a minha pesquisa adota, caracteriza-se justamente por sua abordagem genética ${ }^{31}$ forte, ou seja, por

\footnotetext{
${ }^{30}$ Durante a pesquisa, Rego dedicou-se à análise (incipiente e exploratória, sem ambições conclusivas, conforme informa a própria autora) dos livros de psicologia adotados em cursos de formação de professores, como magistério e pedagogia, com interesse de perceber que tratamento dão à questão da origem da constituição da singularidade humana.
} 
imprimir muito valor ao papel do outro, do signo e da cultura como mediadores da relação do sujeito com o mundo. Em tal perspectiva, a educação, a escola e o professor assumem um papel fundamental (REGO, 1995, 2003).

Inspirado nos princípios do materialismo histórico e dialético (Marx e Engels), Vygotsky considera o desenvolvimento humano não como resultado do amadurecimento de estruturas inatas e nem como mero resultado das pressões ambientais. Sem desprezar a base biológica fundamental da espécie humana, em sua perspectiva, o desenvolvimento é entendido como o processo de apropriação ativa e dialética pelo homem da experiência, saberes e hábitos, constituídos historicamente pelas gerações, através da mediação simbólica (REGO, 1995).

No contexto da discussão dessa aposta na escola como potencializadora do desenvolvimento humano considerado de modo geral, é interessante pensar a sociologia bourdieusiana da educação, a qual traz um retrato cético da possibilidade de acesso aos bens culturais pelos indivíduos das classes populares por meio da escola. Para Bourdieu, a escola tem uma função de conservação social, de manutenção dos privilégios das classes dominantes e "o sucesso excepcional de alguns indivíduos que escapam ao destino coletivo dá uma aparência de legitimidade à seleção escolar, e dá crédito ao mito da escola libertadora [...], fazendo crer que o sucesso é uma simples questão de trabalho ou de dons" (1998, p. 59). Cabe ressaltar que é justamente nesse risco de fazer a apologia do sucesso da exceção que não quero incorrer ao me dedicar ao estudo dos casos raros (como o de Ferréz) de sujeitos que logram romper a barreira de acesso à literatura. O que desejo é, da perspectiva do paradigma histórico-cultural do desenvolvimento, verificar que interações, que mediações, que relações sociais com outros sujeitos, com a leitura, com os objetos da cultura (dentre os quais estão os vários portadores de texto) contribuíram para a constituição de leitores literários entre os indivíduos que "escapa[ra]m ao destino coletivo" de não formação leitora.

A opção pela expressão constituição leitora em oposição a formação leitora é proposital e reflete dois de meus posicionamentos. O primeiro deles é que considero - e nem poderia ser diferente - que, a despeito da recente expansão da escolarização, o Estado brasileiro de modo geral não tem propiciado uma boa formação de leitores (SOARES, 2004; CUNHA, 2008), seja porque não possibilita a imersão em ambiente de letramento, seja porque a oferta educativa tem baixa qualidade (SPOSITO, 2008), seja porque a escola faz uma fraca difusão da literatura (SOARES, 2004; PIETRI, 2007; CUNHA, 2008;

\footnotetext{
${ }^{31} \mathrm{O}$ adjetivo genético $(a)$ aqui utilizado relaciona-se a gênese, a desenvolvimento. Não deve ser compreendido como derivado de gene, nem deve ser vinculado à idéia de herança genética.
} 
ZILBERMAN, 2003), conforme discuti no primeiro capítulo. O segundo deles é a perspectiva histórico-cultural que a presente pesquisa adota de não acreditar na completa sujeição do indivíduo às forças do meio, de defender que, no processo de apropriação da cultura, “o indivíduo, ao mesmo tempo em que internaliza as formas culturais, as transforma e intervém no seu meio" (REGO, 1995, p. 26). Em outras palavras, a pergunta que faço é: por que (e como) alguns indivíduos, a despeito de uma fraca ou inexistente formação leitora pela família e pela escola, constituem-se leitores que fazem não apenas a leitura funcional, mas também a de entretenimento e a literária?

A sociologia da educação de Bourdieu, conforme esclarecem Nogueira e Nogueira, "tem o grande mérito de ter fornecido as bases para um rompimento frontal com a ideologia do dom e com a noção moralmente carregada de mérito pessoal” (2006, p. 121), inviabilizando que se analise as desigualdades escolares como resultado das diferenças naturais entre os indivíduos, visão essa que se coaduna com a perspectiva histórico-cultural da presente pesquisa. É arriscado afirmar que Bourdieu conceberia de maneira determinista as relações entre os indivíduos e sua posição no espaço social. Ao invés disso, é melhor considerar, conforme fazem Bernard Charlot (2000) e Bernard Lahire (1999), que "a perspectiva de Bourdieu foi constituída tendo como foco a escala macro e que, portanto, se mostra insuficiente como referencial de análise no plano individual ou subjetivo" (NOGUEIRA e NOGUEIRA, 2006, p. 113-114).

Charlot critica Bourdieu por dar pouca atenção aos sentidos ou significados diferenciados que os indivíduos conferem à realidade, sentidos e significados esses que podem levá-los a agir de modo diverso frente às mesmas condições objetivas. Refletindo sobre as teses de Bourdieu a respeito de como se dá a reprodução na escola, Charlot analisa os limites que as teorias do habitus $^{32}$ e do capital cultural apresentam para a compreensão dos percursos escolares. O autor concorda, sim, que "o sucesso escolar supõe representações e práticas que correspondem ao habitus dos dominantes, e não ao dos dominados" (CHARLOT, 2005 , p. 39) e os trabalhos empíricos de sua equipe de pesquisadores, sim, "confirmam a importância das formas de ordenamento e de categorização do mundo e confirmam igualmente que essas formas não são as mesmas em todos os meios sociais” (Idem, p. 40). Porém, faz-se necessário: por um lado, "compreender como se constroem essas disposições psíquicas socialmente estruturadas, isto é, explicar o próprio habitus"; e, por outro, compreender o que chama de "êxitos paradoxais", ou seja, os casos de crianças dos meios

\footnotetext{
${ }^{32}$ Nas palavras de Charlot, "o habitus é o conjunto de disposições psíquicas socialmente construídas que funciona como matriz das representações e das práticas do indivíduo" (2005, p. 39).
} 
dominados que obtêm sucesso na escola e aqueles de crianças de famílias dominantes que fracassam (Ibid., p. 40).

Os conceitos de capital cultural e simbólico apresentam dificuldades, em especial no que diz respeito à metáfora da herança: "não se herda um capital cultural da mesma forma como se herda um capital financeiro ou imobiliário". Por um lado, "os pais não legam esse 'capital' cultural, ao contrário, eles têm muito trabalho para construir a relação com a cultura de seus filhos". Por outro, não basta que as crianças da classe dominante esperem a "herança cultural para vencer na escola, é preciso estudar, e estudar muito" (Ibid., p. 40).

Em suma,

não se pode contar apenas com uma análise da sociedade em termos de posições sociais, é preciso analisar também as atividades ${ }^{33}$ que os indivíduos desenvolvem nela para conquistar, para manter, para 'transmitir' essas posições e é preciso considerar também [...] o sujeito na singularidade de sua história e as atividades que ele realiza - sem esquecer, no entanto, que essa história e essas atividades se desenvolvem em um mundo social, estruturado por processos de dominação [...]. O indivíduo não se define somente por sua posição social ou pela de seus pais; ele tem uma história; passa por experiências; interpreta essa história e essa experiência; dá sentido (consciente ou inconscientemente) ao mundo, aos outros e a si mesmo. Em resumo, é um sujeito indissociavelmente social e singular. E é como tal que se deve estudar a relação com o saber (Ibid., p.40)

Charlot (1996, 2000), enfatizando a necessidade de se estudar o sentido que os indivíduos atribuem a sua escolarização, propõe que se estude as singularidades das histórias escolares e o significado e o sentido que o aprender tem para o aluno. O sociólogo vem se dedicando ao estudo do que intitulou relação com o saber, a qual é constituída

do conjunto de relações que um indivíduo mantém com o fato de aprender, com o saber, com tal ou tal saber ou 'aprender'. Essas relações variam de acordo com o tipo de saber, com as circunstâncias, não apresentando uma perfeita estabilidade no tempo. Assim, o indivíduo está envolvido em uma pluralidade de relações com o(s) saber(es) (CHARLOT, 2001, p. 22).

Embora a relação dos alunos com o(s) saber(es) e com a escola não seja a mesma nas diferentes classes sociais e a despeito de os alunos das camadas populares terem mais

\footnotetext{
${ }^{33}$ Interessante ressaltar que a noção de atividade para Charlot se coaduna com a de Marx e de Vygotsky: "A sociedade é também um conjunto de atividades [...]. Se deve analisar a sociedade em termos de atividade, de práticas; desse ponto de vista, a obra de Vigotski, retomando a idéia de práxis de Marx, é importante [porque] As atividades são socialmente definidas, mas são também atividades de um sujeito. [...] Isso significa que se deve canalizar essas atividades também na vertente do sujeitos [...] A noção marxista de práxis é muito importante porque diz que o homem está mudando o mundo pelo seu trabalho e, ao mudar o mundo, ele muda a si mesmo. Ele está se formando através da ação de transformar o mundo" (CHARLOT, 2005, p. 19-20).
} 
dificuldades na escola, constatam-se "êxitos paradoxais". Para entendê-los, é preciso "compreender como se constrói uma relação com o saber que, ao mesmo tempo, tenha a marca da origem social e não seja determinada por essa origem" (CHARLOT, 2001, p. 16). Ao invés de se estabelecer uma relação causal linear, deve-se analisar a realidade a partir de processos que a constroem e não em termos de falhas socioculturais.

Charlot (2005) identificou quatro processos distintos. O primeiro deles é vivido pelos alunos que têm o habitus de estudar, os quais são raros nas escolas de bairros populares. $\mathrm{O}$ segundo processo é o da "conquista cotidiana", freqüente entre os excelentes alunos de bairros populares que dizem "Tirei uma boa nota, mas na próxima semana vai ter mais uma prova, devo tirar mais uma boa nota" (Ibid., p. 66). O quarto processo trata dos alunos que estiveram fisicamente presentes, mas nunca entraram nas lógicas simbólicas da escola. Esse é o caso dos adolescentes que se ressentem do caráter previsível e aborrecido da escola.

O terceiro processo, vivido por cerca de $80 \%$ dos alunos, caracteriza-se por estudar para mais tarde ter um bom emprego. Nesse aspecto, Charlot identificou diferenças entre as famílias populares e as de classe média quanto ao valor da escola para a empregabilidade dos filhos e quanto ao sentido do ato de estudar:

os filhos de classe média também acreditam que terão um bom emprego com
diploma. A diferença é que, nos bairros populares, para muitos alunos, o
único sentido da escola está no fato de proporcionar um bom emprego mais
tarde [...]. Os filhos de classe média conhecem o prazer do saber, o sentido
do saber por ter encontrado um sentido em algumas matérias. Em outras
matérias, fazem o mesmo que os filhos dos meios populares. O problema dos
bairros populares na França, também já verificado no Brasil, é que há uma
maioria de alunos estudando apenas para ter um bom emprego, sem
encontrar o sentido e o prazer do saber [...]: "eu não gosto da escola, mas
graças à escola vou ter um bom emprego, mas, no dia-a-dia da vida, não
gosto da escola" (Ibid., p. 67-68, grifos meus).

Se, na França, os alunos das camadas populares teriam mais dificuldades para desenvolver uma relação significativa e prazerosa com o saber, imagino que no Brasil, país cuja oferta educativa recente aos pobres teve caráter degradado (SPOSITO, 2008), e cujas desigualdades sociais são mais graves, o desenvolvimento de uma relação significativa e prazerosa com o saber de modo geral, com os diferentes saberes e com a escola seja ainda menos favorecido. Foi justamente a essa conclusão que a equipe de pesquisadores de Charlot chegou no contexto de inadequação da escola aos jovens das camadas populares:

seja porque se desconhece esse público, seja porque o professorado é submetido a condições de trabalho incompatíveis com a formação continuada e o aprimoramento pessoal, pode-se dizer que o ensino público 
brasileiro ainda não garante aos seus alunos as condições necessárias e suficientes para o desenvolvimento de uma relação pessoal significativa com $o(s)$ saber(es), tão relevante para o êxito da aprendizagem [...]. Nessa situação, a socialização do jovem no contexto escolar e as relações entre professor e aluno têm sido especialmente difíceis, com sérios problemas de disciplina e com grande falta de interesse por parte dos alunos [...]. Tudo passa como se o jovem, ao rejeitar a escola e o professor, não conseguisse estabelecer uma relação pessoal e significativa com o saber, sobretudo com o saber escolar elou intelectual (CENPEC \& Litteris, 2001, p. 33, grifos meus $^{34}$ ).

Suspeito que as questões da relação pragmática com a escola - profissão ou notas (CHARLOT, 2001) sejam agravadas no contexto do ensino médio, período em que o grau de desinteresse pela escola é tamanho que os alunos freqüentemente fazem o mínimo possível para não caracterizar a deserção (SPOSITO, 2005).

Em investigação realizada pelo Centro de Estudos e Pesquisas em Educação (CENPEC) e pelo Instituto de Pesquisa e Assessoria em Linguagem (Litteris) com 72 alunos (de 13 a 17 anos) de escolas públicas de três regiões de baixa renda da cidade de São Paulo, com o objetivo de conhecer "o lugar do saber na vida dos jovens de camadas populares, compreender suas experiências relacionadas à aquisição de saberes e o papel da escola nesse contexto" (2001, p. 34), os jovens mencionaram raramente a escola como um local de aprendizagem e conferiram pouco valor ao aprendizado de conteúdos curriculares. Para os pesquisadores,

talvez o pouco valor que os jovens conferem ao aprendizado de conteúdos curriculares não seja resultante de seu "desinteresse", e sim de sua dificuldade de encontrar um "sentido" para aquilo que os professores ensinam; sentido esse que estaria presente se, por exemplo, em uma aula de português, ao ler um texto literário ou jornalístico com os alunos, o professor não se limitasse a trabalhar apenas a forma escrita, mas também abordasse o conteúdo tratado e sua relação com o contexto em que foi produzido e com as próprias vivências concretas dos jovens (Ibid., p.47).

O espaço escolar foi evocado pelos jovens "principalmente como um lugar de pouco apoio e de fracas referências positivas, a não ser quando considerado como um meio para se obter uma profissão" (Ibid., p. 47). Em oposição ao papel pouco relevante da escola, a pesquisa indicou a importância da família na educação do jovem:

o que salta aos olhos é um jovem circunscrito ao espaço familiar em seu cotidiano; e nesse universo, a mãe - ou a figura que ocupa seu lugar reinando soberana, secundada por pais, avós, irmãos e outros parentes. A

\footnotetext{
${ }^{34}$ Os textos dos pesquisadores do CENPEC e do Litteris foram escritos principalmente por quatro autores: Regina Maria Hubner, Márcia Padilha, América Marinho e Egon Rangel.
} 
religião, apesar de pouco mencionada de forma explícita, está presente nas referências familiares e culturais. Não há regras ou valores dessa ou daquela crença, mas existe uma moral talvez "ecumênica", de tom próprio, cujo viés é a família [...]. Essa moral aparece, se assim podemos dizer, como uma lei ou lição materna. [...] Não existe revolta ou desejo de livrar-se dessas regras, mas uma adesão afetiva aos valores a que se referem. [...] Esse quadro geral revela uma face pouco conhecida da privação: o jovem contando apenas consigo mesmo e com as lições familiares que fizeram dele o que ele julga ser. A escola, a sociedade, a vida pública, enfim, podem ser vistas, nesses auto-retratos dos jovens, tais como são para eles: omissas e ausentes, mas muito desejadas, em especial nos momentos em que o respeito e o diálogo parecem possíveis, como no caso dos poucos 'professores legais' mencionados (CENPEC; Litteris, 2001, p.48-49).

Os estudos realizados por Charlot e sua equipe tanto na França quanto no Brasil apontam para uma relação pragmática com a escola - a garantia de um emprego melhor - e para uma relação com o saber desprovida de sentido, entre a maioria dos alunos dos meios populares. Isso torna, por um lado, a constituição de leitores literários ainda mais improvável. Por outro lado, instiga a investigação dos percursos desses jovens. Além disso, leva a questionar que, se a família e a escola, por razões diferentes (família com baixa escolaridade, não imersão em ambiente de letramento, fraca difusão da literatura pela escola, falta de sentido na relação com o saber), não favorecem a formação de leitores, em que outros âmbitos ela teria acontecido? Nas instituições religiosas? No grupo de pares (grupo de estilo, militância)? Na biblioteca?

Lahire (1997), investigando como famílias aparentemente desprovidas do capital cultural valorizado pela escola engendram crianças que têm os melhores desempenhos nessa instituição, concluiu que só é possível compreender os resultados escolares quando se reconstrói a rede de interdependências familiares por meio das quais se possibilita que a criança atenda às exigências escolares. Ou seja, quando, ao invés de nos centrarmos sobre um fator explicativo dominante (como, por exemplo, o superinvestimento escolar, o caráter militante ou o autodidatismo da família, a intervenção afetiva, etc) levamos em conta que as “combinações entre as dimensões moral, cultural, econômica, política, religiosa podem ser múltiplas, assim como podem ser diferentes os estilos de "sucesso"” (Ibid., p. 31).

Ao descrever as configurações familiares, Lahire considerou cinco temas: as formas familiares da cultura escrita; as condições e disposições econômicas; a ordem moral doméstica; as formas de autoridade familiar e as formas familiares de investimento pedagógico. Quanto à ordem moral doméstica, outorgar muita importância ao bom comportamento, e ao respeito à figura do professor constitui um modo de as famílias das 
classes populares ajudarem os filhos na vida escolar, já que não conseguiriam auxiliá-los nas tarefas. Nesse aspecto, a questão da omissão parental frente à escola é um mito.

No que concerne às formas familiares da cultura escrita, Lahire pesquisou as diferenças entre as famílias quanto à freqüência de práticas de leitura e escrita, quanto às concepções dos atos de leitura e escrita e às sociabilidades em torno do texto. Concluiu que o essencial não era haver ou não materiais de leitura ou pessoas com maior escolarização, mas práticas efetivas de leitura e escrita, e sua natureza positiva ou negativa. Em outras palavras, o mais relevante era o fato de a criança presenciar ou não atos de leitura (como os pais ou outros mediadores lendo livros, revistas ou jornais), o que emprestaria a esses atos um aspecto natural (assim, para a criança, tornar-se adulto como o pai ou a mãe significaria tornar-se leitor) e o fato de a criança associar tais atos com uma experiência difícil e dolorosa ou, ao contrário, natural e prazerosa (como, por exemplo, o prazer proporcionado pela leitura de histórias por um mediador mais velho para as crianças).

Esse aspecto "natural" da leitura da qual fala Lahire guarda semelhanças com as características do processo de constituição leitora da criança pequena, conforme descrito por Smolka, segundo a qual a leitura seria algo não ensinado explicitamente, mas que a criança aprende nas relações sociais: "como se lê, para que se lê, o que se pode e não se pode ler, quem lê, quem sabe, quem pode aprender, são procedimentos implícitos, não ensinados, mas internalizados no jogo das relações pessoais" (1989, p. 34).

Algo que chama a atenção na pesquisa de Lahire (1997) é que ele se foca tanto na família que parece desconsiderar que a escola não pode ser tratada como algo totalizador e homogêneo, conforme alerta Rego:

embora freqüentemente a escola seja tratada como algo genérico e a escolarização e seus impactos como um processo homogêneo, na verdade, [...] por trás dessa aparente unidade, se esconde uma multiplicidade de experiências que propiciaram uma pluralidade de trajetórias, sempre únicas e não lineares, e, por esta razão, tão complexas (2003, p. 350).

Tendo por base a perspectiva histórico-cultural do desenvolvimento humano e amparada nas pesquisas de Charlot e Lahire, Rego (2003) estudou o impacto da escola na constituição do sujeito, pondo foco nas interações sociais não apenas no contexto familiar, mas também no ambiente escolar. Os seis sujeitos da pesquisa em questão tinham entre 44 e 58 anos e, portanto, freqüentaram a escola básica nas décadas de 60 e 70. Embora tivessem nível socioeconômico e graus de escolaridade muito heterogêneos na família de origem, todos os sujeitos atingiram um alto grau de escolaridade, passaram a lidar profissionalmente com a 
produção e disseminação de conhecimentos e mantêm ainda hoje grande interesse pela leitura e escrita.

Felipe e Francisco, os dois sujeitos originários de famílias pobres, são "sobreviventes", já que, contrariando as tendências da época, conseguiram completar toda escolarização básica e ingressaram no ensino superior, num contexto educativo caracterizado pela seletividade e exclusão dos mais pobres. Rego supõe que eles conseguiram romper as limitações impostas pelo meio de origem e completar os estudos em função de um conjunto de fatores indissociáveis, presentes na história singular de cada um, que favoreceram um modo particular de se relacionar com a escola, fatores esses que:

vão desde a importância outorgada à escola pela família passando pelas oportunidades propiciadas por acontecimentos imponderáveis (como o encontro e a interação com determinadas pessoas ou a participação em determinado grupo), pelas experiências proporcionadas pela escola (o tipo de professores que tiveram, o lugar ocupado na escola) (REGO, 2003, p. 378).

Para a autora,

o modo de se relacionar com a escola depende de uma série de aspectos, dentre eles, das esperanças para o futuro representadas pela escola [...], da auto-estima do sujeito (forjada muitas vezes pela família, pela escola ou por ambas), das expectativas nele depositadas e dos estímulos recebidos ao longo de sua formação (Ibid., p. 378).

A despeito da pluralidade das formas de vida familiar, o ambiente doméstico vivido por cada um dos seis sujeitos tinha alguns traços bastante semelhantes entre si e convergentes com certas exigências e injunções escolares. Apesar de os sujeitos terem, em suas famílias de origem, níveis diferentes de contato e interação com a cultura letrada, praticamente todos vieram de famílias em que a mãe, o pai ou ambos atribuíam enorme valor à escola, depositavam alta expectativa no desempenho dos filhos e faziam grande investimento pedagógico objetivando o êxito. Apoiavam e acompanhavam a vida escolar, apoio esse que variava em função dos recursos materiais e intelectuais de que cada família dispunha. Os pais dos dois sujeitos de origem socioeconômica baixa tinham completado apenas as séries iniciais do ensino fundamental e, portanto, não eram interlocutores preparados para lidar com o universo da escola. Porém, o investimento pedagógico que eles faziam era igualmente importante: esforçavam-se para garantir a assiduidade e pontualidade de seus filhos e para providenciar eles próprios a merenda e o material didático necessário, não aceitando aqueles providos pela escola, atitude que parece ter contribuído para a construção da auto-estima dos pesquisados e sido indicativa do enorme valor outorgado à vida escolar dos filhos. Do ponto 
de vista moral, havia um conjunto de preceitos éticos mais ou menos similares em todas as famílias, tais como a valorização da obediência, do bom comportamento e do autocontrole.

Especificamente quanto às formas familiares de cultura escrita, todos os sujeitos relataram algum tipo de interação com a prática da leitura e da escrita no núcleo familiar de origem. Porém, o grupo é bastante heterogêneo no que se refere à presença e acesso a suportes de texto e quanto às modalidades de uso da leitura e da escrita no âmbito doméstico. Eles tiveram, durante a infância e juventude, níveis bastante variados de intimidade com a leitura e a escrita no ambiente doméstico e, como conseqüência, oportunidades diferentes ao longo de sua formação como leitor e escritor. Para aqueles sujeitos que conviviam com pessoas de alta escolaridade, num ambiente mais sofisticado do ponto de vista intelectual, a interação com os livros era uma atividade cotidiana e independente da escola. Já para os sujeitos de origem social mais baixa, oriundos de famílias de menor escolaridade e que viviam em ambientes menos letrados, "a escola teve uma importância decisiva na sua formação como leitor, pois significou praticamente a única fonte de acesso e motivações para a prática da leitura" (REGO, 2003, p. 365-366). Praticamente para todos os sujeitos, houve também, no contexto extra-escolar, pelo menos um representante do mundo letrado, um interlocutor mais refinado de temas relacionados à cultura tipicamente letrada, que exercia o papel de incentivar e encorajar o êxito escolar dos sujeitos.

A respeito especificamente das interações nos primeiros anos de escolarização, quase todos os sujeitos lembram-se de as professoras serem exigentes, severas e relativamente distantes. Apenas um dos sujeitos - Francisco, um dos mais pobres - apresenta uma visão diferente das professoras dessa fase, ressaltando a afetividade e o comprometimento. E, enquanto quase todos se lembram do medo, do enfado ou das dificuldades que sentiam, Francisco, ao contrário, declara que tudo o que era oferecido pela escola era interessante. Tal visão pode estar vinculada ao enorme valor que a escola tinha para ele, já que representava praticamente a única chance de romper as limitações de seu meio e ter acesso ao universo de experiências e informações valorizadas socialmente.

Rego (2003, p. 387) aponta que, embora a origem social e o tipo de trabalho feito pela escola sejam muito relevantes, não podem ser considerados determinantes nem os únicos fatores do tipo de relação que o sujeito tem com a escola:

apesar de todos os sujeitos terem se submetido a um estilo educacional mais ou menos semelhante, o sentimento em relação à escola não era único. [...] $\mathrm{O}$ tipo de trabalho desenvolvido na escola e a origem social são aspectos extremamente importantes que devem ser considerados no exame das marcas 
escolares nas trajetórias individuais. Entretanto, o processo de aprendizado e desenvolvimento do sujeito e a relação com a escola não dependem exclusivamente da pedagogia adotada nem de sua classe social de origem. Nesse sentido, não é possível fazer grandes generalizações, é preciso relativizar, portanto, o poder exclusivo dos métodos ou das determinações sociais.

De fato, os dois sujeitos oriundos de famílias de nível socioeconômico baixo - Felipe e Francisco - têm formas diferentes de ver a escola. A visão de Francisco dos primeiros anos do Ensino Fundamental está fortemente vinculada ao valor que atribui à escola, o qual, por sua vez, tem relações com sua origem social pobre e rural. Sua visão é diferente daquela dos sujeitos oriundos de meios mais privilegiados. Todavia, o pertencimento a uma classe social não é capaz de determinar, por si, o gênero de envolvimento com o conhecimento nem o desempenho escolar. Felipe, apesar de ter uma origem socioeconômica tão desfavorecida quanto a de Francisco, tem uma visão mais crítica e cética da escola. Para ele, a importância da instituição nessa etapa estava relacionada não ao conhecimento e sim à possibilidade de ascensão social. Somente a partir da sétima série é que ele descobre os prazeres relativos ao conhecimento.

Pergunto-me se encontraria os mesmos tipos de resultados em sujeitos de uma outra geração, submetidos a um modelo educativo diferente, em que a instituição escola e a figura do professor não são mais inquestionáveis (DUBET, 1997; CHARLOT, 2008). Questionei-me ainda que tipo de relação os jovens dos meios populares, que tiveram acesso à escola num processo de expansão degradada da educação (PEREGRINO, 2006; SPOSITO, 2008), teriam com ela, com o professor e com a cultura letrada.

Praticamente todos os sujeitos participantes da pesquisa de Rego lembraram-se de professores que os marcaram. Quando as lembranças foram positivas, ressaltaram a qualidade dos docentes, retratados como comprometidos, "disposto[s] a conhecer, acompanhar e apoiar as necessidades individuais dos alunos", exigentes, bons conhecedores de sua matéria, e conscientes de seu papel de orientadores e mediadores entre o aluno e os objetos do conhecimento. Embora fortemente identificados com um modelo educativo hoje considerado problemático, tais professores foram descritos como profissionais competentes, "que se sentiam tão interessados quanto os alunos nos resultados alcançados” (REGO, 2003, p. 394). Segundo os sujeitos, os bons professores eram aqueles que exerciam uma boa mediação, que ensinavam, que os levavam a aprender, acima de tudo, que não os subestimavam. Em 
linguagem vygotskiana, os bons professores conseguiam incidir na zona de desenvolvimento proximal $^{35}$ de cada aluno.

Pergunto-me se o mesmo tipo de interação entre professores e alunos, marcada pelo forte envolvimento, é vivida comumente hoje nas escolas de bairros populares, num contexto de grande rotatividade de professores e diretores, que causa forte desenraizamento de ambos. A escola na qual esses profissionais trabalham hoje nos meios populares pode ser encarada como um local de passagem rumo a uma escola mais bem localizada e com melhor infraestrutura.

Nas escolas dos meios populares, em especial no segundo segmento do Ensino Fundamental e no Ensino Médio, além da rotatividade, há constante falta de professores e necessidade de recorrer aos "eventuais", que preenchem o tempo da aula com algum tipo de atividade nem sempre relacionada ao que o(s) professor(es) anterior(es) vinha(m) fazendo, até porque às vezes os registros de atividades são precários. Em tal contexto de grave descontinuidade do trabalho educativo e de desconhecimento do quanto os alunos já sabem ou não e de onde se deveria partir, chegar a incidir sobre a zona de desenvolvimento proximal parece-me uma possibilidade remotíssima.

Dos depoimentos dos sujeitos da pesquisa de Rego (2003), foi possível depreender ainda o poderoso "efeito professor" (DUBET, 1997), ou seja, uma íntima relação entre o objeto de conhecimento e o professor, para crianças e adolescentes que "psicologicamente, não estão em condições de distinguir o interesse pela disciplina do interesse por aquele que

\footnotetext{
${ }^{35}$ Conforme vimos antes, embora Vygotsky não ignore as definições biológicas da espécie humana, atribui enorme importância à dimensão social, a qual provê instrumentos, símbolos (além dos elementos presentes no ambiente humano que estão impregnados de significado cultural), os quais medeiam a relação do indivíduo com o mundo e provêem também os mecanismos psicológicos e formas de agir de cada grupo cultural. Sendo assim, o aprendizado é tido por Vygotsky como um aspecto fundamental para o processo de desenvolvimento das características psicológicas especificamente humanas e culturalmente organizadas: "é o aprendizado que possibilita e movimenta o processo de desenvolvimento" (REGO, 1995, p. 71). O autor bielo-russo distingue dois níveis de desenvolvimento: o nível de desenvolvimento real ou efetivo; e o nível de desenvolvimento potencial. $\mathrm{O}$ primeiro refere-se às conquistas já efetivadas na criança, às funções ou capacidades que ela já aprendeu e já sabe fazer de forma independente. O nível de desenvolvimento potencial também diz respeito àquilo que a criança é capaz de fazer, só que ainda mediante a ajuda de uma outra pessoa mais experiente (adultos ou outras crianças). Nesse caso, a criança chega a realizar tarefas ou solucionar problemas "através do diálogo, da colaboração, da imitação, da experiência compartilhada e das pistas que lhe são fornecidas" (Ibid., p. 72). Esse segundo nível é considerado por Vygotsky mais indicativo do desenvolvimento mental da criança do que o primeiro nível. O autor chamou de "zona de desenvolvimento potencial ou proximal" justamente a distância entre o nível de desenvolvimento real - aquilo que a criança é capaz de fazer com autonomia - e o nível de desenvolvimento potencial - aquilo que ela realiza em colaboração com outras pessoas de seu grupo social. Para Vygotsky, "o aprendizado é responsável por criar a zona de desenvolvimento proximal, na medida em que, em interação com outras pessoas, a criança é capaz de colocar em movimento vários processos de desenvolvimento que, sem a ajuda externa, seriam impossíveis de ocorrer" (Ibid., p. 74). Tais processos são internalizados passando a integrar as aquisições do seu desenvolvimento individual. O aprendizado de modo geral e, mais especificamente, o aprendizado escolar não apenas possibilitam, mas também orientam e estimulam processos de desenvolvimento.
} 
ensina a disciplina" (Ibid., p. 231). Assim, gostar do conteúdo depende fortemente de gostar ou não do professor em si.

Tamanha descontinuidade também desfavorece um "efeito professor" positivo. Nesse contexto, nas escolas mais periféricas, força-me a constatar que o contato e interação significativa com um professor deixa de estar no terreno do "provável" e entra para o âmbito do "imponderável", ou como diria o senso comum, da "sorte": o aluno pode dar a sorte de ter um bom professor por um período mais longo, com o qual se identifique.

De acordo com Rego, todos os sujeitos afirmaram ter sido bons alunos. Assim que chegavam a uma escola, sobressaíam-se rapidamente na classe e "passavam a ser queridos e valorizados, em especial por seu desempenho cognitivo e pelo tipo de participação que apresentavam em classe" (2003, p. 395). Todos se encontravam quase sempre entre os melhores da classe e nas classes consideradas mais fortes. Isso, além de representar status perante os colegas, garantia-lhes também prestígio na relação com os professores, os quais não escondiam a preferência e admiração que tinham por eles. Além de angariarem reconhecimento, esses alunos recebiam também premiações. Essa diferenciação era fruto não apenas de seu prestígio, mas também da idéia vigente na época de que, pondo-os em destaque, os professores estimulariam a competição e incentivariam os demais alunos a melhorar seu desempenho. A expectativa de desempenho depositada nesses alunos pela escola era alta e eles, para corresponder a tal expectativa, esforçavam-se para permanecer na lista dos melhores alunos.

Os sujeitos só não foram afetados negativamente pelo modelo competitivo e discriminatório adotado pela escola porque estavam sempre no grupo dos "brilhantes". Ao contrário, elevaram sua auto-estima e a confiança em sua capacidade intelectual. Mesmo que não pudessem contar com a ajuda externa de pais ou professores particulares, como era o caso dos dois sujeitos de famílias pobres, estavam convencidos de que poderiam aprender.

Assim como Grotta (2000), Rego identificou um indissociável vínculo entre cognição e afeto na trajetória escolar de seus sujeitos:

os relatos evidenciam o quanto é íntima a relação entre os domínios cognitivo e afetivo: o sentimento de verem reconhecidos seus esforços e habilidades e o afeto demonstrado por muitos professores permitiram que os indivíduos estudados se sentissem integrados e integrantes, e, principalmente, seguros de suas capacidades para aprender. Nesse sentido, o caso de Francisco [o sujeito de origem rural e pobre] é modelar, porque demonstra como o apoio e o acolhimento da criança que chega à escola podem ser vitais para a sua permanência na instituição. Isto confirma a tese de que a aprendizagem não mobiliza apenas a dimensão cognitiva mas 
também afetos, emoções e relações interpessoais e que, embora as ações da escola se dirijam, na maior parte das vezes, ao desenvolvimento do aspecto cognitivo, as dimensões cognitivas, emocionais e sociais não se separam na prática escolar. Pelo contrário, para o aluno, esses diferentes âmbitos se interpenetram e se contaminam, já que estão intimamente relacionados. (REGO, 2003, p. 398)

Dado o fato de que os sujeitos de ambas as pesquisas descreveram-se como bons alunos e dada a importância do vínculo afetivo dos professores com esses sujeitos para o desenvolvimento de tal auto-imagem, pergunto-me se as relações estabelecidas desde os anos iniciais da escolarização favoreceriam ou não a relação do sujeito com o saber e com a leitura durante toda a escolarização básica. Em outros termos, poderia alguém que teve experiências escolares não positivas no início de sua escolarização desenvolver uma relação com o saber e com a leitura posteriormente? Poderia alguém que se percebeu como um "mau aluno" tornarse leitor literário?

Ao final do estudo, Rego conclui que

os depoimentos sobre as singularidades das histórias escolares revelam a multiplicidade de experiências, a variedade de episódios marcantes, a pluralidade dos caminhos trilhados, os incidentes imponderáveis (importantíssimos, já que quebram qualquer determinismo, bem como a ilusão do controle sobre a vida - do indivíduo sobre a própria vida, ou dos pais sobre a vida dos filhos, etc.), enfim, a diversidade de fatores externos (e, portanto, culturais) que influenciaram a constituição de cada um, assim como os modos particulares apresentados por cada indivíduo de lidar com essas influências (2003, p. 412).

Os dados da pesquisa feita por Rego indicam "a dificuldade de pressupor efeitos universais e homogêneos da escolarização”. É sempre necessário levar em conta, além das características das experiências escolares que os sujeitos vivenciaram, "o conjunto de fatores que concorreram para a constituição de sua singularidade" (Ibid., p. 412).

Por um lado, a pesquisa de Rego, por apontar para a singularidade da relação entre o aluno e a escola e para aspectos que favoreceriam sua permanência na escola e o desenvolvimento de uma relação positiva e significativa com o saber e a cultura letrada, levame a crer na possibilidade dos sujeitos dos meios populares que capitalizariam mais o fato de estar na escola do que os outros se constituírem leitores. Por outro lado, a constatação de que aspectos inerentes às escolas freqüentadas há quatro décadas atrás pelos sujeitos de sua pesquisa - menor rotatividade e, conseqüente maior vínculo com o estabelecimento específico em que trabalhavam e com seus alunos, boa infra-estrutura, incluindo bibliotecas - não se fariam presentes nas escolas populares de hoje torna ainda mais intrigante a questão de como os leitores literários das famílias pobres teriam se constituído. 
Charlot (2008) ilumina a questão das mudanças na posição social e no trabalho dos professores, confrontando as injunções da sociedade contemporânea com o que vive o professor brasileiro cotidianamente na sala de aula, e conclui que ele é hoje, antes de tudo, um trabalhador da contradição. Para o autor,

o professor enfrenta contradições que decorrem da contemporaneidade econômica, social e cultural: deve ensinar a todos os alunos em uma escola e uma sociedade regidas pela lei da concorrência, transmitir saberes a alunos cuja maioria quer, antes de tudo, 'passar de ano' etc. Essas contradições, porém, não são um simples reflexo das contradições sociais; arraigam-se, também, nas tensões inerentes ao próprio ato de ensino/aprendizagem (Ibid., p. 1)

Como esclarece Charlot, não era esse o quadro até a década de 1950, quando a vida dentro da escola não apresentava fortes turbulências, já que esta não cumpria um papel relevante na distribuição das posições sociais e no futuro da criança. Naquele contexto, eventuais "contradições relativas à escola são contradições sociais a respeito da escola e não dentro da escola" e "a posição social dos professores, a sua imagem na opinião pública, o seu trabalho na sala de aula são claramente definidos e estáveis. O professor é mal pago, mas é respeitado e sabe qual é a sua função social e quais devem ser suas práticas na sala de aula" (Ibid., p.3).

Ainda de acordo com Charlot, tal configuração histórica muda completamente a partir das décadas de 1960 e 1970, quando a escola passa a ser pensada do ponto de vista do desenvolvimento econômico e social. A partir de então, "a contradição entra para a escola" por três razões. A primeira delas é que a escola se torna espaço de concorrência entre as crianças, já que é preciso tirar boas notas e ter diplomas superiores aos dos demais alunos para conseguir as melhores vagas no mercado de trabalho. Assim, as relações dos alunos e pais com a escola e os professores ficam mais tensas. A segunda é que as novas camadas sociais que ingressam para a escola "importam [...] comportamentos, atitudes e relações com a escola e com o que nela se estuda, que não combinam com a tradição e até com a função da escola" (Ibid., p. 3), apresentando dificuldades para atender às exigências quanto à aprendizagem e à disciplina. Além disso, passa a haver novas fontes de informação e conhecimento mais atraentes que a escola, em especial a televisão. A terceira das razões é que os professores passam a sofrer novas pressões sociais: já que os resultados dos alunos são importantes para “o futuro do país", os professores são vigiados, criticados. Vão se multiplicando os discursos sobre a escola, mas também sobre os professores. Os salários deles continuam muito baixos, mas "com a expansão da escola, em particular nas camadas sociais populares desprovidas das 
redes relacionais que possibilitam conseguir os empregos mais cobiçados, são cada vez mais numerosas as pessoas diplomadas e aptas a ensinar". Como resultado, Charlot avalia que "a contradição entra na escola e desestabiliza a função docente" (2008, p. 3). A sociedade passa a atribuir aos próprios professores a responsabilidade dessas contradições e até as práticas pedagógicas tradicionais são questionadas.

Para Charlot, até hoje perduram as funções atribuídas à escola nas décadas de 1960 e 1970, os pedidos que lhe são feitos e as contradições que ela tem de enfrentar. Perdura, portanto, a desestabilização da função docente. Nas décadas de 80 e 90, dá-se uma nova guinada decorrente das lógicas neoliberais, a saber: as exigências de eficácia e qualidade da ação e da produção social, inclusive no âmbito da educação; tais exigências levam a pensar o fim do Ensino Médio como o nível de formação desejável para a população e a abrir as portas do Ensino Superior a mais jovens; a ideologia neoliberal difunde a idéia de que a "lei do mercado" é o único meio de alcançar eficácia e qualidade, o Estado recua e multiplicam-se as privatizações do ensino; desenvolvem-se novas tecnologias, criando-se espaços de comunicação e informação não submetidos ao controle da escola e da família. Todas essas transformações impactam sobre a profissão docente, a qual foi "desestabilizada não apenas pelas exigências crescentes dos pais e da opinião pública, mas também na sua posição profissional (nas escolas particulares), na sua posição diante de seus alunos, nas suas práticas" (Ibid., p. 4).

A partir da constatação da desinstitucionalização (DUBET, 1997), das mudanças sofridas pela escola, da desestabilização da função docente (CHARLOT, 2008), pergunto-me se as relações com a escola e o saber conforme descritas nos estudos de Grotta (2000), Oliveira (2008) e Rego (2003), cujos pesquisados freqüentaram a escola em décadas anteriores aos sujeitos de meu estudo, seriam as mesmas que encontraria nestes.

Viana (2007) estudou casos de longevidade escolar nas camadas populares de Minas Gerais. Entre 1995 e 1996, entrevistou sete estudantes e suas famílias, com vistas a analisar a configuração de condições em interdependência que construíram trajetórias de êxito e possibilitaram que chegassem ao ensino superior. Seus sujeitos - todos alunos de graduação ou pós-graduação de universidades de renome - eram originários de escolas públicas e de famílias de baixo poder aquisitivo e baixo capital cultural, e filhos de pais que exerciam ocupações manuais. Tendo a noção de configuração social de Elias (1994) e os estudos de Lahire (1997) como principal referencial de análise, a pesquisadora voltou seu olhar para cinco pontos: os sentidos atribuídos à escola tanto pela família quanto pelo aluno-filho, as 
disposições e condutas temporais, os processos familiares de mobilização escolar ${ }^{36}$, a existência de grupos de referência exteriores ao núcleo familiar que o aluno teve e as oportunidades de escolarização que decorreram desse contato, as práticas socializadoras familiares ou outras formas de presença das famílias para a escolarização dos filhos.

Em suas conclusões, a autora apontou a existência de uma grande heterogeneidade das configurações familiares e o fato de que os traços explicativos não foram fatores estruturantes, mas "se circunscreveram num contexto de complexas interdependências com outros traços" (Viana, 2007, p. 228). Ainda assim, emergiram da análise dos dados algumas semelhanças entre os casos. Dentre tais semelhanças estão "o desempenho escolar relativamente bom e regular nas fases iniciais da escolarização", algo também apontado por Rego (2003). Mas, ao contrário do que se deu com os sujeitos de Rego, os pesquisados de Viana, após os primeiros anos do ensino fundamental, tiveram "percursos escolares marcadamente acidentados, caracterizados sobretudo por interrupções e pelo momento do vestibular, que aparece como o grande obstáculo no prosseguimento dos estudos" (2007, p 228-9).

Viana apontou também para trajetórias não-planificadas, isto é, para o fato de não haver, no ponto de partida, um projeto consciente de entrada na universidade. Ao contrário, "planos parciais foram sendo gestados, tanto pelos pais quanto pelos filhos, ao longo do tempo, a partir de sucessos também parciais, ou seja, essas trajetórias foram sendo construídas por etapas" (Idem, p. 232), isto é, "o horizonte temporal distendido, condição facilitadora de sucesso escolar nas camadas populares, não se instalou no vazio" (Ibid., p. 151). A pesquisadora indicou ainda a importância das oportunidades surgidas fora do universo familiar e os "êxitos escolares parciais, sobretudo os que se deram na escola primária"(p. 232), o que a leva a considerar que "o processo de escolarização dos sujeitos investigados trouxera a marca de uma significativa "imprevisibilidade"” (Ibid., p. 232). Articulada a essa dimensão de imprevisibilidade está a noção de "oportunidade", estreitamente "vinculada à possibilidade de apreensão de outras referências de mundo, distintas das advindas do universo familiar e, portanto, à possibilidade (de aproveitamento) de uma diversidade de experiências socializadoras" (Ibid., p. 232). Tais oportunidades, incertas no início da escolarização, tornaram-se auspiciosas no processo, porque foram altamente rentabilizadas e, nesse sentido, adquiriram significativa centralidade nos destinos escolares dos sujeitos.

\footnotetext{
${ }^{36}$ Conforme explica Viana, “o fenômeno da mobilização escolar é constituído por atitudes e intervenções práticas da família voltadas sistemática e intencionalmente para o bom rendimento escolar dos filhos" (2007, p. 236), o que implica atribuir a tais ações uma dimensão estratégica.
} 
Viana (2007) avaliou como êxito escolar não apenas notas elevadas, mas a inexistência de reprovação. Para a autora,

o êxito inicial atraiu êxitos subseqüentes, como se os sujeitos entrassem numa "lógica do sucesso". Assim, o êxito escolar inicial - mas também os intermediários - constituíram circunstâncias produtoras de sentidos, disposições e práticas que tenderam a reforçá-lo, ou seja, transformaram-se numa base importante, embora insuficiente por si só, para a continuidade dos estudos" (Idem, p. 232-3).

Embora os sujeitos de Viana (2007), que, pelos meus cálculos têm hoje entre 32 e 51 anos, tenham freqüentado a escola numa época posterior àquela dos sujeitos de Rego (2003), e embora muitos deles o tenham feito em precárias escolas rurais em salas multisseriadas, é possível encontrar semelhanças nas trajetórias dos pesquisados de ambas as autoras no que diz respeito ao caráter de imprevisibilidade ou imponderabilidade. A obra de Viana (2007) guarda semelhanças com a de Rego (2003) também quanto ao aspecto singular dos fatores que contribuíram para a longevidade escolar e quanto à importância do desenvolvimento de uma auto-imagem positiva do aluno nos anos iniciais do fundamental e à complementaridade dos aspectos cognitivos e afetivos. Porém, a leitura atenta dos depoimentos dos sujeitos de ambas as pesquisadoras indica que a maior parte dos sujeitos de Viana (2007) freqüentaram uma escola muito mais precária que aquela dos pesquisados mais pobres de Rego (2003) Felipe e Francisco -, não apenas por conta de sua localização, mas também pela precariedade da formação de alguns professores na área rural ou pelo fato de os entrevistados de Viana terem freqüentado cursos noturnos e conciliado estudo e trabalho.

Se, por um lado, os professores do início do fundamental tiveram papel importante, conforme disse acima, para a gênese de uma lógica do sucesso escolar, por outro, eles parecem ter tido papel muito menos importante no segundo segmento do Ensino Fundamental e no Ensino Médio. Lendo os depoimentos, tenho a impressão de que tal importância menor da atuação desses professores foi compensada por uma forte determinação dos sujeitos de utilizar a escola para não reproduzir as condições de existência dos pais. De fato, Viana ressalta que, embora as biografias desses universitários portem uma dimensão de imprevisibilidade, elas também supõem um auto-determinação imbatível, principalmente dos filhos. Essa autodeterminação de vencer na escola, no entanto, foi construída no processo de escolarização, "não tem existência a priori nem se funda num essencialismo intrínseco aos sujeitos" (2007, p. 235).

Em suma, poucos sujeitos no estudo de Viana (2007) apresentaram características de relação com a escola e o saber parecidos com aquelas das pesquisas de Grotta (2000), Rego 
(2003), Oliveira (2008). Para muitos, a qualidade mais precária da escola, que não favoreceu tanto uma relação significativa com a instituição e com o saber e nem o desenvolvimento de um "efeito professor" (DUBET, 1997) positivo, foi compensada pela emergência de uma lógica do sucesso escolar no início do fundamental (algo que também aconteceu com os sujeitos de Rego) e por um forte desejo de vencer na escola como forma de superar as condições de classe dos pais.

\subsection{Quando a escola inexistiu ou foi inócua: possibilidades de letramento extra-escolar}

Para compreender a moderna condição juvenil, tradicionalmente analisavam-se duas agências fundamentais para a socialização de crianças e jovens: a família e a escola. Isso não é mais possível contemporaneamente, já que os caminhos para a entrada na vida adulta se diversificam, tornando-se menos lineares e mais complexos. Para afirmá-lo, Sposito (2007) remete-se à discussão de Dubet $(1997,1998,2002)$ sobre o processo de desinstitucionalização de instituições que cuidam do outro (escolas, hospitais e serviços sociais) na França, o qual acarreta que a socialização não pode mais ser vista como aprendizagem crescente de papéis ou de jogos sociais, mas sim como o confronto do ator com uma grande diversidade de orientações, diante das quais ele é obrigado a construir por si próprio o sentido de sua experiência. Conforme esclarece Sposito, para o sociólogo francês, está em curso um processo de mutação que transforma a natureza da ação socializadora da escola, o que faz crer que parte do processo de socialização é de responsabilidade do sujeito sobre si mesmo.

Analisar apenas a família e a escola para a constituição dos jovens das camadas populares também não é possível no Brasil, país de expansão escolar recente, em que boa parte dos jovens pobres ou esteve fora da escola ou teve acesso apenas aos anos iniciais da escolarização (SPOSITO, 2007). Assim, cabe investigar a experiência juvenil sem retirá-la da esfera de influência das agências tradicionais - escola e família - que, apesar de transformadas, continuam a ser espaços formativos importantes, mas examinando também a "confluência de vários processos socializadores na experiência juvenil":

os jovens que hoje estão no sistema de ensino experimentam a condição juvenil em espaços não escolares e já adentram na instituição com essas práticas e modos de vida consolidados porque possuem alternativas e querem, certamente, preservá-las. Aqueles que não encontram fora do espaço escolar possibilidades de interações ricas nos grupos de pares, nas formas de lazer e de consumo ou na produção cultural compartilham esse universo simbólico carregado de expectativas e esperam realizá-las enquanto estudantes. Certamente constituem essas demandas desde o momento em que abandonam a infância, pois a escola não é a única agência que lhes 
oferece modelos culturais para a experiência de ser jovem. Não podemos deixar de considerar que estilos, hábitos e modos de vida são conformados também por outras agências [...], reiterando a idéia dos múltiplos espaços socializadores (SPOSITO, 2005, p. 124).

Em face do caráter inócuo ou negativo da escola para o desenvolvimento de uma relação significativa com o saber e a cultura letrada nos meios populares (CHARLOT 2001, 2005), do caráter degradado da recente expansão do ensino público (PEREGRINO, 2006; SPOSITO, 2008), e da necessidade de investigar a confluência de vários processos socializadores (SPOSITO, 2005, 2007), pergunto-me que outras possibilidades de envolvimento com a cultura letrada adolescentes e jovens teriam. Para responder essa questão, são úteis os estudos de Oliveira (1995) e Ratto (1995), apresentados a seguir, os quais abordam justamente as possibilidades de letramento em atividades não diretamente ligadas à escola.

Ainda não está claramente definida na literatura uma diferença entre formas letradas e formas não letradas de pensamento. Porém, partindo-se da idéia de que transformações culturais características das sociedades letradas teriam efeitos sobre o modo de funcionamento cognitivo de seus membros, que tais efeitos não estariam equitativamente distribuídos por todos os grupos culturais, que eles variariam em função da "modalidade de inserção dos indivíduos na sociedade e de sua interação com essas formas culturais", é possível concluir que "indivíduos excluídos de uma relação sistemática com a escrita, com a escola e com a ciência estariam também excluídos das formas de pensamento 'tipicamente letradas"”, a saber: o pensamento descontextualizado, o controle da produção cognitiva e os procedimentos metacognitivos (OLIVEIRA, 1995, p. 156).

A autora levanta, porém, a hipótese de que outras formas de atividade humana poderiam favorecer mudanças de modalidades de ação cognitiva, dentre as quais estão o tipo de trabalho que o sujeito realiza: "rural ou urbano, isolado ou coletivo, que exige planejamento e tomadas de decisão pelo próprio sujeito enquanto agente do processo ou que coloca o sujeito numa situação passiva, de realização de tarefas mecânicas e pré-planejadas por outrem etc" (Ibid., p. 157). Além do trabalho, Oliveira postula que outra forma de atividade que seria fonte de transformações cognitivas é o engajamento em atividades políticas tais como a militância em movimentos da sociedade civil, organizações sindicais, partidos etc. Tais atividades, por envolverem o indivíduo em "projetos coletivos que transcendem os dados da experiência concreta individual" (Ibid., p. 158), contribuem para o desenvolvimento de uma perspectiva metacognitiva, ou seja, que toma o real como objeto de 
reflexão e não apenas de ação. A vinculação intensa do indivíduo com algum gênero de utopia promove seu desenraizamento dos dados do momento e do espaço presentes.

Nas palavras de Oliveira:

as características do funcionamento cognitivo consideradas relevantes nas complexas sociedades contemporâneas, e denominadas 'tipicamente letradas', ligam-se sempre, de alguma forma, a atividades que favorecem a transcendência, pelo homem, das condições concretas de sua inserção no mundo. Podemos dizer, assim, que aquilo que tem sido denominado o 'modo letrado de funcionamento intelectual' não se relaciona necessariamente com o domínio das capacidades de leitura e de escrita. Os indivíduos constroem suas possibilidades de ação sobre o conhecimento enquanto objeto e de trânsito por dimensões que superam as limitações do contexto concreto da vida cotidiana seja em atividades mais diretamente ligadas ao letramento, seja em formas de trabalho que promovem ou possibilitam reflexão e distanciamento de uma rotina automatizada, seja ainda na relação intensa com projetos de transformação social (OLIVEIRA, 1995, p. 158-159).

Como a juventude é vivida pelas camadas populares como um tempo em que convivem a frequiência à escola e o exercício de alguma ocupação, pergunto-me se o tipo de trabalho desenvolvido pelos sujeitos poderia contribuir para seu letramento.

Os dados de Ratto (1995), que discute como a militância é fator de aceleração do processo contínuo de letramento do analfabeto adulto urbano, confirmam e ilustram as hipóteses de Oliveira (1995).

Ratto postula que a conscientização do não-escolarizado quanto à linguagem como lugar onde se manifesta o poder e se dá o confronto desencadeia uma consciência lingüística, consciência essa normalmente considerada uma decorrência apenas da aquisição da escrita e da escolarização. Os dados que Ratto apresenta, mostram, entretanto, que, "em situação de confronto, em que a linguagem é o instrumento principal de mediação, os analfabetos apresentam um discurso articulado em que se pode identificar a incorporação de formas típicas da oralidade letrada, transformada pela escrita" (1995, p. 277-278).

Ratto compara o desempenho lingüístico de um sujeito não alfabetizado a outro alfabetizado. O primeiro deles está numa "condição excepcional de contato com o letramento e pode ser considerado um parâmetro para a análise do desenvolvimento de uma consciência lingüística em situação não-escolar" (Ibid., p. 278). Como representante sindical, atua como mediador em situações em que vários discursos são produzidos por empresários - letrados - e por seus pares - não-escolarizados na maioria. Desempenha ainda um papel de letrado, produzindo documentos escritos, que são ditados à secretária do sindicato, a qual atua como escriba e corrige apenas eventuais problemas de concordância: "toda a organização discursiva 
é definida pelo sujeito, o qual dita as pautas de reivindicação, cartas e demais documentos, mostrando familiaridade com os jargões da prática burocrática” (Ibid., p. 279). Já no discurso do segundo sujeito, não envolvido em atividade política ${ }^{37}$, mas que é minimamente alfabetizado, não foi observado o fenômeno da incorporação de formas letradas (léxico, sintagmas etc).

A prática da linguagem escrita desenvolvida pelo líder sindical leva Ratto a concluir que "a sua linguagem em transformação e o desenvolvimento de uma consciência lingüística decorrem de um processo concomitante de conscientização de seu papel político, da sua consciência enquanto sujeito da sociedade da qual faz parte” (RATTO, 1995, p. 287).

Embora uma das características do letramento escolarizado seja a abstração do contexto imediato na compreensão e na produção de sentidos e embora não se negue o papel da escola nesse processo, para Ratto, é igualmente inegável que esse sujeito não-escolarizado exibe um estatuto discursivo letrado. A atitude política do sujeito e a sua conseqüente postura perante a linguagem são essenciais para o desenvolvimento de uma perspectiva metalingüística. Como a linguagem se torna um objeto de reflexão, configura-se uma situação de abstração do objeto e de distanciamento do contexto imediato. Não cabe, portanto, atribuir somente à escolarização o mérito pelo desenvolvimento de práticas descontextualizadas e de habilidades metacognitivas:

pode-se dizer, pois, que é a história do sujeito que determina o seu lugar na sociedade e a sua relação com a linguagem. E é justamente o modo como se dão as relações na sociedade letrada que pode ou não vir a desencadear diferentes atitudes diante da linguagem e acelerar o desenvolvimento de práticas letradas. E a ação política, entendida como militância em sentido amplo, cria as condições para uma prática discursiva que favorece a constituição do letramento no sujeito analfabeto adulto (Ibid., p. 289, grifos meus).

Levando-se os estudos de Oliveira (1995) e Ratto (1995) em conta, é possível supor duas formas diversas mas complementares de letramento, ou, nos termos de Bourdieu, de transmissão de capital cultural. A primeira delas diz respeito ao âmbito familiar: pais e mães com o mesmo grau de escolarização, mas que exerçam diferentes tipos de atividades no trabalho, ou que tenham se engajado na militância política ou religiosa, que disponham de diferentes quantidades de capital cultural, tanto na forma incorporada quanto na forma

\footnotetext{
37 As falas do segundo sujeito freqüentemente negam uma vontade política ou um desejo de se colocar em situação de confronto. Ao contrário, manifestam abnegação e conformismo: "nunca reclamei de serviço nenhum... graças a Deus..." (RATTO, 1995, p. 287).
} 
objetivada (em material impresso, como panfletos, livros etc), poderiam disseminar mais conhecimentos, fomentar mais reflexões e práticas de leitura. Em termos bourdieusianos, estaríamos diante de uma transmissão doméstica de capital cultural não visível. Chamo a atenção para o uso do verbo poderiam, o qual denota que essa possibilidade existe, mas que não suponho que haja uma correlação causal, linear, mecânica entre o engajamento dos pais em algum tipo de militância e uma maior transmissão de conhecimentos pelos pais e mães aos filhos (LAHIRE, 1999, 2008). Para que a transmissão exista, deve haver atividade de disseminação do conhecimento (no sentido de trabalho) dos pais e mães e atividade de apropriação desse conhecimento pelos filhos (CHARLOT, 2005).

A segunda forma diz respeito aos próprios sujeitos jovens leitores: indivíduos que tenham freqüentado uma escola de baixa qualidade podem ter aprimorado características de funcionamento cognitivo tipicamente letradas nos âmbitos da militância ou do trabalho, assim como podem ter tido favorecidos, nesses âmbitos, tanto o acesso a material impresso quanto a mediação de leituras.

Charlot dá pistas de um outro âmbito que, a exemplo da militância e do trabalho, pode favorecer o letramento fora da escola em si. Trata-se do grupo de estilo. O autor faz a constatação perplexa de que "jovens resistentes ou passivos frente aos saberes escolares, fora da escola podem adotar comportamentos que apresentam uma certa complexidade e que supõem aprendizagens aprofundadas" (2001, p. 17). Mostra-se ainda mais instigado com os casos de jovens que, embora possuam poucos recursos para as tarefas escolares que envolvem a linguagem, mostram-se bastante falantes em interações grupais ou na produção de raps. Tais constatações instigam o estudo das "relações com o aprender que são requeridas e mobilizadas em situações distintas" (Ibid., 2001, p. 17).

Antes de prosseguir com o raciocínio de Charlot, para clarear a noção de grupo de estilo, recorro a Abramo (1992), que estudou os grupos juvenis dos anos 80 em São Paulo, em particular os punks e darks. Conforme esclarece a autora, a idéia de estilo não se refere à noção de "estilo de vida", à proposição de estilos alternativos de vida, algo característico de manifestações juvenis desenvolvidas em outros períodos, em especial nos anos 70. Os integrantes dos grupos juvenis dos anos 80 não desenvolvem estilos alternativos de vida: continuam trabalhando ou procurando emprego, vivendo como antes, sem procurar articular uma outra rede de atividades que lhes permita sair do sistema produtivo e institucional. Mas, embora o desenvolvimento e atuação do seu estilo se mantenha na esfera do lazer e do consumo, isso não implica passividade: "a elaboração dos estilos significa a criação de espaços de solidariedade grupal que permitem a exploração de atividades distintas das 
normalmente disponíveis, abrindo campo para pesquisas e inovações culturais”. Além disso, os fenômenos não se limitam à esfera do privado nem significam somente uma forma compartilhada de usufruir o lazer e o consumo, "porque o estilo - as roupas, a música, as atitudes assumidas nas atividades de diversão - é usado para realizar uma exposição pública do grupo e das questões por eles problematizadas. Esses grupos vêm circular pelas ruas, vêm para a 'praça pública', fazer shows, mostrar-se aos outros, expor-se". O estilo é usado "para fazer uma aparição cênica, na qual uma mensagem está sendo veiculada. Eles usam o estilo como forma de comunicação, para falar de si e das questões que têm a colocar ao mundo" (ABRAMO, 1992, p. 220-221). Já que o núcleo central dos fenômenos juvenis dos anos 80 é a de uma encenação, como atuação para levantar questões e provocar reações, Abramo fala de "estilos espetaculares". Em síntese, os "estilos espetaculares" não devem ser vistos nem como meros fenômenos de consumismo, de descompasso com as questões públicas e os acontecimentos sociais, nem como movimentos de revolta ou de transformação social. Tratase da "elaboração crítica de questões relativas à sua condição e a seu tempo e significa também um esforço de expressão dessas elaborações no espaço público, esforço que implica a intenção de intervir nos acontecimentos" (Idem., p. 5).

$\mathrm{O}$ rap - Rythm and Poetry -, expressão artística e musical, difunde-se rapidamente nas ruas da periferia pobre da cidade de São Paulo, no final dos anos 80. Em conjunto com o break (dança de rua) e o grafite, constitui o movimento hip-hop, o qual, aglutinando pequenos grupos a partir dos 14 anos, aponta "outras imagens possíveis da identidade coletiva e do conflito social na cidade" (SPOSITO, 1993, p. 162). A saída da infância acontece na interação contínua com um conjunto de agências socializadoras. Na juventude, os laços com a família tornam-se mais difusos. Em muitos casos, os jovens inserem-se no mundo do trabalho antes do final da escolarização básica. A renda que obtêm, além do auxílio à manutenção familiar, oferece possibilidade de um novo tipo de consumo, em especial a partir dos 14 anos: novas indumentárias, atividades de lazer ou aquisição de discos. Por outro lado, a sociabilidade tecida pela mediação do trabalho "tende a exercer menor força na conformação da identidade jovem" (Idem, p. 165), devido ao acirramento da crise econômica e à conseqüente fluidez e precariedade das relações de trabalho. A mediação pela escola, por sua vez, "produz novo conjunto de relações marcadas pelo seu aspecto tenso e descontínuo" (Ibid., p. 165). Assim, “tanto pela ausência, como pela sua incapacidade em atender às suas aspirações, a escola tende a ocupar um espaço menor no âmbito da socialização dos jovens” (Ibid., p. 166). Nesse contexto de mudança e crise das instituições que recobrem as formas de sociabilidade juvenil 
- família, trabalho e escola -, as dimensões socializadoras do mundo da rua adquirem um novo relevo.

Para Charlot, "o que é aprendido só pode ser apropriado pelo sujeito se despertar nele ecos: se fizer sentido para ele" (2001, p. 21). Ora, um dos fatores de envolvimento do adolescente ou jovem com o rap é justamente a identificação com sua temática: já que a "a linguagem expressiva que constitui a música RAP recobre a denúncia da dominação entre as raças, da exclusão social e da marginalização dos jovens; combina, em síntese, a condição de ser negro, jovem e excluído" (SPOSITO, 1993, p. 168). De fato, "ao narrar o cotidiano da periferia e seus problemas numa poesia clara e direta, os jovens passam a se identificar, vendo nelas uma forma de elaborar as próprias experiências vividas” (DAYRELL, 2005, p. 96).

O envolvimento com o rap acaba propiciando o que poderíamos chamar de um intenso processo de letramento, com práticas cotidianas como compreensão de texto, análise de referências intertextuais e até escrita de seus próprios textos: "alguns deles se sentiram estimulados e descobriram seu potencial de escrever 'rimas', desenvolvendo por meio delas uma interpretação poética da própria condição em que viviam” (Ibid., p. 96).

Além de estimular a escrita e a análise das letras de outros rappers, a inserção no rap favorece a reflexão do sujeito. Ela propicia também sua transformação em agente de reflexão e letramento do outro, numa dinâmica que Dayrell chama de "pedagogia da palavra" que se desenvolve no interior do grupo. Assim, o grupo de estilo acaba por constituir-se um âmbito alternativo de formação e de uma certa politização, em graus variáveis de grupo para grupo:

o estilo rap estimula o jovem a refletir sobre si mesmo, sobre seu lugar social, contribuindo na ressignificação das identidades do jovem como pobre e negro. Ao mesmo tempo, o rap cria uma forma própria de o jovem intervir na sociedade por meio de suas práticas culturas, mas não significa, necessariamente, que se coloque como uma forma de resistência ou uma expressão política de oposição de classe. Ressalta-se seu sentido formativo, detectado numa pedagogia que parece se gestar entre eles. Uma pedagogia da palavra, nas letras, por meio das quais não pretendem impor uma compreensão da realidade, mas "fazer o cara pensar". Uma pedagogia em que há respeito pela diversidade, quando propõem que o outro, na condição de indivíduo, pense por si mesmo e tire suas próprias conclusões (Ibid., p. 292).

Sendo ex-alunos ou ainda freqüentadores das escolas públicas, os membros dos grupos de rap reconhecem a relevância do universo escolar num plano simbólico diferente. $\mathrm{Na}$ qualidade de espaço institucional, percebem sua importância para a utilização das dependências e instalações elétricas em reuniões e ensaios, em um ambiente caracterizado pela precariedade material. Além disso, vêem a escola como "via privilegiada de acesso aos 
alunos, realizando apresentações e debates para divulgar sua mensagem, sempre que alguma oportunidade se apresenta" (SPOSITO, 1993, p. 174). Segundo Dayrell, esses rappers "se consideram educadores de fato, transmitindo valores, posturas e perspectivas de vida para os alunos, ao contrário dos professores, que, nas palavras de seus sujeitos, "não têm paciência para isso"” (2005, p. 92-93). Parecem, assim, preencher um vácuo no abismo que existe entre, de um lado, a escola e o professor, e, do lado oposto, o adolescente e o jovem das camadas populares.

Apesar de não encontrarem na instituição escolar possibilidades concretas de assimilação do conhecimento e embora não depositem na escolaridade expectativas de ascensão profissional, os rappers

realizam uma espécie de reapropriação imaginária do universo escolar. Nessa trajetória reiteram a necessidade do rapper manter-se 'bem informado' e, portanto, valorizam uma atitude de busca daquele conjunto de saberes supostamente oferecidos pelo ensino. Escola e conhecimento se tornam importantes porque assegurariam o desenvolvimento do RAP, que depende da apropriação e do domínio de informações (SPOSITO, 1993, p. 174-175).

A respeito do estímulo à aquisição de conhecimentos e, por extensão, à leitura, interessante citar trechos de um rap não por acaso intitulado "Vamos ler um livro", do rapper Betinho $^{38}$ :

Ei, ei, cara

Mergulhe na história

Preste atenção no que eu vou dizer agora

Chega de ler besteira

Chega de babaquice

Procure se informar

Não seja o mestre da burrice

São tantos que falam merda

E isso enjoa, é um tormento

Procure ler um livro

Pois é a máquina do tempo

Milhares de livros estão ao seu alcance

Mas você não quer saber

Sua idéia é fraca a todo instante

Você só fala besteira

Não tem auto-estima, meu irmão

Procure ler um livro, a fonte de informação

[...]

Agora eu quero ouvir, todo mundo comigo:

Vamos ler um livro, vamos ler um livro

Povo da periferia, vamos ler um livro

Eu quero ouvir a maioria, vamos ler um livro

\footnotetext{
${ }^{38}$ Fonte: LOPES (2003).
} 
A relação dos rappers com o universo escolar e seu espaço simbólico é facilitada e redefinida pela constituição desses jovens como sujeitos, portadores de uma identidade comum: "deixam de ser apenas jovens moradores do bairro, alunos ou ex-alunos da escola, fragmentados, dispersos sem nenhum poder de negociação ou barganha" e passam a ser "os 'rappers' que buscam interação, grupo que compartilha uma auto-imagem não mais marcada pelo medo, pela humilhação ou pelo estigma da marginalidade" (SPOSITO, 1993, p. 175).

Ainda de acordo com Sposito, há duas grandes metas na expressão musical e no objetivo de atuação dos grupos de rap, em especial daqueles com maior vocação política: a primeira diz respeito à "questão da identidade negra, voltada para o desenvolvimento da autoestima, do orgulho de ser preto e da recusa das dimensões de dominação presentes nas relações de raças" (Ibid., p. 168); e a segunda "pode ser traduzida no esforço de informar os jovens para que estes se apropriem do conhecimento necessário para sobreviver, propiciando uma interpretação alternativa dos acontecimentos" (Ibid., p. 168), já que a mídia, em particular a televisão, seria responsável pela conformação das mentes dos jovens. Para ilustrar essa segunda meta, valho-me de mais um trecho do rap "Vamos ler um livro"39:

\author{
Mas você não quer saber \\ Só se liga em leituras pornográficas \\ Tipo revistas importadas, que vêm com loiras bem grandes na capa \\ Meu irmão, se esse tipo de coisa para você é informação \\ Se liga nas patricinhas que aparecem na Malhação \\ A televisão é uma droga que esconde a história \\ Só tem coisa pra boy, quer ver os pretos pedindo esmola
}

Nos bairros periféricos, as formas de lazer institucionalizadas ou públicas praticamente inexistem. Os jovens, entre a escola e o trabalho, passam parte de seu tempo livre numa área nas ruas, que se torna "o pedaço", local em que as informações circulam, e onde letras das músicas, fitas, discos e revistas são trocados. Também é no "pedaço" que se cantam as músicas, treina-se a performance e ocasionalmente se realizam apresentações (SPOSITO, 1993). A autora estima que, no início dos anos 90, havia mais de 1000 grupos de rap na cidade de São Paulo e avalia que a magnitude do fenômeno "não pode ser medida apenas pelo gosto musical ou pela freqüência aos bailes no final de semana", já que tal magnitude "envolve a própria experiência de criação musical, de constituição do grupo e do auto-reconhecimento na formulação de uma identidade coletiva enquanto 'rapper', que pode

\footnotetext{
${ }^{39}$ Fonte: LOPES (2003).
} 
resultar em estratégias mais ou menos organizadas de ação" (SPOSITO, 1993, p. 170). De fato,

muitas vezes, o "pedaço" no bairro pode ganhar a feição de um território, que exprime uma intervenção mais ampla e coletiva, mediante a formação das posses ou crew. Em geral, a posse integra número variado de grupos (às vezes chegam a 20 grupos com 3 a 5 membros cada) e busca ações mais estruturadas [...]. A peculiaridade brasileira residiria no seu arco mais amplo de atividades, no seu caráter político e na sua preocupação com os aspectos de caráter organizativo (Ibid., p. 170, grifos meus).

Em São Paulo, as posses estabelecem tarefas que devem ser cumpridas por seus membros. De modo geral, três objetivos poderiam ser caracterizados. O primeiro busca maior visibilidade artística, potencializando a capacidade de produção de músicas e de apresentações não restritas ao bairro. Tal procura por visibilidade "gera certa competição entre os grupos, que lutam por sua afirmação", a qual, de acordo com Toop (1991), referido por Sposito, estimularia uma postura constante de criação e de intervenção a partir de recursos e meios materiais limitados. O segundo objetivo da posse seria desenvolver ações comunitárias no interior do território compreendido pela posse. O terceiro seria intervir politicamente, com ações mais próximas daquelas típicas do movimento negro, por meio da participação em manifestações políticas como passeatas e a organização de debates e cursos (SPOSITO, 1993, p. 170-171).

A autora esclarece que, enquanto as galeras ou tribos urbanas apresentam um potencial muito conflitivo intergrupos, o rap não tem essa característica. Embora possa haver conflitos entre os rappers por causa de divergências sobre as formas de conduta, o estilo e a qualidade da produção, eles acontecem no "âmbito de uma solidariedade muito forte no interior de cada grupo e $[\mathrm{d}]$ o reconhecimento da liberdade do outro de escolher seu próprio caminho" (Idem., p. 171). Tais divergências não deixam de ser positivas, já que "algumas vezes as concepções diversas, dotadas de algum grau de antagonismo, são expressas na composição de letras cujo conteúdo estabelece uma espécie de duelo verbal agressivo entre os grupos” (Ibid., p. 171).

Segundo Sposito, em São Paulo, com o apoio dos movimentos negros, o rap tenta ter uma ação mais articulada por meio da publicação de revistas. Desenvolve ainda atividades diversas: oficinas em centros de lazer, debates em escolas e espetáculos nas ruas ou praças, promoção de cursos e conferências para integrantes dos grupos, e participação orgânica em manifestações políticas mais amplas, em especial aquelas ligadas à causa negra.

A elaboração simbólica do rap paulista não está circunscrita às fronteiras regionais ou nacionais. Ao contrário, a interação com a produção internacional é intensa. As informações e o material escrito e de áudio circulam rapidamente: “ser 'rapper' significa compartilhar esse 
universo global de significados, cujo alicerce comum se estrutura na identidade negra, independente do país de origem" (SPOSITO, 1993, p. 171). Além disso, os rappers disputam a possibilidade de entrar no circuito do consumo e da circulação de bens culturais: "lutam e empreendem ações voltadas para um público amplo, querem divulgar sua mensagem e constituir uma via alternativa de informação e conhecimento, constituindo os meios de comunicação de massa em poderosos adversários", tentando "criar uma capacidade de interpretação e de produção de significados que se contraponham à mídia”. (Ibid., p. 172).

Por outro lado, a superação de fronteiras nacionais, o caráter globalizante e a luta por interação com a indústria cultural não desterritorializam o rap. Ao contrário:

como parte essencial da produção radica-se na formulação de letras, na força da palavra que deve ser compreendida, ocorre o estímulo às experiências vividas na rede de relações mais imediatas: há um enorme apelo para a criatividade na medida em que todos os grupos se caracterizam por compor suas próprias músicas e desenvolverem seu estilo particular, de modo a distingui-los dos demais (Ibid., p. 173).

Em suma, pode-se dizer que o grupo de estilo rap, em particular o de São Paulo, é um âmbito que favorece muito o desenvolvimento de uma perspectiva metacognitiva não apenas porque incentiva a reflexão e porque proporciona o contato com um universo simbólico exterior ao bairro de cada grupo, mas também por seu caráter militante e pelo tipo de trabalho organizado que as posses desenvolvem.

Na tentativa de compreender as estatisticamente improváveis e, portanto, paradoxais, constituições de alguns leitores literários em meios populares, olhei para os dados na perspectiva da sociologia que tenta uma percepção mais fina que aquela das categorias macrossociais e da psicologia histórico-cultural, com o interesse de perceber que mediações significativas em diversos âmbitos - não apenas na família e na escola, mas também nas bibliotecas, nas instituições religiosas e nos grupos de pares, em particular, nos grupos de estilo - contribuíram para o desenvolvimento de práticas leitoras, em especial de práticas de leitura literária, conforme a acepção de literatura defendia por Soares (no prelo). Para tanto, foram essenciais as contribuições de autores que discutem a escolarização e formação leitora, as possibilidades de letramento extra-escolar, a condição juvenil, os grupos de pares e os grupos de estilo, além das pesquisas que abordam a escolarização e a formação leitora nas camadas populares. 
Capítulo 3

Metodologia 


\subsection{Objetivos da pesquisa}

A presente pesquisa utilizou a abordagem qualitativa. Ao contrário da pesquisa quantitativa, que oferece padrões gerais de análise, a abordagem qualitativa favorece um estudo mais aprofundado da interação dos sujeitos entre si, com os objetos culturais e com as agências socializadoras.

Instigada pela aparente improbabilidade de formação de leitores e, ainda mais de leitores literários nos meios populares, investiguei como se deu a constituição leitora de 13 jovens, com idades entre 17 a 31 anos. Para a definição de leitor, utilizei critério inspirado naquele adotado pela pesquisa Retratos da Leitura no Brasil (2008), que considerou leitor quem declarou ter lido um livro nos últimos três meses. Em minha pesquisa, considerei leitor quem declarou ter lido ao menos cinco livros nos doze meses anteriores à pesquisa. Foi considerado leitor literário o sujeito que declarou que ao menos um dos cinco livros lidos foi um livro de literatura ${ }^{40}$.

Esta investigação teve por objetivo dar respostas a dois grupos de questões: A) O que influenciou a gênese do interesse por ler? A freqüência de acesso a material impresso e sua qualidade tiveram algum tipo de influência? e; B) Qual foi a freqüência da interação com os mediadores leitores mais experientes? O contato foi constante, esporádico ou até mesmo único? Em que âmbito (família, escola, grupo de pares etc) e como aconteceu a mediação?

Para atingir os objetivos acima, busquei responder as seguintes questões: 1) Como e com que freqüência se deu o acesso a material impresso?; 2) Qual foi a mediação exercida pela família? 2.1) Havia práticas de leitura na família? 2.2) Qual a frequiência dessas práticas? 2.3) Que tipo de materiais e portadores circulavam no ambiente doméstico? 2.4) Quais eram as concepções $^{41}$ dos atos de leitura e escrita presentes na família? 2.5) Quem fazia a mediação de leitura? 2.6) Como e com que freqüência tal mediação era feita?; 3) Qual foi a mediação exercida pela escola? 3.1) Havia práticas de leitura na escola? 3.2) Qual a frequiência dessas práticas? 3.3) Que tipo de material circulava na escola, ou a que tipo de material o sujeito tinha acesso na escola? 3.4) Quais as concepções dos atos de leitura dentro da escola? 3.5) Quem fazia essa mediação? 3.6) Como e com que freqüência tal mediação era feita? 3.7) Qual foi a mediação exercida pelo professor de Língua Portuguesa? 3.8) Outras pessoas fizeram essa mediação, como, por exemplo, outros professores, alunos de outras séries etc? 3.9) Qual foi a mediação exercida pelo livro didático de língua portuguesa?; 4) Qual foi a mediação exercida pela biblioteca (escolar, pública, comunitária)?;

\footnotetext{
${ }^{40}$ De acordo com a acepção de literatura de Soares (no prelo), a qual inclui algumas obras clássicas.

${ }^{41}$ Ao falar em concepções, referimo-nos à natureza positiva ou negativa da leitura, ou seja, a como ela é vista pelos sujeitos e pelas pessoas com que convivem (LAHIRE, 2004).
} 
4.1) Que tipo de material circulava na biblioteca, e a que tipo de material o sujeito tinha acesso na biblioteca? 4.2) Qual a mediação do atendente da biblioteca? 4.3) Com que frequiência se deu essa mediação?; 5) Qual foi a mediação exercida por outras agências socializadoras (instituição religiosa, grupo de pares, etc)? 5.1) Como e com que freqüência se deu essa mediação?

\subsection{Planejamento do trabalho de campo}

Planejei realizar a pesquisa empírica por meio de entrevistas com 10 sujeitos leitores de literatura brasileira com idade entre 18 e 24 anos. Tais entrevistas seriam conduzidas com o objetivo de buscar as representações desses sujeitos sobre sua constituição como leitores, as contribuições da família, da escola, e de outras agências, como o grupo de pares, por exemplo. Buscaria os entrevistados em bibliotecas públicas não escolares, de acordo com os seguintes critérios: faixa etária, freqüência à biblioteca e número de empréstimos efetuados num determinado período, ter sido aluno de escola pública, habitar um bairro com baixo Índice de Desenvolvimento Humano (IDH), ser filho de pais (ou ter estado sob a responsabilidade de adultos) pouco letrados e que exercesse, profissões que não exigissem alto grau de escolarização. Havia planejado tabular os dados de empréstimos de obras, em especial de literatura, e, dessa forma, escolher os consulentes que mais liam.

Para a coleta de dados empíricos, havia planejado utilizar dois instrumentos: uma ficha para registrar alguns dados biográficos e um roteiro de entrevista.

A opção pelo corte etário - 18 a 24 anos - levava em consideração a idade aproximada de sujeitos que teriam, em tese, concluído o Ensino Médio (período durante o qual o currículo de Língua Portuguesa enfatiza o ensino de literatura). Além disso, acreditava que sujeitos nessa faixa etária teriam mais maturidade e elementos para refletir sobre seu percurso escolar. A faixa etária foi posteriormente alargada para 18 a 30 anos por dois motivos: a trajetória escolar de alguns sujeitos poderia ter sido tão intermitente que eles não teriam necessariamente encerrado o Ensino Médio aos 24 anos; e, como a pesquisa teórica havia indicado que os sujeitos que eu buscava eram raros, ampliar o corte etário aumentaria a exeqüibilidade da pesquisa empírica.

O local de recrutamento dos sujeitos foi uma biblioteca comunitária localizada num bairro da periferia de São Paulo. Tal opção deu-se em função da dificuldade de encontrar sujeitos leitores moradores da periferia em bibliotecas públicas, normalmente localizadas em bairros mais centrais. 
A elaboração do roteiro de entrevista inspirou-se na leitura de A Miséria do Mundo (BOURDIEU, 1997). Tal roteiro objetivou: reduzir a violência simbólica que a comunicação entre entrevistador e entrevistado poderia apresentar; e levar o entrevistado a realizar uma espécie de exercício espiritual, uma auto-análise provocada e acompanhada, oferecendo-lhe uma situação de comunicação tão livre de constrangimentos quanto possível. Para tanto, a exemplo do que fizeram Bourdieu e sua equipe de pesquisadores, planejei realizar encontros antes das entrevistas em si. Tais trocas anteriores permitiram que a pesquisa e a situação de entrevista fizessem sentido para o sujeito e que se estabelecesse uma relação de confiança entre entrevistado e entrevistador. Tais encontros tiveram também o objetivo de favorecer meu conhecimento prévio das condições das quais, na linguagem de Bourdieu, "o agente é produto": condições de existência e mecanismos sociais, condicionamentos inseparavelmente psíquicos e sociais associados à posição e à trajetória singulares do agente no espaço social (op.cit., 1997). Para tanto, mergulhei no universo da biblioteca escolhida, permanecendo por lá horas a fio, observando como funcionava e tentando depreender o perfil de seus consulentes.

De acordo com Bourdieu, tal conhecimento prévio permitiria improvisar as perguntas pertinentes ao longo da entrevista, as quais constituiriam "verdadeiras hipóteses que se apóiam numa representação intuitiva e provisória da fórmula geradora própria ao pesquisado para provocá-lo a se revelar mais completamente" (Ibid., p. 700). Por isso, não coube seguir um questionário pronto, fechado, com perguntas que, na ótica de Bourdieu, poderiam soar forçadas e artificiais, e que produziriam, portanto, respostas fictícias.

Interessados em pesquisar o problema da moradia, Bourdieu e sua equipe solicitaram aos pesquisados que lembrassem suas sucessivas residências, as condições de acesso a elas, as razões que os tinham levado a escolhê-las ou deixá-las, as alterações que nelas fizeram etc. As entrevistas assim concebidas transcorreram de maneira "natural", provocando testemunhos muito sinceros. Inspirada em tal pergunta central de Bourdieu, planejei guiar a entrevista sobre a constituição de leitores por uma pergunta central e aberta a respeito das obras que os marcaram. Assim, solicitei aos entrevistados que lembrassem os primeiros materiais (gibis, revistas, livros etc) que leram, aqueles que os agradaram ou não, as condições de acesso a tais materiais, os eventuais mediadores da leitura, a descrição das práticas de leitura (horários, locais), as razões para continuar a ler, quando começaram a gostar de ler, e assim por diante, trazendo-os, sem pressa, até os dias atuais.

Eis alguns exemplos de questões bastante abertas que planejei. 
Você se lembra de alguns livros que leu? Qual foi o primeiro livro que você se lembra de ter lido? Qual foi o primeiro livro do qual você gostou? Qual era a história? E como foi que você escolheu esse livro? Você escolheu ou alguém trouxe pra você? Como foi? Você se lembra quando você começou a se interessar por ler? Você se lembra como foi? Por que você acha que começou a gostar de ler? Você se lembra de outro livro, que leu em seguida? Você tem preferência por algum tipo de livro? Você acha que começou a gostar de ler um certo estilo mais que outro quando? Mais alguém que você conhecia gostava de ler? Ou era só você?

Também visando à redução da violência simbólica, planejei tentar, novamente a exemplo do que fizeram Bourdieu (1997) e sua equipe, neutralizar os efeitos da imposição da língua legítima, procurando utilizar linguagem parecida com a dos sujeitos pesquisados, atentando para a escolha de vocabulário. Além disso, optei por seguir uma linha de perguntas aparentemente menos lógica, com algumas idas e vindas nas questões.

Para a análise de dados, planejei trabalhar com o arquivo de áudio e com a transcrição das entrevistas, transcrição essa que foi feita de modo a aliviar o texto de desvios da norma culta ou tiques de linguagem que prejudicassem sua legibilidade.

\subsection{O local de coleta de dados}

No segundo semestre de 2007, fiz um levantamento longo, porém não exaustivo, das bibliotecas comunitárias na região metropolitana de São Paulo. Surpreendi-me com a grande quantidade delas, quantidade essa que dificultou a seleção de uma ou duas. De qualquer modo, tentei contato por e-mail e telefone com várias dessas bibliotecas, mas não obtive resposta alguma.

Por sugestão da Profa. Dra. Marília Pontes Sposito, os sujeitos foram recrutados e selecionados na Biblioteca Comunitária Solano Trindade (BCST) ${ }^{42}$. A docente acreditava que os leitores que procurava poderiam ser encontrados em tal biblioteca porque havia nela um controle da qualidade do acervo por seus idealizadores e gestores, os integrantes do Grupo Força Ativa.

Nas conversas por email e telefone com um dos membros do grupo juvenil Força Ativa, ele foi muito receptivo à idéia da pesquisa e me orientou a apresentar o projeto ao

${ }^{42}$ A partir de agora, para referir-nos a tal biblioteca, adotarei a abreviação BCST ou simplesmente a palavra biblioteca. 
grupo, numa reunião ordinária que aconteceria na biblioteca, no primeiro domingo de dezembro de 2007. Quando da apresentação, uma das participantes do grupo, perguntou-me que tipo de contrapartida a BCST teria por fornecer subsídios para a pesquisa. Além do retorno sobre o estudo, pediu-me a doação de livros para o acervo, algo que eu já pretendia fazer espontaneamente.

Terminada a apresentação e esclarecidas as dúvidas, recebi a permissão do grupo para conduzir a pesquisa e fui gentilmente presenteada, em nome do grupo, com um livro sobre movimentos juvenis, entre os quais o Força Ativa ${ }^{43}$.

Esse primeiro contato com os membros do Força Ativa - que, por um lado, demonstraram resistência à pesquisa e pediram contrapartidas e, por outro, presentearam-me orgulhosos com um livro sobre o grupo - ilustra a ambigüidade da relação que se desenvolveria entre mim e eles ao longo do trabalho de campo. Embora inicialmente tenha havido movimentos de hostilidade ou indiferença em relação a mim, inegavelmente, os integrantes do Força Ativa vieram a colaborar enormemente com a pesquisa, não apenas cedendo espaço físico para a realização das entrevistas, mas também indicando os sujeitos e, numa segunda etapa, até sugerindo a si próprios para ser entrevistados.

O trabalho de campo, que demandou cerca de 200 horas de dedicação, foi realizado na BCST entre dezembro de 2007 e março de 2008. Consistiu primeiramente, conforme já disse, de uma visita inicial à BCST durante uma reunião ordinária do Força Ativa para apresentação do projeto de pesquisa e solicitação de autorização para realizá-la naquele espaço. Logo a seguir, visitei a biblioteca para obter dados sobre seu histórico, forma de atuação, perfil de consulentes e acervo. Além disso, estabeleci contato informal com vários atendentes e consulentes da BCST, tentando desenvolver uma relação de confiança com eles e aprender sobre suas condições de existência.

Num segundo momento, fiz a seleção dos sujeitos e realizei quatorze entrevistas com duração média de noventa minutos cada ${ }^{44}$. Os depoimentos foram gravados em dois aparelhos do tipo MP3. Ainda assim, uma das entrevistas foi perdida, pois um dos aparelhos ficou sem bateria e o arquivo digital do outro se corrompeu, tornando-se incompreensível.

\footnotetext{
${ }^{43}$ DUARTE, Neide. Frutos do Brasil: histórias de mobilização juvenil. São Paulo: Aracati - Agência de Mobilização Social, 2006.

${ }^{44} \mathrm{O}$ número de entrevistas excedeu o que havia sido inicialmente previsto devido a meu entusiasmo com as histórias dos sujeitos. Outro motivo foi que, durante o trabalho de campo, tive a impressão de que os relatos eram muito heterogêneos e que uma quantidade maior deles facilitaria a identificação de recorrências. Só depois de algum distanciamento do campo, quando da análise de dados, é que comecei a me dar conta dos elementos que os vários depoimentos tinham em comum.
} 
Treze das referidas entrevistas foram transcritas a partir de março de 2008. Por último, retornei à biblioteca para reencontrar os sujeitos e oferecer a cada um deles um livro de sua escolha como agradecimento pela gentileza das entrevistas ${ }^{45}$.

A maioria dos depoimentos foi coletado numa saleta nos fundos da BCST, onde estava instalada uma pequena videoteca. Duas aconteceram na parte externa da biblioteca e outras duas, na residência dos sujeitos. Durante a maior parte das entrevistas, estiveram presentes apenas o sujeito e eu. Apenas em três casos houve mais alguém, o que, no entanto, acredito que não tenha prejudicado o andamento do relato.

Embora a etnia não tenha sido um critério de seleção, os sujeitos foram todos jovens negros, de ambos os sexos, com idades entre 17 e $31 \operatorname{anos}^{46}$. Certifiquei-me que os pesquisados mais jovens já tivessem completado o $2^{\circ}$. ano do Ensino Médio, o que significaria que já teriam freqüentado a escola por ao menos dois terços do período em que o currículo de Língua Portuguesa privilegia o trabalho com os clássicos da literatura brasileira.

A BCST está localizada em Cidade Tiradentes, bairro do extremo da zona leste da cidade de São Paulo. Segundo o censo demográfico de 2000, na época, Cidade Tiradentes tinha uma população de cerca de $190.000^{47}$ habitantes. Estimo que tal número seja significativamente maior agora, visto que, entre 1991 e 2000, a taxa de crescimento demográfico desse bairro foi de 7,89\% ao ano. A despeito de seu elevado número de habitantes, Cidade Tiradentes, de acordo com o próprio site da prefeitura, no item Equipamentos de Cultura e Esporte, não conta com absolutamente nenhuma biblioteca pública, casa de cultura ou centro cultural, museu ou teatro. Em 2004, seu Índice de Desenvolvimento Humano (IDH) era 0,446, ou seja, situava-se na faixa mais baixa da cidade, que vai de 0,000 a 0,500 .

No primeiro dia em que visitei a BCST, procurei-a em vão por alguns minutos. Como os jovens que se reuniriam atrasaram-se um pouco, cheguei a pensar que estava com o endereço errado. Ingenuamente, não conseguia imaginar que a lojinha comercial, sem placa,

\footnotetext{
${ }^{45}$ Inicialmente, havia pensado em doar livros para o acervo da biblioteca, conforme havia sido solicitado pela integrante do grupo. Porém, já em campo, recebi a sugestão de presentear os próprios sujeitos e assim o fiz.

${ }^{46} \mathrm{O}$ pertencimento racial não foi foco da presente pesquisa e não perguntei aos jovens como se declaravam. Alguns o fizeram espontaneamente. Para esses, adotei o mesmo critério que Raquel Souza (2009), em cuja dissertação, "em acordo com estudos sobre as relações raciais, com as perspectivas políticas do movimento negro e com os agrupamentos realizados pelo Instituto Brasileiro de Geografia e Estatística (IBGE), foram considerados negros os jovens que se definiam como 'pretos', 'negros', 'pardos' e 'mestiços'” (Idem, p. 15). Para os que não declararam espontaneamente seu pertencimento racial, adotei minha percepção.

${ }^{47}$ Fonte:http://ww2.prefeitura.sp.gov.br//arquivos/secretarias/governo/sumario_dados/ZL_TIRADENTES _Caderno19.pdf, recuperado em dezembro de 2007.
} 
ao lado de uma oficina mecânica, uma tapeçaria e dois bares, abrigava uma biblioteca. Por mais que soubesse teoricamente que as bibliotecas comunitárias lutam com precariedade para se manter, ao se falar em biblioteca, involuntariamente vinham-me à mente os edifícios das bibliotecas públicas. Tal imagem contrastou radicalmente com as instalações da BCST.

Depois de perguntar a crianças das adjacências onde era a biblioteca comunitária, retornei ao endereço que tinha. Agora, a porta de metal já estava aberta e começavam a chegar os jovens que se reuniriam. As paredes cobertas de fotos de Martin Luther King, Malcom X, Che Guevara, um desenho de Zumbi dos Palmares, um símbolo de foice e martelo, além de cartazes com campanhas de prevenção à AIDS, contra a redução da maioridade penal, em defesa das cotas raciais nas universidades e da libertação da Palestina estavam em consonância com o posicionamento ideológico e com as atividades do Força Ativa.

O Núcleo Cultural Força Ativa é uma organização juvenil que tem por objetivo promover a conscientização política, a cultura afro-descendente, a música rap e outros segmentos do hiphop por meio de eventos culturais, palestras, debates e grupos de estudo. Os ativistas do Força Ativa combatem o racismo, o preconceito contra a mulher e as violações de direitos humanos e lutam por educação pública de qualidade ${ }^{48}$.

O Força Ativa surgiu como uma posse de rappers em 1989. A princípio, focou-se na denúncia de temas relacionados ao racismo e à exploração da mulher trabalhadora. Uma de suas formas de atuação era o que eles convencionaram chamar "rap politizado". Alguns integrantes do Força Ativa faziam parte do grupo de rap "Juventude Armada", o qual iniciou, em 1995, o Projeto "Vamos Ler um Livro", inspirado na música de mesmo nome, que era apresentada nas escolas locais. Tal música discutia a importância da leitura para os rappers, como forma de informar-se, politizar-se, compreender e questionar a sociedade brasileira. $\mathrm{O}$ grupo foi agregando à sua causa pessoas que não eram do hip-hop. Deu-se assim o início da mobilização da comunidade para a criação de uma biblioteca comunitária, mais do que necessária já que as bibliotecas mais próximas ficavam em outros bairros, como Guaianases ou São Mateus. As bibliotecas escolares, por sua vez, ou inexistiam ou não permitiam a circulação de seu acervo ${ }^{49}$.

Em contato com Ação Educativa, o grupo Força Ativa foi convidado a participar do Projeto Integrar pela Educação. A parceria com o Projeto Integrar - que financiou a

\footnotetext{
${ }^{48}$ Fonte:www.forcativa.com, recuperado em abril de 2007.

${ }^{49}$ Fonte: www.itaucultural.org.br/biblioteca/download/bibliotecas_comunitarias_e populares _pdf, recuperado em dezembro de 2007.
} 
aquisição de um acervo inicial e outros materiais - e com o Instituto Brasileiro de Estudos e Apoio Comunitário (IBEAC) - que cedeu o espaço para a instalação da biblioteca - viabilizou a inauguração da BCST em $2001^{50}$.

Em 2003, o Instituto Brasil Leitor forneceu material do curso de Bibliotecário à Distância, voltado para a formação de gestores de bibliotecas, que foi estudado pelos membros do Força Ativa e por alguns consulentes da biblioteca.

$\mathrm{O}$ interesse pela biblioteca cresceu à medida que os consulentes conheciam o espaço e o recomendavam boca a boca, já que não havia recursos para sua divulgação. Em um ano, foram cadastrados 400 usuários. Em 2003, esse número atingiu 2.000 pessoas. Em 2007, o número de usuários cadastrados era 4.000.

Os usuários podem ler e pesquisar na BCST e também retirar livros, sem limite de quantidade, pelo período de uma semana. Quando as pessoas se cadastram, explica-se-lhes a história da biblioteca e suas dificuldades, de modo a conscientizá-las sobre o caráter comunitário daquele equipamento e da importância de elas contribuírem para a manutenção do acervo e do espaço. Assim, não há maiores problemas com atrasos ou não devolução dos materiais $^{51}$.

Os membros do grupo Força Ativa se revezam no atendimento aos usuários da biblioteca e no tratamento do acervo. Tais atendentes são chamados internamente de "mediadores de leitura". Há também casos de alguns mediadores que, embora não sejam membros do Força Ativa, trabalham voluntariamente na BCST por terem o desejo de contribuir para a biblioteca ${ }^{52}$. Os mediadores de leitura membros do Força Ativa normalmente promovem a reflexão dos consulentes sobre suas condições de classe, raça e gênero durante bate-papos informais no dia-a-dia da BCST. Estimulam também a leitura de obras que julgam promover um maior esclarecimento de tais condições. Em decorrência dessa reflexão, alguns consulentes passam a integrar o Força Ativa.

Os mediadores de leitura membros do Força Ativa difundem uma concepção de leitura para obtenção de conhecimento e para a emancipação do ser humano $e$ transformação social como forma de buscar conhecimento e se politizar. Acreditam que isso não se faz "lendo qualquer coisa" e que "há leituras e leituras". Assim, incentivam a leitura de autores que julgam estar preocupados com a exclusão social e suas causas históricas, com a

\footnotetext{
${ }^{50}$ Idem.

${ }^{51}$ Fonte: www.forcativa.com, recuperado em abril de 2007.

${ }^{52}$ Idem
} 
compreensão da sociedade de modo geral e do tipo de sociedade que se deseja para o futuro. Acreditam que a leitura seja uma "ferramenta de combate à ideologia dominante" e que é possível "fazer uma leitura da sociedade, entender as contradições de classe e mudar a realidade por meio da organização dos despossuídos" $"$.

Passo agora a apresentar alguns dados sobre o acervo da BCST, utilizando o pretérito imperfeito, pois ele foi reorganizado entre janeiro e maio de 2008.

Em dezembro de 2007, a BCST contava com um acervo de aproximadamente 4000 livros. A maior parte das seções (como Filosofia, História etc) da biblioteca ocupava uma única prateleira de uma das estantes de metal que abrigavam os livros. Como não foi possível ter acesso ao número de livros de cada seção do acervo, a não ser que contasse manualmente um a um, optei por contar o número de prateleiras. Quando esse número foi superior a uma prateleira, ele aparece indicado no texto entre parênteses. Assim, ao ver "Filosofia (2)", por exemplo, o leitor deve compreender que havia duas prateleiras de obras de filosofia na BCST.

O acervo estava dividido em: Artes, Africanidade, Biografia, Biologia, Coleção, Ciências Sociais, Contos e Crônicas, Direitos Humanos, Educação, Filosofia (2), Física, Geografia, História das Américas (2), História do Brasil (5), História Geral, História Medieval, História Moderna, História Contemporânea, História Oceania, História África, História Atualidades, História Europa, Idiomas, Informática, Língua Portuguesa, Literatura Brasileira (9), Direito, Literatura Infanto-Juvenil (5), Filosofia, Romance americano (13), Pesquisa, Psicologia (3), Matemática, Mulher, Romance alemão, Romance italiano, Religião (4), Romance brasileiro (9), Sexualidade (2), Saúde, TV/Rádio/Música/Comunicação, Variedades, gibis e revistas antigas. A biblioteca tinha também cinco prateleiras com obras ainda não classificadas e outras seis prateleiras com enciclopédias diversas, como Mirador, Barsa, Conhecer e Larousse Cultural, além de algumas prateleiras com livros didáticos. Havia também uma pequena e incipiente videoteca.

A BCST tinha um número considerável de obras de literatura, e, dentre as obras de literatura brasileira, a maioria era de títulos de autores canônicos. Tal levantamento preliminar foi fundamental para a pesquisa. Não haveria como dizer que um leitor lê ou não obras de literatura, e o porquê disso, se tais obras não constassem do acervo da biblioteca e se ele não tivesse, portanto, acesso a elas.

\footnotetext{
${ }^{53}$ Fonte: www.forcativa.com, recuperado em abril de 2007.
} 


\subsection{Da intenção ao ato: a coleta de dados}

O início do trabalho de campo fez-me repensar a metodologia quanto aos seguintes aspectos: a forma de seleção dos sujeitos e o critério do que se considerava ser um leitor; as estratégias de redução da violência simbólica, como a simplificação da linguagem; e o roteiro de entrevista.

Por um lado, a seleção da BCST como local de recrutamento dos sujeitos revelou-se extremamente favorável à localização dos sujeitos leitores que buscava: ex-alunos de escolas públicas, moradores de um bairro com baixo IDH, com pais pouco letrados etc. Por outro lado, a idéia de selecionar os leitores mais assíduos tabulando o número de empréstimos por eles realizados na BCST mostrou-se pouco exeqüível, já que o controle de circulação do acervo da biblioteca apresentava muita precariedade. Era realizado manualmente num calhamaço de folhas de sulfite. Tal calhamaço abrangia apenas 2007 e alguns meses estavam fora de ordem ou simplesmente faltando. Também não foi possível ter acesso aos registros de anos anteriores, que os atendentes da biblioteca não sabiam onde estavam. Posteriormente, em janeiro de 2008, o controle de circulação de 2007 se extraviaria em meio a uma reforma da biblioteca e à reorganização do acervo.

Ao manipular o registro de 2007, confrontei-me também com a falta de rigor nas anotações. Quando perseguia, no registro, o nome de alguém que havia retirado muitas obras, descobria mais tarde que a pessoa não pertencia à faixa etária eleita (apesar de, na ficha de empréstimo, a idade do consulente supostamente ter de ser anotada), ou que ela não tinha nenhum e-mail ou telefone para contato e que os mediadores não sabiam dizer onde aquela pessoa morava. Tais dificuldades, aliadas ao período exíguo de tempo em que a BCST estava ficando aberta naquela época - apenas das $13 \mathrm{~h}$ às $17 \mathrm{~h}$ - e à óbvia impossibilidade de levar o calhamaço de registros para outro local para me debruçar mais longamente sobre ele, levaram-me a abandonar a idéia de tabular dados de empréstimos para deles extrair os nomes dos sujeitos.

Assim, decidi adotar a percepção e indicação dos atendentes da BCST, internamente chamados mediadores de leitura, como parâmetro para a seleção de sujeitos. Pedi a alguns mediadores que indicassem quem eles reconheciam como leitores assíduos, em especial de literatura. A dificuldade de tal opção foi que, à exceção de uma pessoa, os mediadores mais experientes estavam empregados e não mais atuavam na biblioteca. Tal problema, contudo, foi contornado à medida que passei mais horas lá: há uma sociabilidade em torno da BCST 
que propiciou o encontro casual com alguns ex-mediadores. Uma dessas ex-mediadoras, de nome Frida, muito solícita, recomendou leitores, sem considerar se eles eram consulentes apenas ou se já tinham também atuado como mediadores de leitura ou se eram membros do Força Ativa.

As indicações feitas por Frida evidenciaram como as categorias consulente, mediador voluntário de leitura e membro do Força Ativa podiam se interpor e o quanto uma distinção entre elas poderia ser artificial na BCST: vários consulentes já haviam atuado como voluntários mediadores de leitura, independentemente de serem membros ou não do Força Ativa. Vários mediadores voluntários, antes de o serem, foram consulentes da BCST. Pareceume metodologicamente possível entrevistar tanto consulentes quanto mediadores. A partir de um determinado momento, passei também a não excluir os membros do Força Ativa.

Uma das consulentes que visitaram a biblioteca em dezembro de 2007 retirou um livro infanto-juvenil e declarou adorar ler. Questionada sobre quantos livros lia ao ano, disse-me com muito orgulho que lia cinco. Ficou evidente que, de acordo com o relato da entrevistapiloto realizada em julho de 2007, a prática de leitura não é apenas uma disposição interna, mas também está condicionada por fatores externos ${ }^{54}$. Assim, o que eu imaginara inicialmente ser o número de obras lidas por ano pelo suposto bom leitor deveria se reduzir a cinco ou seis, já que o tempo livre para ler pode ser exíguo por vários motivos. Dentre tais motivos, estão: o leitor trabalha e estuda; estuda apenas, mas toma conta dos irmãos mais novos e é responsável pelas tarefas domésticas; apenas trabalha, mas o deslocamento é longo e feito em pé no ônibus, o que impossibilita a leitura; o leitor não dispõe de um espaço físico mais reservado, mais favorável à concentração para a leitura - algo que percebi quando me informaram que alguns leitores vão à BCST em busca de silêncio.

Em resumo, o critério de seleção dos sujeitos por número de empréstimos efetuados na biblioteca foi substituído por:

a) ser reconhecido por um mediador de leitura da biblioteca como um bom leitor, um leitor literário, que lê por opção, não apenas por obrigação para atender às demandas escolares, não importando se o sujeito sempre foi apenas consulente da biblioteca, se já chegou a atuar como mediador de leitura, ou até se se tornou membro do Força Ativa;

b) declarar gostar de ler e gostar de ler literatura; e

c) ter lido, no mínimo, cinco livros nos últimos doze meses, dentre os quais ao menos um de literatura.

\footnotetext{
${ }^{54}$ Entrevista realizada com uma leitora de 14 anos, moradora do bairro de Parelheiros, no extremo da zona sul de São Paulo.
} 
Enquanto realizava as entrevistas, era surpreendida pelo campo, que se revelava muito mais complexo e instigante do que havia suposto minha pesquisa teórica. Entrevistei sujeitos que afirmaram não gostar de ler, ter dificuldades para compreender a linguagem, não compreender ou não se identificar com a temática dos clássicos da literatura brasileira, que, por outro lado, relataram que liam obras de filosofia, história e sociologia tão ou mais complexas que os clássicos da literatura; por outro lado, havia sujeitos que liam Machado de Assis, por exemplo, mas não conseguiriam ler as sofisticadas obras de ciências humanas que os primeiros apreciavam. Pareceu-me valer a pena entrevistar uma gama variada de leitores.

Quando do início da análise de dados, optei por dividir os sujeitos da presente pesquisa em dois grupos, de acordo com o que lêem e como lêem. Assim, sujeitos que afirmaram não gostar de ler, ter dificuldades para compreender a linguagem, não compreender ou não se identificar com a temática das obras de literatura brasileira ${ }^{55}$ foram alocados num primeiro grupo, denominado leitores. Já os sujeitos que afirmaram gostar de ler, não ter dificuldades para compreender a linguagem e a temática de obras clássicas da literatura brasileira foram reunidos num segundo grupo, chamado leitores de literatura.

Passo a relatar agora como efetivamente se deu a seleção dos sujeitos ${ }^{56}$.

Perguntei a Dandara - jovem membro do Força Ativa, que em dezembro atuava como mediadora voluntária de leitura às quartas à tarde, mas que já havia trabalhado lá todos os dias em anos anteriores - se, examinando os registros de empréstimos, conseguia identificar dez leitores assíduos, com idade entre 18 e 30 anos. Ela, gentilmente, fez uma lista com os nomes.

Em seguida, dado o brevíssimo tempo em que poderia permanecer na BCST, solicitei a Dandara que realizasse um trabalho ${ }^{57}$ de levantamento de todos os títulos que aqueles dez sujeitos haviam retirado durante 2007 e de confirmação de suas idades e eventuais telefones para contato. O objetivo, nessa segunda etapa, foi escolher os consulentes que liam literatura.

Depois de feito o levantamento, alguns consulentes foram descartados por não estarem na faixa etária adequada; com outros, não foi possível estabelecer contato por não terem email, telefone ou morarem relativamente longe da BCST. Os sujeitos selecionados a partir da

\footnotetext{
${ }^{55}$ De acordo com a acepção de literatura de Soares (no prelo).

${ }^{56}$ Com vistas à preservação do anonimato, todos os nomes dos integrantes do Força Ativa, dos sujeitos e das pessoas por eles citadas (familiares, amigos, professores etc) são fictícios.

${ }^{57}$ Ofereci a Dandara a possibilidade de remuneração por tal trabalho. Seguindo a lógica da contrapartida em doação de livros, que havia sido solicitada quando de meu primeiro encontro com o Força Ativa, pareceu-me justo remunerar o longo tempo que Dandara despenderia para me auxiliar na pesquisa, o que efetivamente fiz.
} 
indicação de Dandara e que, efetivamente, vieram a ser entrevistados foram: Anderson ${ }^{58}$, Beatriz, Laís, Paula e Taiko.

Também pedi a Frida - membro do Força Ativa e ex-mediadora de leitura - que me recomendasse leitores. Ela indicou vários, dos quais consegui entrevistar AK47, Malik e Zapata. Graças ao contato freqüente com Frida, acabei me dando conta de que também ela tinha o perfil dos sujeitos que buscava. O mesmo aconteceu com Dandara.

Conheci Maria e Álvares - dois outros sujeitos que vim a entrevistar - por acaso, na mesma tarde em que encontrei Frida pela primeira vez, quando passaram pela BCST. Expliquei-lhes do que tratava o projeto de pesquisa e pedi recomendação de leitores.

Maria, ao invés de indicar alguém, disse-me com entusiasmo que ela própria tinha o perfil dos casos que procurava, porque era filha de mãe não alfabetizada e gostava muito de ler.

Álvares, por sua vez, argüiu-me vivamente sobre a função social de minha pesquisa e as idéias de Vygotsky. Afirmou que gostava muitíssimo de ler literatura, porque acreditava que ela antecipa algumas idéias que já estão em efervescência num determinado período histórico e que só depois serão discutidas de modo científico. Propus-lhe, então, a realização da entrevista.

O sujeito André apareceu na BCST num dia de mutirão de reforma e organização do acervo. Enquanto tentava agendar uma entrevista com um amigo seu, que havia sido selecionado por Dandara, André interessou-se pela pesquisa, informou ter o perfil desejado e fez questão de dar seu relato naquele mesmo dia.

Marley, voluntário da biblioteca que encontrei várias vezes quando da realização de entrevistas no espaço da BCST, e que parecia me testar e hostilizar o tempo todo, acabou, surpreendentemente, oferecendo-se para também ser entrevistado.

As primeiras visitas à BCST também me fizeram rever meu pressuposto sobre a redução da violência simbólica e a linguagem a utilizar com os sujeitos. Quando realizei a já mencionada entrevista-piloto, preocupei-me muito, à luz de Bourdieu (1997), em adequar minha linguagem à da entrevistada. Naquele caso, tal adequação foi sinônimo de simplificação. Porém, no contato com os sujeitos mediadores da BCST, e com alguns consulentes, dei-me conta de que, ao simplificar a linguagem, eles poderiam sentir-se subestimados e atribuir tal atitude a um preconceito contra jovens e/ou moradores da periferia. Como valorizam o conhecimento, senti que precisaria achar um meio-termo, para, por um

\footnotetext{
${ }^{58}$ Cujo depoimento perdi por problemas técnicos.
} 
lado, não me expressar de forma que parecesse subestimá-los e para, por outro, não utilizar termos herméticos da academia. Foi necessário ter sensibilidade para ser muito simples com sujeitos que demandassem isso e ser intelectualmente instigante com os sujeitos que se orgulhassem de seus conhecimentos e de sua habilidade para embates teóricos.

A estratégia de utilizar linguagem despretensiosa ou até mesmo bem simplificada para reduzir a violência simbólica pareceu funcionar bem com seis dos treze sujeitos entrevistados: André, Beatriz, Dandara, Laís, Paula e Taiko. Porém, com um segundo grupo de entrevistados - AK47, Álvares, Frida, Malik, Maria, Marley e Zapata -, composto por sujeitos mais escolarizados e também mais politizados, a estratégia teve de ser diferente. Para esse segundo grupo, quanto mais intelectualmente instigantes fossem as discussões, mais eles se sentiriam respeitados, valorizados. Para estes, a violência simbólica residiria justamente na impressão de estar sendo subestimados.

Com esse segundo grupo, o fato de ser uma pesquisadora da Universidade de São Paulo classificava-me como privilegiada e, portanto, não digna de confiança. Houve embates anteriores às entrevistas em si, durante os quais fui questionada sobre meu marco teórico, a “função social" de minha pesquisa e o porquê de meu interesse por Cidade Tiradentes. Após tais embates é que os sujeitos passaram a concordar em conceder as entrevistas e até a colaborar com elas. Com Álvares, o primeiro entrevistado desse grupo, por exemplo, houve uma discussão teórica de cerca de uma hora, pessoalmente, no dia em que nos conhecemos, de outra hora ao telefone no dia em que marcamos a entrevista e de mais uma hora no dia da entrevista em si.

Para reduzir constrangimentos e estimular os sujeitos a falarem mais, decidi não empregar a ficha com dados biográficos e coletá-los de modo informal durante a própria entrevista. Laís, a primeira pessoa que entrevistei, informou, entrelinhas, já ao final de seu relato, que sua família era matrifocal e qual a ocupação de sua mãe com um certo constrangimento, atenuado pela relação de confiança que acredito que estabelecemos minimamente. O preenchimento da ficha antes da entrevista muito provavelmente a teria inibido.

Quando da coleta de dados, houve mudanças também no roteiro de entrevista. Ocorreu também um maior improviso de questões para vencer desafios específicos e a abertura para a pauta do leitor.

No caso do primeiro grupo de sujeitos - composto por André, Beatriz, Dandara, Laís, Paula e Taiko -, o roteiro de entrevista semi-estruturada pareceu adequado (ANEXO C). As 
entrevistas transcorreram conforme planejado: os sujeitos lembraram seus materiais de leitura e, assim, acabaram indiretamente relatando sua formação como leitores.

No caso do segundo grupo - formado por AK47, Álvares, Frida, Malik, Maria, Marley e Zapata -, foi necessário rever a pergunta central sobre os materiais de leitura que haviam lido e eventualmente fazer perguntas mais objetivas (como, por exemplo, "como você avalia o papel que a escola exerceu para sua formação como leitor?’), utilizando inclusive termos mais precisos como mediação ou acesso a material impresso. Além disso, foi necessário procurar portas de entrada distintas para cada um deles dar a seu relato um caráter mais pessoal.

Álvares, por exemplo, teorizou muito tudo o que dizia e fez inúmeras digressões. Tentou manter-se no nível de abstrações, usando um discurso politizado, o qual não era o foco da pesquisa. Como objetivava uma "auto-análise provocada e acompanhada" (BOURDIEU, 1997), meu esforço consistiu em fazê-lo voltar à sua própria biografia.

AK47 destacou-se por sua timidez e por um controle maior de tudo que dizia. Meu principal desafio foi tentar fazê-lo vencer sua reserva.

Tanto Maria quanto Frida fizeram relatos sucintos e articulados. O discurso de Maria foi mais biográfico e aparentemente mais desprovido de constrangimentos. Ela parecia já ter pensado muito a respeito de sua trajetória. Meu esforço consistiu em tentar fazê-la perceber algo em que não tivesse pensado antes. Já com Frida, tive a impressão de que se sentia constrangida e que selecionava fortemente o que queria ou não dizer. Meu desafio foi tentar fazê-la vencer esse constrangimento e não sei se tive sucesso de fato.

Malik, ao contrário de Maria e Frida, parecia não ter pensado antes sobre sua constituição como leitor. Meu esforço com ele foi fazê-lo explorar várias dimensões dessa formação. Ao final da entrevista, ele declarou-se muito feliz, dizendo que ela tinha sido um exercício interessante.

Marley pautou seu relato pelo tema da indisciplina na escola e de sua identidade racial. Meu desafio foi fazê-lo focar-se também na sua constituição como leitor.

Zapata não estava disposto a me conceder entrevista no dia em que ela aconteceu. Havia tido menos contato com ele do que com os outros entrevistados e, embora ele fosse cordial, não havia da parte dele nenhum traço de simpatia por mim. Começamos a conversar informalmente sobre leitura durante um mutirão na biblioteca, enquanto ele catalogava livros. Ele, aparentemente ao contrário do que racionalmente havia planejado, começou a falar muito generosamente sobre leitura e sua formação. Passados cerca de 10 minutos, pedi para gravar a conversa, durante a qual Zapata fez um relato bastante rico. Meu desafio com ele foi vencer sua resistência a dar a entrevista em si. 
O que houve de comum entre ambos os grupos de entrevistados é que tentei abrir espaço para digressões, para histórias aparentemente não relacionadas ao foco da pesquisa ou, em outras palavras, para a pauta do sujeito. Laís, por exemplo, entusiasmou-se muito ao contar em detalhes o enredo dos livros que leu. Beatriz e Paula desejaram falar da mãe falecida, do pai violento, dos namoros e da cidade em que moravam antes. André quis muito falar de toda a sua família. Começou pelo avô paterno até chegar à descrição das atividades profissionais de cada um dos irmãos. Conversou também sobre problemas de baixa autoestima e de conflitos com a mãe, ambos motivados pelo desemprego prolongado. Marley, conforme disse antes, pautou seu relato pela indisciplina e por sua identidade racial.

Se, por um lado, tal abertura para a pauta do sujeito fez com que algumas entrevistas se tornassem mais longas, por outro, contribuiu para aumentar o vínculo do sujeito comigo, o qual, mais à vontade, pareceu falar com menos constrangimentos, inclusive sobre aspectos que não pretendia abordar inicialmente.

Para não me perder em meio às digressões, controlei os tópicos que já haviam sido cobertos pelo sujeito ou não, numa folha com os objetivos da pesquisa (ANEXO B). 


\section{Capítulo 4}

\section{Análise dos dados}

Ninguém aprende a ler sozinho, e é importante observar como essa necessidade de mediação se manifesta na vida de cada pessoa [...].

As histórias canônicas de leitores e de leituras falam sempre das classes média e alta e, assim, ficamos com a idéia de que quem não nasceu entre os livros não tem jeito [...]. Isso porque não se conhecem (ou porque não se registram) histórias de outros segmentos sociais. 


\subsection{Apresentação dos dados: perfil dos sujeitos participantes da pesquisa}

Quando do início da análise de dados, optei por dividir os sujeitos da presente pesquisa em dois grupos, de acordo com o que lêem, para que lêem e o modo como lêem. Assim, sujeitos que afirmaram não gostar de ler, ter dificuldades para compreender a linguagem, não entender ou não se identificar com a temática das obras de literatura brasileira no rol daquelas estudadas na escola foram alocados num primeiro grupo, denominado grupo A de leitores. Já os sujeitos que afirmaram gostar de ler, não ter dificuldades para compreender a linguagem e a temática de obras clássicas da literatura brasileira foram reunidos num segundo grupo, chamado grupo B de leitores.

E por que não decidimos focar a análise de dados nos sujeitos apenas do grupo B? Porque no grupo $\boldsymbol{A}$ havia sujeitos lendo obras de filosofia, história e sociologia tão ou mais complexas que os clássicos da literatura; e, no grupo B de leitores, por outro lado, havia sujeitos que liam Machado de Assis e Drummond, mas não liam as sofisticadas obras de Ciências Humanas que os leitores do grupo $\boldsymbol{A}$ apreciavam. O campo revelou-se muito mais complexo e instigante do que havia inicialmente suposto. Pareceu-me valer a pena uma comparação entre os dois grupos.

No grupo A de leitores foram alocados 8 dos 13 pesquisados - AK47, André, Dandara, Frida, Laís, Maria, Marley e Paula -, os quais chamei de modo bastante abrangente apenas leitores. Já no grupo $\boldsymbol{B}$, foram reunidos os outros 5 sujeitos, os leitores de literatura $^{59}$ - Álvares, Beatriz, Malik, Taiko e Zapata ${ }^{60}$. Para facilitar a visualização, disponibilizei o quadro sinótico na página a seguir:

\footnotetext{
${ }^{59}$ De acordo com a acepção de literatura defendida por Soares (no prelo), a qual inclui as obras clássicas.

${ }^{60}$ Os nomes de todos os sujeitos e das pessoas citadas nos depoimentos foram trocados para preservar o anonimato dos sujeitos. Os pseudônimos de praticamente todos os sujeitos foram escolhidos por eles próprios. A exceção foi Laís, a primeira pessoa entrevistada, a quem não cheguei a solicitar o pseudônimo, e com a qual perdi contato posteriormente. Julguei útil esclarecer os motivos que os pesquisados alegaram para a seleção dos pseudônimos, pois estes estão revestidos de significação.
} 


\begin{tabular}{|c|c|c|c|}
\hline & \multicolumn{2}{|c|}{$\begin{array}{c}\text { Grupo } A \\
\text { Leitores }\end{array}$} & \multicolumn{2}{c|}{$\begin{array}{c}\text { Grupo B } \\
\text { Leitores de literatura }\end{array}$} \\
\hline 1 & AK47 & 1 & ÁLVARES \\
\hline 2 & ANDRÉ & 2 & BEATRIZ \\
\hline 3 & DANDARA & 3 & MALIK \\
\hline 4 & FRIDA & 4 & TAIKO \\
\hline 5 & LAÍS & 5 & ZAPATA \\
\hline 6 & MARIA & & \\
\hline 7 & MARLEY & & \\
\hline 8 & PAULA & & \\
\hline
\end{tabular}

Total: 13 pesquisados

Para expor os dados, em primeiro lugar, apresento os sujeitos, por grupo - A e B - e em ordem alfabética, fornecendo dados tais como idade, escolaridade, ocupação, com quem mora, posição entre os irmãos, escolaridade e ocupação dos pais, se é consulente, mediador de leitura da Biblioteca Comunitária Solano Trindade (BCST) e/ou membro do Força Ativa. Relato também as condições de coleta da entrevista, incluindo o tipo de relação que pareceu se estabelecer entre pesquisadora e sujeitos. A seguir, descrevo o perfil do sujeito como leitor, relacionando: as leituras anteriores à entrevista, o quê, onde, como e com que freqüência o sujeito costuma ler, o que ele afirma gostar de $\operatorname{ler}^{61}$ e o que deseja ler no futuro.

Em seguida, analiso a mediação de leitura exercida nos âmbitos da família, escola, biblioteca, grupo de pares e instituições religiosas. A apresentação desses dados foi organizada da seguinte forma: primeiro, dividimos o estudo por âmbitos e por grupos - A e B; ao final da análise de cada âmbito, comparo os dois grupos.

Posteriormente, abordo a constituição dos sujeitos de ambos os grupos à luz do referencial teórico adotado, detalhando a gênese de seu interesse por ler e quais foram as mediações de leitura mais significativas, exercidas pela família, escola, biblioteca, grupo de pares e instituições religiosas. Passo a fazer a seguir uma breve apresentação dos sujeitos entrevistados, por grupo em que foram reunidos e em ordem alfabética.

\footnotetext{
${ }^{61}$ Acredito que o que o sujeito gosta de ler não necessariamente corresponde ao que ele vem lendo, já que alguns pesquisados afirmaram estar bastante ocupados fazendo também leituras de caráter mais compulsório para atender a demandas escolares ou de trabalho.
} 


\subsection{Grupo A - os leitores: AK47, André, Dandara, Frida, Laís, Maria, Marley e Paula}

\section{AK47}

AK $47^{62}$ tem 24 anos e estava desempregado no momento da entrevista. Cursava o último ano de Ciências Sociais na Pontifícia Universidade Católica (PUC) de São Paulo, onde tinha uma bolsa. Sexto filho de um grupo de dez irmãos, morava quando da entrevista com cinco deles. Sua mãe, que não era alfabetizada, faleceu quando ele tinha 16 anos. Seu pai, com o qual AK47 não chegou a conviver, estudou até a quarta série do Ensino Fundamental e era mecânico.

Membro do Força Ativa, AK47 freqüentou a BCST desde sua criação e já atuou como atendente voluntário. Sua entrevista, com 70 minutos de duração, aconteceu na videoteca da BCST, uma pequena sala nos fundos da biblioteca, e sofreu apenas uma pequena interrupção. AK47 disse gostar de ler livros de filosofia e sociologia e também obras que abordem "temas centrais da humanidade”. Entre os últimos autores que havia lido, estavam Frei Beto e Ferréz. O sujeito disse que tem reservas quanto à literatura brasileira, que considera burguesa, e com cuja linguagem e temática não se identifica.

\section{ANDRÉ}

André ${ }^{63}$ tem 32 anos, completou o Ensino Médio e informou trabalhar em projetos sociais, mas não foi muito específico. Filho mais novo de um grupo de oito irmãos, morava com a mãe, a tia e uma irmã. Tem uma filha que não morava com ele. Seu pai, falecido em 1983, havia estudado até a quarta série do Ensino Fundamental e era zelador de uma igreja. Sua mãe, que não é alfabetizada, tinha atuado como trabalhadora doméstica e babá e, depois, passara a tomar conta de crianças em sua casa.

André não é membro do Força Ativa, mas conhece seus integrantes e ocasionalmente participa de um grupo de estudos na biblioteca. Sua entrevista, que durou duas horas, foi realizada na videoteca e sofreu uma pequena interrupção.

Ele declarou gostar de ler de tudo e interessar-se muito por livros que abordem questões religiosas. Porém, declarou não gostar de literatura brasileira, que considera uma

\footnotetext{
${ }^{62}$ AK47, nome de um fuzil, é uma referência indireta do entrevistado à idéia de revolução armada.

${ }^{63}$ André é o nome que a mãe do sujeito havia escolhido dar-lhe. No entanto, ao fazer o registro de nascimento, seu pai optou por outro nome, em homenagem ao frei da igreja católica com quem trabalhava.
} 
"leitura cansada" e de linguagem difícil. No momento da entrevista, tinha acabado de ler $A$ arte da guerra e almejava ver e ler o mais recente livro de fotos de Sebastião Salgado.

\section{DANDARA}

Dandara ${ }^{64}$ tem 26 anos, completou o Ensino Médio e estava desempregada no momento da entrevista. Preparava-se informalmente para prestar um concurso para agente escolar. Morava com sua irmã mais nova e com a mãe, que havia estudado até a $5^{\text {a }}$. série do Ensino Fundamental e atuara como trabalhadora doméstica. Depreendemos de seu depoimento que Dandara não conviveu com o pai.

Membro do Força Ativa, Dandara atua voluntariamente como atendente da BCST. Afirmou gostar de ler um pouco de tudo: gibis, romances, obras de História, Ciências Sociais e Africanidade. Disse escolher obras que chamem sua atenção e que lhe acrescentem alguma coisa. Também aprecia muito algumas obras de literatura infanto-juvenil que abordem temas com os quais se identifique, como as questões de classe e de raça.

Sua entrevista foi realizada nas instalações da BCST e sofreu uma pequena interrupção quando da chegada de um consulente.

\section{FRIDA}

Frida $^{65}, 24$ anos, cursava o último ano de Serviço Social na PUC de São Paulo, onde tinha uma bolsa. Fazia estágio como assistente social na subprefeitura de Cidade Tiradentes. Filha mais velha, morava com a mãe e dois irmãos menores. Seu pai, que trabalha na manutenção elétrica de um hospital, não chegou a completar o Ensino Fundamental. Sua mãe, desempregada no momento da entrevista, só recentemente concluiu o Ensino Médio.

Frida tornou-se membro do Força Ativa com cerca de 19 anos e atuou como atendente da biblioteca. No dia marcado para sua entrevista, a BCST estava fechada para reforma. Tivemos de coletar o relato de Frida do lado de fora, sentados com ela na grama. Não foram condições ideais, mas ainda assim seu relato foi bastante rico.

Frida disse gostar de ler obras que lhe acrescentem algo, sobre como a sociedade está organizada, sobre política, crianças e adolescentes, romances que tratem de fatos verídicos, e também gibis e histórias infantis. Não aprecia obras de literatura brasileira e não escolheria lêlas em seu tempo livre.

\footnotetext{
${ }^{64} \mathrm{O}$ pseudônimo Dandara foi escolhido em homenagem à companheira de Zumbi dos Palmares.

${ }^{65}$ A pesquisada optou pelo nome fictício Frida em homenagem à pintora mexicana Frida Kahlo.
} 


\section{LAÍS}

Laís $^{66}$, de 21 anos, tem Ensino Médio completo e, quando da entrevista, fazia um curso técnico de gestão hospitalar. No futuro, gostaria de fazer graduação em Psicologia. Filha mais nova, morava com a mãe, uma irmã e um irmão. Não conviveu com o pai. A mãe havia estudado até o $3^{\circ}$. ano e trabalhado muitos anos como cozinheira. Em seguida, passou a trabalhar como faxineira, devido à falta de escolaridade. Foi incentivada pelos filhos já adultos a voltar a estudar, o que estava fazendo quando o relato foi feito.

Laís não pertence ao Força Ativa, mas já havia atuado como atendente da BCST. A pesquisada disse gostar de ler de tudo e mostrou-se bastante entusiasmada com literatura juvenil e obras de Sociologia e História (com foco na história dos negros), além de livros que tratem de religiosidade. No momento da entrevista, estava lendo a bibliografia de seu curso técnico da área de saúde. Se tivesse mais tempo livre, gostaria de dedicar-se à leitura de livros de psicologia.

A entrevista de Laís, que durou cerca de 90 minutos, foi realizada nas instalações da BCST na presença de sua amiga Dandara e sofreu apenas uma breve interrupção.

\section{MARIA}

Maria $^{67}, 23$ anos, é servidora pública da prefeitura de Guarulhos, onde atua como educadora social junto a jovens de 16 a 18 anos incompletos. Filha caçula de sete irmãos, morava com eles e com a mãe, que não é alfabetizada. Seu pai, que não morava com a família desde que Maria tinha três anos e com quem esta havia perdido contato, estudou até a $4^{\mathrm{a}}$. série do ensino fundamental.

Quando seu relato foi coletado, Maria tinha passado para o segundo semestre de um curso de Biomédicas numa universidade privada, onde tinha uma bolsa do Programa Universidade para Todos (ProUni) ${ }^{68}$. Maria conheceu a BCST aos 16 anos e passou a integrar o Força Ativa aos dezoito.

\footnotetext{
${ }^{66}$ Conforme disse antes, não cheguei a solicitar a Laís que escolhesse um pseudônimo. Escolhi Laís por guardar semelhanças com seu nome original.

${ }^{67}$ Este pseudônimo foi escolhido pela pesquisada em homenagem a sua mãe.

${ }^{68} \mathrm{O}$ ProUni tem por finalidade a concessão de bolsas de estudo integrais e parciais em cursos de graduação e seqüenciais de formação específicas, em instituições privadas de educação superior. Criado pelo governo federal em 2004 e institucionalizado pela Lei no. 11.096 em janeiro de 2005, oferece isenção de alguns tributos às instituições de ensino que aderem ao programa. É dirigido aos estudantes egressos do ensino médio da rede pública ou da rede particular na condição de bolsistas integrais, com renda per capita familiar máxima de três salários mínimos. Os candidatos são selecionados pelas notas obtidas no Exame Nacional do Ensino Médio (ENEM). Fonte: http://portal.mec.gov.br/prouni/index.php, recuperado em 20.maio.2009
} 
O depoimento de Maria, que durou uma hora e cinco minutos, foi coletado em janeiro de 2008, na videoteca da BCST, e não sofreu interrupções.

Maria informou gostar de ler vários temas, já que o mundo para ela é "algo a ser desvendado em suas múltiplas facetas". Mas disse preferir autores que fazem uma avaliação crítica da sociedade e que apresentem alguma perspectiva de mudança. Ela tem especial interesse por questões raciais, políticas e de gênero. Gosta também de ler sobre Biologia.

No momento da entrevista, Maria estava lendo A formação econômica do Brasil, de Caio Prado Júnior. No futuro, desejava ler sobre a história do Brasil, e, mais especificamente, A sociologia do negro no Brasil, de Clóvis Moura. Queria também ler mais sobre a Revolução Russa - porque avaliou que não tinha tido um bom desempenho em alguns grupos de estudos do assunto na biblioteca -, além de Trabalho e Capital Monopolista, de Harry Braverman.

\section{MARLEY}

Marley $^{69}, 30$ anos, no momento da entrevista, trabalhava como educador social numa instituição do terceiro setor, atendendo crianças em situação de vulnerabilidade social. Havia iniciado um curso de graduação na Universidade da Cidadania Zumbi dos Palmares (UNIPALMARES) ${ }^{70}$. Morava com os pais, sua única irmã, que é 6 anos mais nova, e uma sobrinha de 5 anos. Tem um filho também de 5 anos, que não morava com ele, mas que o visitava regularmente. O pai de Marley havia estudado até a $4^{\text {a }}$. série do Ensino Fundamental e é metalúrgico aposentado. Sua mãe completou o Ensino Médio e é funcionária pública aposentada.

Membro do Força Ativa, Marley atua como voluntário na BCST. Ele disse gostar de ler de tudo, mas criticou bastante a linguagem difícil da literatura brasileira e disse apreciar bastante autores da chamada literatura marginal, como Ferréz. Gosta também Jack London, um romancista americano cujos protagonistas são negros. Quando da entrevista, pretendia ler obras de Aristóteles e Maquiavel.

Sua entrevista aconteceu nas instalações da BCST e foi interrompida quatro vezes. No entanto, tais quebras não prejudicaram a riqueza do relato, pois Marley estava muito disposto (e até ansioso) para falar de si e parece tê-lo feito sem grande auto-censura.

\footnotetext{
${ }^{69}$ Esse pseudônimo foi escolhido pelo sujeito e faz referência a Bob Marley.

${ }^{70}$ A UNIPALMARES - universidade privada fundada em 2003, em São Paulo - reserva 50\% de suas vagas para alunos negros. Conta com cerca de 1.900 alunos, distribuídos em dois cursos, Administração e Direito, dos quais $87 \%$ são afro-descendentes auto-declarados. Essa instituição cobra mensalidades de aproximadamente $50 \%$ do valor daquelas praticadas por outras universidades privadas.
} 


\section{PAULA}

Paula $^{71}, 20$ anos, é irmã gêmea de Beatriz, leitora que foi alocada no grupo B (leitores de literatura) e tem duas outras irmãs mais velhas. Estudara até o $2^{\circ}$. ano do Ensino Médio e estava à busca de trabalho quando da entrevista. Seu pai, que havia completado a $4^{\mathrm{a}}$. série do Ensino Fundamental, é funcionário público da prefeitura de Diadema, onde trabalha na portaria. Sua mãe, que faleceu subitamente quando as gêmeas tinham 15 anos, tinha retomado os estudos depois de casada, chegando a iniciar um curso de graduação. Era técnica em laboratório em um hospital. Paula e Beatriz conheceram a BCST há cerca de um ano.

Sua entrevista não sofreu nenhuma interrupção e foi realizada na sala de estar do apartamento em que ela e Beatriz moram com o pai e as duas irmãs mais velhas.

Paula disse gostar de ler romances (do tipo que classificaríamos como best sellers), autobiografias, literatura infanto-juvenil e obras de Paulo Coelho. À época da entrevista, desejava ler Crônicas de Nárnia.

\subsection{Grupo B - os leitores de literatura: Álvares, Beatriz, Malik, Taiko e Zapata}

\section{1. ÁLVARES}

Jovem de 28 anos, Álvares ${ }^{72}$ tem graduação em História por uma universidade privada e, quando seu depoimento foi coletado, atuava como professor de História na rede pública. Filho mais velho, Álvares morava com o irmão, a irmã e dois sobrinhos. Seu pai, falecido em 1999, era militar. Depois de ser precocemente aposentado por questões de saúde, tornou-se militante do Partido dos Trabalhadores. Sua mãe, também já falecida, era dona de casa. Havia parado de estudar para trabalhar quando jovem. Casou-se, teve filhos e só então concluiu o Ensino Fundamental.

Álvares conheceu a BCST há cerca de um ano. Também há relativamente pouco tempo, aproximou-se do Força Ativa. Leitor contumaz, de uma erudição impressionante, Álvares parece já ter lido inúmeras obras de Ciências Humanas, além de muitos clássicos da literatura brasileira, francesa, alemã e russa.

Sua entrevista, realizada na videoteca da BCST, não sofreu interrupções e durou duas

\footnotetext{
${ }^{71}$ A pesquisada escolheu seu pseudônimo em função da beleza que atribui ao nome.

${ }^{72} \mathrm{Na}$ ocasião da entrevista, este sujeito não quis escolher um pseudônimo. Posteriormente, aceitou a sugestão de adotar o nome Álvares, em referência a Álvares de Azevedo, já que, conforme o próprio sujeito tinha relatado, havia em sua família o temor de que, consumido por sua compulsão por leitura, ele morresse muito jovem, a exemplo do que havia acontecido com o escritor famoso.
} 
horas e 20 minutos.

\section{BEATRIZ}

Beatriz $^{73}$ tem 20 anos e é irmã gêmea de Paula, leitora alocada no grupo de leitores. Estudou até o $2^{\circ}$. ano do Ensino Médio e, assim como a irmã, estava à busca de trabalho quando da entrevista. Conforme dissemos antes, seu pai, que estudou até a $4^{\mathrm{a}}$. série do Ensino Fundamental, é funcionário público da prefeitura de Diadema, onde trabalha na portaria. E sua mãe, já falecida, era técnica em laboratório num hospital. Retomara os estudos depois de casada, chegando a ingressar num curso de graduação.

Beatriz e sua irmã conheceram a BCST há cerca de um ano.

Sua entrevista não sofreu nenhuma interrupção e foi realizada no apartamento em que ela e Paula moram com o pai e duas irmãs mais velhas.

Beatriz, assim como Paula, disse gostar de ler romances e autobiografias, literatura juvenil e obras de Paulo Coelho. Mas, diferentemente de Paula, Beatriz citou espontaneamente seu interesse por Drummond e Machado de Assis como escritores que apreciou ler em casa (e não para atender a uma demanda escolar) e contou-me sua saga em busca de uma obra do segundo autor.

\section{MALIK}

Malik $^{74}$ tinha 25 anos e, no momento da entrevista, acabara de graduar-se em Geografia numa universidade pública no interior de São Paulo. Começou a trabalhar como professor de Geografia na rede pública de escolas de São Paulo em 2008. Segundo filho de um grupo de quatro irmãos, Malik, no momento da entrevista, acabara de retornar para a casa dos pais, onde moraria com mais três irmãos e dois sobrinhos. Sua mãe, que só recentemente começou a alfabetizar-se, atuou como trabalhadora doméstica durante muitos anos e, por ocasião da coleta do depoimento, tomava conta de um bebê em sua própria casa. O pai de Malik estudou até a $4^{\mathrm{a}}$. série do Ensino Fundamental e alternou momentos de desemprego com ocupações informais, como, por exemplo, a venda de sorvetes em estádios de futebol.

Malik disse gostar de ler de tudo, e citou Lima Barreto e Paulo Freire como autores que tinha lido recentemente. Fez comentários depreciativos sobre a chamada literatura de

\footnotetext{
${ }^{73}$ A entrevistada escolheu esse pseudônimo devido à beleza que julga que o nome possui.

${ }^{74} \mathrm{O}$ sujeito escolheu o pseudônimo Malik, fazendo uma referência ao nome de origem de Malcolm X.
} 
massa e especificamente sobre obras de Dan Brown, livros de auto-ajuda e livros espíritas, como os de Zíbia Gasparetto. Informou também não ter compreendido, ao ler Machado de Assis pela primeira vez, ainda no Ensino Médio, o motivo pelo qual as pessoas diziam que as obras daquele escritor seriam de difícil compreensão.

Malik foi entrevistado na videoteca da BCST, sem interrupções, durante cerca de duas horas.

\section{TAIKO}

Taiko $^{75}$, de 17 anos, quando da entrevista, cursava o $3^{\circ}$. ano do Ensino Médio, e não estava à busca de trabalho. Filha mais velha, morava os pais e a irmã. O pai de Taiko fazia produtos de limpeza e só recentemente completara o Ensino Médio. Estava se preparando para iniciar um curso pré-vestibular na EDUCAFRO ${ }^{76}$. Quando se casou, a mãe de Taiko tinha estudado até a $4^{\text {a }}$. série e atuava como trabalhadora doméstica. Depois, completou o Ensino Fundamental e trabalhou como recepcionista de um supermercado. Estava de licença pelo INSS há três anos.

Taiko disse gostar de ler de tudo. Afirmou apreciar inclusive a leitura de obras clássicas de literatura brasileira e não reputá-las difíceis. No momento da entrevista, estava lendo Memórias Póstumas de Brás Cubas e gostando. Em seguida, desejava ler uma obra de suspense e horror, como $O$ Exorcista, por exemplo.

Como a BCST estava fechada para reforma em fevereiro, a entrevista de Taiko foi realizada na parte externa do bar ao lado da biblioteca. Por duas vezes, quando a entrevista parecia ter se encerrado, desliguei os aparelhos de gravação, e Taiko retomou o assunto da leitura. Voltei a ligá-los prontamente.

\footnotetext{
${ }^{75}$ Esse pseudônimo refere-se a um instrumento musical japonês, sobre o qual a pesquisada tinha lido recentemente num romance que se passava no Oriente.

${ }^{76}$ A Educação e Cidadania de Afro-descentes e Carentes (EDUCAFRO), rede de cursinhos pré-vestibulares comunitários, é um trabalho social do Serviço Franciscano de Solidariedade (SEFRAS), departamento da Província Franciscana da Imaculada Conceição do Brasil, uma associação da sociedade civil, sem fins lucrativos. Tem "a missão de promover a inclusão da população negra (em especial) e pobre (em geral), nas universidades públicas e particulares com bolsa de estudos, através do serviço de seus voluntários e voluntárias nos núcleos de pré-vestibular comunitários e setores da sua Sede Nacional, em forma de mutirão. No conjunto de suas atividades, a EDUCAFRO luta para que o Estado cumpra suas obrigações, através de políticas públicas e ações afirmativas na educação, voltadas para negros e pobres, promoção da diversidade étnica no mercado de trabalho, defesa dos direitos humanos, combate ao racismo e a todas as formas de discriminação" Fonte: http//:www.educafro.org.br, recuperado em 29.abril. 2009.
} 


\section{ZAPATA}

Zapata $^{77}$ tinha 31 anos e cursava o último ano de Letras na PUC, onde tinha uma bolsa. Sua ocupação mais recente fora a de educador social num Centro de Defesa da Criança e Adolescente (CEDECA). No momento da entrevista, tinha acabado de ficar desempregado. Seu pai estudou até a $4^{\text {a }}$. série do Ensino Fundamental e trabalhava como mecânico. Sua mãe, já falecida, não era alfabetizada. Quarto filho de um grupo de dez irmãos, Zapata tem uma filha 14 anos, que morava com ele e sua companheira.

Zapata é membro do Força Ativa desde a origem do grupo. Sua entrevista aconteceu nas instalações da BCST num dia de mutirão, na presença de mais dois colegas que haviam sido entrevistados em datas anteriores - Malik e Marley.

Zapata disse ler de tudo, não por gostar ou não de ler - questão que, para ele, não faz sentido -, mas "porque ler é uma necessidade humana tão básica quanto alimentar-se". Aprecia Lima Barreto, Guimarães Rosa e Manuel Bandeira, mas tem restrições a vários autores nacionais cuja ideologia classifica como "burguesa". Disse também não gostar da chamada "literatura marginal".

Disponibilizo a seguir dois quadros de dados sociobiográficos dos sujeitos dos grupos A (leitores) e B (leitores de literatura).

\footnotetext{
${ }^{77}$ Este pseudônimo foi escolhido pelo sujeito em alusão ao líder da Revolta Zapatista.
} 



\section{Dados socio-biográficos dos sujeitos - Grupo A (Leitores)}

\begin{tabular}{|c|c|c|c|c|c|c|}
\hline Sujeito & Sexo & Idade & Escolaridade & Ocupação & $\begin{array}{l}\text { Escolaridade }^{78} \\
\text { e ocupação da mãe }\end{array}$ & $\begin{array}{c}\text { Escolaridade } \\
\text { e ocupação do pai }\end{array}$ \\
\hline ANDRÉ & Masculino & 32 anos & $\begin{array}{l}\text { Ensino Médio } \\
\text { completo }\end{array}$ & $\begin{array}{l}\text { Trabalha em projetos } \\
\text { sociais }\end{array}$ & $\begin{array}{l}\text { Não alfabetizada } \\
\text { Babá }\end{array}$ & $\begin{array}{l}\text { Ensino Fundamental } \\
\text { incompleto } \\
\text { Zelador }\end{array}$ \\
\hline FRIDA & Feminino & 24 anos & $\begin{array}{l}\text { Cursando } \\
\text { Serviço Social }\end{array}$ & $\begin{array}{l}\text { Estagiária em } \\
\text { Serviço Social }\end{array}$ & Ensino Médio & $\begin{array}{l}\text { Ensino Fundamental } \\
\text { incompleto } \\
\text { Manutenção elétrica }\end{array}$ \\
\hline LAÍS & Feminino & 21 anos & $\begin{array}{l}\text { Ensino Médio } \\
\text { completo }\end{array}$ & Desempregada & $\begin{array}{l}\text { Ensino Fundamental } \\
\text { Incompleto }\end{array}$ & Não informada \\
\hline MARIA & Feminino & 23 anos & $\begin{array}{l}\text { Cursando } \\
\text { Biologia }\end{array}$ & Educadora social & Não alfabetizada & $\begin{array}{l}\text { Ensino Fundamental } \\
\text { incompleto } \\
\text { Ocupação não informada }\end{array}$ \\
\hline PAULA & Feminino & 20 anos & $\begin{array}{l}\text { Cursando o } \\
\text { Ensino Médio }\end{array}$ & Estudante & $\begin{array}{l}\text { Superior incompleto } \\
\text { Técnica de laboratório }\end{array}$ & $\begin{array}{l}\text { Ensino Fundamental } \\
\text { incompleto } \\
\text { Porteiro }\end{array}$ \\
\hline
\end{tabular}

\footnotetext{
${ }^{78}$ Praticamente todos os pais e mães que não completaram o Ensino Fundamental atingiram apenas a $4^{\mathrm{a}}$. série.
} 


\section{Dados socio-biográficos dos sujeitos - Grupo B (Leitores de literatura)}

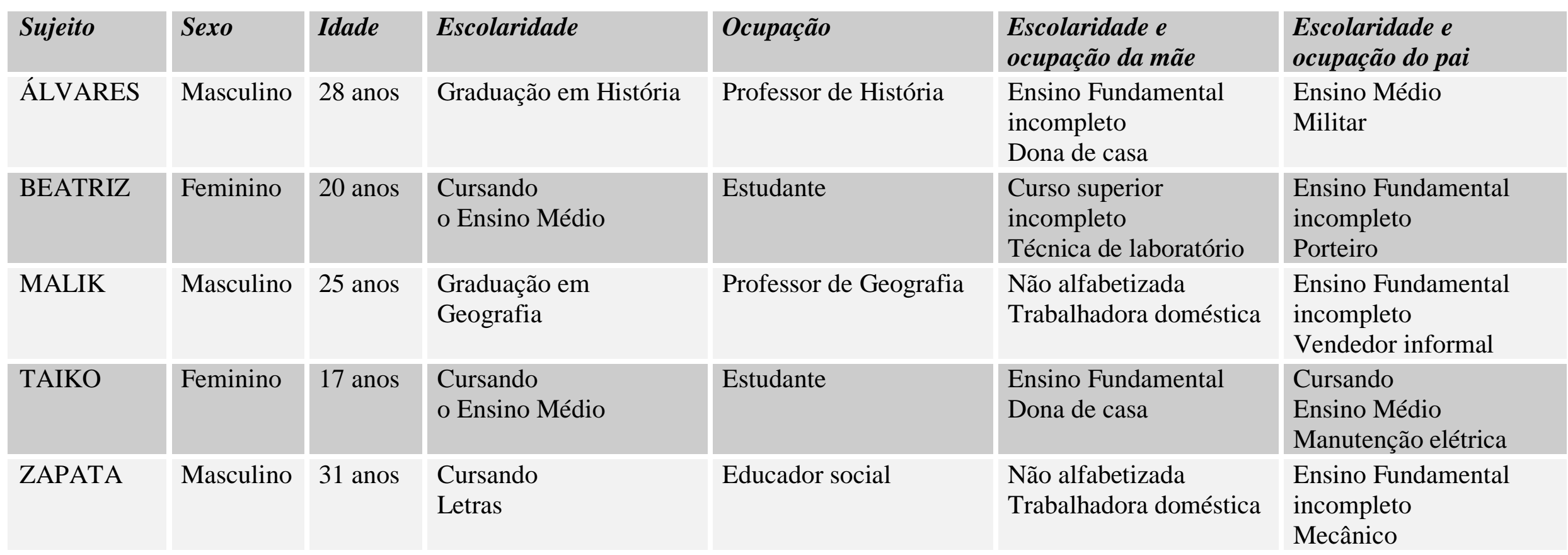


Chamou minha atenção que sujeitos com condições sócio-econômicas muito parecidas, todos alunos de escolas públicas de regiões periféricas da cidade de São Paulo, tivessem posições tão diferentes quanto ao que lêem e como lêem. Enquanto a maior parte dos sujeitos reputa a literatura brasileira como difícil e distante de sua realidade, 5 deles fizeram

afirmações no sentido oposto. À guisa de ilustração, citaremos apenas algumas delas: Álvares lê obras da literatura brasileira com extrema facilidade e as aprecia; Malik disse não ter compreendido, ao ler Memórias Póstumas de Brás Cubas ainda na adolescência, o porquê da reputação de difícil da obra; Taiko, da mesma forma que Malik, diz não encontrar dificuldades para a leitura de tais obras; Zapata aprecia obras clássicas em função de sua forma, dos jogos de palavras. Beatriz, irmã de Paula, parece uma leitora ainda em formação, mas decidimos incluí-la no grupo B de leitores devido à importância que atribuiu aos poucos meses de aulas de literatura com uma professora substituta, ao fato de ter empreendido uma verdadeira saga para conseguir ter acesso a um exemplar de Dom Casmurro, de Machado de Assis, e de ter lido e apreciado Amar, Verbo Intransitivo, de Carlos Drummond de Andrade. A despeito das semelhanças que poderia haver em seu histórico de vida com a da irmã gêmea, pareceu-me que sutis diferenças a separavam de Paula. Também sutis diferenças parecem separar os sujeitos do grupo $\mathrm{A}$ dos pesquisados do grupo $\mathrm{B}$. Elas não são nítidas à primeira vista, analisando-se, por exemplo, o quadro de dados sócio-biográficos acima. Porém, ao se fazer um estudo mais aprofundado das entrevistas dos sujeitos, elas emergem no âmbito da família, da escola, da biblioteca e do grupo de pares e ajudam a compreender como alguns sujeitos se constituíram leitores dispostos a fazer um leque maior de leituras, leque no qual estão inseridas obras clássicas da literatura brasileira.

\subsection{Freqüência e formas de acesso ao material impresso}

Um dos objetivos da análise de dados foi responder como e com que freqüência se deu o acesso a material impresso. Optei por dividir tal material em: gibis; revistas e jornais; livros didáticos e paradidáticos; literatura infantil e juvenil; e livros de modo geral. Ao utilizar o termo livros, refiro-me a todo e qualquer livro que não seja livro didático dos Ensinos Fundamental e Médio, livros paradidáticos, livros de literatura infanto-juvenil ou a Bíblia. Assim, o termo livros refere-se a obras de cunho, por assim dizer, mais adulto. Incluímos nessa categoria obras de literatura, história, filosofia, sociologia, best-sellers, auto-ajuda, esotéricas etc. O primeiro motivo disso é que vários dos leitores entrevistados não 
conseguiram categorizar as obras a que tiveram acesso (ficção, não-ficção, auto-ajuda etc). Outro motivo é que o acesso ao material impresso pode ter sido tão raro que não faria sentido analisá-lo dividindo diferentes tipos de livros. Por outro lado, pareceu relevante realçar as obras de literatura infanto-juvenil, dada a importância que vários leitores atribuíram a elas para sua constituição, em especial a Coleção Vaga-lume.

Procurei ainda fazer a análise levando em conta a idade que os sujeitos teriam, caso não houvesse defasagem ano/série, no $1^{\circ}$. segmento do Ensino Fundamental (até 10 anos), no $2^{\circ}$. segmento desse mesmo nível de ensino (de 11 a 13 anos); no Ensino Médio (de 14 a 17 anos); de 18 a 30 anos.

Ao falarem de acesso a material impresso, os sujeitos citaram os seguintes âmbitos: família (o que compreende não apenas os moradores do lar do sujeito, mas também avós, tios, primos etc); escola (Ensino Fundamental e Médio); cursos diversos feitos ao final da escolarização básica, dentre os quais tiveram especial relevância os cursos pré-vestibulares comunitários (como a EDUCAFRO e o MSU), os quais decidi reunir na categoria outras modalidades de escolarização (OME); no local de trabalho; na biblioteca escolar (BE), biblioteca pública (BP), biblioteca comunitária (BC) e biblioteca da universidade (BU); o grupo de pares (GP) na escola, no trabalho, no grupo de estilo, na militância etc. Assim, ao se ler "Trabalho" deve-se compreender que o material estava disponível no local de trabalho, como aconteceu com Malik; já ao se ler "GP no trabalho", deve-se compreender que o material circulava por meio de empréstimos entre os colegas de trabalho.

Para uma melhor visualização dos dados coletados, disponibilizo a seguir um quadro sinóptico das memórias de acesso dos sujeitos do grupo A (Leitores) e do grupo B (Leitores de literatura), as quais, de acordo com as entrevistas, foram, na maior parte dos casos, memórias de restrição de acesso. 


\section{ACESSO A MATERIAL IMPRESSO - GRUPO A (leitores)}

\begin{tabular}{|c|c|c|c|c|c|c|c|c|}
\hline Sujeito & Idade & Gibis & Revistas & Jornais & $\begin{array}{l}\text { Livros didáticos, } \\
\text { Paradidáticos }\end{array}$ & $\begin{array}{l}\text { Livros de } \\
\text { literatura infantil } \\
\text { e juvenil }\end{array}$ & Livros & Outros \\
\hline \multirow[t]{4}{*}{ AK47 } & Até 10 & Família & & & Escola & & & \\
\hline & $11-13$ & & & & $\begin{array}{l}\text { Não acesso: } \\
\text { reprovação }\end{array}$ & BE (6 ${ }^{\mathrm{a}}$. série apenas) & & \\
\hline & $14-17$ & & $\begin{array}{l}\text { Família (rev. } \\
\text { religiosas) }\end{array}$ & $\begin{array}{l}\text { Gratuitos, } \\
\text { religiosos }\end{array}$ & & & Família & Bíblia-Família \\
\hline & $18-24$ & & & $\begin{array}{l}\text { Família } \\
\text { BU }\end{array}$ & & & $\begin{array}{l}\text { Família GP (Força } \\
\text { Ativa) BC Sebo BU }\end{array}$ & Textos OME \\
\hline \multirow[t]{4}{*}{ ANDRÉ } & Até 10 & & & & & & & \\
\hline & $11-13$ & & & & & $\begin{array}{l}\text { Escola (emprést. Profa } \\
\text { LP) Vizinhos Família }\end{array}$ & & \\
\hline & $14-17$ & $\begin{array}{l}\text { Aquisição pelo } \\
\text { leitor. Ocasional }\end{array}$ & $\begin{array}{l}\text { Sebo (bancas) } \\
\text { GP }\end{array}$ & & $\begin{array}{l}\text { BP (Trab. escolares, } \\
\text { sem empréstimos) }\end{array}$ & & $\begin{array}{l}\text { GP escola e trabalho } \\
\text { BP e Sebo }\end{array}$ & $\begin{array}{l}\text { Apostilas - GP } \\
\text { trabalho }\end{array}$ \\
\hline & $18-30$ & & & & & & GP militância e BC & \\
\hline \multirow[t]{4}{*}{ DANDARA } & Até 10 & $\begin{array}{l}\text { Aquisição pelo } \\
\text { leitor. Ocasional. }\end{array}$ & & & $\mathrm{BE}$ (muito raramente) & & $\begin{array}{l}\text { Família (doação } \\
\text { ocasional) }\end{array}$ & \\
\hline & $11-13$ & & & & & & $\begin{array}{l}\text { Família (doação } \\
\text { ocasional) }\end{array}$ & \\
\hline & $14-17$ & & & & & & $\begin{array}{l}\text { Família (doação } \\
\text { ocasional) }\end{array}$ & \\
\hline & $18-30$ & & & & & & BC (22 anos) & \\
\hline \multirow[t]{4}{*}{ FRIDA } & Até 10 & Família & & Família & Família & BE (pré e 1o. ano) & & \\
\hline & $11-13$ & GP & $\begin{array}{l}\text { Aquisição pelo } \\
\text { leitor }\end{array}$ & & $\begin{array}{l}\text { BP } \\
\text { GP }\end{array}$ & & & \\
\hline & $14-17$ & & $\begin{array}{l}\text { Aquisição pelo } \\
\text { leitor }\end{array}$ & & & & & \\
\hline & $18-30$ & & & & & & BC, GP, sebo & \\
\hline
\end{tabular}




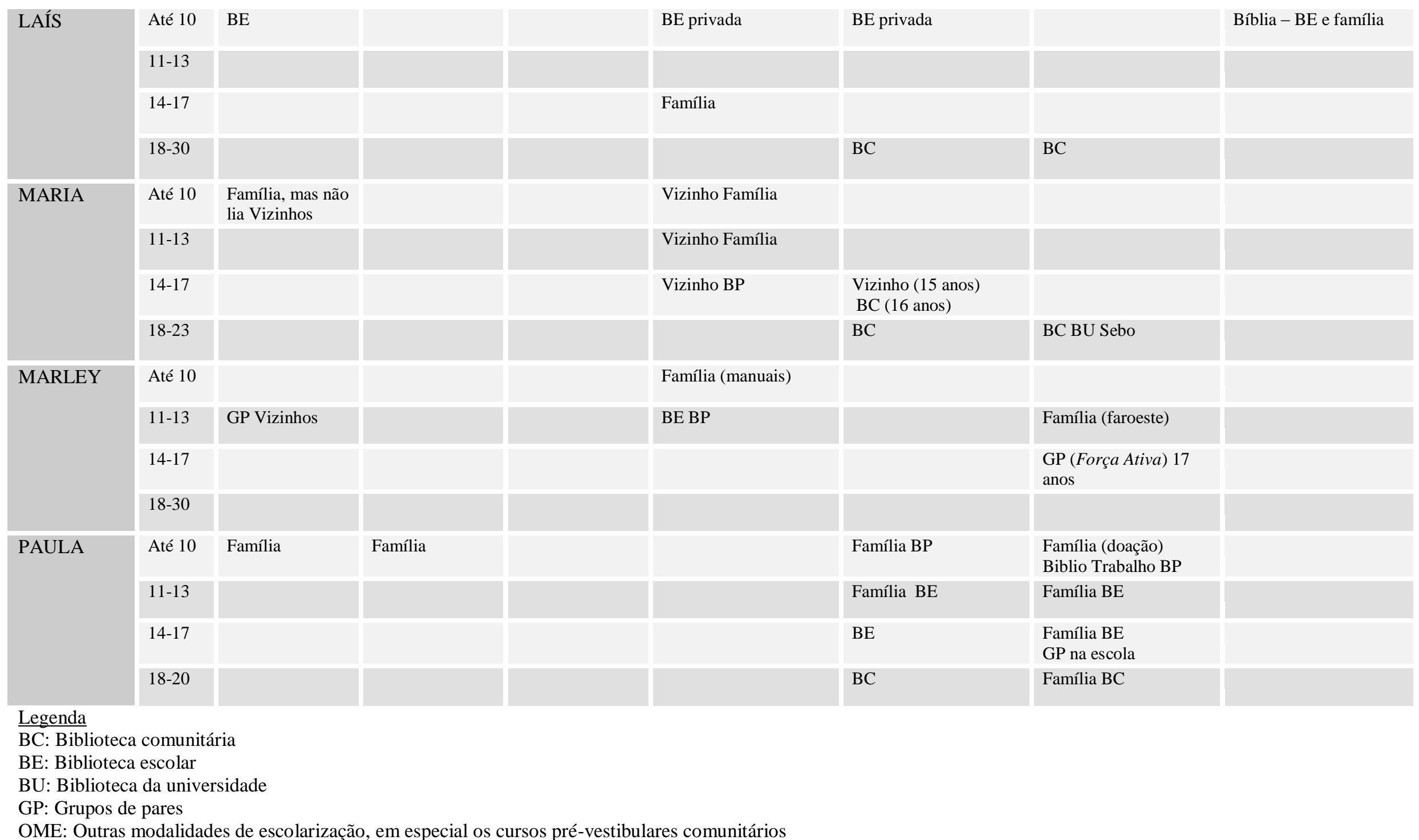




\section{ACESSO A MATERIAL IMPRESSO - GRUPO B (leitores de literatura)}

\begin{tabular}{|c|c|c|c|c|c|c|c|c|}
\hline Sujeito & $\begin{array}{l}\text { Idade } \\
\text { (anos) }\end{array}$ & Gibis & Revistas & Jornais & $\begin{array}{l}\text { Livros didáticos, } \\
\text { Paradidáticos }\end{array}$ & $\begin{array}{l}\text { Livros de literatura } \\
\text { infantil e juvenil }\end{array}$ & Livros & Outros \\
\hline \multirow[t]{4}{*}{ ÁLVARES } & Até 10 & $\begin{array}{l}\text { BP } \\
\text { GP na escola }\end{array}$ & Família & & $\begin{array}{l}\text { Família } \\
\text { BE }\end{array}$ & $\begin{array}{l}\text { Família } \\
\text { BP }\end{array}$ & $\begin{array}{l}\text { Família } \\
\text { BP }\end{array}$ & \\
\hline & $11-13$ & $\mathrm{BP}$ & Família & & Família & $\begin{array}{l}\text { Família } \\
\text { BP }\end{array}$ & $\begin{array}{l}\text { Família } \\
\text { BP }\end{array}$ & \\
\hline & $14-17$ & $\mathrm{BP}$ & Família & & Família & $\begin{array}{l}\text { Família } \\
\text { BP }\end{array}$ & $\begin{array}{l}\text { Família } \\
\text { BP }\end{array}$ & \\
\hline & $18-30$ & & Família & & & & $\begin{array}{l}\text { Família, GP, BP, BU, } \\
\text { Trabalho }\end{array}$ & \\
\hline \multirow[t]{4}{*}{ BEATRIZ } & Até 10 & Família & Família & & Família Escola & $\begin{array}{l}\text { Família } \\
\text { BP }\end{array}$ & $\begin{array}{l}\text { Família (doação) } \\
\text { Biblio Trabalho BP }\end{array}$ & \\
\hline & $11-13$ & Família & & & Família Escola & $\begin{array}{l}\text { Família } \\
\text { BE }\end{array}$ & $\begin{array}{l}\text { Família BE } \\
\text { Biblio Trabalho }\end{array}$ & \\
\hline & $14-17$ & & Trabalho pai & & $\begin{array}{l}\text { Família } \\
\text { Escola }\end{array}$ & $\mathrm{BE}$ & $\begin{array}{l}\text { Família BE } \\
\text { GP na escola Namorado }\end{array}$ & \\
\hline & $18-30$ & & & & $\begin{array}{l}\text { Família } \\
\text { Escola }\end{array}$ & $\mathrm{BC}$ & $\begin{array}{l}\text { Família Namorado } \\
\text { BC }\end{array}$ & \\
\hline \multirow[t]{4}{*}{ MALIK } & Até 10 & $\begin{array}{l}\text { Família (doação) } \\
\text { GP na escola } \\
\text { (empréstimo) }\end{array}$ & Família (doação) & & $\begin{array}{l}\text { Escola (doação da } \\
\text { profa.) } \\
\text { Leitura antecipada de } \\
\text { textos em LD }\end{array}$ & $\begin{array}{l}\text { BE (sem mediação e sem } \\
\text { circulação) }\end{array}$ & & \\
\hline & $11-13$ & $\begin{array}{l}\text { Aquisição pelo } \\
\text { leitor (usados) }\end{array}$ & Família (doação) & & $\begin{array}{l}\text { Falta de LD } \\
\text { (Cópia da lousa) }\end{array}$ & $\begin{array}{l}\text { BE até } 5 \text {. série } \\
\text { Não acesso a livro de LIJ } \\
\text { pedido em LP. }\end{array}$ & & \\
\hline & $14-17$ & & $\begin{array}{l}\text { Família (doação) } \\
\text { Trabalho }\end{array}$ & & $\begin{array}{l}\text { Escola } \\
\text { Textos geografia em } \\
\text { livros didáticos }\end{array}$ & & $\begin{array}{l}\text { BE fechada - } 1 \text { livro } \\
\text { apenas. }\end{array}$ & $\begin{array}{l}\text { Texto / Música } \\
\text { GP na escola }\end{array}$ \\
\hline & $18-30$ & & $\begin{array}{l}\text { Sebo } \\
\text { GP do rock e rap } \\
\text { OME }\end{array}$ & & $\begin{array}{l}\text { OME (Empréstimo de } \\
\text { profs. Educafro) }\end{array}$ & & $\begin{array}{l}\text { OME (Empréstimo de } \\
\text { profs. Educafro) } \\
\text { Aquisição pelo leitor, } \\
\text { Sebo, GP, OME, BU }\end{array}$ & $\begin{array}{l}\text { Textos - OME Emprést. } \\
\text { de profs. } \\
\text { GP rap }\end{array}$ \\
\hline
\end{tabular}




\begin{tabular}{|c|c|c|c|c|c|c|c|}
\hline \multirow[t]{3}{*}{ TAIKO } & Até 10 & Família (usados) & & Família (doação) & Família (aquisição) & & Bíblia - \\
\hline & $11-13$ & & & Escola & $\begin{array}{l}\mathrm{BE} \\
\mathrm{BC}\end{array}$ & $\begin{array}{l}\mathrm{BE} \\
\mathrm{BC}\end{array}$ & $\begin{array}{l}\text { Bíblia } \\
\text { Livretos de OME } \\
\text { Panfletos de palestras }\end{array}$ \\
\hline & $\begin{array}{l}14-17 \\
\text { anos }\end{array}$ & & & Escola & $\begin{array}{l}\mathrm{BE} \\
\mathrm{BC}\end{array}$ & $\begin{array}{l}\mathrm{BE} \\
\mathrm{BC}\end{array}$ & $\begin{array}{l}\text { Bíblia } \\
\text { Livretos de OME } \\
\text { Panfletos de palestras }\end{array}$ \\
\hline \multirow[t]{4}{*}{ ZAPATA } & Até 10 & Família & $\begin{array}{l}\text { Família } \\
\text { (religião) }\end{array}$ & $\begin{array}{l}\text { Escola (doação LD } \\
\text { professora) BP }\end{array}$ & & $\begin{array}{l}\text { Família } \\
\text { BP }\end{array}$ & \\
\hline & $11-13$ & & & BP & & & \\
\hline & $14-17$ & & & & & GP & \\
\hline & $18-30$ & & & & & $\begin{array}{l}\text { BU } \\
\text { GP (rap e militância) }\end{array}$ & \\
\hline
\end{tabular}

\section{BC: Biblioteca comunitária}

BE: Biblioteca escolar

BU: Biblioteca da universidade

GP: Grupos de pares

OME: Outras modalidades de escolarização, em especial os cursos pré-vestibulares comunitários 


\subsubsection{O acesso a material impresso pelo Grupo A (os leitores)}

Depreende-se dos depoimentos que, de modo geral, os sujeitos do grupo A tiveram acesso muito restrito a material impresso durante longos períodos de sua infância e adolescência. Sete dos 8 sujeitos - AK47, André, Dandara, Frida, Laís, Maria e Marley dependeram quase exclusivamente de empréstimos ou doações esporádicas de material de segunda mão, já que o acesso não foi garantido nem pela escola nem pelas bibliotecas pública ou escolar nem pela família.

Outro fato que chama a atenção no grupo A é que o acesso a material impresso se deu mais tardiamente. AK47 teve acesso a gibis e à cartilha até os 10 anos. Não leu nada para além dos livros didáticos e paradidáticos para atender a demandas escolares. Só aos 16 anos leu seu primeiro livro, curioso com o fato de seus irmãos mais velhos acumularem livros de filosofia, sociologia, história em casa. André relatou ter tido muito pouco contato com material impresso até os 11 anos. A partir de então, o acesso dependeu de empréstimos de vizinhos e amigos na escola. A partir dos 14 anos, leu revistas emprestadas e comprou gibis e livros em sebos. Mas dos 17 em diante, o acesso novamente se tornou restrito, pois o sujeito ficou desempregado e terminou o Ensino Médio, o que reduziu sua possibilidade de aquisição ou de empréstimos no trabalho e na escola. Dandara declarou só ter começado a ler já adulta, com cerca de 23 anos, quando conheceu a BCST. Na infância manuseou apenas alguns gibis doados a sua mãe. Frida e Laís tiveram acesso a material impresso nos primeiros anos do Ensino Fundamental. Ambas só passaram a ter acesso a farto material impresso por volta dos 16 ou 17 anos, quando conheceram a BCST. Até então, Laís havia lido majoritariamente a Bíblia e Frida, revistas de rap. Maria, que tinha alguns gibis em casa mas não os lia, só aos 15 anos começa a ler algo para além das leituras demandadas pela escola para o cumprimento de alguma tarefa, graças ao material impresso disponibilizado por seus vizinhos. O contato de Marley com gibis se dá somente a partir dos 12 anos. E o acesso a material impresso para além dos livros didáticos ou paradidáticos ou dos manuais técnicos dos pais só aconteceu a partir dos 17 anos, por intermédio dos pares na militância (parte dos quais veio a integrar o Força Ativa). Nesse grupo, apenas Paula teve acesso ininterrupto a material impresso desde a infância até o momento da entrevista. E também apenas Paula teve o acesso a tal material garantido por sua família e pelas bibliotecas pública e escolar.

Dos 8 sujeitos do grupo A de leitores, em apenas 4 casos - AK47, Dandara, Frida e Paula - houve gibis no ambiente doméstico. Para 2 sujeitos - Maria e Marley -, o acesso se 
deu por meio de vizinhos. E para Laís, por meio do internato em que estudava. O sujeito André não teve acesso a gibis até os 14 anos.

Cinco dos 8 sujeitos do grupo A não tiveram acesso a revistas e jornais até pelo menos o encerramento da escolarização básica. As exceções foram 3 sujeitos: Paula, que leu ocasionalmente revistas que circulavam na família e jornais no local de trabalho do pai; Frida, que comprou revistas de rap durante a adolescência; e AK47, que leu jornais e revistas de cunho religioso distribuídas gratuitamente no bairro e, apenas após os 18 anos, teve acesso temporário a um jornal de circulação nacional.

Para vários dos 8 sujeitos do grupo A, estar na escola não foi sinônimo de acesso a livros didáticos. Dois desses 8 sujeitos - AK47 e Dandara - relataram não ter usado livros didáticos em algum período de sua escolarização ${ }^{79}$. Embora os outros 6 sujeitos não tenham sido tão explícitos, depreende-se de seus depoimentos a restrição de acesso a esses materiais. Sabe-se que programas governamentais que visam a garantir aos alunos das escolas públicas o acesso a livros didáticos vieram historicamente ampliando sua abrangência ${ }^{80}$. Isso faria supor

\footnotetext{
${ }^{79}$ No caso de AK47, a falta do livro didático de uma disciplina quando da mudança da família para Cidade Tiradentes, na sexta série, acarretou crescente absenteísmo do aluno e, em seguida, sua reprovação.
}

${ }^{80}$ O Programa Nacional do Livro Didático (PNLD) é o mais antigo dos programas voltados à distribuição de obras didáticas aos estudantes da rede pública de ensino fundamental e iniciou-se, com outra denominação, em 1929. Desde então, o programa foi se aperfeiçoando e teve diferentes nomes e formas de execução, mas nem sempre garantiu o acesso universal aos livros didáticos. Em 1976, por exemplo, devido à alegada "insuficiência de recursos para atender todos os alunos do ensino fundamental da rede pública, a grande maioria das escolas municipais [foi] excluída do programa". Segundo informações do próprio governo federal, em 1992, a distribuição dos livros foi comprometida pelas limitações orçamentárias e houve um recuo na abrangência da distribuição, restringindo-se o atendimento até a $4^{\text {a }}$ série do ensino fundamental. Apenas em 1993 é que se vinculou parte do orçamento federal à aquisição dos livros didáticos, estabelecendo-se, assim, um fluxo regular de verbas para a aquisição e distribuição de tal material. Muito gradativamente, voltou a universalização da distribuição do livro didático no ensino fundamental. Ainda assim, em 1995, foram contempladas apenas as disciplinas de matemática e língua portuguesa. Em 1996, a de ciências e, em 1997, as de geografia e história. Ainda em 1997, a responsabilidade pela política de execução do PNLD foi transferida integralmente para o Fundo Nacional de Desenvolvimento da Educação (FNDE). O programa foi ampliado e o Ministério da Educação passou a adquirir, de forma continuada, livros didáticos de alfabetização, língua portuguesa, matemática, ciências, estudos sociais, história e geografia para todos os alunos de $1^{\mathrm{a}}$ a $8^{\mathrm{a}}$ série do ensino fundamental público. Apenas em 2000 é que foi inserida no PNLD a distribuição de dicionários da língua portuguesa e, ainda assim, apenas para uso dos alunos de $1^{\mathrm{a}}$ a $4^{\mathrm{a}}$ séries.

O ensino médio não foi contemplado por programas governamentais até 2004, quando se implantou o Programa Nacional do Livro para o Ensino Médio (PNLEM). Inicialmente, o PNLEM atendeu apenas 1,3 milhão de alunos da $1^{\text {a }}$ série do ensino médio de escolas das regiões Norte e Nordeste, que receberam livros somente das disciplinas de português e de matemática. Em 2005, as demais séries e regiões brasileiras também foram atendidas, mas novamente apenas com livros de português e matemática. Apenas em 2007 foi feita a escolha dos livros didáticos de história e de química, que seriam usados em 2008. Somente para 2009 é que estava prevista a inclusão das disciplinas de geografia e física. Fonte: http://www.fnde.gov.br/home/index.jsp?arquivo= livro_didatico.html\#pnld, recuperado em 20.abril.2009. 
que os relatos sobre falta de livros didáticos fossem feitos por sujeitos mais velhos, que não teriam, em tese, sido beneficiados por tais programas. No entanto, AK47 e Dandara contavam, na época da entrevista (2008) com 24 e 27 anos, respectivamente, o que leva a crer que ironicamente os bairros novos como Cidade Tiradentes, justamente aqueles em que os alunos eram de famílias de menor renda, foram provavelmente os que demoraram mais a ser abrangidos por programas. Tal fato é ainda mais grave se considerarmos que, de acordo com os depoimentos dos sujeitos, as bibliotecas escolares faziam parte do equipamento escolar em bairros menos afastados e mais antigos (como Jabaquara ou Jaçanã), mas simplesmente inexistiam em Cidade Tiradentes.

Para 4 dos 8 sujeitos desse grupo - André, Frida, Maria e Marley -, o acesso a livros didáticos e paradidáticos deu-se na biblioteca pública, na qual fizeram cópias para "tirar matéria". No entanto, tais sujeitos não faziam empréstimos devido às exigências burocráticas ou à distância entre a biblioteca e suas casas, a qual demandava o uso de transporte público, cuja tarifa inviabilizava a devolução.

A quase totalidade das escolas freqüentadas pelos sujeitos não dispunha de biblioteca escolar. Quando ela existia, era fechada ou utilizada apenas para realização de trabalhos escolares durante o período de aulas e na presença do professor justamente para remediar a falta de material didático. Dos 8 sujeitos, apenas 4 - AK47, Frida, Maria e Marley recordaram-se de ter ido à biblioteca escolar e, ainda assim, durante um período muito breve: 1 ou 2 anos. Somente uma entrevistada - Paula - freqüentou a biblioteca escolar por longo tempo - da sexta série ao primeiro ano do Ensino Médio. Sua história é muito dissonante das dos outros sujeitos, já que seu acesso à biblioteca foi contínuo - até mesmo nas férias - e já que o acervo dessa biblioteca era circulante.

Apenas em 2 casos a - Frida e Maria -, a família pôde adquirir livros didáticos ou paradidáticos. Para essa última leitora, o uso de tais livros foi garantido também pelos vizinhos.

De modo geral, os depoimentos dos sujeitos do grupo A de leitores apontaram a extrema restrição de acesso a obras de literatura infantil e juvenil. A escola e a biblioteca escolar não figuraram como fornecedoras de tais obras em momento algum na trajetória de 4 dos 8 sujeitos - André, Dandara, Maria e Marley. Três outros leitores - AK47, Frida e Laís tiveram acesso a tais materiais por meio da escola ou da biblioteca escolar muito raramente e apenas durante um período curtíssimo. Apenas uma leitora - Paula - leu de modo regular, 
irrestrito e prolongado literatura infanto-juvenil por meio da biblioteca de sua escola, localizada numa cidade da região metropolitana de São Paulo. E apenas uma leitora novamente Paula - leu literatura infantil fornecida por biblioteca pública. Dos 8 componentes do grupo A de leitores, 4 - AK47, Frida, Laís e Marley - relataram não ter lido obras de literatura juvenil em momento algum de sua escolarização.

Nesse contexto de ausência do Estado, 2 leitores - André e Maria - tiveram acesso a literatura juvenil por meio de vizinhos. André contou ainda com amigos na escola ou com os empréstimos da própria professora de Língua Portuguesa. Para 3 leitores - Dandara, Laís e Maria -, a partir de cerca de 17 anos, a BCST tornou-se a principal provedora de obras de literatura juvenil.

Apenas 3 dos 8 leitores - André, Dandara e Paula - relataram ter lido alguma obra de literatura infanto-juvenil por meio de suas famílias. No entanto, somente no caso de Paula tal acesso foi regular. Para André e Dandara, ele foi extremamente raro e se deu por meio de um irmão mais velho de André ou de doações das patroas da mãe de Dandara.

Dos 8 sujeitos do grupo A, apenas 4 - AK47, Dandara, Marley e Paula - relataram que havia livros em suas casas para além dos didáticos ou paradidáticos. Em 2 casos, eles chegaram lá por meio de doações ocasionais feitas a suas mães no local de trabalho. Em outros dois, eles circulavam na própria família.

Os amigos na escola, no trabalho ou o grupo de estilo (rap) foram mencionados por 4 sujeitos - AK47, André, Paula e Marley - como importante fonte de livros até aproximadamente o encerramento do ensino médio. Para um dos sujeitos - André -, a inserção no mercado de trabalho favoreceu o acesso a livros na região central da cidade, por meio de sebos, pelos colegas no trabalho e, mais raramente, visitas à biblioteca pública. É importante ressaltar, porém, que o sujeito sentia-se pouco à vontade na biblioteca pública e julgava que o sebo era um ambiente muito mais democrático, menos intimidador. Além de André, mais 2 leitores - AK47 e Frida - mencionaram os sebos como o meio de acesso a livros. Dois leitores - AK47 e Maria - aludiram também à biblioteca da universidade.

Em síntese, para a vasta maioria dos leitores do grupo A, o acesso a material impresso foi restrito, muito descontínuo, deu-se mais tardiamente e não foi garantido nem pela família nem pela escola ou pelas bibliotecas escolar ou pública. A maior parte dos sujeitos não leu revistas, jornais, livros e os materiais impressos tipicamente destinados à infância e à adolescência: gibis, literatura infantil e literatura juvenil. Além disso, também não fizeram uso contínuo de livros didáticos, ou porque não puderam adquiri-los ou porque eles não foram adotados e distribuídos por suas escolas. 


\subsubsection{O acesso a material impresso pelo Grupo B (os leitores de literatura)}

De modo geral, conforme a própria tabela apresentada nas páginas 130 e 131 evidencia, o acesso a material impresso parece ter sido menos restrito e, no caso de 2 dos 5 sujeitos - Álvares e Beatriz - até bastante farto. O acesso de todos os leitores parece ter sido favorecido mais precocemente, ter tido um caráter mais contínuo e ter se dado num número maior de âmbitos. Dentre os âmbitos em que se deu o acesso, no grupo B, a família de 4 sujeitos - Álvares, Beatriz, Taiko e Zapata - teve grande relevância, adquirindo material, tomando-o emprestado ou dele recebendo doações. Quando o material não esteve disponível no âmbito familiar, os sujeitos o conseguiram via biblioteca pública ou escolar ou no grupo de pares.

No grupo B, apenas 1 sujeito - Malik - relatou ter enfrentado forte descontinuidade de acesso a material, o que se deu entre a $6^{\mathrm{a}}$. e a $8^{\mathrm{a}}$. séries do Ensino Fundamental, período em que, ainda assim, crê ter lido três livros. No entanto, a partir dos 12 anos, o sujeito já adquiria com recursos próprios gibis usados, cuja ambientação e linguagem sofisticadas o instigavam a aprender.

No grupo $\mathrm{B}$, todos os 5 sujeitos estiveram envolvidos em práticas de leitura bem precocemente, antes mesmo da alfabetização e/ou já nos primeiros anos do ensino fundamental. Além disso, parece não ter havido um tempo de real afastamento da leitura.

Todos os 5 componentes do grupo $\mathrm{B}$ de leitores tiveram acesso a gibis desde os primeiros anos da infância, o primeiro dos quais se deu majoritariamente no lar do sujeito. Em ao menos 3 casos - Malik, Taiko e Zapata - os gibis no lar provavelmente não foram adquiridos pela família: foram doados por parentes ou patrões da mãe trabalhadora doméstica. Apenas as famílias de Beatriz e Álvares parecem ter comprado gibis novos. Dois sujeitos Álvares e Malik - leram gibis de amigos na escola. Esse segundo sujeito passou a comprar gibis usados do Konan a partir dos 12 anos, com recursos de trabalhos informais. Apenas um sujeito - Álvares - leu gibis por meio da biblioteca pública, dentre os quais Asterix.

Três dos 5 sujeitos - Beatriz, Malik e Zapata - tiveram acesso a revistas e jornais, ainda que apenas esporadicamente, antes dos 14 anos. Malik leu algumas poucas revistas usadas e revistas semanais de circulação nacional no local de trabalho, a partir dos 14 anos. Depois, passou a adquirir revistas em sebos ou a tomá-las emprestadas com seus pares nos grupos de estilo (rock e rap). Beatriz leu revistas por meio de sua família e jornais ocasionalmente no trabalho do pai. No âmbito doméstico, no caso de Zapata, circulavam revistas gratuitas de cunho religioso. A entrevistada Taiko não parece ter lido revistas ou 
jornais, mas leu publicações de instituições como a EDUCAFRO. Apenas 1 sujeito - Álvares - teve acesso farto e contínuo a jornais e revistas, que circulavam no ambiente doméstico.

Três sujeitos - Álvares, Beatriz e Taiko - parecem ter utilizado e lido livros didáticos e paradidáticos continuamente: Álvares e Beatriz na família, na escola e na biblioteca escolar; e Taiko na escola e na família, por meio de doações de usados. Já outros 2 sujeitos Malik e Zapata - explicitaram a extrema falta de livros didáticos no Ensino Fundamental e relataram a eventual doação deles (e de algum outro material escolar) por suas respectivas professoras nos primeiros anos de sua escolarização. Tais doações marcaram bastante os sujeitos, que se lembraram das docentes com muito afeto. No segundo segmento do fundamental, esses dois sujeitos utilizaram livros didáticos de Língua Portuguesa e todo o conteúdo foi copiado da lousa ou na biblioteca pública.

Interessante ressaltar que, para os 3 sujeitos - Malik, Taiko e Zapata - que vivenciaram uma maior restrição de acesso a material impresso, o livro didático configurou-se como importante fonte de textos. No Ensino Fundamental, Malik e Zapata lembram-se de ter lido com prazer as narrativas curtas da cartilha. No Ensino Médio, Malik leu com muito interesse textos de livros didáticos de Geografia. E Taiko leu também livros didáticos e paradidáticos usados, alguns dos quais eram de Ensino Superior - de Medicina, por exemplo - e, portanto, incompreensíveis para uma criança. Ainda assim, Taiko os leu e guardou, com o objetivo de relê-los.

Dois sujeitos - Álvares e Beatriz - tiveram farto acesso a literatura infantil e juvenil por intermédio da família e da biblioteca pública. Beatriz fez uso também da biblioteca escolar do segundo segmento do Ensino Fundamental até o primeiro ano do Ensino Médio. Dois outros pesquisados - Taiko e Malik - leram obras de literatura infantil e juvenil por meio da biblioteca escolar, mas com restrição de circulação de acervo e de forma não contínua. Taiko teve acesso a partir do $2^{\circ}$. segmento do Ensino Fundamental e Malik, entre a $3^{\text {a }}$. e a $5^{\text {a }}$. séries. Na $6^{\text {a }}$. série, o primeiro dos três anos em que Malik estudou em Cidade Tiradentes, numa escola sem biblioteca, o sujeito ficou muito impressionado com o fato de tirar uma nota baixa justamente por não poder adquirir e ler um livro. Taiko também se recorda de ter lido uma obra de literatura infantil adquirida pela família a pedido da escola. Zapata parece ter lido textos de literatura infantil apenas na cartilha.

O acesso de Álvares a livros se deu por meio de sua família e pela biblioteca pública até os 17 anos. A partir dos 18, tal acesso lhe foi franqueado também pelo grupo de pares e pela biblioteca da universidade. Zapata leu livros por intermédio de sua família, da biblioteca pública, do grupo de pares (rap, militância) e, posteriormente, já depois dos 25 anos, na 
biblioteca da universidade. O acesso de Beatriz se deu pela família, biblioteca pública e biblioteca escolar, amigos na escola, o namorado, e, mais recentemente, a partir da mudança para Cidade Tiradentes, pela biblioteca comunitária, a BCST. Taiko fez uso da biblioteca escolar e da biblioteca comunitária. O acesso de Malik a livros foi mais restrito. Ele se deu por meio de empréstimos junto ao grupo de pares (trabalho, rock, rap, militância) e aos professores no curso pré-vestibular, e compras em sebos. Posteriormente, fez uso muito intenso da biblioteca da universidade.

\subsubsection{O acesso a material impresso: comparando os grupos A e B}

De modo geral, os 8 leitores do grupo A parecem ter tido acesso mais restrito, mais descontínuo e mais tardio que os 5 sujeitos do grupo B. Nesse segundo grupo, todos os 5 sujeitos estiveram envolvidos em práticas de leitura bem precocemente e parecem não ter se afastado dessas práticas.

Temos a impressão de que o fato de o acesso a material impresso ter se dado mais tarde no grupo A de leitores e de eles não terem lido gibis, literatura infantil e juvenil talvez tenha contribuído para a não superação de dificuldades quanto à compreensão da linguagem ou da temática de literatura, dificuldades essas apontadas pelos sujeitos, as quais serão discutidas posteriormente. Ora, a mediação de leitura que se estabeleceu na BCST, normalmente a partir dos 17 anos ou do final da escolarização básica, com os sujeitos que não tinham tido desenvolvido muitas práticas de leitura antes, não promoveu a leitura de entretenimento ou a leitura literária, mas uma leitura "engajada", mais voltada a uma forma alternativa de compreensão da realidade e a um projeto de transformação social. Assim, a maior parte dos sujeitos do grupo A está hoje disposto a ler obras complexas - e às vezes um tanto herméticas - de Filosofia e Sociologia, mas não obras de literatura brasileira. Além disso, dificuldades de compreensão das obras de Ciências Humanas que alguns sujeitos do grupo A apresentem são intensamente trabalhadas nos grupos de estudo do Força Ativa. O mesmo não se dá com as obras de literatura.

Por outro lado, 4 sujeitos do grupo A - Álvares, Beatriz, Malik e Taiko - ao entrarem em contato com a BCST, já eram leitores bastante experientes e já incluíam em seu leque de leituras a literatura, na acepção de Soares (no prelo). Assim, beneficiam-se do acervo da BCST, mas não é graças ao contato com a BCST que vêm a se tornar leitores, como acontece com a maior parte dos sujeitos do grupo A. Zapata, também alocado no grupo A, participou da própria gênese do Força Ativa e da BCST e deveria supostamente estar mais envolvido 
com leituras de ciências humanas. No entanto, a graduação recente em Letras parece ter contribuído fortemente para sua apreciação de literatura. No ambiente da BCST, os leitores mais experientes e que tinham tido mais acesso a material impresso, como Álvares, Malik e Zapata, conciliam as leituras de ciências humanas e as de literatura.

\subsection{A mediação de leitura no âmbito da família}

Procurei analisar a seguir qual foi a mediação de leitura exercida pela família, se havia práticas de leitura nesse ambiente e quais eram a sua freqüência, que tipo de materiais e portadores circulavam no ambiente doméstico, quais eram as concepções dos atos de leitura e escrita presentes na família, quem fazia a mediação de leitura e como e com que freqüência tal mediação era feita. Para favorecer a visualização, apresento a seguir dois quadros sinópticos com os dados dos sujeitos do grupo A e do grupo B. 


\section{MEDIAÇÃO DE LEITURA NO ÂMBITO DA FAMÍLIA - GRUPO A (Leitores)}

\begin{tabular}{|c|c|c|c|c|c|}
\hline Sujeito & $\begin{array}{l}\text { Qual foi a mediação exercida pela família? } \\
\text { Quem fazia essa mediação? }\end{array}$ & Como e com que freqüiência? & $\begin{array}{l}\text { Havia práticas } \\
\text { de leitura na } \\
\text { família? }\end{array}$ & $\begin{array}{l}\text { Qual a } \\
\text { freqüiênci } \\
\text { a dessas } \\
\text { práticas? }\end{array}$ & $\begin{array}{l}\text { Quais as concepções dos } \\
\text { atos de leitura e escrita? }\end{array}$ \\
\hline AK47 & $\begin{array}{l}\frac{\text { Mãe }}{\text { Incentivo à escolarização }} \\
\frac{3 \text { irmãos mais velhos }}{\text { Aparentemente nenhum incentivo direto, mas ele }} \\
\text { presenciou discussões de rappers sobre a importância } \\
\text { da leitura, o que despertou sua curiosidade. } \\
\text { Modelos de leitores de livros. }\end{array}$ & $\begin{array}{l}\text { Acompanhamento do aproveitamento escolar } \\
\text { embora não alfabetizada } \\
\text { Orgulho dos filhos mais velhos já terem concluído } \\
\text { o ensino médio. } \\
\text { Constante. } \\
\text { Mediação sem pressão. } \\
\text { Constante. }\end{array}$ & $\underline{\text { Irmãos }}$ & Diária & $\begin{array}{l}\text { Emancipação econômica } \\
\text { Ascensão social }\end{array}$ \\
\hline ANDRÉ & $\begin{array}{l}\text { Mãe } \\
\text { Incentiva escolarização, mas desencoraja leitura que } \\
\text { não seja a de livros didáticos }\end{array}$ & & & & $\begin{array}{l}\text { Apenas a leitura para estudar } \\
\text { vale. }\end{array}$ \\
\hline DANDARA & $\begin{array}{l}\text { Mãe } \\
\text { Apenas trazia os livros a ela doados, mas não } \\
\text { incentivava. }\end{array}$ & Ocasional & & & \\
\hline FRIDA & $\begin{array}{l}\text { Pai e mãe } \\
\text { Aquisição de gibis a partir da alfabetização } \\
\text { Incentivo à leitura e à escolarização } \\
\text { Pai } \\
\text { Aquisição de paradidáticos } \\
\frac{\text { Mãe }}{\text { Modelo de leitora }}\end{array}$ & & $\begin{array}{l}\text { Mãe } \\
\text { Leitura de jornais } \\
\text { e revistas } \\
\text { Pai } \\
\text { Jornal }\end{array}$ & $\begin{array}{l}\text { Ocasional } \\
\text { Ocasional }\end{array}$ & $\begin{array}{l}\text { Mãe } \\
\text { Leitura para aprimorar escrita e } \\
\text { obter informação. }\end{array}$ \\
\hline LAÍS & $\begin{array}{l}\text { Mãe } \\
\text { Incentivo à escolarização } \\
\text { Interlocutora (ouvinte) da filha sobre leituras } \\
\text { Desestímulo à leitura em demasia } \\
\text { Retoma os estudos } \\
\text { Prima } \\
\text { Modelo de estudante, de leitora e de sucesso } \\
\text { Incentivo à escolarização e à leitura } \\
\text { Auxílio quanto à leitura e à escrita } \\
\text { Acompanhamento do desempenho escolar }\end{array}$ & $\begin{array}{l}\text { Orientação sobre a importância da educação e do } \\
\text { esforço } \\
\text { Interlocução para evitar que filha fique } \\
\text { complexada com dificuldade de aprendizagem } \\
\text { Constante } \\
\text { Ocasional }\end{array}$ & $\underline{\text { Prima }}$ & Constante & $\begin{array}{l}\text { Emancipação econômica e } \\
\text { ascensão social } \\
\text { Leitura em demasia acarreta } \\
\text { insanidade mental }\end{array}$ \\
\hline
\end{tabular}




\begin{tabular}{|l|l|}
\hline MARIA & $\begin{array}{l}\text { Mãe } \\
\text { Forte incentivo à escolarização } \\
\text { Desestímulo à leitura em demasia (a partir do encontro } \\
\text { com a BCST) } \\
\text { Irmão }\end{array}$ \\
\hline Incentivo à escolarização e emancipação econômica \\
\hline MARLEY & $\begin{array}{l}\text { Mãe } \\
\text { Incentivo à escolarização } \\
\text { Modelo de boa aluna }\end{array}$ \\
& $\begin{array}{l}\text { Pai } \\
\text { Incentivo à escolarização e à leitura }\end{array}$ \\
& $\begin{array}{l}\text { Mãe } \\
\text { Forte incentivo à escolarização } \\
\text { Fornecimento de livros infantis e incentivo à leitura } \\
\text { Modelo de leitora, de consulente de biblioteca e de } \\
\text { estudante } \\
\text { Aquisição de gibis e revistas } \\
\text { Irmã mais velha }\end{array}$ \\
\hline $\begin{array}{l}\text { Incentivo à escolarização } \\
\text { Idas à biblioteca. } \\
\text { Modelo de leitora } \\
\text { Pai }\end{array}$ \\
\hline $\begin{array}{l}\text { Desestímulo à leitura em demasia } \\
\text { Primos }\end{array}$ \\
$\begin{array}{l}\text { Troca de gibis com os primos } \\
\text { Tia }\end{array}$ \\
\hline $\begin{array}{l}\text { Modelo de leitora } \\
\text { Recomendação e troca de livros. }\end{array}$ \\
\hline
\end{tabular}

Repreensão severa à indisciplina ou ao mau desempenho. Constante.

Aquisição de material paradidático com grande esforço pessoal. Freqüente.

\section{$\underline{\text { Mãe }}$}

Acompanhamento do aproveitamento e

recomendações de melhora da disciplina.

Encaminhamento para psicólogo, com resultados positivos.

Não aprovação de entrada no mercado de trabalho até os 18 anos.

Pai

Auto-crítica quanto ao fato de não ter estudado mais

Crítica às pessoas que desconhecem seus direitos por não lerem sobre eles.

\section{$\underline{\text { Mãe }}$}

Acompanhamento de tarefas escolares

Leitura e explicação de livros

Incentivo à leitura pela filha

Contar à filha sobre o livro q estava lendo

Leituras em conjunto com as filhas em ambiente de intimidade e afetividade

Diário

Irmã mais velha

Acompanhamento de tarefas escolares

Interlocução sobre leituras

$\underline{\text { Pai }}$

Ocasional.

Primos e Tia

Diária

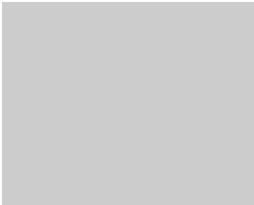

\section{Mãe}

Trechos da Bíblia

Pai

Livros de

faroeste,

atualidades,

Código de Defes

do Consumidor,

leis trabalhistas.

\section{Mãe}

Livros e revistas

.

Irmã mais velha

Livros e revistas

\section{Pai}

Jornais no

trabalho

Primos

Tia

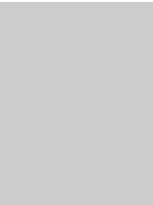

Leitura para escolarização

Leitura em demasia acarreta

insanidade mental

Ocasional

Mais

freqüiente

que a mãe.

Prazer e obtenção de

conhecimento

Diária
Diária
Diária
Diária
Diária

Lazer / Prazer

Abertura da mente 


\section{MEDIAÇÃO DE LEITURA NO ÂMBITO DA FAMÍLIA - GRUPO B (Leitores de literatura)}

\begin{tabular}{|c|c|c|c|c|c|}
\hline Sujeito & $\begin{array}{l}\text { Qual foi a mediação exercida pela família? } \\
\text { Quem fazia essa mediação? }\end{array}$ & Como e com que freqüiência? & $\begin{array}{l}\text { Havia } \\
\text { práticas de } \\
\text { leitura na } \\
\text { família? }\end{array}$ & $\begin{array}{l}\text { Qual a } \\
\text { freqüiênc } \\
\text { ia dessas } \\
\text { práticas? }\end{array}$ & $\begin{array}{l}\text { Quais as concepções dos } \\
\text { atos de leitura e escrita? }\end{array}$ \\
\hline ÁLVARES & $\begin{array}{l}\text { Mãe } \\
\text { Incentivo à escolarização. } \\
\text { Incentivo à leitura inicialmente. } \\
\text { Depois, desestímulo à leitura em demasia. } \\
\text { Pai } \\
\text { Modelo de estudante prodigioso. } \\
\text { Exigência de excelente aproveitamento. } \\
\text { Acesso pela oralidade a livros que o sujeito leria } \\
\text { depois. } \\
\text { Avó paterna } \\
\text { Modelo de leitora de variada gama de livros, incluindo } \\
\text { os clássicos literatura. } \\
\text { Politização precoce e educação espiritualista } \\
\text { Sentido de missão do homem de melhorar o mundo } \\
\text { Relatos sobre o caráter prodigioso do pai. } \\
\text { Acesso pela oralidade a livros que o sujeito leria } \\
\text { depois. } \\
\text { Tias paternas } \\
\text { Modelos de leitoras. } \\
\text { Dão acesso a leituras de contra-cultura e a variada } \\
\text { gama de leituras (ficção científica, best-sellers etc) } \\
\text { Acesso pela oralidade a livros que o sujeito só leria } \\
\text { depois. }\end{array}$ & $\begin{array}{l}\text { Acompanhamento de tarefas. } \\
\text { Exigência de excelente aproveitamento. } \\
\text { Diária. } \\
\text { À distância, por intermédio da mãe. } \\
\text { Presenciando conversas do pai com outros adultos } \\
\text { leitores. } \\
\text { Conversas da avó com o sujeito sobre livros. } \\
\text { Presenciando conversas da avó com outros adultos } \\
\text { leitores. } \\
\text { Diária, nas férias de inverno e de verão, até os } 17 \\
\text { anos, e eventuais vindas da avó para São Paulo. }\end{array}$ & $\begin{array}{l}\text { Pai } \\
\begin{array}{l}\text { Livros, jornais, } \\
\text { revistas } \\
\text { Diária }\end{array} \\
\frac{\text { Avó }}{\text { Livros, jornais, }} \\
\text { revistas }\end{array}$ & Diária & $\begin{array}{l}\text { Prazer do conhecimento. } \\
\text { Prazer estético. } \\
\text { Leitura para a transformação da } \\
\text { realidade. } \\
\text { Emancipação econômica. }\end{array}$ \\
\hline BEATRIZ & $\begin{array}{l}\text { Mãe } \\
\text { Incentivo à leitura. } \\
\text { Incentivo à escolarização. } \\
\text { Modelo de leitora de livros. } \\
\text { Modelo de consulente de biblioteca. }\end{array}$ & $\begin{array}{l}\text { Leituras compartilhadas, para entretenimento ou } \\
\text { para auxiliar filhas em tarefas escolares. Constante. } \\
\text { Leitura na companhia das filhas no tempo livre, } \\
\text { explicando-lhes o que estava lendo, em ambiente } \\
\text { de afetividade. (Diária) } \\
\text { Idas com filhas a bibliotecas. (Semanal) } \\
\text { Trazer livros da biblioteca para as filhas. } \\
\text { (Semanal) } \\
\text { Trazer livros da escola. } \\
\text { Diário }\end{array}$ & $\begin{array}{l}\frac{\text { Pai }}{\text { Jornal }} \\
\text { Mãe } \\
\text { Livros } \\
\text { Tia } \\
\text { Livros } \\
\underline{\text { Primos }} \\
\text { Gibis } \\
\text { Prima Raquel } \\
\text { Livros }\end{array}$ & $\begin{array}{l}\text { Ocasional } \\
\text { Diária } \\
\text { Diária } \\
\text { Diária } \\
\text { Diária }\end{array}$ & $\begin{array}{l}\text { Leitura pelo prazer da evasão. } \\
\text { Leitura pelo prazer do } \\
\text { conhecimento. }\end{array}$ \\
\hline
\end{tabular}




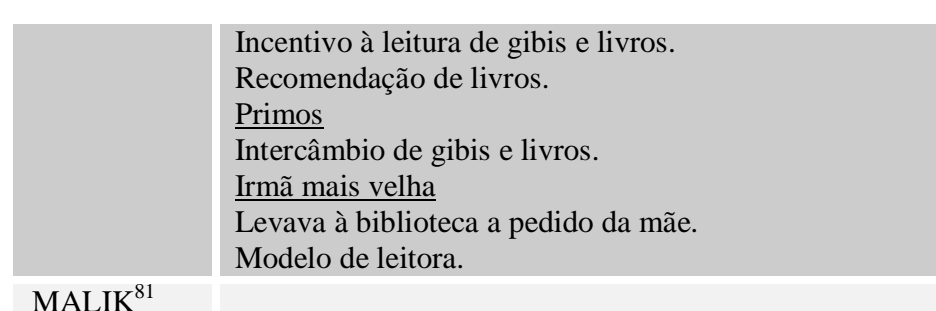

\section{MALIK $^{81}$}

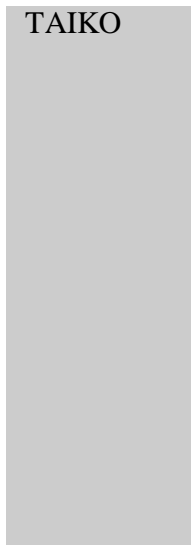

ZAPATA

\section{$\underline{\text { Pai e mãe }}$ \\ Incentivo à escolarização.}

Incentivo à leitura da Bíblia desde tenra infância, e

explicação de trechos.

Idas à igreja, onde a Bíblia era lida, explicada ou

interpretada.

Modelo de leitor da Bíblia.

Modelo de estudante ao retomar os estudos

Mãe

Incentivo à escolarização

Desencoraja leitura em excesso.

Primos

Leitores de gibis

\section{Mãe}

Incentivo à escolarização até a faculdade.

Irmãos mais velhos

Incentivo à escolarização.

Modelos de bons alunos.

Incentivo à leitura.

Modelos de leitores de gibis, revistas e livros.
De sexta a domingo, semanalmente, dos 15 anos em diante.

Diário (eram vizinhos)

Semanal

Adiamento da inserção no mercado de trabalho Leitura de trechos da Bíblia em voz alta para as

filha.

Diário

Acompanhamento das tarefas escolares

Antecipação de algumas tarefas da alfabetização

Exigência de excelente aproveitamento.

\section{Ocasional}

Exigência de bom aproveitamento. Adiamento da inserção no mercado de trabalho ou interrupção se este prejudicasse o aproveitamento escolar.

Alfabetização e noções de matemática antes de entrar na escola.

Discussão das narrativas curtas da cartilha entre os irmãos, dando tarefas de escrita.

Irmão chato, mas legal. Liam muito. Algo natural e agradável. Constante.
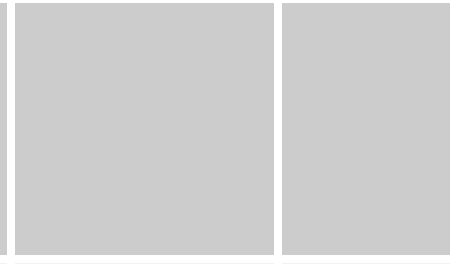

\section{Pai e mãe}

Sim. Da Bíblia.

Diária

várias

vezes ao

dia.

\section{Divina.}

Leitura para acessar a sabedoria

Emancipação econômica e

ascensão social.

\section{Pai}

Material didático

quando retoma

estudos.

\section{Pai}

Livros de faroeste

Irmãos

Revistas, gibis,

livros

Diária

Leitura por prazer.

Leitura para emancipação do ser

humano (militância)

\footnotetext{
${ }^{81}$ A falta de dados sobre a mediação de leitura pela família de Malik deve-se ao fato de eu não ter depreendido de seu depoimento quaisquer práticas ou concepções de leitura e nem mesmo atitudes de mobilização escolar.
} 


\subsubsection{A mediação de leitura pela família - Grupo A (os leitores)}

No grupo A, um dos aspectos mais relevantes é a inexistência ou parcimônia das práticas de leitura na família, seja porque nela havia poucos leitores, seja porque a leitura era realizada com pouca freqüência. Havia também pouca diversidade dos materiais de leitura e uma quase total ausência de livros entre tais materiais. Um terceiro aspecto que merece destaque foi que o incentivo à leitura esteve estritamente vinculado à escolarização. Assim, a intensa disseminação da concepção de leitura como fator de emancipação econômica $\boldsymbol{e}$ ascensão social sobrepujou quaisquer outras concepções. Uma quarta característica presente na maioria das famílias é que o incentivo à escolarização foi dado majoritariamente pelas mães, quer fossem ou não escolarizadas. As mães também tiveram mais práticas de leitura que os pais. Cabe ressaltar ainda o papel exercido pelos irmãos mais velhos, para a escolarização e a mediação da leitura. Pareceu-me importante também a mediação exercida por pessoas com quem o sujeito convivia mais ocasionalmente, mas que, por serem professoras, e, portanto, representantes da cultura letrada, assumiram grande importância para sua constituição leitora.

Um aspecto que chama a atenção, conforme dissemos antes, é que inexistiam ou havia poucas práticas de leitura na maioria das famílias dos sujeitos do Grupo A. Foi possível identificar práticas de leitura desenvolvidas pelos membros das famílias de apenas 5 dos 8 sujeitos - AK47, Frida, Laís, Marley e Paula. Desses 5 sujeitos, os 4 primeiros parecem ter interagido com apenas 2 ou menos leitores na família. Para 2 sujeitos - Frida e Marley - tais leitores foram os pais e mães, que liam ocasionalmente; para 1 outro entrevistado - AK47 -, apenas os irmãos, e as leituras eram diárias; 1 outra leitora - Laís - teve como modelo de leitora apenas uma prima, que via ocasionalmente; somente no caso de Paula, houve interação com um número maior de leitores: a mãe, as irmãs, a tia e os primos diariamente e pelo pai ocasionalmente.

Um segundo aspecto a ressaltar é que os materiais de leitura dos pais ou mães que desenvolviam alguma prática de leitura eram pouco diversos e raramente incluíam livros. Entre os materiais lidos pelas mães estavam a Bíblia (1 leitora), revistas (3), jornais (1) e livros (1). Entre os materiais lidos pelos pais, estavam jornais (2) e livretos de estórias de faroeste (1). De modo geral, as mães que liam pareciam fazê-lo com mais frequiência que os pais.

Um terceiro ponto relevante na mediação de leitura realizada na família de todos os sujeitos do grupo A diz respeito ao fato de o incentivo à leitura se confundir com o incentivo à 
escolarização. De modo geral, houve uma intensa valorização da educação, razão pela qual a leitura passou a ser importante. O estímulo à leitura aconteceu no bojo da aposta da família na educação, numa imensa expectativa de que a escola desse um lugar melhor aos sujeitos. Houve, assim, disseminação da concepção de leitura como fator de escolarização e, portanto, de emancipação econômica e ascensão social, presente nas famílias de 7 dos 8 sujeitos do grupo A. Numa versão exacerbada dessa concepção, o sujeito André chegou a ser proibido de ler pela mãe se não o estivesse fazendo para atender a alguma demanda escolar. A leitura sem um fim pragmático era vista por sua mãe como ócio condenável.

A predominância de tal concepção contrasta fortemente com a baixa freqüência com a qual outras concepções de leitura eram difundidas. Apenas nas famílias de 2 sujeitos - Marley e Paula - havia a concepção de leitura como fonte de lazer/prazer e para obtenção de conhecimento. Diferencio a idéia da leitura para obtenção de conhecimento da concepção anterior de leitura, mais vinculada à escolarização e ascensão social, pois aquela tem também um viés mais ligado ao prazer de conhecer, enquanto esta tem um objetivo mais pragmático. No caso de AK47, havia por parte de seus irmãos também a concepção de leitura para a emancipação do ser humano.

No caso de uma das entrevistadas - Dandara -, por meio de seu depoimento, não foi possível identificar práticas de leitura ou concepções do ato de leitura.

No grupo A, houve mais incentivo à escolarização pelas mães do que pelos pais. De fato, 7 dos 8 sujeitos (a exceção foi Dandara) mencionaram a figura da mãe, mas apenas 2 citaram o pai. Dois pesquisados referiram-se também aos irmãos e uma, a uma prima.

O estímulo à escolarização pelas 4 mães com mais anos de estudo - da $3^{\text {a }}$. série do Ensino Fundamental ao Ensino Médio - deu-se por meio de: a) difusão da idéia da importância da escola; b) acompanhamento diário de tarefas escolares até o momento em que a escolarização da mãe o permitiu; c) difusão de modelo de boa estudante. As mães de 3 sujeitos chegaram inclusive a retomar elas próprias os estudos em algum momento da trajetória escolar dos filhos. As passagens abaixo ilustram tal incentivo:

Frida: Não. Acho que é porque ela tem pouco estudo e ela percebeu, depois que eu nasci, o que eles não tiveram, eles querem que os filhos tenham. Então, minha mãe veio nessa linha, porque ela teve pouco estudo. Ela não se dedicou ao estudo e ela acha que os filhos têm que ter isso.

$[\ldots]$

Minha mãe agora é que terminou o ensino médio. Mas, na época que ela trabalhava, ela também não tinha muita escolaridade. Ela já começou a incentivar também porque ela veio terminar agora o ensino médio, mas ela sempre leu, sempre leu bastante. Não tem uma boa escrita... Hoje, acho que ela melhorou na caligrafia, o jeito de escrever, mas ela lê. Ela lê e ela entende, ela sabe discutir as coisas. 
Paula: [Quando a gente não queria ir pra escola, a minha mãe] brigava muito com a gente. Falava que não, que a gente tinha que estudar. Brigava bastante com a gente. [Você tem que ir] porque você tem que aprender, tem que ler, tem que escrever.

[...]

Minha mãe ajudava bastante [a fazer lição de casa].. Às vezes, quando a gente chegava da escola, aliás, quando ela chegava do serviço, ela ajudava a gente no dever, tipo mesmo nas coisas que a gente não entendia, que eu acho que ela tinha um pouco mais de facilidade, ela ajudava a gente.

Laís: Minha família. Nessa parte, [o que contribuiu para eu me tornar leitora] acho que foi a estrutura que a minha mãe sempre deu na educação e ela sempre falou: “Gente, educação, o estudo, nós somos humildes, mas tem que estar sempre em primeiro lugar e a gente tem que ir buscar." E a gente se mirava no exemplo dela porque ela também voltou a estudar. Não é fácil falar tudo isso e não estar fazendo. Ela é assim.

$[\ldots]$

[Quem mais me influenciou para ler foi a minha família, por causa da] da minha mãe né, não tem como, porque, se você não tiver ninguém falando para você que "Ah, se você não fizer isso, você também não vai ser instruído, né".

Marley: Ela já tinha. Ela já tinha [ensino médio antes de se casar] porque minha mãe sempre foi uma boa aluna, assim.

Ao contrário do que se poderia a princípio supor, apesar de não serem modelos de estudantes nem disporem de capital escolar para auxiliar os filhos na aprendizagem, os incentivos à escolarização das mães não alfabetizadas de 3 sujeitos - AK47, André e Maria foram muito poderosos. Justamente por não terem tido acesso à escola, tais mães atribuíram a essa instituição ainda maior importância, verbalizando a necessidade de estudar e fazendo investimentos pedagógicos:

AK47: Eu lembro que ela [minha mãe] pegava muito no pé porque ela tinha essa coisa que todo mundo tem de que você tem que estudar para ser alguém. Ela tinha essa visão comum de estudar para ser alguém. E eu lembro que ela falava que todos dos mais velhos já tinham concluído o ensino médio e então ela achava isso legal. Ela tinha orgulho disso. Ela não viu ninguém entrar na universidade. Acho que ela achava isso uma coisa muito distante. Então, ela cobrava. Ela não gostava que ninguém repetisse de ano. Se repetisse, era castigo para o ano inteiro.

André: Minha mãe falava: "André, só quando você fizer uma faculdade que eu vou morrer tranqüila".

Maria: E aí eu era sempre muito quietinha, muito medrosa, tinha medo da minha mãe. Se minha mãe tivesse qualquer reclamação, não queria saber quem estava certo: ela batia primeiro pra depois escutar. E, além de ter medo da minha mãe... Minha mãe é assim: por não ser alfabetizada, ela sempre fez questão de colocar todos nós na escola. Também nunca faltou numa reunião, sempre que precisou ela teve muito presente e tudo mais. E eu lembro que, quando eu tinha que fazer algum trabalho, alguma coisa em casa, que eu ficava olhando pro caderno sem saber o que escrever, quando ela via que a gente tinha alguma dificuldade, ela sempre vinha e pedia desculpa: "Desculpa, eu não posso ajudar porque não sei, porque eu não estudei”. E aí o que é que ela fazia? Passava aqueles vendedores de enciclopédia na porta, e ela sempre comprava, porque eles mostravam aquela enciclopédia enorme, toda colorida, vinha com o CDzinho, não sabe nem pra quê servia. [E o vendedor dizia:] "Porque seu filho vai usar até a universidade, não sei o quê". Então ela, porque achava que ia contribuir pra nossa formação, sempre comprava, fazia muito esforço, os atlas... Então, do jeito dela, ela dava esse incentivo. E minha mãe, muitas vezes, pra pagar essas enciclopédias, ela levantava cedo, ia pegar papelão, juntava latinha, ia vender. Então, todo esse esforço, essa dedicação... A figura da minha mãe é uma figura muito forte pra mim. Porque, mesmo sem ter tido essa matéria de conhecimentos, mas sempre ter dado esse... que pra mim tudo é uma coisa, o jeito dela dentro das limitações dela é... um incentivo muito grande, então... E até por ter um conflito emocional: meu pai não está aqui, não faz nada por mim; minha mãe está aqui e faz tudo. Então, isso também fazia com que... Eu sempre tive muita força de vontade pra não 
decepcionar minha mãe. E aí, na escola, eu sempre fui boa aluna, porque eu gostava também. Não tinha dificuldade de aprendizado nem nada. Eu gostava, só que eu sempre tinha em mente que eu não podia decepcionar minha mãe, que minha mãe estava fazendo tudo por mim. Então, eu ia bem na escola. Eu lembro que tinha um irmão meu que dava um trabalho do caramba, bateu até em professor e tudo mais e... eu sempre falo "não isso eu não vou fazer não", acho que por causa da referência da minha mãe também. Muito medo de apanhar, mas eu não queria decepcionar ela.

Se, por um lado, as mães de 7 sujeitos foram fortes incentivadoras de sua escolarização, as mães de apenas 2 entrevistadas - Frida e Paula - foram modelos de leitoras:

Frida: Minha mãe agora é que terminou o ensino médio. Mas, na época que ela trabalhava, ela também não tinha muita escolaridade. Ela já começou a incentivar também porque ela veio terminar agora o ensino médio, mas ela sempre leu, sempre leu bastante. Não tem uma boa escrita... Hoje, acho que ela melhorou na caligrafia, o jeito de escrever, mas ela lê. Ela lê e ela entende, ela sabe discutir as coisas.

Paula: Nossa! [A minha mãe lia] milhares [de livros por ano]. Eu sempre vi a minha mãe com muitos livros. Muitos livros.

Essas duas mães verbalizaram seu incentivo à leitura constantemente. Ambas difundiram também a concepção de leitura para obtenção de conhecimento. Uma delas verbalizou a concepção de leitura como fator de emancipação econômica e ascensão social. A segunda disseminou também a idéia de leitura como fonte de lazer/prazer ${ }^{82}$ :

Frida: Não, [a minha mãe nunca me mandou parar de ler]. Ela sempre disse que ler é bom. Às vezes, eu vejo que ela fica chateada porque eu queria ler mais e não consigo. Falta de tempo, tem barulho, porque eu tenho dois irmãos, um de 13 e um de 6, e eles são fogo. Entra e sai, entra e sai, e fala e grita e eu não consigo, não me concentro. Com muito barulho, eu não me concentro. [...] Ela sempre falava que ler é bom porque você aprende a escrever melhor e você tem informação. Ela nunca falou que ler é bom. Ela sempre falou que ler é bom por causa disso. Sempre explicou que é bom por tal coisa. Acho que [ela tem essa visão sobre leitura] porque ela tem pouco estudo e ela percebeu, depois que eu nasci, o que eles não tiveram, eles querem que os filhos tenham. Então, minha mãe veio nessa linha, porque ela teve pouco estudo. Ela não se dedicou ao estudo e ela acha que os filhos têm que ter isso.

Paula: [A minha mãe sempre falou] "Vamos ler que ler é bom e vamos estudar também que estudar é bom." [...] Acho que isso é bom. Acho que abre a mente. Ler para mim é um bom passatempo. Eu não lembro dela falar muita coisa assim pra nós... Eu lembro dela falar que "Ler é bom!" [Eu me] lembro dela [minha mãe] lendo por prazer. Mais por prazer do que na faculdade... [Minha mãe] contava [o que ela estava lendo]. Do último, O Guerreiro da Luz, ela contou bastante. Ela sentava na cama e ficava contando pra nós. [...] Às vezes, como a gente estudava no período da tarde, nós acordava de manhãzinha, ela estava sentada no quarto e aí a gente ia lá. Até mesmo quando ela chegava assim do serviço, a gente também ficava com ela bastante.

Ambas as mães forneceram material impresso às filhas, estimulando a leitura de gibis e literatura infantil. Uma delas desenvolveu atividades de leitura compartilhada com as filhas em ambiente de intimidade e afetividade, interlocução sobre as leituras, e eliminação de eventuais dificuldades de compreensão das leituras praticadas pelas filhas.

\footnotetext{
${ }^{82}$ Como modelo de estudante, é bastante provável que a mãe de Paula também tenha, ainda que silenciosamente, disseminado a concepção de "leitura para a emancipação econômica e ascensão social". Mas as concepções relatadas por Paula são a de leitura por (prazer do) conhecimento e de leitura por lazer/prazer.
} 
Uma terceira mãe não foi modelo de leitora, nem pôde sanar dificuldades de compreensão, mas foi importante interlocutora da filha - principalmente como ouvinte sobre as leituras e (dificuldades de) aprendizagem desta:

Laís: Eu lia e contava pra minha mãe e pra minha irmã o que eu lia.

$[\ldots]$

Então, a Bíblia foi sempre um incentivo pra mim. Diferenciar certas palavras. Até quando eu dizia: “Ah, mãe, você sabe que tem novela também na Bíblia?" [Ela perguntava:] "Como filha?" [E eu respondia:] "Tem novela, sobre romance, que é o canto e explica sobre romances. Mas a gente não sabe porque é outra história diferente. A gente não vê que é um romance ali acontecendo. E eu falava pra minha mãe. E ela [perguntava]: “É sério, filha?”. [E eu respondia:] É, mãe.

Apenas 2 sujeitos - Frida e Marley - mencionaram os pais como leitores. Os pais de ambos desenvolveram ocasionalmente algumas práticas de leitura por prazer/lazer e para obtenção de conhecimento. O pai de Frida lhe forneceu algum material impresso e o de Marley eventualmente verbalizou seu incentivo à leitura:

Frida: E eu me lembro que eu comecei a ler gibi, meu pai e minha mãe sempre me deu gibi da Mônica, da Magali, esses gibizinhos assim e eu comecei a ler desse jeito. Eu sempre gostei de ler [...]. Mas eu comecei lendo gibi e gosto de ler gibi ainda e história infantil também gosto.

[...]

[Meu pai começou a comprar gibi] quando eu comecei a ler, né. Com seis ou sete anos, por aí. Eu não me lembro muito bem, mas deve ter sido nessa faixa de idade. Eu acho que era.

[...]

Minha mãe lê muito. Minha mãe lê muito jornal, revista. Então, assim, de ver minha mãe lendo, eu acabei lendo também, jornal, revista. E ela gosta de ler. Eu também gosto de ler. Então, é a minha mãe. [...] O meu pai nem tanto. Acho que eu nunca vi... acho que ele lia muito mais jornal. Mas ler mesmo assim com aquela coisa de ler mesmo, não. É mais jornal que ele lia. [...] Jornal tipo assim tipo Folha de São Paulo, esses jornais assim... Diário de São Paulo, esse tipo de jornal.

$[\ldots]$

[Meu pai e minha mãe me] falavam, falavam ["filha, lê que é bom”]. Sempre incentivou a ler. Não só falou como também dava gibi para ler, historinha infantil. Minha mãe faz isso ainda com meu irmão. Pega o livro, dá na mão dele e ele está lendo, diz que tá lendo, né [risos].

$[\ldots]$

Na minha casa, não [tinha] muito livro, poucos livros. Mais era jornal, gibi, livro mesmo assim não. Meu pai chegou a comprar um dicionário, mas coisa assim para a escola mesmo, livros de pesquisa, mas não livro para ler. Tirando o gibi, que ele achava que era legal, acho que é coisa pra criança, mas nunca pensou em comprar, vai, “Ah, vi um livro, vou comprar para ela ler”. Isso não, eu não me lembro.

Marley: Meu pai depois ele começou a ler acho que de tanto minha mãe ficar chamando ele de analfabeto, de burro, de ignorante. [...] Quando os dois ficavam brigando ela começava a xingar ele. Então, ele começou a ler faroeste, meu pai sempre gostou de ler faroeste americano Texas. Eu não me lembro os outros não, mas era mais Texas. Ele gostava de ler isso aí. E assuntos gerais assim, atualidades.

É isso aí [minha mãe tinha mais escolaridade, mas quem lia mais era meu pai].

$[\ldots]$

Meu pai lia, mas uma leitura bem do gosto dele. Acho que ele lia por prazer para ele mesmo, para conhecer alguns assuntos. Até mesmo o Código de Defesa do Consumidor, Direitos Trabalhistas, meu pai entende mais que minha mãe, até hoje. Minha mãe falava: Ah! fulano está sofrendo. Ele dizia: Ah! porque é burro, porque não conhece o que está na lei. O que está na lei? - Isso, isso, isso, então as pessoas não lêem, tem que se ferrar mesmo. É que ele também ele falava como uma autocrítica, assim... se eu tivesse, ele falando assim: se ele tivesse mais tempo ele com certeza voltaria até para a escola. Mas hoje ele está de boa. 
Dois sujeitos - AK47 e Paula - relataram a atuação dos irmãos mais velhos como mediadores de leitura. Para ambos os sujeitos, os irmãos foram modelos de consulentes de biblioteca e de leitores assíduos. O contato com os irmãos se deu diariamente e o incentivo à leitura aconteceu "sem pressão", ou seja, sem uma imposição da prática ou de uma determinada concepção de leitura ao sujeito. No entanto, Paula depreendeu da prática da irmã mais velha, com quem manteve interlocução sobre as leituras, o conceito de leitura por lazer/prazer. AK47, por sua vez, testemunhou reuniões dos irmãos mais velhos sobre a importância da leitura para a emancipação do ser humano. A esse respeito, vejamos o que ambos relataram:

Paula: Tinha [uma biblioteca na Vila Formosa]. Perto da minha casa, [não na escola]. E era a minha irmã mais velha que tinha que levar a gente. A gente ia de vez em quando. [...] Ela levava. Às vezes, a gente podia trazer os livros, às vezes, não. A gente ficava até mesmo lendo lá, lá na biblioteca e aí depois dava um certo horário e a gente voltava para casa.

[...]

Não. É mais nós que incentiva ela [a irmã do meio] a ler do que ela [a gente]. Foi mais a Flávia do que ela. [...] Ela lê muita coisa. Ela senta e...

$[\ldots]$

[Quando a gente era pequena] a gente mexia bastante nos livros dela [da irmã mais velha]. Até mesmo nos livros de escola que ela deixava em cima, a gente mexia bastante. De vez em quando, ela não gostava muito não, mas a gente mexia, acabava mexendo mesmo assim.

[A gente] perguntava [coisas sobre a leitura que ela estava fazendo]! Às vezes, a gente [falava]: "Nossa... esse livro!! É bom?" Aí ela falava se era bom, se ela tinha gostado. Aí tinha livro que ela falava assim: "Nossa, é bom ler, hein? É muito bom!" E a gente acabava lendo.

AK47: Meus irmãos começaram a acumular livro em casa e eu não entendia o porquê. [...] Eram livros de economia, sociologia, filosofia. Eu não entendia porque eles liam tanto e aí eu comecei a mexer nos livros deles. Aí eu comecei a achar algumas coisas básicas sobre filosofia e sociologia. Aí eu fui me interessando cada vez mais... [As minhas práticas de leitura eram] mínimas, mínimas mesmo. Só mesmo quando eu não estava fazendo nada. Nada que eu achasse importante, não estava jogando bola, não estava na quadra, não estava na rua, não estava vendo televisão e aí eu ia procurar livro para ler.

$[\ldots]$

Então, meus irmãos começaram a acumular livros desde que eles começaram a se envolver com o movimento hiphop. Só depois de dez anos que um foi para a universidade. Isso foi no ano de 1995. Então, eles já participavam do Força Ativa, já faziam discussão sobre a importância da leitura aqui na biblioteca. Não tinha uma biblioteca aqui na Cidade Tiradentes e aí eles começaram a juntar os livros. E como eles faziam trabalhos relacionados à questão racial, à história da esquerda, eles começaram a acumular esse tipo de livro em casa. O primeiro só foi entrar na faculdade nove anos depois, no ano de1995 até o ano de 2004.

$[\ldots]$

Eu não entendia porque eles sempre falavam de Marx, tinha umas referências, mas não entendia. Já tinha ouvido na escola alguma coisa sobre socialismo, mas sem aprofundar. Mas eu tinha curiosidade de conhecer. E eu sempre gostei de temas voltados para política, sempre buscava uma leitura sobre isso.

[...]

Mas, quando eles [os meus irmãos] estavam no hiphop, desde Itaquera no ano de 1994, minha mãe foi sempre aberta a tudo isso. Ia um monte de gente em casa ensaiar músicas de rap, faziam reuniões em casa porque não tinham espaço. Minha mãe deixava, mas ela não se metia muito porque ela sempre foi malufista.

[Eu comecei a ler] pela curiosidade que eu sempre tive de conhecer a filosofia, porque eu escutava [os meus irmãos] falar[em], isso atraiu o meu gosto pela leitura, tanto que eu fui querer saber o que é filosofia, fui buscar mesmo. 
[...] Eu vou ter a experiência dos meus irmãos, o Fernando, o Zapata e o Wilson, eles sempre andavam com um livro na mão e sempre falavam da questão da leitura. Então, vou lembrar deles.

[...]

Quando você tem referências dentro da sua casa, facilita bastante, embora não é nada mecânico: um irmão fala de livro, o outro logo vai vir lendo. Não é de forma mecânica. Até porque em casa nunca teve nenhuma doutrinação de nenhuma parte, nem da minha mãe e nem dos meus irmãos, de nada. [Meus irmãos não ficavam me falando pra ler], mas você vê o cara toda hora chegando com um livro e fala de não sei quem e isso vai despertando a curiosidade. Então, é nesse sentido que a família ajudou.

Dois sujeitos - Laís e Paula - fizeram referência a primos e 1 - Paula -, a uma tia.

Para Laís e Paula, uma prima e uma tia, respectivamente, ambas professoras, foram modelos de estudantes e de leitoras. As duas incentivaram a escolarização e a leitura das entrevistadas. Uma auxiliou Laís quanto a dificuldades de leitura e escrita. A outra estabeleceu com Paula interlocução sobre leituras, recomendou-lhe e forneceu-lhe livros. A interação de Paula com a tia foi diária na infância (quando moraram no mesmo terreno) e semanal na adolescência. O contato de Laís com a prima foi muito esporádico, mas ela foi sempre objeto de conversas na família, já que constituía uma referência de escolarização e de sucesso profissional, alguém a imitar, e a quem a mãe de Laís achava que a filha "tinha puxado".

Os trechos abaixo se referem à atuação dessas duas parentas professoras:

Paula: A minha tia gostava muito de ler. Ela gostava muito de ler. Até hoje, ela gosta muito de ler. Às vezes, a gente vamos lá na casa dela, aí ela fala: "Olha, eu tenho um livro aqui em casa que é muito bom. Pode pegar, pode levar para casa, lê e depois vocês me devolvem". [...] [Ela] morava no mesmo quintal. [Ela também] comprava [gibis para os filhos dela]. A gente ia trocando. Mas nunca deu briga entre primos por causa de gibi.

$[\ldots]$

[E nós trocávamos livros] com a minha tia, né. Com a Tia Ruth. A gente trocava bastante livro com ela. Até hoje a gente troca bastante livro.

Laís: [A minha prima Fabiana] me influenciou também. Porque teve uma vez que ela chegou em mim e perguntou como eu tava na escola, principalmente na parte de português mesmo e aí eu falei pra ela: "Ah, professora", pra minha prima, porque eu chamava ela de professora, "eu sei que eu tenho uma dificuldade mesmo na redação, na escrita". E eu passei umas férias na casa dela, fiquei uns dias lá. [...] Eu tava com os meus 16 anos. Aí ela me emprestou um livro sobre redação, infantil mesmo, aí eu fui lendo. E ela falou pra mim: "Não precisa se preocupar porque é devagarzinho que a gente vai aprendendo. Vai lendo também". E ela queria dar um auxílio também pra mim fazer... como é que fala? Não é supletivo. É que antigamente tinha magistério na parte de língua portuguesa. Então, ela queria que eu fizesse. Mas eu falei pra ela: "Como eu tenho esse grave erro, acho que não dá pra mim prestar". Aí ela falou assim pra mim: "Não, dá sim! Você estuda! Dá sim!". E ela me incentivou nisso. Como ela mora longe, eu falei pra ela que eu não ia optar porque não era uma área que eu ia me sair bem, não sei. Tava tendo concurso e tudo. Mas aí ela me incentivou mais ainda. Quando ela vinha em casa, ela tomava às vezes... ela me fazia escrever as palavras que eram difíceis na redação, via os erros, me explicava. Então, assim, foi um apoio a mais pra mim, um incentivo a mais... [Ela] gosta de ler. Ela é muito esforçada. Minha mãe sempre falou pra mim dessa prima dela. Eu me espelhei muito nessa minha prima, porque ela sempre foi de ler, de estudar, sempre foi esforçada mesmo. Ah, ela gosta.

Eu gostava também de pegar coisas, de querer aprender, principalmente na Bíblia, que era a primeira coisa. Aí eu falava: "mas será que eu sou normal?" Porque a minha irmã não gostava de ler muito. Ela era mais de escrever. Meu irmão também não. E aí eu pensava: De quem eu puxei esse negócio de querer aprender, aprender a ler, saber pronunciar a palavra ou escrever melhor? E a minha mãe falou: da sua prima. Essa nossa prima sempre foi esforçada. 
Em síntese, no grupo $\mathrm{A}$, os depoimentos apontam que as práticas de leitura nas famílias da maioria dos sujeitos inexistiram ou foram parcimoniosas, devido ao número reduzido de leitores, à baixa freqüência com que a leitura era realizada. Eles evidenciam ainda a pouca diversidade dos materiais de leitura e a quase total ausência de livros. O incentivo à leitura esteve muito ligado à aposta na escolarização como fator de emancipação econômica e ascensão social, concepção de leitura que sobrepujou quaisquer outras. O estímulo à escolarização e o investimento pedagógico foram de responsabilidade principalmente das mães, quer fossem ou não escolarizadas. As mães alfabetizadas também tiveram mais práticas de leitura que os pais. Os relatos evidenciaram ainda o papel exercido pelos irmãos mais velhos, para a escolarização e a mediação da leitura e a mediação exercida por pessoas que, por serem professoras, e, portanto, representantes da cultura letrada, tornaram-se uma referência para os sujeitos.

\subsubsection{A mediação de leitura pela família - Grupo B (os leitores de literatura)}

Depreende-se dos depoimentos dos sujeitos do grupo B que houve, em suas famílias, mais práticas de leitura em dois aspectos: um número maior de praticantes e com muito maior freqüência. Uma outra característica das práticas leitoras das famílias do grupo B é a maior diversidade de materiais de leitura e a presença muito forte do livro entre tais materiais. Um terceiro traço muito relevante nas famílias desse grupo é que, a despeito de ter havido forte incentivo à escolarização, o estímulo à leitura não esteve tão estritamente vinculado a tal escolarização. Embora o incentivo à escolarização tenha sido feito principalmente pelas mães, a mediação de leitura foi exercida por um número maior de membros da família, que difundiram concepções de leitura também mais diversas. Outro aspecto importante é que o fato de haver mais leitores na família favoreceu que o sujeito presenciasse mais momentos de interlocução sobre leituras que ele próprio ainda não havia realizado.

Nos depoimentos de 4 dos 5 sujeitos do grupo B, foi possível identificar a existência de mais práticas de leitura no âmbito da família, sob dois pontos de vista: havia um número maior de leitores e as práticas eram realizadas com maior frequiência. De fato, eles parecem ter convivido com ao menos três pessoas na família que liam e o faziam diariamente. No caso de Zapata, foram o pai e os irmãos. No da jovem Taiko, o pai, a mãe e os primos. No de Álvares, foram o pai, a avó e as tias. No de Beatriz, a mãe, as irmãs, a tia e os primos. O pai de Beatriz lia com menos freqüência. No caso de 1 dos sujeitos - Malik -, aparentemente não havia práticas de leitura na família. 
Houve também uma maior diversidade de materiais de leitura e a presença do livro como o material mais frequientemente lido. Entre os materiais de leitura utilizados pela família, os sujeitos citaram: livros (8 leitores), revistas (3 leitores), jornais (3 leitores) e a Bíblia (2 leitores).

No grupo B, o incentivo à leitura não esteve tão estritamente vinculado à escolarização, embora a concepção dos atos de leitura mais comum nas famílias de 3 sujeitos - Álvares, Taiko e Zapata - dizia respeito à busca de escolarização, a qual teria como conseqüência a emancipação econômica e ascensão social.

Em segundo lugar, entre as concepções de leitura mais comuns, vieram a leitura por lazer/prazer - presente na família de Beatriz e Zapata - e a leitura para obtenção de conhecimento - difundida na família de Álvares e Beatriz. Também em segundo lugar, esteve uma espécie de concepção negativa da leitura quando praticada em demasia, verbalizada por algum membro da família de 3 sujeitos - Álvares, Beatriz e Taiko -, geralmente aquele que desenvolvia menos práticas de leitura. A leitura em demasia seria fator de insanidade mental.

Em terceiro lugar, apareceram duas concepções de leitura que, embora tenham sido nomeadas de forma diferente pelos sujeitos - leitura para a emancipação do ser humano por Zapata e leitura para a transformação da realidade por Álvares -, assemelham-se por terem em comum um posicionamento político de esquerda, posicionamento esse sempre explícito tanto no discurso dos irmãos do primeiro sujeito, quanto na fala da avó e das tias do segundo.

Em último lugar, está a concepção de leitura para acessar a sabedoria Divina, difundida na família de Taiko.

Nesse grupo, ao contrário do que aconteceu no grupo A, não foi possível generalizar se foram os pais ou as mães que desenvolveram mais práticas de leitura.

A mediação de leitura nas famílias de 4 sujeitos - Álvares, Beatriz, Taiko e Zapata parece ter sido exercida por vários membros da família. Não houve preponderância de mediação pelas mães, como aconteceu no grupo A de leitores. Na família de 2 sujeitos Álvares e Beatriz - ao menos 5 pessoas foram modelos de leitores: o pai, a avó e as tias paternas de Álvares, que liam variada gama de obras, em especial livros; e a mãe, a tia materna, uma prima e a irmã mais velha de Beatriz. Na família de outra entrevistada - Taiko o pai, a mãe e os primos liam. Na família do quarto sujeito - Zapata -, o pai tinha algumas práticas de leitura e ao menos dois irmãos foram modelos de leitores.

Também no grupo B de leitores, o estímulo à prática da leitura por alguns mediadores vinculou-se ao incentivo à escolarização, tendo havido disseminação da concepção de leitura 
como fator de emancipação econômica e ascensão social. Os trechos abaixo ilustram tal difusão pelas mães de 3 sujeitos - Álvares, Taiko e Zapata:

\footnotetext{
Álvares: Eu acredito que, no imaginário das pessoas, principalmente as pessoas que não tiveram acesso ao estudo, o imaginário das pessoas é que você lendo, você vai conseguir galgar um espaço na sociedade e se você adquirir conhecimento vai te fazer com que você sofra menos e que no futuro você vai estar numa posição social mais estável.

$[\ldots]$

Acho que depende da leitura: se a leitura era com o objetivo de ganhar dinheiro, era uma coisa. Agora, leitura com prazer de ler e para ter conhecimento que não vai ajudar em algo, é outra. Tanto que minha mãe era pragmática. E as outras pessoas dava para perceber que elas gostavam pelo prazer estético, sem finalidade, só pelo prazer estético.

$[\ldots]$

Eu acredito que a idéia dominante, eu creio que a motivação é se dar bem na vida, ter uma vida agradável, buscar a felicidade. A leitura ainda é vista como um acesso para você ter condições melhor de vida.
}

Taiko: [...] Nossa, eu não sei de onde vem [esse meu gosto por ler e estudar]. Acho que minha mãe puxou mais para minha vó, a mãe dela já falecida, a mãe dela era super batalhadora, tinha muitos filhos e fazia tudo, dentro de casa, na roça. Depois que minha avó morreu, minha mãe teve que vir para a cidade, trabalhar em casa de família. Então, acho que foi esse processo que fez ela enxergar a vida, com uma outra visão, entendeu, que ela precisava de estudo, que os patrões dela que estavam ali pagando ela [porque] eles tinham estudo, pra ter um espaço...

Zapata: [Minha mãe sempre falava "Você tem que estudar" pelos motivos] mais ou menos do geral do pessoal hoje. Tem que estudar para você ser alguém, para ter uma profissão e tal.

Ao falar do estímulo à escolarização, 4 sujeitos aludiram à figura da mãe e 2 citaram o pai. Um pesquisado relatou a atuação dos irmãos e o outro, da tia.

O incentivo à escolarização pelas 3 mães que freqüentaram a escola deu-se por meio de: a) difusão da idéia da importância da escola; b) exigência de excelente aproveitamento; c) acompanhamento diário de tarefas escolares até o momento em que a escolarização da mãe o permitiu; d) difusão do modelo de boa estudante. As mães de 3 dos 5 sujeitos do grupo B retomaram os estudos depois de casadas.

As passagens abaixo ilustram o estímulo à escolarização por essas 3 mães:

\footnotetext{
Álvares: Era aquela visão de só criar filho, só cuidar, reclamar, cobrando, eu só podia assistir o programa de televisão se eu fizesse a lição. [...] Quando eu tirei a nota vermelha, a primeira, só foi um ano na sétima série, se eu tirasse qualquer nota abaixo de... se fosse $\mathrm{C}$, eu já apanhei porque eu tirei $\mathrm{C}$ uma vez... já ia em cima porque era menos. Eu dizia: mas é azul, mãe. Mas mesmo que fosse nota azul abaixo de seis não servia para ela.

$[\ldots]$

Quando ela era jovem. Depois que ela teve filhos que ela terminou o primeiro grau e estava com projeto de fazer o segundo grau. Então, ela falava assim que, em certos pontos, que: "daqui eu não posso te ajudar". Tipo, eu fiquei sozinho, porque o meu pai tinha conhecimento, mas ele não me ajudava e minha mãe não tinha instrumentos intelectuais mesmo, ela não podia, então ela ficava meio até... Até a sétima série, sexta série assim, ela me ajudou bastante. Mas depois aí já ficou aquém das possibilidades dela. [...] Minha mãe todos os dias ela olhava os cadernos, todos os dias ela via todos os bilhetinhos, todas as reclamações. Eu sempre fui um aluno acho que exigente também, eu tirava as melhores notas também, sempre fui quietinho, nunca dei trabalho.
} 
Beatriz: Na segunda série mesmo, a gente estava e ela [a minha tia] dava aula para primeira série e aí a gente foi e a gente fazia birra e minha mãe brigava. Ela [a minha mãe] falava: "Não é assim...Não é assim”. E aí depois que a gente repetiu mesmo, foi aí que a gente pegou firme na escola. Que aí que eu ia sem chorar. Eu sabia que eu tinha que ir para escola.

Taiko: Olha, desde criança, como eu disse, eu gosto de ler e escrever. Então, eu exigia da minha mãe e minha mãe também exigia de mim. Então, quem me ajudou bastante mesmo foi a minha mãe. Minha mãe não deixava somente ao sabor dos professores. Ela também me ajudava, porque isso é super importante na vida de uma pessoa, de um jovem, de uma criança. Os pais também têm que dar uma parte da colaboração, entendeu? E minha mãe me ajudou bastante. [Ela] fazia tarefas para eu fazer, fazia textos para eu fazer, fazia aquelas letras cheias de pontinhos, para eu escrever em cima, sabe?

$[\ldots]$

Nossa, eu não sei de onde vem [o meu gosto por estudar e ler]. Acho que minha mãe puxou mais para minha vó, a mãe dela já falecida, a mãe dela era super batalhadora, tinha muitos filhos e fazia tudo, dentro de casa, na roça. Depois que minha avó morreu, minha mãe teve que vir para a cidade, trabalhar em casa de família. Então, acho que foi esse processo que fez ela enxergar a vida, com uma outra visão, entendeu, que ela precisava de estudo, que os patrões dela que estavam ali pagando ela, eles tinham estudo, pra ter um espaço...

Ainda a respeito do estímulo dado à escolarização pela mãe, no caso da mãe do quarto sujeito, que não era alfabetizada, isso consistiu da difusão da idéia da importância da escola e da exigência de excelente aproveitamento, dois aspectos também presentes na mediação exercida pelas mães escolarizadas deste grupo e nas mães dos sujeitos do grupo A:

Zapata: Eu nunca gostei de escola. Por outro lado, eu sabia a importância da escola porque tudo da minha mãe era escola. Você já nascia ouvindo isso: "Tem que estudar, tem que estudar...". [Minha mãe falava que eu tinha que estudar pelos motivos] mais ou menos do geral do pessoal hoje. Tem que estudar para você ser alguém, para ter uma profissão e tal. Eu estava até comentando com o Fernando esses dias que a minha mãe sempre comentava esse negócio da colação de grau, não era só ensino médio, fundamental. O objetivo dela [era que todo mundo fosse pra faculdade] junto.

Outro aspecto relevante no incentivo à escolarização dado pelas figuras maternas está presente em 2 das 4 mães, independentemente do grau de escolaridade delas. Trata-se do adiamento da inserção do sujeito no mercado de trabalho:

Taiko: Tem gente que passa necessidade, tem que trabalhar e estudar. Outros têm filhos e têm que dividir espaço de tempo pra tudo. Enquanto eu tiver oportunidade de estudar, eu vou estudar.[...] [Minha mãe fala pra mim] que não [posso trabalhar], que enquanto ela puder me sustentar, é só estudar.

Zapata: É. E eu trabalhei muito à noite, porque, assim, até a [minha filha] Luana nascer, nossa situação era muito ruim lá na minha família. Só que a minha mãe era assim: a gente trabalhava, mas, se começasse a prejudicar, ela mandava sair e ponto final. Então, eu cheguei até a trabalhar com meu pai na oficina para ganhar um dinheirinho, na padaria antes, quando eu era adolescente. Lembra que eu falei que mudei de escola e fui trabalhar numa fábrica de salgadinho, mas aí, se começasse a atrapalhar, eu saía. Mas aí a situação mudou, né.

O estímulo à escolarização foi dado pelos pais de 2 sujeitos - Álvares e Taiko -, mas 
de modo mais indireto que aquele das mães. No entanto, ambos os pais foram também modelos de estudantes - o de Álvares por seu caráter muito prodigioso, que se tornou uma espécie de lenda na família, e o de Taiko, por retomar os estudos depois de adulto e almejar inclusive o ingresso no Ensino Superior:

\begin{abstract}
Álvares: Complicado, né, mas aí que entra a história do meu pai falar "vai estudar". Ele tinha esse incentivo assim, e ele cobrava da minha mãe também. Ele tinha esse incentivo. [...] Ele passava toda a responsabilidade para a mulher e ele era o mantenedor da casa, portanto só ele dava o dinheiro. Então, ele não queria ter o acesso aos problemas corriqueiros do dia a dia que serviria só para quem está lá, que era minha mãe. Então, ele fazia uma cobrança indireta, a cobrança era indireta.

[...]

Meu pai, a partir aos quatro anos de idade, ele já era alfabetizado, tanto é que ela [a minha avó] contava as lendas do meu pai, a biografia do meu pai. E, então, eu era a sombra, eu me sentia muito... Eu queria ser igual ao meu pai, por todas as histórias que contavam, porque ele tinha sido alfabetizado aos quatro anos de idade e porque ele era o melhor na escola, o melhor em tudo que ele fazia, o melhor do exército. [...] Ele era superdotado e ele era, contas de matemática, essas coisas, ele fazia sem calculadora. A gente tinha uma referência de um ser humano que você quer buscar sombra... ficar como uma sombra, né.

Taiko: [O meu pai quer fazer faculdade] porque ele quer mudar de vida. Teve uma certa fase que minha mãe falava "Miguel, vai estudar", e ele não queria. Ele achava que tinha somente que trabalhar. Mas aí o que acontece? Depois que ele veio para São Paulo, entrou na EDUCAFRO e abriu a mente dele. [...] Faz tempo [que o meu pai entrou na EDUCAFRO]. [...] Isso abriu a mente dele... Não só na EDUCAFRO, mas terminar os estudos, principalmente, entendeu? Ele viu que, para poder ter um emprego melhor, precisa dos estudos. Então, a partir do momento que ele foi vendo isso, ele foi aprendendo, a vida mesmo ensina que, para você vencer essas dificuldades, precisa ter estudo. Por isso que eu acho que abriu a mente dele, ele teve uma nova visão sobre a vida.
\end{abstract}

Embora o estímulo à escolarização e seu acompanhamento tenham sido exercidos majoritariamente pelas mães, o que também aconteceu no grupo A, no grupo B, a mediação de leitura foi exercida por um número maior de membros da família. A existência de mais leitores no âmbito familiar propiciou muito mais oportunidades de interlocução sobre as leituras realizadas por leitores muito mais experientes, interlocução essa que o sujeito apenas presenciou ou da qual ele participou.

Dentre os momentos de discussão sobre leituras que o sujeito testemunhou, podemos citar as conversas do pai e da avó com outros adultos leitores no caso de Álvares e os cultos e as interpretações da Bíblia no de Taiko:

\footnotetext{
Álvares: Ele era sério comigo. Eu tinha contato com meu pai pelas conversas que ele tinha com as pessoas, ele ficava conversando e eu ficava escutando. Eu não tinha muito contato com meu pai. Ele não gostava muito de criança. [...] Até folclore, essas coisas de Mula sem cabeça, Lobisomem e todas essas histórias imaginárias da área folclórica eu peguei oralmente e antes de ser alfabetizado também. Me recordo de muitas coisas que acho que também foi instrumento para depois eu me adaptar assim... Muitas coisas que eu buscava na oralidade e depois na escrita... [A minha avó era] autodidata e [tinha] contato com pessoas que tinham leituras. Então, ela sempre conversava e de novo a oralidade e mais oralidade e às vezes as pessoas tinham com minha avó esse contato. Eles liam e tinha uma troca, né. Às vezes, a pessoa dava livro para ela e ela dizia: "Ah, você quer ler?" Tô querendo dizer que tinha isso, né, troca de livros, né. Hoje em dia é mais difícil.
} 
Taiko: Ele [o meu pai] lia [a Bíblia] em silêncio e às vezes ele lia em voz alta, lia um versículo para a gente e eu entendia. Até hoje, eu entendo. Tem pessoas que não têm facilidade para entender o que está escrito na Bíblia, tipo uma palavra, você abre a palavra, abre a Bíblia no meio e pede para Deus falar com você. Aí, naquilo que cair, é o que Deus quer falar com você. Aí você tem que saber interpretar a história, tudo, mas tem gente que não sabe interpretar, é mais sabedoria de Deus, com a Bíblia, é mais sabedoria, não vem assim dos homens. Com a Bíblia, é diferente dos livros normais... É mais espiritual, entendeu? É mais fascinante ainda porque ela conta a vida dos homens. [...] Tem tudo, porque ela conta o começo, o meio e o fim, ela conta o que vai acontecer, o que já aconteceu e o que está acontecendo no momento. A palavra é a boca de Deus, entendeu? [...] Acho que [eu aprendi a interpretar os versículos da Bíblia] vendo as próprias pessoas das igrejas, meu pai e minha mãe explicando. Aí eu fui pegando a técnica e fui colocando em prática.

[Eu ia à igreja] todos os dias. Até hoje, têm cultos todos os dias. [Os cultos são] à noite, segundas, quartas e sextas consagrações, que é das oito às dez da manhã e no sábado também tem consagração. [Na consagração] lê e interpreta [trechos da Bíblia]. Aí há louvores, cânticos ao espírito santo... [Quando eu era pequena] na minha igreja, tinha escola dominical. Aí, eu participava. E quando não tinha, eu sentava e prestava atenção ao culto e entendia o que o pastor queria dizer. Tem crianças que pensam um pouco igual gente grande, tem problemas, mesmo que ela não fale, mas ela tem os probleminhas dela e, quando a pessoa falando lá do púlpito, ela recebe aquilo que ele está falando e entrega ali mesmo seus problemas a Deus, e Deus resolve, que era o que eu fazia quando eu era criança. [...]

[Quando eu nasci, meus pais já tinham o hábito de ir à igreja] e de ler a Bíblia. Os dois, toda a família.

Como exemplos de interlocução sobre leituras das quais o sujeito participou, estiveram: as conversas da avó e das tias com Álvares; e os diálogos da mãe, tia, prima e irmã com Beatriz; as interpretações da Bíblia na casa de Taiko; as discussões sobre a cartilha dos irmãos com Zapata e as conversas deste com seu irmão rapper. Nessas oportunidades, houve disseminação dos conhecimentos pelos leitores mais experientes e resolução de eventuais problemas de compreensão de texto. Houve também recomendação de leituras e, obviamente, a difusão das concepções de leitura presentes na família.

\begin{abstract}
Álvares: Aí ela [a minha avó] vinha e me mostrava as plantas e lia livros sobre As Plantas Curam,o que cada planta faz e pelo folclore também. Quando você lê um livro, você lê o nome de uma planta que você nunca viu, que acontece, né? Quando você pega um livro do Graciliano Ramos ou Grande Sertão Veredas, do Guimarães Rosa, Os Sertões, do Euclides da Cunha, tem toda... umas plantas e que a maioria a gente não conhece. E era legal porque minha avó me levava para ver mesmo, pegava... E até quando eu lia, eu significava diferente porque eu tinha visto aquela planta.

$[\ldots]$

Então, minha tia era hippie e eu ajudava ela a fazer... E ela tinha acesso a uma literatura do estilo on the road, que era o pé na estada. Ela tinha toda aquela contra-cultura. Então, eu tinha acesso a toda uma gama de outras leituras sobre a realidade porque a minha tia tinha viajado o Brasil todo, vendendo artesanato. [...] Então, eu tive um contato, eu ajudava ela a ficar fazendo artesanato. E eu tinha um contato com a leitura através da oralidade que às vezes ela falava sobre os livros e eu não tinha lido os livros, mas eu conhecia muitos livros de ouvir falar sobre os livros. E às vezes é até melhor porque quando eu tinha acesso ao conteúdo deles antes de lê-los, como se fossem mediadores do conhecimento. E aí quando eu lia, eu lia já... minha leitura já vinha voltada para alguma característica que, se eu tivesse lido sozinho, eu não teria descoberto sozinho porque o conhecimento é historicamente construído e acumulado, socialmente construído e acumulado. A sociedade é um legado coletivo, não é individual. É um legado coletivo.
\end{abstract}

Beatriz: $[\mathrm{Eu}]$ ia [sempre na tia Ruth]. Depois que eu mudei pra Poá, eu ia todo final de semana. Depois que minha mãe faleceu. Eu tinha 15 anos, aí eu ia todo final de semana, ia de sexta e ficava até domingo lá na casa. [...] Eu ficava com nossos primos, que já não mora mais todo mundo no mesmo quintal, mas mora perto. Mas a minha tia continua morando lá na mesma casa onde a gente morou e aí todo final de semana a gente ia para lá. E a gente ficava sempre na casa dela. E ela sempre tinha um livro novo para 
dar pra gente ler. [...] A gente lia bastante livro, ela já tinha computador e a gente mexia um pouquinho no computador e ficava com os meus primos mesmo. A gente saía um pouquinho com eles, mas mais eu ficava lá dentro da casa da minha tia mesmo. [...] A minha prima Raquel [...] gosta de ler. [...] Porque a gente pegava os livros emprestado da mãe dela e ela ligava aqui, perguntando: "Você tá com tal livro?", "Você tá com tal livro?" A gente falava: "Estou." Então, ela falava: "Então, traz que eu quero ler também". E a gente comentava se ela tinha lido o livro e ela comentava do livro com a gente. Então, deduzo eu que ela também gostava de ler tanto quanto nós.

Nas famílias de 2 sujeitos - Álvares e Zapata - foi fortemente difundida a concepção

de leitura para emancipação do ser humano e para a transformação da realidade. $\mathrm{Na}$

família de Álvares, tal difusão foi feita pela avó, pai e tias e, na de Zapata, pelo irmão:

\begin{abstract}
Álvares: Que é a regra geralmente. E a família cumpre o papel dela, a escola... com a difusão da ideologia dominante, os aparelhos de informação, a mídia... E é interessante por eu ter esse viés desde pequeno que eu comecei a perceber que a mídia falava... ou a leitura da mídia, ou a Folha de São Paulo, o Jornal da... Eu não acreditava mais nos jornais, na revista Veja, Isto é, porque essas revistas estavam representando as pessoas que estavam contra mim. [Eu comecei a ter essa consciência] antes dos onze anos. [...] Por causa da minha avó. [...] A minha avó ela tinha acesso, ela sabia a questão das classes sociais, de como funcionavam as coisas e ela sempre ficava martelando alguma coisa e ficava jogando algumas coisas para a gente, na questão de não acreditar na mídia, na questão de qual a finalidade do ser humano, pra que nós estamos aqui, qual a nossa finalidade individual, social e acabou me mostrando esse viés e acabou me fazendo mais - que eu sempre fui considerado sensível na família - e a sensibilidade fez eu, eu... Eu me sentia mal de ver um documentário da Somália e eu chorava. Eu comia e não entendia porque umas pessoas comiam e outras não comiam. Por que essas pessoas não comem? Eu queria entender e fazer algumas coisas para aquelas pessoas comerem.

$[\ldots]$

[Lá na casa da minha avó] tinha bastantes livros, de todas as gamas, de jogos, esotéricos... Minha família tem todo esse lado também de esotérico, pirâmides, maçonaria, essas coisas... Como é que chama? Grupos fechados Rosa Cruz, não sei o quê. E ao mesmo tempo que também dentro dessas confrarias, eles trabalham com a leitura e o estudo de coisas, de umas verdades que eles acreditam para poder melhorar a sociedade. Até o marxismo mesmo, se você ver no fundo, no fundo, o marxismo vem numa tendência literária, porque lá em Isaías fala assim: "Acabaram-se as guerras e os arados". Naquela época, as pás se chamavam arados. Então, a gente tem numa tendência de querer um mundo melhor, de querer transformar a realidade, de não ser um ser humano só para nascer, crescer e morrer.
\end{abstract}

Zapata: [Eu comecei a ler Marx] um pouco de influência [dos meus irmãos] e um pouco também da época que começou a despertar a questão da indignação. Não só com os irmãos, mas também com outras pessoas, como o Vagner. Ele era bem chegado com o Fernando e eles tinham um grupo de rap.

\title{
Na família de 3 sujeitos - Beatriz, Zapata e Álvares -, houve disseminação da
}

concepção de leitura como fonte de lazer/prazer. Ela foi difundida por todos os modelos de leitores - à exceção da mãe de Álvares -, e em especial pela mãe de Beatriz:

Beatriz: Com certeza [antes de dormir, a gente ia lá na cama da minha mãe pra ver ela ler]. É porque era pouco tempo que a gente tinha com ela. O tempo que ela tinha, ela gostava de ler, então, a gente sempre ficava bem pertinho dela vendo ela ler. Ela lia, falava para gente o que ela estava lendo, explicava muitas vezes também. [Ela] era bem mãezona. Meu pai que é distante, mas minha mãe não era não. [Ela lia pra gente e] tinha [pipoca e tudo]. Às vezes, a gente sentava no sofá mesmo. Tinha bolinho de chuva. Ela fazia bolinho de chuva e chá [risos]. [...] E a gente ficava na sala e ela ficava lendo e a gente enrolada no cobertor, sentada na sala, e ficava lendo, comendo bolinho de chuva e tomando chá [risos]. Com certeza [ler é hoje uma forma de lembrar a mãe]. Vou ler um pouco para matar a saudade dela. 
As atividades de leitura nas famílias de Beatriz e Zapata têm em comum também o importante papel exercido pelos irmãos. Além de colaborarem para a escolarização sendo exemplos de bons alunos e ensinando os mais novos antes mesmo que estes ingressassem na escola, os irmãos mais velhos foram modelos de leitores e estimularam a leitura, envolvendo os mais novos em práticas pautadas pela afetividade e pelo prazer:

Zapata: [Os meus irmãos foram bons alunos] sempre, tirando o mais velho, que não sei se ele era bom aluno ou mau aluno, mas ele parou na quinta série porque numa família pobre, o mais velho é que sofre mais. Vai trabalhar e tal.

[...]

A gente estudava tudo. Assim, hoje não, mas na época era bom tudo. Tanto é que, se você pegar meus irmãos mais velhos, o William que estudou até a sexta, ele não participa de nada, agora o Fernando mesmo e até o AK47, que veio depois, eles são bons em tudo. Quer dizer, eles sabem pelo menos o básico, matemática, biologia. Eu sempre estudei tudo e até que era muito fácil porque era decoreba.

[...]

Meus irmãos, o Edney e o William, ficava naquela cartilha lá discutindo os textos, lendo. Não discutindo como hoje, pedindo para eu escrever, mas a gente gostava muito da cartilha. Eu tenho que ler porque eu tenho quase certeza que eu não daria para o meu aluno, nem ferrando, mas a gente gostava muito, Caminho Suave. Tinha uns textos muito bacanas [na cartilha]. Eu lembro que o que a gente ficou mais assim foi "O Quintal da Bicharada". Tinha o um e o dois e tinha quintal, tinha vários bichos e sempre aquela imitação da fábula, do lobo que ia pegar os bichos, não sei o quê. Discutia assim esses textos, as narrativas curtas. Eu acho que é importante para a formação do leitor, o problema é como a escola faz. [...] Depois esses textos é para que, era para incentivar a formação de leitores. E, por exemplo, no nosso caso, foi importante porque a gente já tinha alguma coisa aguçada para isso.

$[\ldots]$

Pesquisadora: Você acha que esses textos incentivavam vocês que já tinham essa coisa aguçada porque tinham essa prática de leitura dento de casa?

Zapata: E eu ainda estou falando de coisa de nove, dez anos. A gente lia, brincava. Discutia assim, né. [...] A gente ficava lendo e conversando sobre o texto, lia bastante, era isso, né.

$[\ldots]$

O meu irmão, o William, inclusive hoje ele é Testemunha de Jeová. O pessoal passava na porta com aquela revista Sentinela, sabe Sentinela? E ele era pior do que eu, porque eu só vivia na rua. [E,] nossa, ele lia o dia todo. Gibi, ele é o que mais gostava de gibi e começou a adquirir essas revistinha aí, até que hoje ele foi para lá.

Beatriz: Porque a gente primeiro conversava com a nossa mãe: "Mãe, fala pra Flávia levar a gente pra biblioteca". Aí minha mãe pedia e ela levava a gente na biblioteca da Vila Formosa, que era perto da nossa casa, e aí a gente passava a tarde lá. Se não pudesse levar pra casa, a gente ficava a tarde lá lendo. E a gente pegava mais livro infantil porque a gente era muito pequenininha naquela época. Mas eu gostava muito de ir na biblioteca de lá. [...] Ah, lá era muito legal. Tinha muito livro e a gente ficava muito eufórica para ler lá. Por isso que eu gostava muito de ir naquela biblioteca. E a companhia das minhas irmãs me fazia sentir bem. Porque a gente, eu e a Paula, a gente sempre ficou junto, mas a Flávia e a Andréa a gente não ficava. A gente não fica muito junto. Eu gostava muito de ir na biblioteca com elas, eu me sentia bem na biblioteca, porque a gente só lia com as minhas irmãs na biblioteca. Na biblioteca da Vila Formosa.

Dentre os 3 sujeitos em cujas famílias se difundiu a concepção de leitura por prazer/lazer - Álvares, Beatriz e Zapata -, Álvares foi o único que adjetivou a palavra prazer, referindo-se a uma concepção de leitura por prazer estético:

Álvares: Acho que depende da leitura: se a leitura era com o objetivo de ganhar dinheiro, era uma coisa. Agora, leitura com prazer de ler e para ter conhecimento que não vai ajudar em algo, é outra. Tanto que 
minha mãe era pragmática. E as outras pessoas [minha avó e minhas tias paternas] dava para perceber que elas gostavam pelo prazer estético, sem finalidade, só pelo prazer estético.

Na família de Taiko, tanto a mãe quanto o pai verbalizaram a concepção de leitura para acessar a sabedoria Divina e foram modelos de leitores da Bíblia, cuja leitura Taiko foi incentivada a fazer desde muito jovem:

Taiko: [Eu comecei a gostar de ler] desde criancinha, porque eu nasci num berço evangélico... [Nascer num berço evangélico] é você nascer, seus pais já serem cristãos e você já nasce eles sendo cristãos, continua sempre evangélico, na religiosidade e tal. Aí, eu tinha sempre o desejo de ler a Bíblia. Então, eu me esforçava para aprender a ler somente para ler a Bíblia. Entendeu?

Nas famílias de todos os 4 sujeitos - Álvares, Beatriz, Taiko e Zapata - em que houve estímulo à leitura, isso parece ter acontecido de modo agradável, "sem pressão", ou seja, sem uma imposição ao sujeito da prática de leitura, sem um caráter de obrigatoriedade, como o trecho da fala de Zapata bem ilustra:

Zapata: Eu nunca gostei de gibi. Agora, tinha muito gibi, muita coisa de ler. Meu pai mesmo, apesar que, nesse processo, eu já não estava com meu pai, mas meu pai mesmo lia muito aquelas porcarias daqueles livros que vende em banca. Bang bang e tal. Então, acho que esse era o contato. Era uma coisa quase cultural... [O meu pai] lia alguns [livros], mas ele não era o responsável não, eram mais os irmãos. Tinha [bastantes livros dos meus irmãos em casa]... Era mais o [meu irmão] Fernando [que me alfabetizou e me ensinou a fazer continhas]. O Fernando sempre foi um cara assim, sempre foi duas moedas. Sempre foi uma moeda, duas moedas não pode, chato, mas legal. Eu lembro, mas o processo não sei dizer. Não era aquela coisa assim... Ah, você tem que estudar. Era uma coisa bem natural nossa e também a gente lia muito. [...] Como eu falei, o Fernando que é o mais velho dos que participam, tem o Nino que é mais velho que o Fernando, [e a mediação de leitura] foi uma coisa "natural", mas nunca foi de influenciar e com nossos outro irmãos a gente quer que seja assim também, porque se meu irmão quisesse ser um rapper ou um jogador de basquete ou se não quiser ser porra nenhuma, isso é um problema deles. A nossa influência nunca foi assim, o Fernando nunca chegou assim e..."Você tem que ler, tem que ler".

Dois pesquisados - Álvares e Beatriz - foram constantemente encorajados a ler gibis e literatura infantil e infanto-juvenil por suas famílias, que lhes franquearam o acesso a esses materiais. Ambos também foram estimulados pela família a visitar bibliotecas públicas desde a infância:

\footnotetext{
Álvares: E pela minha família, eu tive mais acesso a algumas literaturas, algumas pessoas me davam isso, minhas tias... [Elas eram] irmãs do meu pai. E elas eram pessoas que já tinham feito universidade e tal.

[...] Eu lembro muito do Asterix, Asterix grande, que eles escreviam a nanquim. Eu lembro que ele falava: "Bebemos tantos litros de cerveja e tantos litros de nanquim gastamos no Império Romano". [...] Lá no Jabaquara. No Jabaquara tinha uma biblioteca que eu não me recordo o nome, que eu morei no Jabaquara até os... mais ou menos até os doze anos, no Jabaquara, até os catorze anos eu morei no Jabaquara, ali perto do metrô Jabaquara, na zona sul. Então, lá tinha uma biblioteca próxima, era bem próxima... Era [uma biblioteca pública]. Era bem melhor, era até perto do Metrô, de fácil acesso, biblioteca enorme. Eu tinha uns contatos lá, então, tipo Asterix eu lia, só podia ler Asterix, para fazer trabalho de escola, eu ia pra ler, que falava do império romano, fala sobre... Que aí também...
} 
Beatriz: [Eu me lembro da minha mãe lendo] bastante... Ela lia de manhã antes de sair para trabalhar, quando ela chegava em casa de noite, antes de dormir ela lia, depois que ela fazia as coisas, ela lia um pouco também antes de dormir. Na hora do almoço no serviço, que eu também ia trabalhar bastante com minha mãe, ela lia também. [Na hora do almoço] ela levava a gente na biblioteca e aí a gente escolhia um livro para nós e aí ela escolhia um livro para ela e aí a gente ia lendo assim na hora do almoço dela. [...] Quando eu era menor, minha mãe comprava livro e deixava no serviço dela para gente ler lá. Depois que a gente ficou maior, aí ela levava a gente na biblioteca com ela, para gente escolher um livro para nós e ela escolher um livro para ela. [...] Das vezes que eu não ia, eu pedia para minha mãe trazer. Eu ficava em casa e eu falava um livro assim: "Mãe, eu quero mistério, eu quero ler mistério." Aí ela ia lá, escolhia e trazia.

[...]

Eu gostava muito de ir na biblioteca. A gente só podia ir no final de semana com minha irmã, porque ela estudava em horário diferente que o nosso. [...] Porque a gente, primeiro, conversava com a nossa mãe: "Mãe, fala pra Flávia levar a gente pra biblioteca". Aí, minha mãe pedia e ela levava a gente na biblioteca da Vila Formosa, que era perto da nossa casa, e aí a gente passava a tarde lá.

A interação dos 4 sujeitos nas famílias dos quais havia práticas de leitura - Álvares, Beatriz, Taiko e Zapata - com leitores mais experientes foi muito freqüente e prolongada. $\mathrm{O}$ contato de Álvares com o pai foi diário e com as avós e tias se deu também diariamente nas férias de verão e inverno, quando o sujeito viajava para a casa delas, durante a infância e adolescência. Beatriz teve contato diário com a mãe, a irmã e a tia até os 15 anos, quando do falecimento da mãe. A partir de então, a interação com a tia passou a ser semanal (de sexta a domingo). A convivência de Taiko com os pais e de Zapata com os irmãos foi diária. Ela estendeu-se por toda a infância e adolescência no caso de Taiko e avançou até a idade adulta no de Zapata.

Interessante ressaltar que alguns modelos de leitores foram muito importantes para os sujeitos, mesmo que não estivessem fisicamente presentes. Trata-se, por exemplo, do caso do pai de Álvares. O sujeito descreveu o relacionamento do pai com ele como frio e distante. Depois, o pai veio a falecer quando Álvares tinha 18 anos. No entanto, o sujeito, que sempre desejara imitar o extraordinário desempenho do pai como estudante e como leitor, continuou a esforçar-se para igualar-se ao pai mesmo depois do falecimento deste. Tal desejo pode ter sido ainda mais fortalecido pelo fato de o sujeito ter o mesmo nome do avô e do pai, no que denota uma certa ênfase na continuidade das características da família. E, ao referir-se ao lado paterno da família, Álvares enfatizou a tradição muito letrada de seus membros, que remontava ao escritor Gregório de Matos, tio-avô da avó do sujeito.

No caso de Beatriz, aparentemente, ao falecimento muito repentino da mãe leitora quando as filhas gêmeas tinham apenas 15 anos, seguiu-se um desenvolvimento ainda maior de leituras. De acordo com elas, ler tornou-se, para além de uma prática por meio da qual se obtinha conhecimento ou prazer/lazer, uma forma de lembrar os momentos de afeto com a mãe, fazendo aquilo de que ela mais gostava. 
No grupo B de leitores, não foi possível identificar como a mediação de leitura no âmbito da família teria acontecido no caso de um entrevistado - Malik. De fato, o sujeito asseverou que não havia práticas de leitura em sua casa e que nunca foi incentivado a ler ou a estudar. Portanto, aparentemente, não teria sido verbalizada no âmbito familiar nem a concepção de leitura mais comum - como fator de emancipação econômica - que está fortemente vinculada à escolarização. No entanto, Malik relatou acreditar que lhe cabia o dever de ter excelente aproveitamento escolar, já que seus pais estavam lutando para manter a família.

Depreende-se dos depoimentos de 4 dos 5 sujeitos do grupo B que houve, em suas famílias, mais práticas de leitura seja porque houve um número maior de leitores seja porque eles liam com maior freqüência. Além disso, havia nessas famílias uma maior diversidade de materiais de leitura, dentre os quais o livro era o mais comum. Apesar de, a exemplo do que aconteceu no grupo $\mathrm{A}$, ter havido forte estímulo à escolarização, o estímulo à leitura não foi tão estritamente ligado ao projeto de escolarização, e tampouco incentivado exclusivamente pelas mães: a mediação de leitura foi exercida por um número maior de membros da família, que difundiram concepções de leitura também mais diversas. A existência de mais leitores na família propiciou que o sujeito assistisse mais interlocuções sobre leituras que ele próprio ainda não havia realizado.

\subsubsection{A mediação de leitura pela família: comparando os grupos A e B}

Os leitores dos grupos A e B têm muito em comum, incluindo o forte estímulo dado à escolarização da maior parte de seus componentes. Mas há também diferenças importantes entre eles no que diz respeito à contribuição de suas famílias para sua constituição como leitores.

Havia práticas de leitura na família de 5 dos 8 sujeitos do grupo A de leitores e nas famílias de 4 dos 5 pesquisados do grupo B. Nas famílias em que houve práticas de leitura, elas foram desenvolvidas por um maior número de pessoas no grupo B - 16 leitores para 4 sujeitos - do que no grupo A - 12 leitores para 5 sujeitos.

A frequiência das práticas de leitura nas famílias do grupo B foi mais elevada que aquela do grupo A de sujeitos. No grupo A, 5 leitores - as mães e pais de Frida e Marley e o pai de Paula - liam ocasionalmente. Já no grupo B, 11 dos 12 leitores parecem ter lido diariamente e várias vezes ao dia. 
Outra diferença entre o grupo A e o grupo B diz respeito aos materiais que os leitores utilizavam no ambiente doméstico. No grupo A, os pesquisados aludiram a: revistas (3 leitores), jornais (3), gibis (2), livros (2) - inclusive aqueles comprados em bancas, como histórias de faroeste - e a Bíblia (1). Já no grupo B, os sujeitos citaram: livros (8 leitores), gibis (4), revistas (3), jornais (3) e a Bíblia (2). Aparentemente, havia no grupo B uma quantidade maior de leitores lendo livros ${ }^{83}$.

Além de haver mais praticantes de leitura na família dos sujeitos do grupo B e um maior número de leitores de livros, a média de escolaridade das mães e pais dos sujeitos era mais elevada, o que pode ter contribuído para uma mediação de leitura mais qualificada e talvez também para a difusão de concepções de leitura para além daquela estritamente vinculada à escolarização.

Para uma melhor visualização, disponibilizo a seguir um quadro das concepções de leitura mais presentes nas famílias, segundo se pôde depreender dos depoimentos dos sujeitos dos grupos A e B de leitores:

Concepção do ato de leitura

Leitura como fator de emancipação econômica e ascensão social

\section{Leitura por lazer/prazer}

Leitura para obtenção de conhecimento

Leitura para a emancipação do ser humano e transformação da realidade

Leitura para acessar a sabedoria Divina

\section{Famílias do \\ grupo $A$ (8 sujeitos)}

7

2

2

\begin{tabular}{|l|l|}
\hline 2 \\
\hline 2 \\
\hline 2 \\
\hline
\end{tabular}

1

No grupo B, pareceu haver uma distribuição mais homogênea das concepções dos atos de leitura. Talvez o fato de a leitura não ter estado tão estritamente vinculada apenas à necessidade de escolarização para ascensão social tenha feito com que ler fosse visto por mais pessoas não como uma obrigação, mas como algo prazeroso.

\footnotetext{
${ }^{83}$ Polêmicas à parte sobre a arbitrariedade na legitimidade dos portadores, é inegável que a leitura de livros parece ser mais complexa e demandar maior disposição por parte do leitor do que a de textos de extensão menor presentes em gibis e revistas, por exemplo. Não por acaso, a pesquisa Retratos de Leitura no Brasil, à qual me referi anteriormente, utilizou como critério para a definição de leitor aquele sujeito que declarou ter lido ao menos um livro nos últimos 3 meses.
} 
Para 4 sujeitos do grupo B - Álvares, Beatriz, Taiko e Zapata -, a família teve tanta relevância para sua constituição como leitores que ouso supor que eles provavelmente teriam se tornado leitores mesmo que não tivessem se mantido na escola. Para esses sujeitos, o papel da escola foi menos importante que o da família.

Na comparação entre os dois grupos, o sujeito Malik, pertencente ao grupo B, parece constituir sempre exceção quanto ao que se afirma a respeito dos sujeitos de seu grupo. De fato, ao contrário do que aconteceu com os outros membros de seu grupo, Malik não encontrou em casa nem praticantes de leitura nem alguém que o incentivasse a estudar e a ler. Também Paula, alocada no grupo A, e irmã gêmea de Beatriz, parece ter uma história muito dissonante daquela de outros membros de seu grupo, o que levaria a crer que deveria integrar o grupo B de leitores.

Os casos desses dois sujeitos - que poderiam ser vistos apenas como inexplicáveis ou até como uma gritante falha na análise - talvez possam ser iluminados pelo estudo do tipo de relação que ambos os leitores desenvolveram desde muito cedo com a escola e o saber. Isso será feito no tópico a seguir.

\subsection{A mediação de leitura no âmbito da escola}

A partir dos dados apresentados a seguir, procuro responder qual foi a mediação de leitura exercida pela escola, ou seja, se havia práticas de leitura nesse ambiente para além daquelas estritamente vinculadas à alfabetização ou ao cumprimento de tarefas escolares, qual o tipo de material a que o sujeito tinha acesso na escola, quais eram as concepções de leitura, quem fazia a mediação da leitura, como e com que freqüência ela era feita, qual era mediação do professor de Língua Portuguesa, se outras pessoas faziam essa mediação (como, por exemplo, outros professores, alunos de outras séries) e, mais especificamente, qual foi a mediação exercida pelo livro didático de Língua Portuguesa.

$\mathrm{Na}$ lista de objetivos da presente pesquisa não havia nenhuma questão sobre os âmbitos de escolarização para além do Ensino Médio, tais como cursos pré-vestibulares e cursos de capacitação diversos - que decidimos chamar genericamente "Outras modalidades de escolarização" (OME) - ou mesmo cursos de graduação. Porém, eles emergiram dos depoimentos como âmbitos importantes para a constituição dos sujeitos, pois fizeram um trabalho de mediação de leitura que a escola básica não havia realizado a contento.

Para uma melhor visualização dos dados, novamente disponibilizo quadros sinópticos. 
Neles, recorremos freqüentemente a abreviações, as quais listo a seguir:

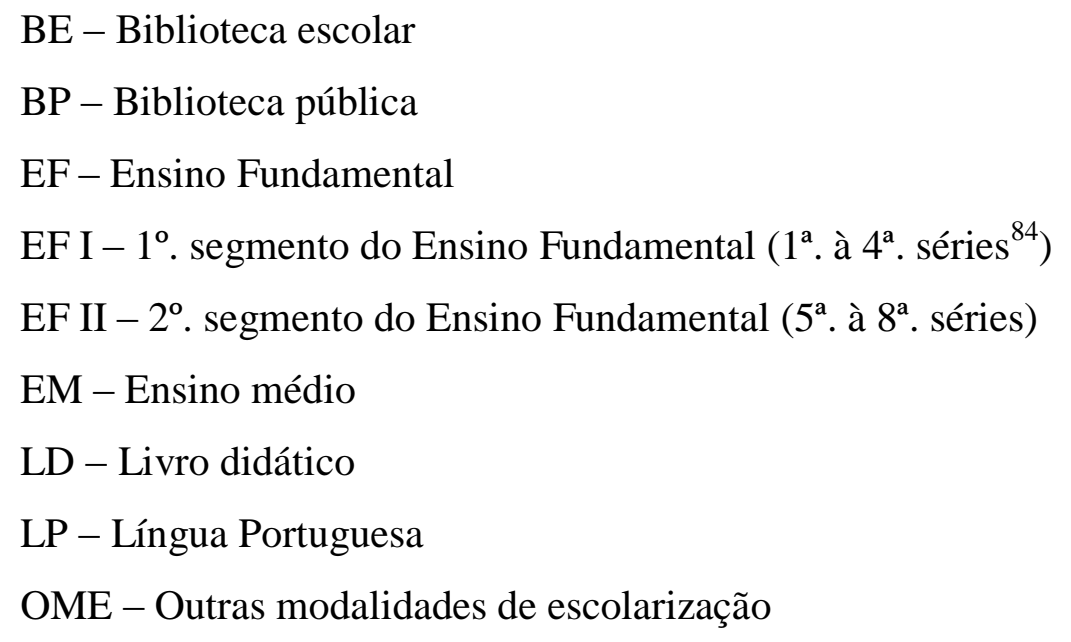

Quando eventualmente nada tiver sido escrito numa determinada célula do quadro, deve-se compreender que não foi possível depreender do depoimento aquele dado. Foi o que aconteceu, por exemplo, com os sujeitos AK47 e Dandara, cujas práticas de leitura promovidas pela escola foram tão raras e precárias que não identifiquei concepções dos atos de leitura naquele ambiente.

\footnotetext{
${ }^{84}$ Embora recentemente a escolarização básica tenha passado a ser dividida em 9 anos e não em 8 séries, mantive em meu texto o uso do termo série para assegurar certa uniformidade com as falas dos sujeitos e, assim, facilitar a compreensão da análise.
} 


\section{MEDIAÇÃO DA LEITURA NA ESCOLA - GRUPO A (Leitores)}

\begin{tabular}{|c|c|c|c|c|c|c|}
\hline Sujeito & $\begin{array}{l}\text { Havia práticas de leitura } \\
\text { na escola?Qual a } \\
\text { freqüiência dessas } \\
\text { práticas? }\end{array}$ & $\begin{array}{l}\text { Quais as } \\
\text { concepções dos atos } \\
\text { de leitura dentro da } \\
\text { escola? }\end{array}$ & $\begin{array}{l}\text { Quem fazia a mediação de leitura? } \\
\text { Como e com que frequiência? } \\
\text { Qual foi a mediação exercida pelo prof. de Língua } \\
\text { Portuguesa? }\end{array}$ & $\begin{array}{l}\text { Outras pessoas fizeram } \\
\text { essa mediação, como, por } \\
\text { exemplo, outros } \\
\text { professores, alunos de } \\
\text { outras séries etc? }\end{array}$ & $\begin{array}{l}\text { Qual foi a } \\
\text { mediação } \\
\text { exercida pelo } \\
\text { livro didático } \\
\text { de LP? }\end{array}$ & $\begin{array}{l}\text { Para além da } \\
\text { escolarização } \\
\text { básica: } \text { OME e } \\
\text { universidade. }\end{array}$ \\
\hline AK47 & $\begin{array}{l}\text { Não. Exceção: } \frac{6^{a} \text {. série: }}{\text { acesso à BE, mas sem }} \\
\text { mediação pela profa. }\end{array}$ & & $\begin{array}{l}\text { Parca mediação: apenas por profs. do EF e de LP. } \\
\text { Profas da } 1^{\circ} \text {. à } 5^{\text {a }} \text {. série: rigidez, repressão, seletividade. } \\
\text { Barreiras à escolarização. Parca mediação da leitura. } \\
\text { Profa. de LP na } 6^{\text {a }} \text {. série: não mediação na BE. } \\
\text { Profs de LP do EM: apresentação mal-sucedida de } \\
\text { literatura de modo geral e das obras clássicas de literatura } \\
\text { brasileira. Linguagem difícil. }\end{array}$ & Não. & $\begin{array}{l}\text { Negativa. Dis- } \\
\text { tância entre } \\
\text { textos e reali- } \\
\text { dade. Não estí- } \\
\text { mulo à busca } \\
\text { de conheci- } \\
\text { mento. Difi- } \\
\text { culdades com } \\
\text { linguagem. }\end{array}$ & $\begin{array}{l}\text { Profa. da } \\
\text { universidade: } \\
\text { auxílio para } \\
\text { desenvolver } \\
\text { habilidades } \\
\text { leitoras, } \\
\text { empréstimos de } \\
\text { material } \\
\text { impresso. }\end{array}$ \\
\hline ANDRÉ & $\begin{array}{l}\text { Sim no EF II e EM. } \\
\text { BP para trabalhos } \\
\text { escolares. Ocasional. }\end{array}$ & $\begin{array}{l}\text { Leitura para a } \\
\text { escolarização. } \\
\text { Leitura como fonte } \\
\text { de prazer. } \\
\text { Leitura por } \\
\text { obrigação. }\end{array}$ & $\begin{array}{l}\text { Profa. de LP determinada e comprometida. } \\
\text { Profa. de LP no EFII: } \\
\text { Leitura de literatura juvenil em voz alta, fornecimento de } \\
\text { textos, empréstimo de livros. } \\
\text { Mesma profa. de LP no EM: } \\
\text { Difusão da concepção de leitura por obrigação. Mediação } \\
\text { mal-sucedida de literatura brasileira, sua temática e } \\
\text { linguagem. }\end{array}$ & $\begin{array}{l}\text { Profa. ciências EFII: } \\
\text { incentivo à melhora de } \\
\text { aproveitamento, } \\
\text { afetividade. } \\
2 \text { colegas: interlocução } \\
\text { sobre leituras e } \\
\text { fornecimento de livros. } \\
\text { Colegas no EM: } \\
\text { popularidade devido a seu } \\
\text { aproveitamento e leituras. }\end{array}$ & $\begin{array}{l}\text { Pouco } \\
\text { significativa. } \\
\text { Não despertou } \\
\text { vontade de ler } \\
\text { literatura } \\
\text { brasileira. }\end{array}$ & \\
\hline DANDARA & $\begin{array}{l}\text { Pouquíssimas. Idas à BE } \\
\text { (raríssimas) só com o } \\
\text { professor. Parca leitura de } \\
\text { literatura infanto-juvenil. }\end{array}$ & & $\begin{array}{l}\text { Praticamente ninguém. Muito raramente. } \\
\text { Profs. de LP: não incentivo à leitura. Mediação pouco } \\
\text { significativa. }\end{array}$ & Não. & $\begin{array}{l}\text { Pouco } \\
\text { significativa. }\end{array}$ & \\
\hline FRIDA & $\begin{array}{l}1^{\mathrm{a}} \text {. e } 2^{\mathrm{a}} \text {. séries do EF: sim. } \\
\text { Constante. } \\
\text { Ida à BE, com acervo } \\
\text { circulante. } \\
\text { Da } 3^{\mathrm{a}} \text {. série do EF ao final } \\
\text { do EM: não. } \\
\text { BP para trabalhos } \\
\text { escolares. Ocasional. } \\
\text { Afastamento da leitura. }\end{array}$ & $\begin{array}{l}\text { EF: Leitura para a } \\
\text { escolarização, } \\
\text { emancipação } \\
\text { econômica e } \\
\text { ascensão social. } \\
\text { Leitura para } \\
\text { obtenção de } \\
\text { conhecimento. }\end{array}$ & $\begin{array}{l}\text { Profa do pré: Incentivo à leitura e escrita. Afetividade e } \\
\text { comprometimento. } \\
1^{\mathrm{a}} \text {. e } 2^{\mathrm{a}} \text {. Séries do EF: Agradável leitura de literatura } \\
\text { infantil na BE e na sala. Afetividade. } \\
\text { Desenvolvimento de imagem de boa aluna. } \\
\text { Profs de LP: } 3^{\mathrm{a}} \text {. série do EF ao final do EM: mediação } \\
\text { pouco significativa. Falta de comprometimento, não } \\
\text { envolvimento dos alunos. } \\
\text { Profs de LP no EM: não incentivo à leitura. Trabalho } \\
\text { mal-sucedido com literatura brasileira, sua temática e } \\
\text { linguagem. }\end{array}$ & $\begin{array}{l}\text { EF II e EM: sociabilidade } \\
\text { com bons alunos, bem } \\
\text { comportados. }\end{array}$ & $\begin{array}{l}\text { Não } \\
\text { significativa. }\end{array}$ & \\
\hline
\end{tabular}




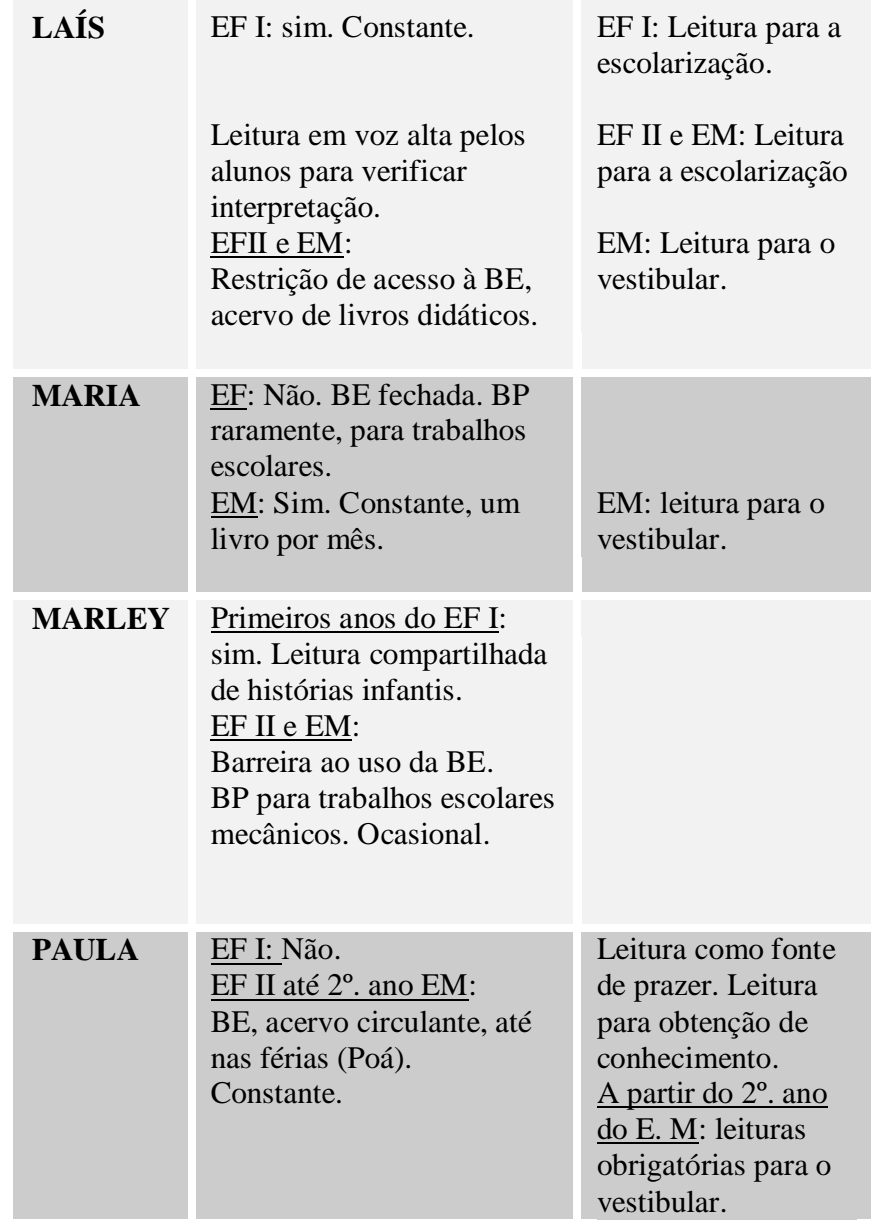

Profa. da $2^{\mathrm{a}}$. série do EF: Orientação à mãe sobre incentivar leitura da Bíblia e gradativamente aumentar complexidade. Afetividade.

Profs. do EF II: Leitura compartilhada de livros de literatura.

Profas. de LP - EM: Leitura de clássicos da literatura Dificuldades com a linguagem e para fazer sínteses. Seminário, debate e montagem de peça. Incentivo à leitura e incentivo à escolarização - participação no ENEM.

EF: Nenhum incentivo à leitura. Aprendizagem pouco significativa.

Profa. de LP no EM: apresentação interessante da

literatura brasileira com vistas ao vestibular. Leitura de um livro por mês.

Profa. da 4a . série: expulsão como barreira à

escolarização: prof. é o inimigo.

Profa. de LP na $7^{\mathrm{a}}$. série: mediação negativa e barreira à escolarização. Sarcasmo quanto ao interesse em ler. Profs. de LP do EF II e do EM: Falta de mediação de

leitura. Aprendizagem pouco significativa, baseada em cópias e memorização. Apresentação mal-sucedida de literatura de modo geral e das obras clássicas, sua temática e linguagem.

Profa. de LP da $5^{\text {a }}$. série do EF ao $1^{\circ}$. ano do EM:

solicitava leituras. Interlocução simétrica com os alunos sobre leituras, aceitando sugestões. Incentivo à leitura $\mathrm{e}$ ao uso do dicionário, elogio à narrativa. Mediação bemsucedida de literatura juvenil. Mediação mal-sucedida de obras clássicas da LB.
Interlocução com colegas bons alunos que liam sobre o que se aprendiam. Incentivo à leitura por

colegas.

\section{Colegas no EM}

Interlocução sobre continuidade de escolarização.

Escola melhor suscitou

maior interesse por estudar e ler.

Colegas nos primeiros anos do EF I: piadas de preconceito racial.

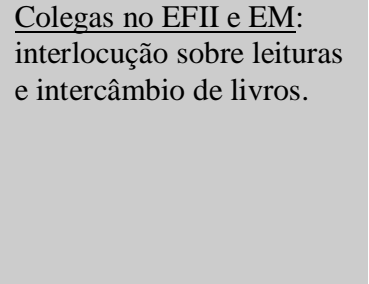

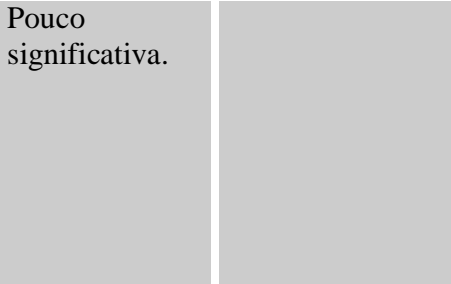

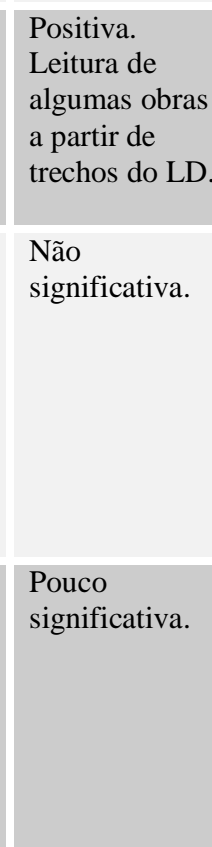

Leitura

umas obras

chos do LD.

(n)
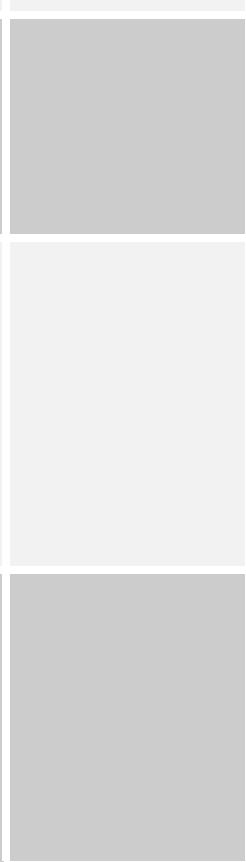

Legenda

BE: Biblioteca escolar

BP: Biblioteca pública

EF: Ensino Fundamental

EF I: $1^{\circ}$. segmento do Ensino Fundamental (1 $1^{\mathrm{a}}$. à $4^{\mathrm{a}}$. séries

EM: Ensino médio

LD: Livro didático

LP: Língua Portuguesa

OME: Outras modalidades de escolarização
EF II: $2^{\circ}$. segmento do Ensino Fundamental ( $5^{\mathrm{a}}$. à $8^{\mathrm{a}}$. séries $)$ 


\section{A MEDIAÇÃO DA LEITURA NA ESCOLA - GRUPO B (Leitores de literatura)}

\begin{tabular}{|c|c|c|c|c|c|c|}
\hline Sujeito & $\begin{array}{l}\text { Havia práticas de leitura } \\
\text { na escola?Qual a } \\
\text { freqüiência dessas } \\
\text { práticas? }\end{array}$ & $\begin{array}{l}\text { Quais as } \\
\text { concepções dos atos } \\
\text { de leitura dentro da } \\
\text { escola? }\end{array}$ & $\begin{array}{l}\text { Quem fazia a mediação de leitura? } \\
\text { Como e com que freqüência? } \\
\text { Qual foi a mediação exercida pelo prof. de Língua } \\
\text { Portuguesa? }\end{array}$ & $\begin{array}{l}\text { Outras pessoas fizeram } \\
\text { essa mediação, como, por } \\
\text { exemplo, outros } \\
\text { professores, alunos de } \\
\text { outras séries etc? }\end{array}$ & $\begin{array}{l}\text { Qual foi a } \\
\text { mediação } \\
\text { exercida pelo } \\
\text { livro didático } \\
\text { de LP? }\end{array}$ & $\begin{array}{l}\text { Para além da } \\
\text { escolarização } \\
\text { básica: OME e } \\
\text { universidade. }\end{array}$ \\
\hline ÁLVARES & $\begin{array}{l}\text { Não. } \\
\text { Rara. }\end{array}$ & $\begin{array}{l}\text { Leitura como algo a } \\
\text { sonegar. }\end{array}$ & $\begin{array}{l}\text { Apenas profs. de LP. } \\
\text { Sem incentivar ou checar leitura. Raramente. } \\
\text { Apresentação de gramática, semântica, métrica, } \\
\text { potencializando prazer estético. }\end{array}$ & $\begin{array}{l}\text { Não. Excluído, vítima de } \\
\text { bullying. }\end{array}$ & $\begin{array}{l}\text { Leitura } \\
\text { antecipada } \\
\text { LDs de séries } \\
\text { posteriores. }\end{array}$ & \\
\hline BEATRIZ & $\begin{array}{l}\text { EF I: não. Sem BE. } \\
\text { EF II ao } 2^{\circ} \text {. ano do EM: } \\
\text { sim. BE com acervo } \\
\text { circulante (Poá). } \\
\text { Constante }\end{array}$ & $\begin{array}{l}\text { Leitura como fonte } \\
\text { de prazer. } \\
\text { Leitura como algo } \\
\text { passível de se } \\
\text { aprender. }\end{array}$ & $\begin{array}{l}\text { Parco incentivo à leitura, com exceção da profa. de LP } \\
5^{\mathrm{a}} \text {. série do EF ao } 2^{\circ} \text {. ano do EM: } \\
\text { Profa. de LP efetiva: Incentivo à leitura e ao uso de } \\
\text { dicionário. Elogio à narrativa. Interlocução informal na } \\
\text { biblioteca sobre as leituras dos alunos e suas opiniões. } \\
\text { Difusão das concepções de leitura por prazer e leitura } \\
\text { como algo passível de se aprender. } \\
\text { 1. ano do EM: Profa. substituta de LP (dois meses). }^{\circ} \text { modelo de leitora de obras clássicas da literatura } \\
\text { brasileira por prazer. Incentivo a tal leitura. Mediação } \\
\text { bem-sucedida dos clássicos, de sua temática e linguagem. } \\
\text { Explicações de vocabulário, questionários, discussões de } \\
\text { interpretação. Leitura compartilhada de trechos de obras. }\end{array}$ & $\begin{array}{l}1^{\circ} \text {. segmento do EF: não. } \\
5^{\mathrm{a}} \text {. série ao } 2^{\circ} \text {. ano: amigos } \\
\text { da mesma idade. } \\
\text { Sociabilidade em torno do } \\
\text { livro }\end{array}$ & $\begin{array}{l}\text { Pouco } \\
\text { significativa. }\end{array}$ & \\
\hline MALIK & $\begin{array}{l}\frac{3^{\mathrm{a}} . \text { à } 5^{\mathrm{a}} \text { série: } \text { sim. Idas à }}{\mathrm{BE}, \text { mas sem mediação. }} \\
\text { Freqüência ignorada. } \\
6^{\mathrm{a} .}, 7^{\mathrm{a}} \text {. e } 8^{\mathrm{a}} \text {. séries: não. } \\
\text { Sem BE. Cópia da lousa } \\
\text { por falta de livros didáti- } \\
\text { cos. Leitura de um livro } \\
\text { por ano. } \\
1^{\circ} \text {. ano do EM: sim } \\
\text { Constante }\end{array}$ & & $\begin{array}{l}\text { Quem: profs. do EF I e profs. de LP } \\
\text { Profa. da } 1^{\mathrm{a}} \text {. série do EF: Elogio e exibição pública da } \\
\text { habilidade de leitura do sujeito. } \\
\text { Profa. da } 2^{\circ} \text {. e } 3^{\circ} \text {. séries do EF: Elogio público e presente } \\
\text { pelo aproveitamento. Incentivos. Desafios (zona de } \\
\text { desenvolvimento proximal). } \\
\text { Professores da escola toda, da } 1^{\mathrm{a}} \text {. à } 5^{\mathrm{a}} \text {. séries do EF: Boa } \\
\text { repercussão do aproveitamento. } \\
\text { Profas. da } 3^{\mathrm{a}} \text {. à } 5^{\mathrm{a}} \text {. série: Idas à BE, mas sem mediação } \\
\text { de leitura. } \\
\text { Profas. de LP da } 5^{\mathrm{a}} .6^{\mathrm{a}}, 7^{\mathrm{a}} \text { e } 8^{\mathrm{a}} \text {. séries: Indicações de } \\
\text { leitura, mas sem possibilidade de acesso. Frustração. } \\
\text { Grande afetividade. } \\
\text { Profa. de LP do } 1^{\circ} \text {. ano do EM: Opções de leitura de } \\
\text { livros com debate. Mediação bem-sucedida dos } \\
\text { clássicos. }\end{array}$ & $\begin{array}{l}\frac{4^{a} . \text { e } 5^{a} \text {. séries do EF, }}{\text { colega com mais acesso }-} \\
\text { Interlocução sobre gibis e } \\
\text { sua linguagem } \\
\frac{5^{\text {a}} \text {. série Profa. de }}{\text { Geografia: Elogio público }} \\
\text { e exibição da habilidade } \\
\text { de escrita do sujeito. } \\
\text { EM: Aluno mais velho na } \\
\text { mesma sala: modelo de } \\
\text { leitor, dono de biblioteca } \\
\text { pessoal. Interlocução } \\
\text { intensa sobre leituras. } \\
\begin{array}{l}\text { Desenvolvimento de } \\
\text { criticidade. }\end{array}\end{array}$ & $\begin{array}{l}\text { 2a. e } 3^{a} \text {. séries } \\
\text { do EF: Fonte } \\
\text { de literatura } \\
\text { infantil, leitura } \\
\text { antecipada. } \\
\text { EM: textos do } \\
\text { livro didático } \\
\text { de geografia. }\end{array}$ & $\begin{array}{l}\text { Cursos pré- } \\
\text { vestibulares } \\
\text { comunitários: } \\
\text { leitura de } \\
\text { literatura } \\
\text { brasileira com } \\
\text { vistas ao } \\
\text { vestibular, } \\
\text { mediação de } \\
\text { leitura pelos } \\
\text { profs., acesso a } \\
\text { material } \\
\text { impresso. }\end{array}$ \\
\hline
\end{tabular}




\begin{tabular}{|c|c|c|c|c|c|}
\hline TAIKO & $\begin{array}{l}\text { EF I: Leitura de livros } \\
\text { infantis. Ocasional. }\end{array}$ & $\begin{array}{l}\text { EF I: Leitura para a } \\
\text { escolarização. } \\
\text { EF II e EM: Leitura } \\
\text { por obrigação. } \\
\text { Leitura como algo a } \\
\text { sonegar aos alunos. } \\
\text { Leitura como algo } \\
\text { passível de ser } \\
\text { aprendido. }\end{array}$ & $\begin{array}{l}\text { Profas. da } 1^{\mathrm{a}} \text {. à } 4^{\mathrm{a}} \text {. série: Leitura de livros infantis } \\
5^{\mathrm{a}} \text {. série ao } 2^{\mathrm{o}} \text {. ano do EM: escola interpõe barreira à } \\
\text { leitura. } \\
\text { Difusão da concepção de leitura por obrigação. } \\
\text { Incredulidade com as práticas de leitura do sujeito. } \\
\text { Alguns professores foram barreiras à escolarização. } \\
\text { Profa. LP na } 8^{\mathrm{a}} \text {. série: Estudo de obra literária, sanando } \\
\text { dúvidas. Preparo de aula e demonstração de interesse em } \\
\text { ajudar os alunos. } \\
\text { Profa. de LP no } 1^{\circ} \text {. ano EM: Seminários sobre clássicos } \\
\text { da LB. Mostrou que ler é bom, explicou fases literárias, } \\
\text { deu auto-avaliação. Foi exigente. }\end{array}$ & $\begin{array}{l}\text { Incentivo à } \\
\text { leitura de obra } \\
\text { completa por } \\
\text { meio de } \\
\text { trechos da } \\
\text { obra. }\end{array}$ & $\begin{array}{l}\text { Palestras e } \\
\text { impressos da } \\
\text { EDUCAFRO } \\
\text { com } \\
\text { orientações } \\
\text { para a escolari- } \\
\text { zação e sobre } \\
\text { leituras para o } \\
\text { vestibular da } \\
\text { universidade } \\
\text { pública. }\end{array}$ \\
\hline ZAPATA & $\begin{array}{l}\text { De modo geral, não. } \\
\text { Escola foi a principal } \\
\text { barreira. } \\
\text { EF II: propostas de leitura } \\
\text { que o sujeito não fazia } \\
\text { por barreira de acesso. } \\
\text { Ocasional. } \\
\text { EM: propostas de leitura. } \\
\text { O sujeito não fazia todas } \\
\text { por preconceito contra } \\
\text { literatura. Idas à BP para } \\
\text { trabalhos escolares. } \\
\text { Ocasional. }\end{array}$ & $\begin{array}{l}\text { Leitura para a } \\
\text { escolarização. } \\
\text { Leitura por } \\
\text { obrigação, como } \\
\text { mera tarefa escolar. }\end{array}$ & $\begin{array}{l}\text { Mediação pouco significativa, baseada em } \\
\text { memorização.Escola pouco desafiadora. } \\
\text { Gostava de alguns bons professores, que eram exigentes. } \\
\text { Profa. da } 2^{\text {a }} \text {. série do EF: comprometida e exigente, } \\
\text { incentivou a escolarização, combateu absenteísmo e } \\
\text { forneceu-lhe livros didáticos e material escolar. } \\
\text { Profs. de LP do EF II e de todo o EM: difusão de } \\
\text { concepção de leitura por obrigação. Despertar de } \\
\text { interesse por literatura a partir de leitura de uma obra } \\
\text { específica. }\end{array}$ & $\begin{array}{l}\text { Cartilha foi } \\
\text { fonte de } \\
\text { narrativas que } \\
\text { foram } \\
\text { discutidas } \\
\text { entre os } \\
\text { irmãos. }\end{array}$ & $\begin{array}{l}\text { Graduação em } \\
\text { Letras: } \\
\text { mediação de } \\
\text { obras clássicas } \\
\text { da literatura } \\
\text { brasileira. } \\
\text { Sedução para a } \\
\text { leitura de } \\
\text { alguns autores. }\end{array}$ \\
\hline $\begin{array}{l}\text { Legenda } \\
\text { BE: Bibli } \\
\text { BP: Bibli } \\
\text { EF: Ensir } \\
\text { EF I: } 1^{\circ} \text {. } \\
\text { EF II: } 2^{\circ} \text {. } \\
\text { EM: Ensi } \\
\text { LD: Livr } \\
\text { LP: Líng } \\
\text { OME: Ot }\end{array}$ & $\begin{array}{l}\text { ca escolar } \\
\text { a pública } \\
\text { undamental } \\
\text { nento do Ensino Fundam } \\
\text { mento do Ensino Fundam } \\
\text { médio } \\
\text { dático } \\
\text { ortuguesa } \\
\text { modalidades de escolari }\end{array}$ & $\begin{array}{l}\left.\text { ntal (1 } 1^{\mathrm{a}} . \text { à } 4^{\mathrm{a}} \text {. séries }\right) \\
\text { ntal (5ão }\end{array}$ & & & \\
\hline
\end{tabular}




\subsubsection{A mediação de leitura na escola - Grupo A (os leitores)}

Depreende-se dos depoimentos dos 8 sujeitos do grupo A que, de modo geral, a escola foi extremamente omissa quanto à mediação de leitura. As práticas de leitura na escola ou não foram fomentadas ou foram propostas e mediadas de maneira pouco atraente durante toda a trajetória escolar de alguns sujeitos e em longos períodos da trajetória de outros. Lembrar-se de alguma prática significativa e prazerosa foi exceção e não regra. Além disso, a escola impôs barreiras de acesso ao texto impresso à escolarização e à formação leitora da maioria deles. No primeiro segmento do Ensino Fundamental, apenas 3 dos 8 sujeitos lembram-se de ter desenvolvido práticas de leitura. No segundo segmento, esse número cai para dois. No Ensino Médio, foram solicitadas leituras a 7 sujeitos, mas apenas 2 estiveram envolvidos em práticas pedagógicas interessantes. A responsabilidade pelo desenvolvimento de práticas de leitura recaiu exclusivamente sobre o professor de Língua Portuguesa e somente 4 dos 8 sujeitos interagiram com outros leitores (para além desse docente) no ambiente escolar. A mediação pelo livro didático de Língua Portuguesa foi irrelevante ou negativa para a vasta maioria, porque não foi adotado ou foi mal utilizado.

As práticas de leitura na escola - para além da mera leitura do livro didático ou da cópia da lousa, da ida à biblioteca escolar (se ela existia) para "tirar matéria" (já que nem todos tinham livros didáticos) ou da realização de eventuais pesquisas em bibliotecas públicas para fazer cópias para trabalhos em grupo - caracterizaram-se pela inexistência, intermitência e baixa frequiência para 7 dos 8 sujeitos do grupo A de leitores. A exceção parece ter sido Paula no período que se estendeu da $5^{\mathrm{a}}$. série do Ensino Fundamental ao $2^{\circ}$. ano do Ensino Médio.

Ao menos 5 sujeitos - AK47, André, Dandara, Maria e Marley - verbalizaram que a escola deu-lhes pouco incentivo à leitura:

AK47: E depois que eu passei da idade escolar, eu não lia mais nada porque você não tem acesso à biblioteca da escola e das escolas que eu passei quando eu entrei na escola, só uma aqui na Tiradentes que eu cheguei a ir na sala de leitura. Nas outras, eu nem sabia que existia biblioteca.

André: A escola teve a questão da [Coleção] Vaga-lume. Mas depois disso deu uma brecada. Então, a escola até fica. A biblioteca da escola em si não funciona, né.

Dandara: Na escola, a gente nunca ia muito pra sala de leitura. Então, eu não lia muitos livros, aí eu lia os livros que tinha em casa, né, aí... Assim, depois assim, que eu comecei a ler mesmo foi depois que, de adulto, né, e... Quando entrei pra biblioteca [BCST], aí eu comecei a ler mais. [...] Ler, ler, não [os professores não me incentivaram a ler]. Que eu me lembre eu não vi nem... [...] Aí não lembro [de nenhum professor que me deu incentivo a ler]. [...] Pra incentivo à leitura, acho que não, porque eu adquiri só mesmo aqui [na BCST] mesmo pra ler. 
Maria: Então, de primeira à oitava série, não tenho nenhuma recordação em relação a isso [os professores pedirem para ler alguma coisa]. Eu estudei numa escola aqui na Cidade Tiradentes. [...] Então, a escola não foi determinante no meu envolvimento e prazer pela leitura, entendeu, nem um pouco relevante. [...] Bem, no ensino fundamental, eu acho que a escola teve um papel muito negativo. Primeiro, porque o ensino, da forma como ele é dado: você passa o ano todo estudando aquilo; chega no outro ano, você já não lembra de mais nada. A coisa é posta de um jeito que parece que é pra tirar um pouco do conhecimento que você tem. [...] O professor tem a postura do que sabe tudo e nós somos os vazios que estão ali pra ser preenchidos com o conteúdo deles. Hoje, eu faço essa leitura. Então, pra mim, a escola teve esse papel mais negativo.

Marley: A escola [não me ajudou a me tornar leitor]. Escola horrorosa. É o que eu chamo de educação bancária. Você decora. É a formulazinha. Decorou, tirou nota na prova e acabou. Vai aprender o quê? Raro o professor que vez ou outra falava isso, mas você tem oito professores, um fala isso e o todo como fica? Porque a escola até chegar na sala de aula em quantas portas com cadeado você passou? A própria forma que está organizada a escola ela não é para te estimular no processo educacional criativo.

Os relatos da vasta maioria dos sujeitos evidenciaram que a escola lhes impôs, em algum momento, uma barreira de acesso ao material impresso, e, portanto, à sua constituição como leitores, seja porque ela não dispunha de biblioteca escolar, seja porque não permitia a circulação do acervo, seja porque tal acervo consistia, sobretudo, de livros didáticos, ou simplesmente porque, no ambiente da biblioteca escolar, não havia qualquer atividade de mediação da leitura:

\begin{abstract}
AK47: Só que a gente chegava lá na sala de leitura e ficava vendo os livros. A professora não falava nada. A gente só pegava livro e ficava vendo. Não [tinha nenhuma atividade], não tinha nada e aí a gente escolhia um livro para ler, quem conseguia ler e gostava, lia os livros lá, mas essa era a relação que eu tinha com a sala de leitura.
\end{abstract}

Dandara: Ah, que eu me lembro, acho que não [podia levar livros pra casa]. Acho que não podia levar pra casa, o trabalho tinha que ser feito lá, e a gente só podia ler quando os professores levavam. Eu não sei, eu não lembro se era, se tinha um dia fixo ou alguma coisa assim. Eu só sei que a gente lia o livro lá, aí acabava o horário, você tinha que ler na próxima vez que fosse lá. Você não levava o livro pra casa e terminava de ler ele.

Frida: [Quando eu vim para Cidade Tiradentes, a biblioteca das escolas] não emprestava os livros. Não emprestava. Tinha também esses momentos de leitura, né, mas eu nunca fui de ir na biblioteca da escola pegar o livro, fazer o trabalho. Eu sempre fui em biblioteca fora. Então, por exemplo, eu ia em Guaianases, que é a biblioteca que eu lembro na época, né. E agora tem umas mais próximas assim, pública. Mas naquele tempo era só a de Guaianases, que eu me lembre. Aí eu ia lá fazer trabalho. [Lá eu] pegava. Pegava livro emprestado. [...] Eu só não pegava livro para ler, era mais para fazer trabalho. E aí já foi o momento que distanciou da leitura, né. É, porque aí, como você só vai pra aquela finalidade de pegar o livro pra fazer o trabalho, não é uma coisa que é só pra você ler por prazer porque você gosta, né?

Laís: A única biblioteca que tinha era na escola e ela não era muito aberta, na realidade, para os alunos. Eles falavam que era, mas era muito restrita... pra gente pegar livro. Era mais livro didático que eles davam pra gente tirar matéria. Mas pra ler mesmo, no comecinho, teve um momento em que eles deixavam a gente levar o livro e levar pra casa. Mas sempre tem uns que não sabem o que fizeram, que somem com o livro. Mas daí eles tiraram, porque antes eu também pegava livro na escola. Mas aí eles tiraram. Não tinha como pegar o livro pra você ficar lendo, até pra distrair a mente...

Maria: Porque eu me recordo bem que a escola sempre ficava fechada. A escola, não. A biblioteca da escola sempre ficava fechada, agora eu não lembro direito de... Eu não me recordo [de ir à biblioteca da escola]. Quando tinha que fazer um trabalho ou alguma coisa, eu ia sempre na minha vizinha, pegar 
revista, pegar livros. Era mais fácil, não era tão chato. Não tinha que enfrentar aquela mulher com aquela cara tão brava que sempre tem na escola quando você quer alguma coisa.

Marley: Então, não porque... falido na escola. E a pessoa responsável por mexer no livro dizia: "Tá cheio de pó". Isso não dá autonomia para o aluno mexer, conhecer. Logo dizia: "Ah, vai bagunçar." Vinte alunos para ler um livro. [...] Em tudo quanto é escola que eu já fui. Não tem uma didática, uma metodologia, contação de história, nunca vi isso não. Eu faço, mas nunca fizeram comigo.

Para facilitar a análise das práticas de leitura que porventura existiram, optei por dividi-la em: $1^{\mathrm{o}}$. segmento do Ensino Fundamental (1 $1^{\mathrm{a}}$. à $4^{\mathrm{a}}$. séries), $2^{\mathrm{o}}$. segmento do Ensino Fundamental ( $5^{\mathrm{a}}$. à $8^{\mathrm{a}}$. séries $)$ e Ensino Médio.

Cinco sujeitos - AK47, André, Dandara, Maria e Paula - não desenvolveram práticas de leitura para além daquelas estritamente ligadas à alfabetização, no âmbito da escola no $1^{\text {o }}$. segmento do Ensino Fundamental. Apenas 3 dos 8 sujeitos - Frida, Laís e Marley - estiveram envolvidos em atividades de leitura compartilhada de literatura infantil. Os sujeitos não puderam precisar a frequiência de tais atividades, mas elas parecem ter se desenvolvido com relativa constância. Elas foram conduzidas pela professora do Ensino Fundamental, e consistiram de: leitura de literatura infantil na sala de aula ou na biblioteca; e solicitação de leitura em voz alta pelos alunos para verificar entonação. Apenas 2 sujeitos - Frida e Laís parecem ter desenvolvido alguma práticas de leitura mais autônoma: livros infantis no caso de Frida e a Bíblia, no de Laís. Porém, apenas Frida relatou ter ido à biblioteca escolar, algo que fez somente até os 8 anos.

Tais oportunidades de leitura parecem ter sido bastante marcantes para os 3 sujeitos, embora de modos diferentes. Frida e Laís, além de gostar das atividades de leitura, desenvolveram uma relação de grande afetividade com as respectivas professoras, em especial com aquelas dos anos iniciais do Ensino Fundamental. Já Marley não se identificou com os protagonistas das histórias infantis lidas, e foi motivo de piadas entre os colegas, que parecem ter provocado um início de reflexão sobre questões raciais e, alguns anos depois, contribuído para a busca de leituras sobre o assunto.

Vejamos a seguir trechos dos relatos desses três sujeitos, que constituem exceção em seu grupo, por terem desenvolvido algumas práticas de leitura no $1^{\circ}$. segmento do Ensino Fundamental:

Frida: [Eu pegava os livros de literatura infantil] na biblioteca da escola. Porque a maioria das escolas tem biblioteca, né. Como eu não morava aqui na Cidade Tiradentes, então na escola que eu estudava tinha biblioteca, você podia pegar o livro. Aqui já tem um acesso mais restrito.

$[\ldots]$

Antes, eu morava no Jaçanã, na zona norte. [...] Eu vim para cá, eu tinha oito anos. [Lá na biblioteca do Jaçanã] era a professora que levava. Depois você poderia também ir na biblioteca pegar, mas aí eu já não me lembro, porque, como eu era muito nova, eu já não lembro se eu chegava a ir muitas vezes. 
Mas eu sei que a professora sempre trazia algum livro e tinha dias que era o dia da leitura, então, é uma forma que acho que dá estímulo a ler, né. [Eu] gostava, gostava [de ir à biblioteca]. Lembro mais ou menos [da biblioteca]. Tinha a estante, tinha a mesa, acho que a mesa era redonda, tinha umas cadeirinhas, era um espaço - como se fala? - bem... Bem tranqüilo de ler. E bem organizado também. Era uma escola muito organizada. Eu gostava daquela escola. Era uma escola bem boa, não sei se está boa ainda, mas era muito boa. [Eu] gostava, gostava da professora também. [...] Professor [que tenha me incentivado a ler]? É... Maria Angélica é o nome da professora e era do prezinho, eu tenho a foto dela lá em casa até hoje. [...] Ela era muito comprometida com os alunos. Então, ela sempre incentivava a ler, a escrever. Então, eu gostava muito daquela professora, gostava mesmo, gostava muito, muito, muito mesmo. Professora bem mais marcante assim. [...] Professora bem legal. Agora, tem a professora que me alfabetizou, que é a Sonia. [...] É legal [dar entrevista] porque resgata um pouco lá atrás e a gente também não esquece que foi criança, quem incentivou a ler. Não esquece a professora do pré. [...] É, [talvez eu tenha sido boa aluna sempre] porque teve um início [positivo]. O início... acho que o que eu sou hoje tem a ver com o lá atrás. Dessa professora, por exemplo, do pré. Então, ela foi muito importante pra mim e que fez o diferencial, porque não só minha família, mas sempre o incentivo a ler, a escrever.

Laís: Com o tempo, mesmo, a professora falou: "A sua filha é maravilhosa. Ela entende e interpreta bem, mas ela tem de ter um incentivo na leitura". [...] Eu tava na $2^{\mathrm{a}}$. série do fundamental. E essa professora é maravilhosa, excepcional ela. Eu gostava muito dela. E ela falou pra minha mãe: "Incentiva ela a ler. Já que ela tem mania de ler a Bíblia, esses negócios de igreja, dá a Bíblia para ela ler, de pouquinho em pouquinho, salmos, provérbios, que é uma linguagem mais pra jovens, crianças, coisas mais simples, provérbios, sabedorias". Então, eu comecei assim. Que ela falou assim: "vai te ajudar muito no seu vocabulário, pra você mudar a sua linguagem errada". Aí eu comecei a ler a Bíblia.

Então, a Bíblia era meu livro. Aí, conforme o tempo, tinha professores que falavam de certos livros, que chamavam a atenção dos alunos para a leitura, faziam o máximo pra gente ler. Tinha uma professora mesmo, que era japonesa, e era Margarida o nome dela, e eu vi assim que ela era muito calma, ela fazia leitura de livros de literatura. Ela pedia pra gente fazer leitura pra ver se a gente interpretava bem, se a gente tinha uma boa fonética na leitura. E ela era tão calma que, às vezes, a sala não dava muita atenção pra ela, mas ela sabia os alunos que estavam aprendendo.

Marley: [A escola] ajudou. Mas, assim, nesse negócio de ler, porque minha mãe nunca leu as histórias infantis, mas na escola a gente lia. Na escola tinha uma professora de leitura. Ela lia algumas histórias, eu dava risada. Pinocchio também, dizia: - Nossa tem muita gente que vai ter nariz grande. Mas aí vinha umas piadas: É, mas seu nariz já é grande. Já vinha umas piadas que eu não sabia na época me defender. Um certo príncipe era diferente de mim. E eu: Mas por que isso? Até os heróis são diferentes de mim. Eu ficava refletindo isso, bastante. Uma vez, eu cheguei numa menina e falei: "Eu quero ficar com você”. E ela me disse: “Ó, eu não fico com negro”. Primeira vez que alguém falou. Porque minha mãe nunca falou. Pra minha mãe, eu sou moreno. Para a polícia, eu sou negão e, na minha opinião, eu sou preto. Então, assim... E isso acabou estimulando um pouco: Peraí, tem alguma coisa errada nesse mundo...

Depreende-se dos relatos dos 3 sujeitos que as concepções de leitura presentes na escola nesse período tenham sido de leitura por prazer, leitura para escolarização e conseqüente emancipação econômica e ascensão social:

Frida: Mas eu sei que a professora sempre trazia algum livro e tinha dias que era o dia da leitura, então é uma forma que acho que dá estímulo a ler, né. [Eu] gostava, gostava [de ir à biblioteca].

Marley: Na escola, a gente lia. Na escola tinha uma professora de leitura. Ela lia algumas histórias, eu dava risada. Pinocchio também, eu dizia: "Nossa! Tem muita gente que vai ter nariz grande!".

Laís: Então, eu comecei assim. Que ela falou assim: "vai te ajudar muito no seu vocabulário, pra você mudar a sua linguagem errada". Aí, eu comecei a ler a Bíblia.

Frida: Para mim, eu acho que o ensino fundamental foi melhor. Até no sentido de incentivar a leitura, porque os professores, pelo menos os que eram meus professores, sempre incentivou a ler, que era uma 
coisa importante que trazia conhecimento, que trazia informação e que isso futuramente ia te trazer um retorno.

Além de a maioria dos sujeitos do grupo A ter desenvolvido pouquíssimas práticas de leitura no âmbito da escola no $1^{\circ}$. segmento do Ensino Fundamental, para além daquelas estritamente vinculadas à alfabetização, ao menos 7 deles - AK47, André, Dandara, Laís, Maria, Paula e Marley - enfrentaram algum tipo de barreira à escolarização ao longo do Fundamental. Dentre tais barreiras, os sujeitos citaram: dificuldades de aprendizagem (5), estratégias metodológicas pouco envolventes (3), hostilidade por algum professor (2), falta de livros didáticos (1), falta de vagas (1), receio da violência escolar (1) ou, simplesmente, uma relação muito negativa com a escola (1). Tais barreiras parecem ter prejudicado seu aproveitamento escolar em algum momento. Quatro desses sujeitos - AK47, Dandara, Paula e Marley - chegaram a ser reprovados em alguma série do Fundamental ${ }^{85}$. Marley, que sempre pautara sua relação com a escola pela indisciplina, a partir de uma expulsão na $4^{\mathrm{a}}$. série, passou a ver a instituição e o professor como "os inimigos".

No $2^{\circ}$. segmento do Ensino Fundamental, 6 sujeitos - AK47, Dandara, Frida, Laís, Maria e Marley - parecem ter desenvolvido ou pouquíssimas ou absolutamente nenhuma prática de leitura no âmbito da escola, para além daquelas estritamente ligadas a tarefas escolares, como por exemplo, ler e copiar textos da lousa ou copiar textos na biblioteca pública para eventuais trabalhos em grupo. A interrupção nas práticas de leitura de 2 sujeitos - Frida e Marley - foi especialmente longa, já que se estendeu da $3^{\text {a }}$. à $8^{\text {a }}$. séries. Isso para não falar em duas pesquisadas - Dandara e Maria - que não se lembram de ter sido solicitadas a ler absolutamente nenhum livro durante todo o Ensino Fundamental.

Apenas 2 sujeitos - André e Paula - foram exceções à regra de extrema restrição de práticas de leitura. André leu a Coleção Vaga-lume ${ }^{86}$ recorrendo a empréstimos de colegas e da própria professora, enquanto Paula desenvolveu práticas de leitura constantes no âmbito da escola, e teve acesso à biblioteca escolar com acervo circulante inclusive nas férias. Para ambos, a professora foi modelo de leitora e promoveu atividades de leitura de literatura juvenil. A mediação de leitura para André consistiu de incentivo à leitura, leitura de trechos dos livros em voz alta pela professora e fornecimento de outros trechos para os alunos lerem. No caso de Paula, houve, além do incentivo à leitura, elogio à qualidade da narrativa, estímulo ao uso do dicionário, interlocução da professora com os alunos, numa relação que às vezes

\footnotetext{
${ }^{85}$ Dandara na $1^{\mathrm{a}}$. série, Paula na $2^{\mathrm{a}}$., Marley na $3^{\mathrm{a}}$. e $4^{\mathrm{a}}$. e AK47 na $6^{\mathrm{a}}$.

${ }^{86}$ Série de obras de literatura infanto-juvenil publicada pela Editora Ática.
} 
parecia simétrica, sobre livros e leituras, durante a qual a professora demonstrava ainda interesse pelas opiniões dos alunos, parecendo aceitar também sugestões de leitura deles. Ambos os sujeitos beneficiaram-se do fato de ter uma professora efetiva de Língua Portuguesa por vários anos, algo incomum na trajetória da grande maioria deles, que se ressentiram da falta de professores ou de sua alta rotatividade. André e Paula relataram:

\begin{abstract}
André: E aí a Vera, que era minha professora de Português na época, ela começou a trabalhar muito com a gente aquela Coleção Vaga-lume, lembra? [...] Da quinta à oitava e eu lembro que o primeiro que a gente leu foi Do Outro lado da Ilha. Aí, eu li e gostei. Falei: "Pô, é legal, meu!" Aí, eu fui começando a pegar com os rapazes mais velhos do prédio. Eu perguntava: "Você tem algum livro da Coleção Vagalume?" Ela começava a ler e trazia alguns livros. [A professora] lia em voz alta, pegava textos para nós lermos. E eu perguntava: "E esse livro aí professora, fala do quê?". E ela respondia: "Fala sobre isso, isso e isso". Eu dizia: "Me empresta?". Ela: “Ah, beleza, você tem algum lá?”. Eu dizia: "Tenho". E aí começava. E assim foi indo. Meus irmãos também usavam, o mais velho, o Márcio, o Neto e tal. Então, pegava o deles e lia, comecei a ler muito.
\end{abstract}

Paula: [Na escola, o único professor que me incentivou a ler foi] mais essa professora mesmo de português que às vezes ela fazia a gente ler assim, mas às vezes ela conversava com a gente e a gente acabava começando também a gostar de conversar com ela e ela falava para nós que ler é importante... [...] Nossa, ela sempre foi [minha professora], né? Desde a quinta série até a gente... ficamos lá até a oitava, né? [perguntando para Beatriz]. Até o segundo colegial, nós ficamos lá. [...] Ela era [uma professora] assim mais do tipo amiga. Ela conversava com a classe inteira. [...] Ela falava às vezes sobre nós, conversava conosco sobre nós mesmos. Sabe, assuntos nossos... dela assim e às vezes de livro, que era bom a gente ler, que a história era interessante, muitas vezes a gente não ia gostar, a gente não ia entender, mas que era muito bom a gente ler. Que se a gente não entendesse, pegasse o dicionário... Aí, depois aí... Foi assim que a gente começamos também a querer ler... [A professora] ficava [orgulhosa quando via nosso grupinho lendo]. Ela vinha e falava que era muito bom a gente ler, perguntava que livro a gente estava lendo, ela dizia se já tinha lido. Se ela não tinha lido, ela perguntava para gente se era bom, para ela ler também.

As concepções de leitura no $2^{\circ}$. segmento do Ensino Fundamental para André e Paula parecem ter sido leitura como fonte de lazer/prazer, leitura para a escolarização, leitura para obtenção de conhecimento, leitura como algo passível de se aprender:

André: Aí, eu li e gostei. Falei: "Pô, é legal, meu!"

Paula: [A professora] falava para nós que ler é importante... [...] falava às vezes de livro, que era bom a gente ler, que a história era interessante, muitas vezes a gente não ia gostar, a gente não ia entender, mas que era muito bom a gente ler. Que se a gente não entendesse, pegasse o dicionário...

O $2^{\circ}$ segmento do Ensino Fundamental foi especialmente importante para que André que apresentara dificuldades de aprendizagem nos primeiros anos do Fundamental, tivera receio da violência na escola e se sentira hostilizado por alguns professores - passasse a se dedicar mais aos estudos, aumentasse seu aproveitamento escolar, em particular nas disciplinas de ciências humanas, e passasse a perceber-se como um "bom aluno" e como alguém com facilidade para compreender textos. Para tal mudança, parece ter sido crucial a atuação de uma professora com a qual o sujeito tinha uma relação de forte afetividade: 


\begin{abstract}
André: Tinha uma professora que chamava Shirley que, nossa, eu odiava. Ela dava aula de geografia e a geografia [eu] não via como ia me ser útil aqui. Eu pensava: "Para quê eu vou estudar geografia? Se eu não vou sair de São Paulo e não quero sair de São Paulo, por que eu tenho que saber do Amapá?". E ela tinha uma marcação ferrenha em cima de mim. E então, ela tinha um critério, era tipo assim: "Você vai fazer uma prova surpresa agora!" Eu dizia: "Mas como?" Ela dizia: "Sobre tudo o que você já estudou". Essa era a [professora] de Geografia. Eu odiava. Teve até um dia que eu virei para uma das professoras, a professora de Ciências, a Rolandi, que ela era muito gente fina, ela tinha um carinho comigo assim muito grande. Aí, as duas estavam conversando e sabe quando você esbarra numa pessoa sem querer? Eu falei: "Ai, desculpa, professora". E ela disse: "Não foi nada". E veio e passou a mão na minha cabeça de uma forma carinhosa. E ela estava com a Shirley e ela me olhou assim (meio torto) e eu falei: "Olha, professora, [...] eu queria saber por que ela não gosta de mim”. Aí a Shirley falou: "Não, não é assim [...] Eu trato todo mundo igual". Eu disse: "Não, é diferente, você me trata diferente, eu sei. Parece que você não gosta de mim". Aí a Rolandi chegou e ela disse: "Depois, eu converso com você". Aí ela falou para mim: "Por que você falou isso? Aí eu disse: "Porque só para mim ela faz isso, todo mundo bagunça e ela só aponta para mim, se eu vou virar para falar alguma coisa com alguém, ela fala: "Não, você vai fazer um trabalho agora. Aí ela falou para mim: "Sabe o que você faz? Presta atenção: já que você sabe que ela vai dar essa prova só para você, você estuda"... Essa professora Rolandi era de Ciências, Biologia. Então, ela falou: "Estuda tudo o que ela já passou. Quando ela te der uma prova surpresa e você tirar um A, ela vai parar". Aí eu falei: "Vou fazer isso aí, professora". Ela disse: "Quero ver essa prova". Eu falei: "Está bom". E ela disse: "Você quer um doce, você quer um lanche? Quer um toddynho?". Porque, naquela época sempre se dava um toddynho e ela guardava e dava para mim. Eu disse: "Eu quero". Aí, eu fiz isso daí. Eu disse: "Ah, já sei... prova surpresa". Ela disse: "É". Eu disse: "Tá bom". [...] Aí, eu comecei a ver que na escola era o seguinte: que tinha coisas que eu tinha muita dificuldade e outras que eu tinha muita facilidade. Humanas, eu sempre fui bem. A, eu comecei: História, Geografia... Sempre fui muito bom com datas, interpretar os textos em literatura...
\end{abstract}

Em contraste com a experiência mais "positiva" que André e Paula parecem ter vivido no $2^{\circ}$. segmento do Ensino Fundamental, é interessante citar o caso diametralmente oposto de Marley, sujeito que experimentou atitudes pedagógicas equivocadas dos professores de Língua Portuguesa em geral e de uma em particular, que ridicularizou seu desejo de ler, que havia recentemente sido mobilizado pelo contato com o rap:

\footnotetext{
Marley: Não, [em nenhum momento o professor de LP me ajudou a ler]. De jeito nenhum, quando eu acertava tudo, a professora ficava brava. Ela falava: "Que absurdo!" E eu dizia: "Pois é, professora, como eu sou obrigado a conhecer esse idioma do opressor, então, eu vou fazer o quê?" E ela [respondia]: “É, mas você não pode subestimar uma língua tão maravilhosa dessa!" [E eu respondia:] É, mas ninguém quer ensinar africano. E a professora [respondia]: "Ah, mas vai aprender africano? Para quê? Por quê? Palhaçada."

[...]

O Nelson Triunfo disse: “Cara, é o seguinte mano, vai lá na biblioteca. Tem coisa boa lá, mano. Não fica esperando, não. Mas na escola também tem coisa boa, mas você tem que aprender a ler. Porque você não pode ficar negando a leitura, conhecimento está lá. Você tem que conhecer tudo". [Eu pensei:] "Ah, interessante". Eu dialoguei isso com a professora de português. Ela disse: "Ai que maravilha, o mais atentado agora está preocupado em ler!” [Ela falou] ironicamente, tanto que eu joguei a cadeira nela. [...] É, joguei nela, foi na sexta. Sexta, sétima. Sétima série. Fui chamado, novamente meu nome no livro negro.
}

Outro caso chama a atenção pela forma pouco atraente como a leitura foi apresentada.

AK47 teve a rara oportunidade de visitar uma sala de leitura pela primeira vez na $6^{\mathrm{a}}$. série, mas não foi envolvido em absolutamente nenhuma atividade: 


\begin{abstract}
AK47: Eu vim saber o que era uma sala de leitura na sexta série aqui no Ana Lambert. Aí que eu soube que existia sala de leitura nas escolas e aí a professora de Língua Portuguesa levava a gente para a sala de leitura. Só que a gente chegava lá na sala de leitura e ficava vendo os livros. A professora não falava nada. A gente só pegava livro e ficava vendo. Não [tinha nenhuma atividade], não tinha nada e aí a gente escolhia um livro para ler, quem conseguia ler e gostava, lia os livros lá, mas essa era a relação que eu tinha com a sala de leitura.
\end{abstract}

No Ensino Médio, foram solicitadas leituras a todos os sujeitos do grupo A de leitores, com exceção de Dandara. No entanto, a freqüência das leituras foi bastante reduzida. Além disso, de acordo com os relatos de 5 dos 7 sujeitos $^{87}$ a quem foram feitas propostas de leitura na escola, o trabalho com a leitura de literatura de modo geral e das obras de literatura brasileira parece ter sido incompleto, insuficiente, negativo ou quase sempre mal-sucedido. Os sujeitos ressentiram-se da forma pouco interessante como as leituras foram apresentadas, e alegaram ter tido dificuldades de compreensão de sua linguagem e incompreensão ou não identificação com a temática das obras. Oferecemos abaixo um quadro dos motivos apresentados pelos sujeitos para a não leitura:

\begin{tabular}{|l|c|c|c|c|c|}
\hline Motivos declarados para não ler literatura & AK47 & André & Frida & Marley & Paula $^{\mathbf{8 8}}$ \\
\hline Não gostar de literatura de modo geral & $\mathrm{x}$ & & & & \\
\hline Dificuldades com a linguagem & $\mathrm{x}$ & $\mathrm{x}$ & $\mathrm{x}$ & $\mathrm{x}$ & $\mathrm{X}$ \\
\hline Não geração de interesse (aborrecido) & $\mathrm{x}$ & $\mathrm{x}$ & $\mathrm{x}$ & $\mathrm{X}$ \\
\hline Não identificação com a temática & & $\mathrm{x}$ & $\mathrm{x}$ \\
\hline Caráter obrigatório (mera tarefa escolar) & & $\mathrm{x}$ & & \\
\hline O vestibular como finalidade da leitura & & $\mathrm{x}$ & \\
\hline
\end{tabular}

Vejamos o que os sujeitos relataram:

\begin{abstract}
AK47: No ensino médio, [não li] nada também. Eu lembro que a professora mandava ler algumas obras, mas eu nunca gostei de ler literatura brasileira, porque eu pegava o livro e sempre estranhei a linguagem da literatura brasileira. Até hoje, eu estranho, eu estranho. [...] Então, na época, a questão da linguagem me afastou muito de ler.
\end{abstract}

\begin{abstract}
André: [Os professores] forçam, depreciam... não sei, não gosto de usar muito esse termo depreciar, porque é meio pejorativo, mas obrigam o aluno a ler um livro de uma leitura cansada, que é uma leitura antiga, arcaica, cansada, onde ele não consegue interpretar direito o texto, como Camões em $O s$ Lusíadas. [...] Tive que ler, qual o outro? Clarice Lispector, ótimos escritores, ótimos escritores para níveis universitários que já têm uma interpretação de texto mais avançada. Você dá para um moleque de
\end{abstract}

\footnotetext{
${ }^{87}$ Conforme disse anteriormente, a Dandara aparentemente nenhuma solicitação de leitura de literatura foi feita no ensino médio.

${ }^{88}$ No caso de Paula, houve boa mediação de outros livros, em especial de literatura infanto-juvenil.
} 
periferia que está ouvindo funk, axé, essa musicalidade, e você dá um livro desse para o cara e obriga o cara a ler, o cara nunca mais querer pegar um livro na porra da vida dele. [No ensino médio, a professora de LP] continuava sendo a Vera. [Aí] não [foi tão legal quanto a Coleção Vaga-lume]. A Vera, ela falava: "Você tem que ler porque, se você quer entrar na faculdade, vai cair. Então, você tinha que saber umas leituras que ela falava: "Meu, se você for para a faculdade, isso vai cair, cara". Eu dizia: "Mas professora, essa leitura é chata demais, essa leitura eu não gosto". [E ela respondia]: Mas é a leitura que o sistema pede que você saiba. Agora, se dependesse de mim, nessa época, eu leria qualquer livro sobre religião, História, matriz africana, alguns sobre fotos, alguns ilustrados, alguns para você conhecer alguns locais do mundo, coisas do gênero, mas não uma leitura obrigatória. Porque o cara pega aquilo lá, os jovens principalmente, os jovens, quando têm o primeiro contato com o livro, tem que ser uma coisa que ele goste, porque tudo que você faz com prazer você faz bem. Tudo que você faz obrigado, você faz nas coxas.

Frida: Não gostei [de ler literatura brasileira no ensino médio]. Talvez, não sei se foi da forma como trouxe, mas eu não gostava não. E não gosto ainda de literatura, essa clássica assim. Se você pegar Barroco, eu não gosto dessas leituras. Não dá. Não sei se é porque não tem... Não expressa o que eu vivo, mas eu sei que tem coisas que já passou e que é importante, mas eu não gosto de ler. Sabe aquela coisa chata? Você pegar... Tem uma literatura, por exemplo... Hoje, o pessoal [do Força Ativa] fala que é legal ler Primo Basílio, tem o Lima Barreto... Mas esse gosto de ler, por exemplo... O Lima Barreto é incentivo do pessoal do grupo aqui do Força Ativa. Então, algumas literaturas eu só aprendi a gostar porque eu vi que é... do jeito que o pessoal [do Força Ativa] trouxe, para mim, é diferente. [...] Por exemplo: quando trouxeram Lima Barreto, Cruz e Souza, pelas características deles, de serem negros de escrever... Da forma que eles escreveram, como eles eram tratados naquela sociedade, que eles viviam como negros, né. Então, eu acho legal assim e eu até aprendi a gostar. Mas não é uma coisa que eu quero ficar lendo. “Ah, ficar lendo Lima Barreto!”. Eu sei que é importante e se eu tiver que ler, eu vou ler, mas não que me agrada [risos]. Da forma que está escrito, da forma que eles escrevem, não. [...] Eu acho diferente. Acho diferente. Não sei explicar bem, sei que é diferente. Não é uma linguagem, como eu vou dizer, popular e que é fácil de entender, né. Tem algumas palavras que acrescenta pro conhecimento, mas eu não gosto de ficar lendo.

Marley: Sempre tive muito preconceito com o romance brasileiro. Ah, isso não serve para nada, prefiro ler um rap. Prefiro ler outra coisa. Ah, mas é legal. Legal para quê? Porque assim eu tinha uma visão muito da Academia Brasileira de Letras, língua portuguesa, da influência portuguesa. Não fala de mim, não fala de nada. [...] Era o que chegava para mim. Escola mesmo, em casa, na rua. [Esse preconceito em relação a romance existia] porque o professor dizia "Hoje, a gente vai ler um romance. Aí veio aquelas frases. "Ah, que coisa chata". Aí vinha uma frase: "Ah, uma região inóspita". E não falava a tradução. Ou você ouvia e acompanhava no dicionário ou ia comprar o livro, raro isso. Será que o professor não tinha a sensibilidade de "Pô, essa palavra é um pouco difícil". Já lê e traduz. Qual é o problema? Mas não acontecia e, então, você acabava criando um bloqueio. Enquanto isso, na outra forma de relatar um romance, me vem o rap falando o que eu entendo, trazendo a realidade. Ah, prefiro ouvir rap. Ah, ficar ouvindo essa babaquice que não tem nada a ver comigo, já não chega as outras matérias, agora isso também. Então, tô de boa... [Agora, quanto à chamada literatura marginal], acho que não é nem gostar [de literatura marginal]. É identificação. O cara está falando a real. [...] Eu li vários romances [depois de adulto], mas os caras viajam muito na maionese. Por quê? Para qual classe que eles estão escrevendo, para quem?

Paula: [A professora deu] bastante [aula sobre os clássicos da literatura brasileira]. Às vezes, [a aula] não era tão interessante não. Às vezes, muita coisa difícil, mas às vezes, não era muito bom não, mas às vezes até que a gente acabava gostando do livro, de ler assim a história. O último [livro] que ela falou para nós ler foi Dom Casmurro mesmo, né. Que a gente chegou a ver o filme na escola. Chegamos a ver o filme primeiro. Aí, depois ela falou que seria bom a gente ler a história.

\section{Os relatos acima evidenciam que a escola não exerceu a contento seu papel de}

descolamento da realidade imediata e de mediação da linguagem e da temática das obras.

Atividades de leituras e análises intertextuais ou a mera apresentação dos autores e suas obras vinculando-os a problemáticas atuais poderiam ter despertado o interesse dos sujeitos por um 
leque mais abrangente de leituras, que incluísse literatura brasileira ${ }^{89}$. Concordo que ler, por exemplo, Os Lusíadas e seu português seja extremamente difícil hoje, mas o mesmo não parece ser verdade a respeito de obras de Clarice Lispector. O fato de mesmo a linguagem dessa autora do século XX parecer tão hermética a André é indício do quanto a escola falhou em favorecer a compreensão de textos que não usam o registro coloquial. Tal falha seguramente deve ter desfavorecido o acesso dos sujeitos a vários tipos de textos não literários.

Depreende-se dos depoimentos que apenas 2 desses 7 sujeitos - Maria e Laís - foram envolvidos em práticas pedagógicas interessantes:

\begin{abstract}
Maria: Mas eu lembro que eu gostava da professora de literatura, a forma como ela colocava a questão... Ela pedia, se eu não me engano, acho que era um livro por mês pra gente ler e aí eu, eu não sei, eu passei... Aquelas aulas, especificamente daquela professora, pra mim, foram positivas. E eu li bastante os clássicos da literatura brasileira por conta daquelas aulas. Mas eu acho que mais por conta da professora, do indivíduo, não da estrutura da escola. Agora, o [colégio] São Paulo era diferente em relação a acesso. A biblioteca era mais, sei lá... Eu recordo que era mais fácil o acesso e tudo mais, fazer a carteirinha, pegar livro emprestado. Eu lembro que era um pouco mais fácil do que aqui. Mas eu acho que foi mais positivo no sentido da professora, não tenho muita recordação dela, mas eu acho que a professora era diferenciada, não a estrutura.
\end{abstract}

Laís: Nacional, acho que só li mesmo da escola. Foi o Dom Casmurro e o Mar Morto, que achei muito legal a história, bem... [...] Do Mar Morto eu achei legal mesmo. Achei boa, que é referente também a uma novela, que a novela Porto dos Milagres foi tirada desse livro. Do Dom Casmurro, eu achei... que todo mundo falando, teve ainda a apresentação na sala, o seminário. Eu achei uma história muito difícil de ser compreendida. [...] Depois eu achei legal mesmo [ler esse livro na escola], porque a gente fica pensando: "Ai, o professor fica dando esses livros para a gente ler". [O professor pedia] Gabriela Cravo e Canela, Anjo, Macunaíma e esse foi o mais difícil de ler porque a linguagem dele é totalmente diferente, um pouco mais difícil e a gente tem essa dificuldade de compreender essa linguagem porque ela é antiga, totalmente diferente, mas ele pediu para a gente esses livros mesmo. Mais literatura brasileira mesmo. [...] Conforme o tempo, eu comecei a gostar sim. Teve uma peça do $O$ Cortiço e a gente adorou porque foi muito bem passada e a nossa sala soube fazer direitinho. [A sala] montou e foi bonito. A gente falou: "Nossa, meu, passou tudinho assim, foi bem como no livro mesmo!". E a gente gostou. Teve essa peça e teve outra peça, mas aí ela foi interpretada porque eles fizeram uma música, né. Aí eles cantaram e depois, nossa, a gente criou muita coisa. A professora soube assim utilizar, montar direitinho. Ela conseguiu passar direitinho o que ela queria e ela incentivou também. [Essa professsora] foi do segundo ano do colégio. Do ensino médio. Isso [foi quando eu tinha 17 anos]. Como eu dizia, ela soube passar para a gente essas coisas importantes, soube integrar a sala também para estar fazendo isso, para estar fazendo a peça e para estar fazendo o seminário também, porque a gente teve que fazer seminário lendo na sala, um tinha que ficar fazendo pergunta para o outro e a gente tinha que saber responder e ela gostava que a gente tivesse noção de tudo que podia cair, principalmente em provões. Ela dava xerox para a gente tirar e para saber interpretar certas perguntas que não estavam no livro, né. A gente tinha que tirar e quem ia fazer ENEM ou provão já tinha uma noção a mais. Ela que empurrou nossa sala nessa questão de leitura. [...] Ela deu um empurrão mesmo e ela era muito dinâmica, extrovertida, alegre. Era muito bom ter um professor assim na sala e esse era o jeito dela mesmo.

\footnotetext{
${ }^{89}$ Como exemplo de análises intertextuais, estão as músicas de grupos pop contemporâneos que citam trechos de clássicos, comparações entre dois gêneros diferentes relatando um mesmo fato (uma notícia da página policial e um poema sobre um crime). Posteriormente, o Força Ativa apresentaria Lima Barreto a Frida, vinculando-o à temática da identidade racial, o que daria outro sentido à leitura de seus livros.
} 
Cabe ressaltar, porém, que, embora a mediação da leitura para Laís e Maria possa ter sido mais positiva, os clássicos da literatura não são obras que elas escolheriam ler hoje.

No Ensino Médio, as concepções de leitura dentro da escola, de modo geral, também não parecem ter favorecido a formação de leitores. Dos 7 sujeitos que desenvolveram alguma prática de leitura, 4 - André, Laís, Maria e Paula - aludiram à concepção de leitura por obrigação, a qual estava ligada à perspectiva de prestar vestibular. Uma outra leitora - Laís fez menção à leitura para aquisição da norma culta. Apenas Paula referiu-se também à leitura como fonte de prazer na escola.

Tudo que se disse até o momento diz respeito à mediação de leitura exercida preponderantemente pelo professor de Língua Portuguesa. No âmbito da escola, depreendemos dos relatos que incidiu apenas sobre o professor dessa disciplina a responsabilidade de desenvolver práticas de leitura entre os alunos. De fato, quando questionados sobre algum professor que os tenha incentivado a ler, alguns sujeitos não se lembraram de absolutamente nenhum. Mas aqueles que mencionaram algum se referiram, na imensa maioria dos casos, apenas aos professores do $1^{\circ}$. segmento do Ensino Fundamental ou a algum professor de Língua Portuguesa.

Os relatos dos sujeitos também apontaram que não houve projetos conjuntos, interdisciplinares, que estimulassem o desenvolvimento de práticas de leitura. Outro aspecto a ressaltar sobre a não atuação de professores de outras disciplinas é que alguns sujeitos explicitaram o caráter pouco interessante ou significativo de eventuais trabalhos de pesquisa realizados para a escola, que se resumiram a cópias mecânicas na biblioteca pública, trabalhos esses que não suscitaram retorno dos professores e comentários sobre a compreensão que os alunos tinham tido dos materiais lidos.

Entre os 8 sujeitos do grupo A, apenas 4 - André, Frida, Laís e Paula -, conviveram com outras pessoas no âmbito da escola, para além dos professores, que contribuíram para sua constituição como leitores. Tais pessoas foram seus colegas de escola, os quais recomendaram e compartilharam obras e ou com os quais se desenvolveu interlocução sobre leituras:

André: Então, na escola não tinha acesso, ganhava pouco e não tinha como comprar. Então, ficava à mercê de quem tinha algum livro para emprestar. [...] Aí, eu conheci um rapaz que estudou comigo, o nome dele era Alfredo Lima Rodrigues, que eu sempre tive contato com pessoas assim, de linhagem espiritual. Conheci o Lima e ele me deu um livro sobre gnose e eu li. Aí conheci o Albert, que era um africano que mora no Brasil, mas eu perdi contato com ele. E ele me deu alguma coisa sobre Vuduísmo, que é cultivado em certos lugares da África e tal. Aí, conheci esse cara e na escola. Todo mundo achava que ele era um nerd, porque ele sempre estava lendo e, um dia desses, ele estava lendo um livro sobre gnose. Aí eu falei: "Lendo um livro sobre gnose, difícil hein? Ele me falou: "Você conhece?" Eu disse: "Conheço". Aí ele falou: "É porque esses caras daqui, tá louco, hein? Eu falei: "Não, não é isso. É que você não conhece ninguém e acha que todo mundo é louco". Ele me perguntou se eu já tinha lido sobre 
gnose e eu disse: "Já". Aí a gente começou a conversar e ele me passou algumas coisas de mais linhagem espiritual. E aí eu li sobre o Comando do Pensamento, sobre Irmandade Rosa Cruz, sobre alguma coisa sobre o próprio candomblé, alguma coisa de quimbanda, umbanda, Zíbia Gasparetto. Ele me emprestou muita coisa sobre tarologia, numerologia, quiromancia. [...] Agora, tinham pessoas muito mais inteligentes do que eu na própria escola. O Luís mesmo era um cara que eu acho que conheci poucos que jogam xadrez tão bem quanto o Luís. Me ensinou a jogar xadrez quando eu tinha dez, dez anos de idade, mas ele já era um aluno CDF, ele lia, a mãe dele pegava muito no pé para ele ler, mas eram aquelas grandes obras: Machado de Assis, O Primo Basílio e era esses negócios

Paula: A partir da oitava série, eu comecei a gostar mesmo, a falar mesmo: "Nossa, que legal, vou para a escola". [...] Eu gostava de ir lá ver meus amigos, conversar. E até mesmo sobre livros, conversar com eles sobre livros. A gente pegava bastante e nós, assim... nosso grupinho pegava bastante livro para ler. Então, a gente gostava mesmo de ir para estudar e pra conversar com nossos amigos. [...] A gente pegava os livros, depois nós lia e depois sentava e ficava falando do livro, que era muito bom, para eles lerem... [Fora essa professora de português e minha mãe] Eu acho que [o contato com leitores foi] mais esses meus amigos de sala mesmo.

Frida: Os amigos, eu também não tive amigos e colegas que não gostavam de ler. Minhas amizades eram sempre as que gostavam de ler, não ficar se envolvendo talvez... porque tem muitos que se envolvem coisas que prejudicam, drogas, álcool, você entendeu? Essas coisas, crime... E a maioria dos meus amigos não eram muito assim. Eram mais de ir para a escola, querer trabalhar, querer ajudar a família, então, foram pessoas importantes.

Laís: Porque às vezes as pessoas pensam que a gente, mesmo não tendo uma condição de vida boa, o aluno, ele não tenta fazer por onde. E outras pessoas que eu conversava elas estudavam muito, pegavam livro, a gente às vezes trocava figurinha entre a gente sobre o que a gente aprendia mesmo em sala de aula. [...] Certas partes tem certos amigos que influenciam na leitura, né. Eu tinha uma colega que ela gostava de ler e ela pediu um livro emprestado sobre a Anita Garibaldi. E que era uma história que eu tinha em casa e aí eu falei para ela que a história era muito legal e contei. E quando eu leio algo, eu tenho que contar, não dá para ficar tudo para mim, não dá para ficar também, né.

Um aspecto importante a ressaltar quanto aos colegas leitores é que eles tinham aproximadamente a mesma idade dos sujeitos e, à exceção talvez de Luís, o amigo de André, não eram leitores mais experientes, ou seja, não tinham realizado muito mais leituras que os sujeitos. Eles constituíram interlocutores importantes, mas não foram representantes da cultura tipicamente letrada.

No âmbito da escola, houve também uma espécie de encorajamento mais difuso da leitura, que diz respeito ao status positivo de que os sujeitos gozavam entre seus amigos por serem leitores:

\footnotetext{
André: É que, quando nessa época que eu lia muito, o que acontece? Parece que é um ato que eu perdi, mas, quando você começa a ler muito, estimula muito seu cérebro e você começa até a pensar muito mais rápido. As suas células pensam mais rápido. Então, o que acontecia? Eu era um cara que na época trabalhava e, então, eu tinha acesso, podia comprar meus livros na época e também podia comprar minhas roupas. Então, eu era um cara popular, andava bem arrumado. [...] E era bom aluno. O pessoal falava: "Não, o Andrezão é o... Temos que fazer trabalho, vamos fazer com o Andrezão". Então, eu dizia: "Não, é nós. Relaxa". Então, eles vinham com certo respeito. Porque eles pensavam: "Não, o cara lê, mas o cara é popular, é amigo, fala com a gente, zoa, mas ele tem um QI acima”, vamos dizer assim, "ele é inteligente".
} 
A partir dos depoimentos coletados, é possível dizer que o livro didático de Língua Portuguesa contribuiu pouco ou nada para a formação de 7 dos 8 sujeitos do grupo A: AK47, André, Dandara, Frida, Laís, Marley e Paula. Tal resultado tão negativo pode ter sido influenciado também pelo fato de muitos sujeitos não terem chegado a usar livros didáticos durante longos períodos da trajetória escolar. Essa não utilização ficou evidente quando os eles aludiram às atividades de "tirar matéria" de livros didáticos na biblioteca escolar, às cópias da lousa por anos a fio e até ao fato de terem seu aproveitamento comprometido por falta do livro:

\begin{abstract}
AK47: Eu repeti quando eu mudei para cá, para a Cidade Tiradentes porque, quando eu cheguei aqui, eu estranhei um pouco, não sei o porquê, mas a professora tinha a prática de mandar a gente comprar livro. Livro que ela usava era tudo comprado. [...] E como em casa a gente nunca teve dinheiro para comprar livro, para nada, às vezes, eu ficava excluído das aulas dela. Porque eu não tinha o livro, sentava com alguém um dia, sentava com alguém outro dia. Isso me afastou bastante.
\end{abstract}

Apenas Maria aludiu a um aspecto positivo relacionado ao livro didático, o qual ela utilizou no Ensino Médio, numa escola mais central. A partir da leitura de trechos de obras nesse material, a pesquisada interessou-se por ler livros de dois autores:

\begin{abstract}
Maria Tinha um livro de português, que trazia uns pedaços de... não sei se eram contos, se eram versos. Eu lembro que eu peguei um livro, aquele Espumas Flutuantes, do Castro Alves, a partir de um livro didático. E tiveram outros também do Álvares de Azevedo, que bastante também a partir do livro didático. Tiveram sim, mas é... Alguns poucos, mas tinha. Tinha um livro que eu tenho até hoje, um de português. Eu achava o livro didático com um uso também. Eu achava ele bem legal, mas eu acredito que eu tinha esse interesse mais porque a questão do vestibular já estava assim em pauta na minha vida. Então, ficava mais... Até gostava no começo. Depois, eu não gostava muito não desses livros. Mas, no início, até gostava. [Hoje] não, não [me interesso muito por ler literatura brasileira]... Eu gosto de ler, mas assim, períodos que os autores viveram, pra quê aquele autor escreveu. Então, eu não leio necessariamente as obras, mas eu me interesso de ler, por que é considerado clássico, por que escreveu sobre que ponto de vista, usando que tipo de linguagem. Mais eu gosto de saber mais o contexto, do que propriamente ler os livros...
\end{abstract}

Um dos 7 sujeitos para os quais a mediação do livro didático de Língua Portuguesa inexistiu, foi pouco significativa ou mesmo negativa, verbalizou críticas a ele, dentre as quais estão a distância entre as narrativas do livro e a realidade do sujeito, o fato de essas narrativas não estimularem a reflexão ou a busca de conhecimento, e a expectativa de que os alunos dominem a norma culta:

AK47: Então, os livros didáticos todos, sem exceção, são um lixo, todos os livros didáticos. Eu lembro que livro didático da Língua Portuguesa tem aquele texto, a maioria da Ruth Rocha. Acho que não tem ninguém que não tenha lido Ruth Rocha, que vem sempre no livro didático e vem sempre uma historinha, traz um fato de um adolescente. Traz alguma coisa que não ajuda, não incentiva a mente e traz algumas histórias que não têm nada a ver com a gente, histórias inventadas a maioria, são criadas e que não têm nada a ver com a nossa condição de vida e não estimula a reflexão, o pensamento. Não estimula a criança a buscar, a ir atrás do saber e do conhecimento. Os livros didáticos são todos fracos 
na Língua Portuguesa. Traz uns poemas que você às vezes nem entende o poema, de tão abstrato que ele é. Você não consegue entender. E a linguagem... Eu acho que o livro didático para criança e adolescente não pode ser uma linguagem que a gente não está habituado, uma linguagem muito culta como chamam.

As críticas de AK47 estão em consonância com as dificuldades apontadas por vários sujeitos quanto à leitura de obras da literatura brasileira: a não identificação com a temática das obras e as dificuldades de compreensão da linguagem. Aqui cabe um questionamento sobre se as críticas ao livro devem ser imputadas apenas a ele e uma reflexão sobre o uso que a escola fez de tal material. A fala do sujeito novamente evidencia as dificuldades dessa instituição no cumprimento de seu papel de "descolamento" do cotidiano e da realidade imediata do aluno, de apresentação da temática dos textos, de ampliação de vocabulário e de auxílio à compreensão do registro culto da linguagem.

O fato de não se realizar tal trabalho não parece ter sido uma opção adotada em nome da diversidade cultural ou da não adesão a um suposto preconceito lingüístico, mas sim uma omissão, omissão essa que pode ter prejudicado as competências leitoras do sujeito, e também uma possível continuidade de sua escolarização ${ }^{90}$.

Em síntese, para a grande maioria dos sujeitos do grupo A, estar na escola não foi sinônimo de desenvolver práticas de leitura, seja porque elas não foram propostas, seja porque foram mediadas de maneira equivocada durante a maior parte da trajetória escolar dos pesquisados. Muitas vezes, a escola exerceu um papel diametralmente oposto ao que se espera dela, impondo as mais variadas barreiras de acesso ao material impresso, à formação leitura e à própria escolarização. A responsabilidade pelo desenvolvimento de práticas de leitura recaiu exclusivamente sobre o professor de Língua Portuguesa. A mediação pelo livro didático de Língua Portuguesa - mal utilizado ou de acesso não franqueado ao aluno - foi insignificante ou negativa para a imensa maioria. Em tal contexto, ter chegado a se constituir leitor, ainda que não leitor de literatura brasileira, foi algo bastante improvável, que só se compreende analisando a configuração de mediadores em vários âmbitos para além da escola.

\footnotetext{
90 O aproveitamento de AK47 no primeiro ano de seu curso de graduação em Ciências Humanas numa conceituada universidade privada de São Paulo foi muito comprometido, devido a dificuldades de compreensão dos textos. Suas notas poderiam ter inviabilizado a continuidade de sua bolsa e sua permanência naquela instituição. Tal quadro foi revertido graças à atuação voluntária de uma docente, que auxiliou o aluno fora do horário de aula.
} 


\subsubsection{A mediação de leitura na escola - Grupo B (os leitores de literatura)}

Depreende-se dos relados dos sujeitos do grupo B que eles desenvolveram mais práticas de leitura no âmbito da escola do que os pesquisados do grupo A. Três dos cinco estiveram envolvidos em atividades de leitura desde o primeiro segmento do Ensino Fundamental, e todos o estiveram no segundo segmento do Ensino Fundamental e no Ensino Médio. Ainda que a atuação da escola na mediação da leitura mereça muitas críticas dos sujeitos do grupo B, temos a impressão de que a escola por eles freqüentada foi de qualidade menos baixa que a dos sujeitos do grupo A.

Assim como ocorreu no grupo A, no grupo B, a responsabilidade pela formação leitora incidiu majoritariamente sobre o professor de Língua Portuguesa e o professor de Ensino Fundamental. Neste grupo, a mediação do livro didático foi positiva para 4 dos sujeitos. Um aspecto importante no grupo $\mathrm{B}$, para 3 sujeitos, foi a mediação de leitura para além da escolarização básica, em especial, os cursos pré-vestibulares comunitários para 2 sujeitos e a graduação em Letras para um terceiro.

O fato de os sujeitos do grupo B terem estado envolvidos em muito mais práticas de leitura no âmbito da escola que aqueles do grupo A aparentemente esteve muito vinculado à localização das escolas freqüentadas pelos sujeitos em bairros menos periféricos que Cidade Tiradentes, tais como Jabaquara, Aricanduva e Tatuapé, Itaquera ou outra cidade da região metropolitana durante vários anos da escolarização básica. Parece também estar vinculada ao fato de 3 sujeitos terem tido os mesmos professores de Língua Portuguesa por períodos mais longos, de no mínimo 2 anos.

Mas afirmar que esses sujeitos estiveram envolvidos em mais práticas de leitura não significa dizer que não façam muitas ressalvas à atuação da escola que freqüentaram. As críticas feitas pelos sujeitos do grupo B guardam semelhanças com aquelas feitas pelos do grupo A. Referem-se a restrições de acesso à biblioteca escolar, inexistente, fechada ou que não permitia circulação do acervo em algum período da escolarização básica, no caso de 3 sujeitos (Álvares, Malik e Taiko), ou durante toda ela (Zapata), ao pouco incentivo à leitura (Álvares, Taiko, Zapata), à falta de mediadores de leitura na biblioteca, ao fato de os professores subestimarem a necessidade de leitura dos alunos (Álvares e Taiko), à baixa qualificação dos professores (Álvares e Zapata), à falta e ou à rotatividade de professores (Taiko), e até ao desestímulo à continuidade da escolarização por algum professor (Taiko), a apresentação da leitura como uma tarefa obrigatória: 


\begin{abstract}
Álvares: A primeira escola foi no Jabaquara, uma escola lá no Jabaquara, né, Fernando Neto, Salvador de Noia, Fernando Pessoa depois aqui na Cidade Tiradentes. E as escolas... a biblioteca sempre fechada, sem mediadores de conhecimento nas bibliotecas da escola, e quando era aberta não tinha ninguém para mediar conhecimento, os livros paradidáticos, os livros de literatura pouco específicos e as próprias professoras nunca incentivaram uma leitura, um livro, nunca falaram de nenhum livro... Eu li... Acho que a professora comentou sobre um livro e eu li porque eu quis, mas não valia nota (então, ninguém leu porque não valia nota e eu li, mas sem valer nota, tinha sempre essa questão de nota), o Meu pé de Laranja Lima.

$[\ldots]$

Porque eu acredito que possa ser que as pessoas não lêem porque não tem pessoa que fala que é agradável. [...] Que fale que é fácil. Ou que, mesmo que não seja fácil... Não, não foi fácil, mas eu fui lendo, lendo, lendo no Aurélio, no dicionário e aí fui aprendendo palavras novas. E o ser humano ele pensa e se expressa através das palavras. Quão maior o arcabouço, quanto maior o arcabouço de palavras, ele se expressa melhor e os seus pensamentos fluem melhor. E ali está seu raciocínio, porque o próprio idioma limita o pensamento porque não dá para você sentir uma coisa que não tem no seu idioma.
\end{abstract}

Taiko: Porque hoje a maioria das pessoas não gosta de ler por causa das pessoas que formam a escola. Agora, eu estou falando da escola. Na escola, os alunos não gostam de ler porque só são incentivados a ler por obrigação, não tem uma pessoa preparada para influenciar o aluno, sabe, de uma forma envolvente, daquilo que ele gosta. [...] E, quando a pessoa gosta, quando tem aqueles cinco, três, dois, ou um na escola que gosta de ler, eles proíbem. [...] E tem professores que não gostam que os alunos gostem de ler, tenham interesse, porque eles acham que ele é o professor e o aluno é o aluno e tem que ficar por ali, entendeu? Não pode seguir em frente, fazer uma carreira maior que a dele, ter uma profissão maior e ganhar melhor que ele. Eles não se satifaz com isso, tem muitos professores, tem uns que levantam os alunos e tem uns que abatem.

Zapata: Porque eu fiquei uma vez na chamada recuperação de literatura, porque eu não lia os livros. "Se não ler esse livro, não vai passar. Tem que apresentar o seminário". [...] Mas novamente eu, como futuro professor, acho que a escola tem o principal papel de formar um aluno não leitor porque "você vai ter uma prova dia vinte, lê porque você vai ter uma prova" e aí você começa a ler. Ao mesmo tempo que ele é muito bom, a narrativa é cansativa e você não está acostumado com isso e você começa a não querer ler, porque tem um monte de curso, um monte de coisas que competem, né. E aí o aluno acaba abandonando. Ela fala: é muito chato, eu não vou ler.

Álvares: Mas do outro lado tem a questão da falta de compromisso dos professores em virtude dos problemas sociais, de não pôr professores capacitados para aquilo, professores que já têm uma visão da sociedade e imprime na sua educação: "Ah, eles não vão precisar dessa leitura, eles não vão precisar ler isso".

A despeito de tais críticas, depreendemos dos relatos dos sujeitos que a escola a que tiveram acesso foi, por assim dizer, "menos pior" que aquela freqüentada pela maioria dos sujeitos do grupo A ou que eles parecem ter tido com ela e com o saber uma relação melhor, o que não significa dizer que gostassem da escola, mas apenas que se saíram melhor nela e conseguiram de alguma forma desenvolver um certo prazer de conhecer e de ler.

Se, no caso do grupo A, as barreiras à escolarização, à leitura e ao desenvolvimento de uma relação positiva com o saber podem ter comprometido o aproveitamento escolar e gerado um afastamento da leitura, no grupo B, embora tais barreiras ainda se tenham feito presentes, elas tiveram um impacto muito menos dramático no aproveitamento escolar dos sujeitos. De fato, uma característica comum a todos os sujeitos do grupo B é seu excelente aproveitamento escolar. Nenhum dos 5 sujeitos repetiu série alguma do Ensino Fundamental, à exceção de 
Beatriz, que cursou novamente a $2^{\mathrm{a}}$. série do Ensino Fundamental a despeito de ter sido aprovada, apenas porque sua mãe desejava que ela se mantivesse na mesma classe que sua irmã gêmea, Paula, que havia sido reprovada. Além disso, ao menos 3 sujeitos - Álvares, Malik e Taiko - descreveram-se como os melhores alunos de suas salas ou da escola toda desde o início do Fundamental. Os 2 outros sujeitos - Beatriz e Zapata - não apresentaram dificuldades de aprendizagem e também sempre tiveram bom desempenho. Isso, porém, não foi sinônimo de gostar da escola, no caso de Zapata.

A auto-imagem de excelente aluno aparentemente foi desenvolvida pelos sujeitos desde os primeiríssimos anos do Ensino Fundamental. Álvares, Taiko e Zapata, ao entrarem na escola, já tinham adiantado as aprendizagens em casa junto a sua família. Beatriz, por sua vez teve como professora da $1^{\mathrm{a}}$. série do Fundamental a sua tia, o que reduziu enormemente seu temor inicial da escola:

\begin{abstract}
Álvares: Eu entrei na escola um ano mais cedo e eu fui alfabetizado antes de entrar na escola, em casa, pelo meu pai e pela minha mãe. E nisso que eu fui alfabetizado, na primeira série, eu alfabetizei minha irmã. [...] Eu era o mais adiantado e ainda fiquei em casa um mês. Aí fiquei lendo Caminho Suave.

Zapata: Então, na segunda série, nada era novidade. Não é que eu tinha visto geral [com os meus irmãos], mas você saber ler e escrever já era suficiente. [...] Modéstia à parte, gostar de escola, como eu falei, eu nunca gostei. Eu estudava obrigado porque eu entendia a importância da escola. Agora, gostar... eu acordava cedo e, se eu pudesse, eu não ia mesmo. Mas sempre nós [meus irmãos e eu] fomos bons alunos.
\end{abstract}

Malik, que, ao contrário dos outros 4 sujeitos, não pôde contar com o capital escolar dos pais, dos irmãos ou de tios, desenvolveu desde os primeiros dias de sua escolarização uma relação muito positiva com o saber e a leitura. O sujeito relatou em detalhes, como se visualizasse a cena de um filme, os elogios que recebeu logo na $1^{\mathrm{a}}$. série e a exibição pública de sua habilidade de leitura por toda escola e sua transferência para a melhor sala, o que provavelmente contribuiu para que ele começasse a se perceber como leitor e excelente aluno:

Malik: Olha, o meu caso foi bem interessante, eu me lembro de toda cena [de quando eu comecei a ler]. Eu li uma frase que dizia: "Ele estava na praça". Eu li isso no primeiro mês, no primeiro bimestre do primeiro ano e aí a professora Dora me empurrou por todas as salas, da primeira até quarta, para eu ler na frente da classe para mostrar que eu sabia ler. [...] Na verdade, a gente estava fazendo uma atividade, era a lição do R, lembro até hoje, era a lição do R. E aí tinha um menino que lia "é toulo, é toulo". E eu falei: "é touro, é touro". E aí eu peguei o livro e li a frase inteira. Daí a professora viu que a gente estava conversando. Primeiro, ela queria dar uma "carcada". E aí eu li, ela disse: "Lê de novo". E aí eu li. Então, ela falou: "Vem aqui". E ela passou em todas as salas - era no período vespertino - correndo por todas as salas, mostrando que eu sabia ler. [...] Eu tinha seis [anos] ainda. Eu entrei na escola um pouco adiantado, porque eu fazia sete em julho. No primeiro momento assim, eu disse: "Caramba, eu sei ler". [...] Acho que [quando a Dona Dora me levou em todas as salas pra me exibir eu fiquei] mais encabulado do que com orgulho assim, mais encabulado. Era meio embaçado ficar lendo para a sala inteira e eu era, ainda tinha aquela categorização A, B, C e D, e eu era da D... [Eu tinha sido colocado 
na D] provavelmente porque a nossa turma veio, eu tenho quase certeza que eles faziam a distinção pelo poder sócio-econômico, porque era um bairro pobre, mas umas áreas em torno eram mais qualificadas.

$\mathrm{Na} 2^{\mathrm{a}}$. e $3^{\mathrm{a}}$. séries do Fundamental, a rotina de elogios se manteve. A professora de Malik, que foi a mesma nas duas séries, além de incentivá-lo e dar-lhe até presentes, manteve o interesse de seu aluno por estudar propondo-lhe desafios de aprendizagem, no que lembraria, na perspectiva de Vygotsky, a prática de incidir sobre a zona de desenvolvimento proximal da criança:

Malik: Lembro até hoje de vários casos de ser aplaudido. No segundo ano, a professora chamava Geórgia, de Língua Portuguesa e eles percebiam a dificuldade financeira da minha família. Tinha uma moça que era servente da escola, que era parente do meu pai, daí, eu não ia para excursão, não ia para nada. Só que aí a professora começou a bancar e um dia ela chegou para mim... A Geórgia falou assim: "Para o melhor aluno do Brigadeiro Correa de Mello", que era a escola que eu estudava, "você está recebendo um prêmio". E ela me deu um uniforme novo. Isso, no segundo ano do fundamental lá atrás voltando essa história, porque da Geórgia eu tinha mais recordação do que da Dora, porque ela me empurrava, me incentivava muito. [...] O que ela mais me incentiva era quando ela chegava e começava a cutucar, ela jogava um livro na mão e dizia: "Você já leu isso aqui?". Mas era tudo livro didático. Ela dizia: "Lê esse texto, você já pode ler esse aqui". E daí ela passava lição de caligrafia e aí ela falava: "Não, você não precisa fazer, lê isso aqui". Aí, eu ia ler outra coisa. Ela passava texto maior para eu ler. Ela não falava na frente de todo mundo, era bem na surdina, ali. Na frente de todo mundo, foi quando ela me deu esse uniforme. Eu tenho essa imagem todinha: dia chuvoso, a gente fazendo o texto "A Raposa e as Uvas", aquela história jargão e ela chegou assim e parou a sala. E aí fez todo mundo me aplaudir e eu fiquei morrendo de vergonha. Eu falava: "Pára com isso!". Mas aí eu ganhei esse uniforme porque eu não tinha uniforme. Eram muitos irmãos. [...] $\mathrm{Na}$ escola, naquela época, eram quatro e uma no pré. Então, não dava para garantir material para todo mundo e também tinha um livro. [...] Essa Garé foi minha professora no segundo e terceiro ano e tinha um livro que chamava Caminhando, eu e meu irmão dividíamos o livro. Nós estávamos na mesma série, já na terceira série, e a Geórgia ainda estava comigo. E um dia era para mim e outro dia era para o Sidney, até que a Garé me deu o livro. [...] E aí ela me deu o livro, essa Geórgia. Eu tenho saudades dela de vez em quando. Ela, acho que nem vai lembrar de mim, talvez lembre. Daí, ela me deu esse livro no terceiro ano. Nossa, dá para lembrar de todas as professoras, porque esse destaque que eu tinha na sala de aula repercutia com as professoras, assim.

A auto-imagem de excelente aluno foi mais uma vez alimentada na escola, desta vez pela professora de Geografia da 5a . série. Malik voltou a ser elogiado e aplaudido em público por seu desempenho:

Malik: No terceiro bimestre... [a professora de Geografia] já estava dizendo os que não iam mais precisar fazer avaliação no último bimestre porque já tinham sido aprovados. Foi no ano que trocou as notas para: B (bom), NS(não satisfatório) e S (satisfatório) e aí ela falava: "Você já vai ficar com B (bom), não precisa fazer". Eu e mais uns três alunos. Daí, ela passou uma redação de tema livre. Daí, eu escolhi "Países ricos e países pobres". Aí é que eu descobri que eu devia ser militante, porque ela passou esse texto e eu entreguei o texto normal, uma redação normal, mas quando veio a correção ela disse: "Aqui tem um aluno que está na quinta série, mas fez uma redação de sétima série". Daí, eu lembro de um carinha muito chato, o nome dele era Clayton, outro Clayton, era muito chato, como eu detestava aquele moleque porque ele era muito chato. E ele disse: "Ah, esse menino tem que ir para a sétima série, ele pode até ser professor se está tão adiantado assim". E eu, nem aí. Aí, quando ela falou: "Eu quero que todo mundo aplauda o Malik". Nossa, aí o mundo caiu, porque ela fez eu ler a redação para todo mundo e perguntou, fez a mesma pergunta que você: "Onde você tirou essa informação?". E eu não sabia de onde eu tinha tirado essa informação de que os países do Primeiro Mundo, foi isso que 
eu escrevi na redação: "Os países do Primeiro Mundo não colaboravam com os países do Terceiro Mundo" e exemplifiquei Brasil e Argentina. Os Países do Segundo Mundo estão com muitos problemas, provavelmente identifico uma União Soviética, olha nada a ver, que viagem. [risos] Isso no ano de 1992, e falei alguma coisa sobre a época e ela fez a sala toda me aplaudir e isso aí me marcou bastante.

Zapata, que contava com ajuda dos irmãos mais velhos e que se ressente hoje do fato de a escola como um todo ter sido pouco desafiadora e a aprendizagem, pouco significativa e baseada em memorização, a exemplo de Malik, mencionou alguns professores comprometidos e exigentes, que foram importantes para sua formação. Dentre eles, citou em especial a professora da segunda série do Ensino Fundamental, que evitou também uma possível evasão escolar, viabilizou sua permanência na escola e contribuiu para suas aprendizagens fornecendo-lhe material escolar:

Zapata: Nossa, [eu me lembro de] vários [professores]. Inclusive a minha professora da segunda série, eu queria encontrar ela hoje, mas ela já não deve estar viva. Na época, eu tinha um ódio dessa mulher, professora Ana era o nome dela, mas ela já era uma senhora. Mas hoje, pensando um pouco o que é um professor, eu queria encontrar ela para agradecer uma porção de coisas. [...]Porque ela era muito chata, ela pegava muito no nosso pé. Porque a gente era uma família, imagine, um monte de crianças e minha mãe trabalhava. E, como eu falei, como a gente não gostava muito de escola, tinha dia que a gente não ia, minha mãe não sabia e não sabe até hoje. Inclusive na faculdade, eu me ferro um pouco por isso, porque a gente sempre se defende, se garante naquilo que você sabe. Então, na segunda série, nada era novidade. Não é que eu tinha visto geral [com os meus irmãos], mas você saber ler e escrever já era suficiente. E assim, não ia muito para a escola. Não é que não ia muito. Na segunda série, eu cheguei a faltar bastante. Só tinha esse tal de A, que não serve para nada, e essa professora enchia muito nosso saco. E nessa época, era uma época que a escola não tinha livro e o livro era a maior nota, essa professora dava livro para a gente, ela comprava os livros, comprava caderno. A cartilha, né. E plástico, sabe aquele plástico azul? Aquele, sabe, que cobria a carteira. Aquela coisa ridícula. Então, o que eu falo dessa professora é isso: queria encontrar e, como eu acredito em reencarnação [em tom irônico], quem sabe, eu encontro para agradecer algumas coisas. Ela era boa mesmo, mas era chata, pegava no nosso pé. Ela pegava no pé porque a gente faltava. Não era por questões, assim. Ela era um pouco dura, não é dura, é uma pessoa que eu, o Malik, a Maria faríamos o mesmo para qualquer um de nós sabe, ficar. [...] Lembro dos bons [professores], porque a maioria não serve para nada, mas eu lembro de um monte. Assim, da quinta série para frente, só foi o de História. Daí para a frente, os professores, eu gostava de quase todos e tinha o professor João. Acho porque eu gostava de História também. Mas teve o de Matemática também, o João, que era outro pé no saco, mas que era um bom professor, o professor de Português.

No $1^{\text {o }}$. segmento do Ensino Fundamental, 3 dos 5 sujeitos do grupo B - Álvares, Malik e Taiko - desenvolveram práticas de leitura no âmbito da escola. Álvares lembra-se de ter lido preponderantemente livros didáticos, enquanto Malik e Taiko leram também literatura infantil. Álvares relatou ter lido tais materiais mais por iniciativa própria do que por incentivo da escola:

Álvares: Aí, eu pegava os livros da escola. Eu estava na terceira série, eu pegava livros da quinta, sexta, sétima série para eu ver o que ia ter depois. Eu sempre pegava livros assim, estava na quarta, pegava da quinta, assim... [Eu pegava] na biblioteca da escola os livros paradidáticos. Eu tinha acesso a livros paradidáticos, mais paradidáticos. 
Aparentemente Malik foi o único sujeito que freqüentou a biblioteca escolar para ler literatura infantil e juvenil por iniciativa da escola. O sujeito não soube precisar a frequiência de tal atividade. Mas lembrou que não havia qualquer indicação de obras ou proposta de atividades de leitura naquele ambiente nem pela professora nem pelo atendente da biblioteca, o que levava a maioria dos alunos a simplesmente não ler nada. Ainda assim, Malik leu com grande interesse e prazer várias obras de literatura infantil e juvenil até o final da $5^{\mathrm{a}}$. série, ocasião em que sua família se mudou para Cidade Tiradentes. O sujeito ainda se recorda de vários títulos que leu:

\begin{abstract}
Malik: Ia com a professora [à sala de leitura]. Não levava livro para casa. A professora levava a galera e ficava um monte de gente e aí não tinha leitura nenhuma. Ela dizia: "Você vai lá e pega o que você quer". Tinha acho que um dia específico para ir para a leitura. Não me recordo bem das ocasiões que nós íamos para a sala de leitura, mas não havia cobrança de alguma forma de avaliação da leitura. A gente ia lá para... Mas não havia indicação de leitura mesmo, que te indicasse para algum caminho. Então, eu lembro logo de cara, assim, era na terceira série que eu freqüentava a sala de leitura, de: Mobi Dick era o livro que eu li. Não era da Coleção Vaga-lume, mas era parecido... [Era] literatura infantojuvenil com títulos clássicos. Títulos para os da minha época assim: Passageiros do Futuro, A Ilha Perdida, A Primeira Reportagem, esses os livros que eu li. Açúcar Amargo, um clássico que até hoje na faculdade, eu reli esse livro porque ele é muito legalzinho. Acho que essa coleção iniciou uma boa parte de quem lê um pouquinho, começou com essa Coleção Vaga-lume... [Eu li a Coleção Vaga-lume] da terceira série até a sexta, sétima. Até a sétima série mais ou menos. Tinha uns dez anos...
\end{abstract}

Imagino que um dos fatores que levaram Malik a ler e a freqüentar a biblioteca escolar mesmo não havendo instruções sobre o que ler ou atividades de incentivo à leitura naquele espaço tenha sido a relação muito positiva que o sujeito desenvolveu com o saber e com a leitura desde a alfabetização.

Taiko cursou o $1^{\circ}$. segmento do Ensino Fundamental numa escola confessional em Salvador, na qual tinha uma bolsa. A pesquisada não freqüentou a biblioteca escolar, que não existia naquela instituição, mas aparentemente esteve envolvida em práticas de leitura de literatura infantil. Ela lembra-se de gostar daquela escola e de ter lido com prazer livros de Ruth Rocha, um dos quais foi adquirido por seus pais a pedido dos professores:

Taiko: Na escola, eu lia - que até hoje fica na memória - de Ruth Rocha, livros de Ruth Rocha, se eu não me engano era de um Marcelo, que estava aprendendo a ler as horas. [...] Não sei [o título dos livros], eu sei que tem Marcelo no título e é da Ruth Rocha. Eu li esse livro, foi tudo de bom. [...] Isso, [o livro era da] escola e os professores exigiram que comprasse para o nosso crescimento.

Beatriz não se recordou de propostas de leitura no âmbito da escola. Se elas existiram, dada a profusão de práticas e de incentivo em sua família, tais atividades não foram marcantes. Beatriz não freqüentou a biblioteca escolar. Ao invés disso, foi à biblioteca pública com as irmãs. A respeito da escola, considera que ela lhe deu pouco incentivo à leitura: 
Beatriz: [Eu acho que a escola me incentivou a ler] um pouco.

Um quinto sujeito - Zapata - lembrou-se de ter brincado de ler as narrativas curtas da cartilha em casa, com os irmãos, mas não relatou ter desenvolvido muitas práticas de leitura na escola no $1^{\circ}$. segmento do Fundamental. Também não teve acesso à biblioteca escolar, inexistente em todos os estabelecimentos em que estudou.

Depreende-se dos depoimentos dos sujeitos que a concepção de leitura hegemônica na escola no $1^{\circ}$. segmento do Ensino Fundamental tenha sido leitura para a escolarização. Álvares fez referência ainda à idéia de leitura como algo desnecessário:

Taiko: E os professores exigiram que comprasse [o livro de literatura infantil] para o nosso crescimento.

Álvares: Tem a questão da falta de compromisso dos professores em virtude dos problemas sociais, de não pôr professores capacitados para aquilo, professores que já têm uma visão da sociedade e imprime na sua educação: "Ah, eles não vão precisar dessa leitura, eles não vão precisar ler isso".

No $2^{\circ}$. segmento do Ensino Fundamental, ao contrário do que aconteceu no grupo A, foram propostas leituras a todos os sujeitos. No entanto, 4 dos 5 pesquisados do grupo B Álvares, Malik, Taiko e Zapata - acreditam que a frequiência e a mediação das práticas de leitura no âmbito da escola nesse período ficaram aquém do ideal. Álvares novamente atribuiu a sua própria iniciativa o fato de ler muito e não ao trabalho da escola com a leitura:

\footnotetext{
Álvares: Então, algumas professoras falavam sobre os livros. Mas só que eu quis buscá-los porque eu acreditava que também ia me deixar em condições de eu ser um ser humano melhor, de estar numa sociedade, de conversar com as pessoas, que eu adoro conversar porque, para mim, ser ignorante era ser era uma pessoa que você não tem direito de falar.
}

Malik lembrou-se de ter lido apenas 3 livros entre a $6^{a}$. e a $8^{a}$. séries, período em que estudou numa escola em Cidade Tiradentes. Apesar de haver indicações de leituras, o sujeito não pôde realizar todas, por barreiras de acesso aos livros - a nova escola não tinha biblioteca escolar e ele não dispunha de recursos para comprar as obras -, o que foi motivo de grande frustração:

Malik: Lembrei de uma outra história de leitura na minha vida. Tínhamos que ler $O$ Menino do Dedo Verde e eu não tinha dinheiro para ler e eu não li o livro e fiquei com nota baixa. Isso aí me marcou bastante. Eu gostava de ler e não tinha grana para comprar o livro... Talvez inconscientemente [eu tenha ficado com mais vontade ainda de ler]. Mas aí é uma história que eu lembro, porque eram duas formas de leitura: a peça que nós fomos assistir e a outra, o livro. A minha leitura foi só a partir da peça. Então, minha nota foi reduzida. Eu fiquei com nota baixa. 
As aulas de Língua Portuguesa podiam ser bastante tediosas porque havia muitas cópias da lousa, motivadas em parte pela falta de livro didático. Ainda assim, a relação de Malik com a professora de tal disciplina - a mesma durante esses três anos - foi revestida de grande afetividade. O sujeito recordou-se com nostalgia da professora pela qual alimentou uma paixão:

\begin{abstract}
Malik: Eu lembro da professora Lúcia, que inclusive eu fui apaixonado por ela. Não vai entrar na pesquisa mesmo, então, eu brinco. Eu fui apaixonado pela professora Lúcia. Ela tinha uns trinta e poucos anos e eu me apaixonei por ela. [Ela] era [professora] de Português, e eu achava... Mas ela era uma ótima professora e ela indicava livros na sala de aula. Ela indicava, mas a gente não tinha acesso e sem muita possibilidade de conseguir livro. Eu acho que foi um período de ostracismo da sexta série até o primeiro ano colegial. Sem leitura, se eu contar, acho que li uns três livros, da sexta série até o colegial, foi muito. Muito pouco.
\end{abstract}

A trajetória escolar de Malik parece muito marcada pelos elogios e alguns gestos de algumas professoras, os quais assumiram grande importância. Não por acaso Malik foi o único sujeito que afirmou "ter saudades" de uma professora e que declarou abertamente sua paixão por duas outras. Temos a impressão de que, para ele, ter um excelente desempenho escolar e ser considerado o melhor aluno pelas professoras foi ainda mais relevante do que para outros sujeitos também bons alunos:

\begin{abstract}
Malik: E aí ela me deu o livro, essa Geórgia. Eu tenho saudades dela de vez em quando. Ela acho que nem vai lembrar de mim, talvez lembre. Daí ela me deu esse livro no terceiro ano. Nossa, dá para lembrar de todas as professoras, porque esse destaque que eu tinha na sala de aula repercutia com as professoras assim [...] Teve uma professora de Geografia da quinta série [que me marcou positivamente]. O pior é que eu não vou lembrar o nome dela. Nossa, eu também era apaixonado por ela. $\mathrm{Na}$ verdade, não era apaixonado por ela não. Mas eu achava ela muito bonita. [...] Eu lembro da professora Luísa, que inclusive eu fui apaixonado por ela.
\end{abstract}

Dada a importância que Malik atribuía à repercussão de seu aproveitamento junto aos professores, o fato de não poder ler livros da $6^{\mathrm{a}}$. à $8^{\mathrm{a}}$. séries e ter suas notas excelentes reduzidas talvez tenha aumentado ainda mais sua avidez por leitura. A partir dos 14 anos, quando se inseriu no mercado de trabalho e teve acesso a mais material impresso, o sujeito aproveitou todas as oportunidades de leitura que surgiram no ambiente de trabalho e na escola.

Taiko diz ter desenvolvido muito mais práticas de leitura - cerca de um livro por dia do que aquelas propostas pela escola e, de certo modo, a despeito desta. Afinal, a instituição impôs-lhe uma barreira de acesso aos livros, que a jovem Taiko conseguiu derrubar temporariamente com sua assertividade e insistência: 
Taiko: E, quando a pessoa gosta [de ler], quando tem aqueles cinco, três, dois, ou um na escola que gosta de ler, eles proíbem. Eles... No meu caso, eu gostava de levar livros, bastantes livros para eu ler, eu devorava um livro em um dia, bastante livro, eu gostava, e entregava e pegava mais. Uma fome insaciável de ler livros. Aí, elas não gostavam que eu pegava. Foi uma luta, porque elas falavam assim, "Não podemos mais emprestar livros porque os alunos do ano passado, retrasado, não trouxeram os livros para cá, emprestaram e não devolveram”. Então, elas achavam que eu tinha o mesmo caráter que as outras pessoas, mas eu mostrava diferente pra elas, entendeu? Aí, teve uma hora que isso acabou. Aí, elas aprenderam a gostar de mim, a me emprestar os livros e tudo ficou numa boa. Mas agora eu não pego mais livros emprestados lá, porque está fechada, nem a minha irmã mesmo pega. [Isso na escola que eu] estudava [no $2^{\circ}$. segmento do fundamental].

Nesse contexto tão desfavorável à leitura, Taiko pontuou que apreciou o trabalho realizado por uma professora comprometida e exigente que teve na $8^{\mathrm{a}}$. série:

Taiko: Eu lembro que tinha uma professora no Salgado na oitava série que se chamava Célia... [Ela dava aula] de Português. Ela era uma ótima professora, até a gente começou a estudar o Auto da Barca do Inferno. Até hoje eu lembro desse livro e pretendo lê-lo novamente. [...] Eu não lembro o que me marcou, mas marcou a minha vida. Ela era uma ótima professora. [O que ela fez de diferente é que] ela vinha, perguntava as nossas dúvidas. Como eu disse, eu sou muito curiosa. Mesmo as perguntas que eu acho que são desnecessárias, mas tenho aquilo comigo, eu solto. Acho que, por mais que as pessoas achem que sejam fúteis as suas perguntas, você tem que dizer, porque a sua pergunta pode não ter valor para umas pessoas, mas para outras pode ter valor, pode ter algum fundamento, entendeu? Aí, eu falava, ela vinha, me explicava, me dizia tudo. Ela era super legal, tanto que ela era humilhada por alguns alunos. Então, eu tinha aquele amor por ela, entendeu, porque eu achava injusto o modo como meus colegas tratavam a professora, porque ela se interessava, preparava a aula, a matéria, com um interesse especial para nos ajudar. E os alunos não queriam, mas eu reconhecia o esforço dela.

Vale dizer que as estratégias didáticas da referida professora nada tiveram de extraordinário. Consistiram de aulas expositivas, solução de dúvidas e demonstração de interesse pelos alunos. É digno de nota que, submetida que estava a um alto rodízio de professores e a muitas aulas com eventuais, Taiko tenha avaliado como uma qualidade importante da docente o fato de ela preparar aula.

Zapata realizou poucas das leituras propostas pela escola no $2^{\circ}$. segmento do Ensino Fundamental. Não utilizou livros didáticos de Língua Portuguesa. Ao invés disso, ia à biblioteca pública "tirar matéria". Eventuais leituras propostas na escola não puderam ser realizadas porque as escolas não dispunham de biblioteca e o sujeito não podia adquirir os livros. Nesse contexto, ele só leu literatura juvenil depois de adulto:

Zapata: Era biblioteca. Lembra das bibliotecas que eu ia lá? Então, não tinha livro didático e os demais [livros] a gente tinha que comprar. E, como eu não comprava,... [não lia].

No grupo B, Beatriz foi a única leitora que não fez críticas às práticas de leitura no âmbito da escola e sua freqüência durante o $2^{\circ}$. segmento do Fundamental. Da $5^{\mathrm{a}}$ à $8^{\mathrm{a}}$ série, a pesquisada teve a mesma professora de Língua Portuguesa, a qual foi modelo de leitora, verbalizou constantemente incentivos à leitura, em especial de literatura juvenil e a frequiência 
à biblioteca, que permanecia aberta mesmo nas férias e cujo acervo era circulante. A professora estabeleceu uma interlocução informal na biblioteca, fora do horário de aulas, sobre as leituras dos alunos, acatando eventuais sugestões de leitura desses, no que lembrava a dinâmica de um clube de leitores:

Beatriz: Ela [a professora de Língua Portuguesa] ajudou [a me fazer gostar de ler]. Ela dava as dicas e tinha os meus amigos que eram os mesmos amigos da Paula, já que a gente estudou sempre na mesma sala. Nossos amigos sempre gostaram de ler. E aí a gente ia na biblioteca junto, a gente pegava o livro, a gente encontrava com a professora Gisele. Às vezes, a gente não tinha aula com ela naquele dia, mas a gente encontrava com ela lá na biblioteca. E ela perguntava que livro a gente tava lendo, se era bom, se a gente tava gostando. Perguntava do que falava o livro. Ela sempre ajudou a gente, a professora Gisele. [A gente] ia sempre na hora do nosso intervalo, porque no horário de aula a gente não podia ficar indo na biblioteca, mas no intervalo, juntava o nosso grupinho e já ia pra biblioteca pegar livro.

No Ensino Médio, foram desenvolvidas práticas de leitura no âmbito da escola por todos os sujeitos. No entanto, a freqüência delas novamente pareceu insuficiente a 4 dos 5 pesquisados deste grupo - Álvares, Malik, Taiko e Zapata.

Três sujeitos - Álvares, Malik e Zapata - não freqüentaram a biblioteca escolar ou porque ela inexistia ou porque estava sempre fechada. A fala da pesquisada Taiko, que estudou em escolas com biblioteca, denunciou a terrível barreira de acesso ao acervo que ela novamente teve de vencer no Ensino Médio:

Taiko: Na [escola] que eu estudo agora, também tinha esse mesmo problema [de não empréstimo de livros]. Os alunos da minha sala não podiam pegar [livros], não sei o porquê, acho que por causa do mesmo motivo. Por causa de um, todos sofrem. Aí, eu fui lá, comecei por mim mesma, fui influenciando meus colegas, falando "Eu tô pegando livros emprestado na biblioteca". A partir do momento que eu fui pedir pra ela, ela deixou emprestar, e aí todo mundo começou a emprestar livro. [...] Ai, eu não sei [por que ela abriu uma exceção para mim]. Acho que foi por causa do meu interesse e por causa da minha persistência... [risos] Eu irritava, eu batia na porta, corria atrás dela, perguntava "E aí, não vai abrir a biblioteca, não?". Aí, quando a biblioteca estava aberta, eu ficava escolhendo os livros, colocava na mesa e falava assim: "Eu quero levar esses livros", entendeu, e ela... Eu até falei com os professores: "Como é que pode uma escola não poder pegar livros emprestados?". Eu ficava revoltada por causa disso. [...] Eu pensava assim: "Se a gente paga imposto e a escola é pública, então, eu tenho direito de pelo menos pegar emprestado. Assim como eu ganho livros didáticos, é paradidático, se eu não me engano, livros normais, de estudo, se a gente tem o direito de receber esses, por que a gente não pode ler outros livros mais interessantes, entendeu?

A despeito da ressalva de 4 sujeitos quanto à insuficiência das práticas de leitura no Ensino Médio, depreendemos dos relatos que ocorreu na escola uma mediação bem-sucedida da literatura de modo geral e dos clássicos da literatura brasileira no caso de 3 dos 5 pesquisados - Beatriz, Malik e Taiko:

Beatriz: Eu tive uma professora que mesmo ela gostava muito de literatura e ela falava muito da literatura para nós. [...] Ela leu uns trechos de Dom Casmurro que eu achei interessante e que eu falei: "Eu tenho que ler esse livro!". 
Malik: No primeiro ano, tive uma professora de verdade. Só que dela eu não lembro o nome. Mas ela passou para a gente livros alternados e eu escolhi Memórias do Escrivão Isaías Caminha do Lima Barreto. Esse livro veio assim como um marco que me fez caminhar para o que eu sou hoje, eu devo um pouco ao gibi do Konan, mas foi o Memórias do Escrivão Isaías Caminha.

Taiko: No ano passado, teve a professora Sílvia, no Matias. Ela dava aula de Português também. A matéria que eu mais gosto é de Português. Então, ela fez seminário. Meu seminário foi do Dom Casmurro, Machado de Assis. Teve vários seminários, então, ela fazia assim a gente ler porque ler é bom. Ela mostrava que ler era bom, e ela explicava as fases literárias bem explicadinho, tinha autoavaliação. $\mathrm{O}$ modo como ela trabalhava com os alunos era bem eficiente. Não tinha gente que ficava com nota vermelha na aula, não. Apesar de ser exigente. Ela é super nervosa, ela gosta de tudo certinho. Então, isso daí facilitava as coisas pra mim, porque eu também gosto das coisas certas...

Álvares, que também fez muitas críticas ao papel que a escola deixou de exercer para sua formação como leitor, fez uma concessão à atuação de alguns professores de Língua Portuguesa, que lhe apresentaram elementos que potencializaram sua compreensão e seu prazer estético. A citação de elementos específicos como semântica, métrica ou a questão da gênese do gênero romance apontam para uma mediação da leitura mais qualificada do que aquela vivida pelos sujeitos do grupo A:

\begin{abstract}
Álvares: Eles [os professores] me ajudaram, eles cristalizaram minha... eu já fui alfabetizado para a escola, me ajudaram no sentido de que... a gramática... e... a semântica. A semântica, pelo significado das coisas, das palavras, tal. Então, eu comecei a ter um prazer estético - era interessante - de alguma palavra, quando você lê uma poesia do Vinicius, $O$ Soneto da Fidelidade, aí você entende porque ele escreve daquele jeito, a métrica e tal. Alguma coisa você tem que saber sobre isso, Camões, a métrica, Os Lusíadas, Cervantes, como começa um romance moderno, e a literatura no geral é interessante também.
\end{abstract}

Interessante ressaltar o caso de Zapata, que se recusava a fazer algumas leituras exigidas pela escola, em função da mediação pouco significativa da literatura brasileira, da concepção de leitura como mera tarefa escolar e do preconceito do próprio sujeito contra o romance, motivado pela mediação precária desse gênero na escola:

Zapata: Porque eu fiquei uma vez na chamada recuperação de literatura, porque eu não lia os livros. [...] "Se não ler esse livro, não vai passar. Tem que apresentar o seminário". [O livro era] Inocência, Visconde de Taunay. Ele tem outro nome além desse Visconde de Taunay. Foi um dos piores livros que eu já li. É lógico que vou ler esse livro de novo outras vezes, mas é uma perda de tempo porque eu poderia estar... não aprendi nada. Por outro lado, foi bom porque, em questão da estrutura mesmo, isso que eu acabei de falar do gênero narrativo. Só que foi ambíguo, né. Eu não gostei. Esse sim falava da Inocência que era moça e o cara veio, aí, ficou com ela e veio não sei quem que matou não sei quem, tipo $O$ tempo e o vento e tal, mas a diferença é isso, né. Você ainda consegue construir um monte de coisas. [...] Não lembro [em que ano eu estava]. Mas já era ensino médio, literatura de ensino médio. Aí tive que ler, apresentar o seminário e tal, foi tranqüilo, mas nem lembro do livro direito.

[...]

Romance não era nem questão de comprar, porque eu ia na biblioteca [pública]. É que a maioria eu não lia mesmo. Eu tinha também a ignorância de não saber, as pessoas falavam em romance que eu já falei. [...] É, [eu achava que era água com açúcar]. [...] Mas é essa visão que a gente aprende, como a gente aprende o que é romance. Chega numa criança e pergunta o que é romance? Novela, paixão, namorado. Eu falava: "Eu? Revolucionário, de esquerda, PSTU - nem existia PSTU naquela época... - vou ler romance? É brincadeira". Eu sempre fui, isso é bom em algumas coisas e ruim na maioria, sempre fui 
muito folgado nesse sentido. Falava que não ia fazer e não fazia mesmo. E, é lógico, que depois você tem que pagar por isso e eu não lia. Lia alguns só. Não li dos piores não, li Dom Casmurro, mas não lia. Li esse aí porque era obrigado.

Nos casos de 3 sujeitos - Beatriz, Malik e Zapata - saltou aos olhos a importância que a leitura de uma obra apenas ou a mediação relativamente curta de um professor assumiram para que se dispusessem a apreciar um determinado tipo de obra.

Na trajetória de Beatriz, por exemplo, a apresentação bem-sucedida dos clássicos da literatura, sua temática e linguagem parece ter se dado num período de apenas dois meses em que a professora efetiva foi substituída por outra professora, que, mais do que modelo de leitora, foi modelo de leitora dos referidos clássicos. As estratégias didáticas adotadas por tal professora substituta não tiveram nada de extraordinário. Consistiram da explicação de vocabulário, preenchimento de questionários e discussões de interpretação de texto, além de leitura de trechos de obras. Porém, a entrevistada foi seduzida pelo enorme entusiasmo com que tal professora/leitora falava das obras:

Beatriz: Eu tive uma professora que mesmo ela gostava muito de literatura e ela falava muito da literatura para nós. Ela não era bem uma professora... Era uma professora substituta. Ela ficou só um tempinho com a gente, porque tinha uma professora que ia fazer uma operação e ela ficou um tempinho com a gente e ela gostava de literatura e aí ela falava um pouco das literaturas para nós, lia os trechos de literatura. E foi assim que me interessei para ler o Dom Casmurro. Ela leu uns trechos de Dom Casmurro que eu achei interessante e que eu falei: "Eu tenho que ler esse livro". E eu procurei muito esse livro e eu não consegui ler esse livro, na escola de Poá. Eu não consegui ler esse livro de jeito nenhum, porque toda vez que eu ia na biblioteca tinha gente lendo ele.

[A professora substituiu] pouco tempo. Acho que assim uns dois meses ela ficou lá. [...] Ela passou um trechinho de Dom Casmurro, que eu me interessei. [...] Olha, eu gostava das duas [professoras]. A Gisele [professora efetiva] dava dicas de outros livros sem ser literatura. Ela falava de outros livros sem ser literatura. A Katia [professora substituta] gostava mesmo era de literatura. Toda aula dela tinha literatura brasileira. Ela falava bastante de literatura e sempre falava bastante de literatura e sempre passava trecho pra gente dos livros de literatura.

[Ela lia] em voz alta, trechos... Muitas vezes, ela passava um trecho por stencil e distribuía na sala. Ela passava questionário sobre aquele trecho mesmo da literatura e tinha que responder e discutir entre a sala. [Aí, eu comecei a me interessar mesmo por] literatura, eu comecei a gostar depois que essa professora foi passando os trechos das literaturas. Mas eu não gostava muito de literatura não, não me interessava, porque achava difícil para ler e eu não entendia. Eu não entendia a linguagem que eles usavam e eu achava muito difícil. E aí, depois que a professora começou a passar os trechos, aí sim, eu fui me interessando por literatura...

É [ela passava trechos das obras], falava das dificuldades, palavras que a gente não entendia.

$[\ldots]$

[Dom Casmurro eu] fui ler aqui. Eu consegui o com uma prima de lá de Poá, que mora lá, foi ela que me emprestou o livro Dom Casmurro. Tenho ele até hoje comigo, mas eu fui ler depois aqui, porque depois da mudança, eu não conseguia achar esse livro. Achei que eu tinha perdido. Eu tenho: Amar é um Verbo Intransitivo. Eu tenho esse livro aqui em casa. [...] É um pouco difícil, mas a gente leu com o dicionário e ia lendo ele.

Para Malik, teve grande importância o trabalho da professora de Língua Portuguesa durante o $1^{\circ}$. ano do Ensino Médio, que consistiu de oferecer opções de leitura de obras clássicas da literatura brasileira e promover debates entre grupos sobre seu conteúdo. A partir 
da atuação dessa professora e da leitura de uma única obra de Lima Barreto, parecem ter se aberto as portas para a leitura de literatura brasileira de modo geral:

\begin{abstract}
Malik: No primeiro ano, tive uma professora de verdade. Só que dela eu não lembro o nome. Mas ela passou para a gente livros alternados e eu escolhi Memórias do Escrivão Isaías Caminha do Lima Barreto. Esse livro veio assim como um marco que me fez caminhar para o que eu sou hoje eu devo um pouco ao gibi do Konan, mas foi o Memórias do Escrivão Isaías Caminha. Porque o Lima Barreto sempre ácido, né, com suas críticas à sociedade, a sociedade do século XIX, traz um menino que era preto vivenciando o racismo de várias formas, tentando trabalhar na redação do Jornal O Globo. E aí, aquelas histórias, eu me identifiquei com o personagem que era o Isaías e que ele gostava muito de ler e eu também gostava e eu me identifiquei com ele, e a questão das discriminações, que eu já sofria de montão e já identificava elas todo dia quase. Aí, teve um debate na sala de aula. A turma que era para ter feito comigo, o grupo, não leu, só eu li. Aí, eu fiquei sozinho no debate e a sala inteira. O debate quase me abateu porque ninguém concordava com o que o Lima Barreto estava dizendo.

$[\ldots]$

E aí, eu estava com o livro na mão e eu fui o único que leu. Nesse momento, eu gostei para caramba do Lima Barreto. [...] Eu quase saí de lá [do debate] sem vida. Porque o Lima Barreto questionava em vários momentos o racismo meio que escondido. [...] Mas o que esse livro do Lima Barreto contribuiu depois numa aula de literatura foi para dar um click assim: "Nossa, preciso ler mais sobre isso, meu Deus o que é isso?". No mesmo ano, eu li O Triste Fim de Policarpo Quaresma. E aí, eu consegui associar Lima Barreto a coisa boa. E aí, foi rolando.
\end{abstract}

Zapata, como dissemos antes, recusava-se a fazer as leituras propostas devido à concepção de leitura por obrigação ou como mera tarefa escolar e ao fato de acreditar que romances resumiam-se a narrativas "água com açúcar”. Também a partir da leitura de uma única obra, o sujeito reviu sua posição sobre a literatura em geral e o referido gênero em particular:

Zapata: Não [me lembro de nenhuma aula de literatura no ensino médio e de nenhum livro que me chamou a atenção], até porque a estratégia era didática e tal, mas o importante foi esse contato com o livro do Frei Beto, Alucinado Som de Tuba, o Júnior já deve ter lido. Ele conta a história de, não me recordo se é criança ou adolescente, que foi morar na rua... [Eu gostei tanto desse livro] porque nessa época eu já lia. Eu lia Marx, lia Harry Braverman, a Riqueza do Homem e eu já tinha a maior identificação com a luta de classes. E aí, ele veio como... eu não imaginava que a literatura e que um romance brasileiro discutia assim essas coisas. Fora a viagem, né. Eu gostei muito, tanto que é um livro que eu indico para todo mundo.

[...]

Acho que ele [O Alucinado Som de Tuba fez tanta diferença porque] me mostrou o que é literatura, que por mais... nessa época, é lógico que eu não tinha contato embora eu estava, acho que nem estava com o Sartre do William, que está comigo até hoje, mas não tinha contato com literatura, romance. Eu sabia o que era ler porque eu percebi que era um romance, inclusive depois teve aquele dia que a gente discutiu bastante que romance não é amor, que eu até aprendi na faculdade, né? Que Romance não é de amor. Romance para mim era de amor, como a maioria. Então, não tinha necessidade de ler livro de amor, né? Olha como eu era ignorante, mas era desconhecimento mesmo. Então, não lia, né, e aí, eu aprendi o que era, apesar que está mais para novela O Alucinado Som de Tuba, mas foi o escritor e foi um livro muito gostoso de ler. [...] Me marcou por isso, eu aprendi, eu conheci esse gênero na verdade que eu deveria ter aprendido no mínimo na quarta série. Tem que conhecer os gêneros literários, embora tive o contato lá na cartilha, mas se o próprio ensino não faz a relação, você não vai fazer. E eu gostei para caramba, tanto da questão ideológica, ele faz uma denúncia contra a sociedade brasileira, quanto a função dos sentidos. Porque eu gosto assim e acho que foi a partir daí que eu comecei a escrever rap. [E hoje] escrevo aí mais na parte do conto, escrevo conto. Não gosto, não é que não gosto, não tenho muita habilidade para poema, mas arrisco alguns também. 
No entanto, Zapata não credita à escola o fato de ter passado a ler também literatura:

Zapata: Agora, a escola... eu leria o que eu li até hoje sem escola mesmo, que uma hora eu ia encontrar com Alucinado Som de Tuba e a escola continua sendo o principal dificultor [sic], [para a formação do leitor], me parece, não sei.

Acredito que o fato de a leitura de um único livro ter tornado esses 3 sujeitos mais dispostos a ler outras obras clássicas da literatura esteja vinculado ao fato de eles já terem desenvolvido práticas de leitura de outros materiais anteriormente - revistas, literatura infanto-juvenil ou obras de Filosofia e Sociologia, conforme o caso - ao longo do $2^{\circ}$. segmento do Ensino Fundamental, seja na escola (no caso de Beatriz e Malik), seja no grupo de estilo ou militância (no caso de Zapata).

Resumiremos a seguir as concepções de leitura no $2^{\circ}$. segmento do Ensino Fundamental e no Ensino Médio que depreendemos dos relatos. Três sujeitos - Álvares, Taiko e Zapata - criticaram a concepção de leitura por obrigação e sua apresentação como mera tarefa escolar, sempre vinculada à obtenção de nota. Dois leitores - Álvares e Taiko disseram ter se ressentido da concepção de leitura como algo a sonegar aos alunos. Um sujeito - Álvares - referiu-se à visão da leitura como prática desagradável e difícil, e ao fato de os professores não verbalizarem sua crença na possibilidade de se aprender a ler textos e obras cada vez mais complexas. Apenas 2 leitores, Beatriz e Taiko, mencionaram uma visão positiva - a leitura como fonte de prazer - no âmbito da escola. Para Beatriz, essa concepção esteve presente da $5^{\mathrm{a}}$. série ao $2^{\circ}$. ano do Ensino Médio; já para Taiko, ela foi verbalizada apenas por 2 professores em 2 anos letivos diferentes.

A exemplo do que aconteceu no grupo A, também no grupo B, a responsabilidade pelo desenvolvimento de práticas de leitura incidiu preponderantemente sobre o professor de Língua Portuguesa. As práticas pedagógicas desse profissional, de modo geral, foram bastante tradicionais. Consistiram de aulas expositivas, solução de dúvidas dos alunos e demonstração de interesse por eles no caso de uma e também de seminários e auto-avaliação no de outra. É digno de nota que Taiko tenha avaliado como qualidades importantes das docentes o fato de prepararem aula e serem organizadas. É fácil compreender a valorização que Taiko deu a isso quando se sabe que a aluna ressentia-se de falta de professores efetivos. Até final de março de 2008, quando cursava o $3^{\circ}$. ano do Ensino Médio, Taiko havia conhecido apenas professores eventuais daquele ano letivo.

Para 2 dos 5 leitores do grupo B - Beatriz e Malik -, houve outras pessoas no âmbito da escola, para além dos professores de Língua Portuguesa, que exerceram mediação de 
leitura. Para ambos os sujeitos, os amigos leitores da mesma sala de aula tiveram grande importância. Houve, no caso de Beatriz, toda uma sociabilidade que girava em torno do livro:

\begin{abstract}
Beatriz: [À biblioteca, a gente] ia sempre na hora do nosso intervalo, porque no horário de aula a gente não podia ficar indo na biblioteca, mas no intervalo, juntava o nosso grupinho e já ia pra biblioteca pegar livro. [...] Era, na verdade, da minha sala, do nosso grupinho, porque tinha outros grupinhos também que gostavam de ler, mas não ficavam com a gente. Agora, do meu grupinho, da minha sala era eu, a Paula e um amigo nosso, o Danilo. E tinha das outras salas que já estavam mais adiantados que a gente. Tinha a Heloísa, a Carla que eram amigas lá de Poá mesmo, e o Danilo, eu conheci mesmo estudando lá na escola. Ele sempre gostou de ler. Assim, juntava todo mundo e ia pegar livro na biblioteca. [A Heloísa e a Carla eram do] mesmo bairro que a gente, já que o bairro lá era pequeninho e a gente vivia uma na casa da outra. [A gente trocava livros e figurinhas com elas] com certeza. A Heloísa e a Carla era um ano na frente que eu, minha irmã e o Danilo. Eu acho que uma incentivou a outra [a ler].

$[\ldots]$

Eu ganhei [o livro que estou lendo] das minhas amigas lá de Poá. Elas [as minhas amigas] tinham ele e aí elas me deram. Elas disseram: "Pode ficar para você". E aí eu peguei, li e gostei demais.
\end{abstract}

Malik, por sua vez, teve um amigo na $4^{\mathrm{a}}$. e $5^{\mathrm{a}}$. séries, que lhe franqueou acesso a gibis, com o qual ele manteve interlocução a respeito desse material de leitura e sua linguagem. Na época, a curiosidade do sujeito foi intensamente instigada pelo vocabulário complexo dos gibis do personagem Konan e pelas referências a lugares distantes, com apresentação inclusive de mapas. O sujeito acredita que a leitura de tais gibis tenha sido um dos fatores que o levaram a optar futuramente pela graduação em Geografia. Durante todo o Ensino Médio, Malik teve outro colega, onze anos mais velho, que se tornou seu melhor amigo. Essa pessoa, foi um modelo de leitor mais experiente e crítico, de apreciador de vários gêneros musicais e de dono de biblioteca pessoal. Constituiu-se um representante da cultura tipicamente letrada, disseminando seus conhecimentos e incitando o sujeito à reflexão e à análise literária, via letras de música. Introduziu-o também ao grupo de estilo rap:

Malik: Konan era só na quarta série. E o Konan eu lia emprestado. Tinha um menino que o pai dele era dono de uma banca de jornal e ele era da minha sala. Esse menino estudava junto comigo e o pai dele era dono de uma banca de jornal. [...] Quando eu morava lá, era outra parte da zona leste. Ele era dono de banca de jornal, de locadora. Era uma realidade engraçada daquela escola. Era uma escola de ensino forte, de regras fortes e tinha estudante de classe média porque, para você ter, na década de noventa, uma banca de jornal, uma vídeo-locadora no período dos planos econômicos mirabolantes do Collor, era um cara de poder aquisitivo razoável. Tinha gente que morava na favela, que era meu caso, e tinha gente que era dono de comércio e tal. A gente falava sobre o Konan, a gente acha que o Konan era trash. [A gente falava] palavras complicadas e eu achava isso da hora e isso me aproximou muito dele. [...] Eu lembro do nome e sobrenome dele, era Clayton Bossi Pimenta. Era descendente de italianos. Foram dois anos [de convivência], da quarta à quinta série. E, quando fui ver, eu já gostava de ler já. $[\ldots]$

Tinha uma peculiaridade nessa escola [no ensino médio, no Tatuapé]: tinha muitos adultos, pessoas muito mais velhas. Talvez pelo curso de contabilidade, na minha sala, eu era um dos mais novos ou o mais novo, provavelmente mais novo, tinha muito adulto ali. Meu melhor amigo tinha vinte e cinco anos. E eu tinha catorze quando conheci ele. [Ele] lia, nossa, ele era... [Ele me influenciou para ler] bastante. Ele era um roqueiro, gostava de rap. Ele era um roqueiro da antiga, mas roqueiro de verdade. Gostava de rap, gostava muito de MPB, gostava muito de MPB, ele era um cara eclético pra caramba. Até hoje eu tenho amizade com ele. E a gente debatia muito. E eu gostava de pagode, olha que lixo. Eu 
gostava de pagode e um dia eu pedi: “Ô João, grava uma fita lá pra mim”. Que não tinha CD, né. Então, eu falei: "Grava uma fita lá pra mim, grava o som do Katingulê de um lado e da Legião Urbana de outro". Aí ele falou: "Não, mano eu não vou gravar para você não. Eu gravo Legião Urbana". E eu: "Não, samba é música popular". E ele falou: "Isso não é música popular, isso é uma forma massificada de dominação". E eu: "Mano, de onde você está tirando isso? Você está ficando louco". Isso foi no primeiro ano, eu com catorze anos. E ele: "Não, vamos pensar direito". Aí, ele me levou na casa dele, me apresentou algumas coisas de música. Aí, ele me mostrou a biblioteca dele. Olha só, falando de prática de leitura, e meus amigos é que me iniciaram. E aí, eu me lembro, foi a primeira vez que vi um livro do Eduardo Galeano, Veias Abertas da América Latina, mas eu não peguei para ler. Eu não peguei para ler, mas ele me mostrou o livro, mas eu lembro que o que peguei com ele mesmo para ler foi a biografia do Bob Marley. Olha só, estou lembrando as coisas: ele me mostrou um som que era um rock progressivo que chamava Casa das Máquinas e aí, eu pirei, naquele som, e aí, que eu fui entender porque ele falava que o som do Katinguelê era música alienada. Aí, foi a provocação. Foi uma provocação boa. [...] Tinha uns livros lá e o que eu lembro bastante é do Veias Abertas da América Latina, capa branca, vermelha, preta, vermelha e aquilo chamava a atenção e, como eu conversava muito com ele, porque ele era diferente da maioria da turma, e como ele era mais velho e tinha muitas experiências, ele me mostrava outras coisas. Ele gostava muito de repente, dos repentistas. Ele gostava muito e até me ensinava umas rimas, assim. E ele me ajudou, e é um cara branco, me ajudou a entender o rap. Eu gostava de rap, mas... E ele me falou: "O rap tem uma letra que você tem que prestar mais atenção". Eu disse: "Ah, eu conheço Racionais". Então, ele disse: "Vamos ouvir melhor". Daí, eu fui começar a ver outras coisas, mas, como ele era um cara muito crítico, essa criticidade dele me contaminou, porque eu já tinha meu arremedo de crítica do Lima Barreto e minha experiência de vida lá, nossa... [Ele me] deu [uma outra visão]. Porque eu estava indo naquela pegada típica de um jovem meio cabeção. Eu freqüentei o shopping durante os catorze até os quinze anos. Saía do trabalho, pessoal ia para o shopping, se não fosse para a escola, eu ia para o shopping também, que ridículo. Para o Shopping Aricanduva. E com ele eu comecei a ver outras coisas e, a partir daí, é a partir disso: Lima Barreto, a influência do João, os livros de José William Vicentini. E aí, foi embora... [Fazer análises das letras de raps, conforme o João me incentivou] ajudou bastante [nas análises de poesia, romances, contos]. Fazer umas análises dessa, com certeza, me facilitaram em outras análises, com certeza. Ajuda bastante porque, se você pega essa parte que esse menino se confundiu quando o Consciência Humana fala "A polícia não tem nível de faculdade" e ele entende universidade, e eu estava até interpretando que o grupo queria mesmo dizer que os policiais não precisavam de universidade para ser policiais, mas não era isso, não, o que essa música está pontuando é que eles não têm escolha a não ser a repressão. Fazer umas análises dessa, com certeza, me facilitaram em outras análises, com certeza. Várias outras letras de rap são complicadas até para as pessoas entenderem.

Se, por um lado, Beatriz e Malik tiveram amigos leitores, não deixa de ser interessante citar, por outro, os casos de 2 sujeitos - Álvares e novamente Malik - que foram hostilizados por colegas por seus hábitos de leitura, seu desempenho escolar, sua condição socioeconômica e sua aparência física, num processo que se chamaria contemporaneamente de bullying. Para ambos os alunos, a hostilidade foi motivo de sofrimento. Mas, para Malik, ela parece ter sido também um fator de motivação para estudar e ler ainda mais. O sujeito criou secretamente muitas histórias em quadrinhos sobre as quais nunca havia contado a ninguém até o dia da entrevista. Não por acaso, o protagonista das narrativas que o sujeito imaginava era um leitor e o antagonista, um menino de outra classe social. Vejamos o que ambos relatam:

\footnotetext{
Álvares: Não [eu não gozava de prestígio com meus colegas de classe por ser leitor], eu era excluído, eu apanhava quase todo dia, porque eu tinha a melhor nota, não passava cola pra ninguém, eu era muito sério, introspectivo. Então, todo mundo me batia todos os dias, que eu era excluído. Até o meu nome ser Álvares também, já era um pretexto, qualquer coisa era motivo para o ser humano... ele está menos socializado quando ele é mais novo, ele está menos socializado, ele é mais cruel, ele demonstra todo um
} 
machismo, tudo que tem de mal na sociedade e que ele pode fazer ele reproduz. Então: "Oh, seu macaco, seu preto, seu Tonho da lata, seu não sei o quê...”. Então, quer dizer que você é diferente e acaba você sendo excluído. Eu me sentia muito excluído, eu me sentia muito sozinho. Muitas épocas da minha vida eu me senti sozinho.

Malik: Eu queria dar uma resposta. Eu não sabia o que era o sistema. Isso já na quinta série. E eu não sabia o que era o sistema, mas eu queria mostrar que eu podia ler, que eu podia ir além, que eu podia ser mais do que estava colocado para mim. Aquele choque que tinha nisso: foda-se a exceção, né. O fato de misturar na mesma turma assim um boyzinho que estudava naquela escola com uma galera da favela, e eu era um da favela no meio, sai da turma $\mathrm{D}$ e vai para a turma $\mathrm{A}$, no ano seguinte. Eu entro no primeiro $\mathrm{D}$ e vou para o segundo A, isso foi um choque para... ele chamava Wellington. [Ele] era boyzinho e depois ele pegou uma carta de amor que eu escrevi para uma menina que eu era apaixonado e ele leu. E a carta era da hora, era bonita. Aí, ele leu em voz alta. Eu queria mostrar que eu era melhor do que ele, que eu era o melhor aluno e eu acreditava nisso. [...] Era o campo que eu tinha para bater nele, porque fisicamente e economicamente ele batia em mim. [risos] Eu fiz isso muitas vezes mesmo nos meus personagens fictícios: ele era o meu inimigo. E um dos meus heróis, ele era o leitor. E ele era um estudante, e andava de skate, essas coisas assim e criei um herói que era estudante. Eu criei, ele [o boyzinho, o Wellington] era o vilão dessa história. Muito provavelmente o heroizinho era eu, né. Eu não tinha pensado nisso, mas muito provavelmente esse herói que eu criei, que nas horas vagas ele estudava, era eu. [...] Eu tinha que dar uma prova para aquele pessoal. Na quinta série, aconteceu uma coisa: uma vez, a gente entrou na escola e a escola estava em reforma e aí tinha um vaso sanitário no meio do pátio e o filho da puta do Renato, eu falei: "Ih,olha lá Renato, a sua privada lá". Falei zoando, brincadeira de moleque. Aí ele falou: "Não, é sua, porque você é favelado". Filho da puta, mas você engole seco. E ele sempre vinha pedir para mim, para eu fazer os trabalhos para ele e eu não fazia nunca. Então, acho que ele pensou: "Agora você vai ter que engolir isso, mano". Essas coisas, esse conflito que tinha entre meios, nós éramos pobres demais. Ele tinha que me aplaudir com freqüência e eu usava isso para ganhar.

Ao contrário do que aconteceu no grupo A, o livro didático de Língua Portuguesa aparentemente exerceu uma mediação positiva da leitura para 4 dos 5 leitores do grupo B Álvares, Malik, Taiko e Zapata - em alguns momentos de seu percurso escolar.

No Ensino Fundamental, 3 sujeitos - Álvares, Malik e Zapata - leram antecipadamente os textos de literatura do livro didático. No caso de Malik e Zapata, as cartilhas foram fonte importante de material de leitura. É muito significativo que, passados cerca de 20 anos, Malik e Zapata ainda se lembrem do conteúdo de algumas narrativas da cartilha. Vejamos o que os 3 sujeitos relataram:

Álvares: Aí, eu pegava os livros da escola: na... Eu estava na terceira série, eu pegava livros da quinta, sexta, sétima série para eu ver o que ia ter depois. Eu sempre pegava livros assim, estava na quarta, pegava da quinta, assim... [Eu pegava os livros] na biblioteca da escola os livros paradidáticos. Eu tinha acesso a livros paradidáticos, mais paradidáticos.

Malik: Na segunda série, eu fiz isso e na terceira também, com o livro Caminhando, olha só. Se eu falar que eu lembro da história, você não acredita. Uma história que era o bicho ia levar presépio para Jesus, para o nascimento de Jesus. Era uma história que era um pouco maior porque era no fim do livro, na segunda série e eu já lia inteirinho, já. E lia os textos [dos livros didáticos] no fundamental, quando eu estudava lá no Jardim Maria Fernanda, aqui já nem tinha mais.

Zapata: Mesmo meus irmãos, o Edney e o William, ficava naquela cartilha lá discutindo os textos, lendo. Não discutindo como hoje, pedindo para eu escrever, mas a gente gostava muito da cartilha, lá que eu tenho que ler porque eu tenho quase certeza que eu não daria para o meu aluno, nem ferrando, mas a gente gostava muito, Caminho Suave. Tinha uns textos muito bacanas. Eu lembro que o que a gente ficou mais assim foi $O$ Quintal da Bicharada. Tinha o um e o dois e tinha quintal, tinha vários 
bichos e sempre aquela imitação da fábula, do lobo que ia pegar os bichos, não sei o quê. Discutia assim esses textos, as narrativas curtas. Eu acho que é importante para a formação do leitor, o problema é como a escola faz. Para que tem esses textos na cartilha, que hoje não existe mais, que hoje é o livro didático mesmo. Não era livro didático nessa época, era cartilha. Na cartilha, tinha os conteúdos, Português e Matemática e os outros. Depois esses textos é para que, era para incentivar a formação de leitores. E, por exemplo, no nosso caso, foi importante porque a gente já tinha alguma coisa aguçada para isso porque a forma que é trabalhada a ler, fazer interpretação de texto, responder as perguntas e traz, isso não forma leitor. Por isso que eu falo que é a estratégia de leitura que vai depender da formação do professor.

Pesquisadora: Você acha que esses textos incentivavam vocês que já tinham essa coisa aguçada porque tinham essa prática de leitura dento de casa?

Zapata: E eu ainda estou falando de coisa de nove, dez anos. A gente lia, brincava. Discutia assim, né. [...] A gente ficava lendo e conversando sobre o texto, lia bastante, era isso, né.

No $2^{\circ}$. segmento do Ensino Fundamental, Malik e Zapata não utilizaram livros didáticos de Língua Portuguesa. Para Beatriz, o livro didático não parece ter sido muito significativo. Já Álvares fez dele mais uma opção de material de leitura e continuou a ler antecipadamente textos das séries que cursaria depois.

No Ensino Médio, a mediação do livro didático pareceu pouco significativa. Apenas Taiko acredita que o referido livro a incentivou a ler porque, ao mostrar trechos de uma determinada obra, despertou curiosidade sobre o restante dela:

Taiko: [O livro didático de Língua Portuguesa] incentiva bastante [a ler], porque se tem um trecho de um livro, aí, você fica curiosa para saber o resto da história, ou se é um trecho que foi pego pela metade do livro, você quer saber o começo, entendeu? É muito bom isso que eles estão fazendo agora, com os livros, colocando trechinhos, os livros recomendados pelos editores, muito bom.

Aqui talvez caiba uma discussão sobre o papel do livro didático para populações com restrição de acesso a material impresso. Embora se critique o caráter fragmentário da apresentação que ele faz da literatura e o fato de não inserir o aluno na ordem dos livros, nos casos de Taiko e de Malik, e, em menor grau, de Álvares, o livro didático funcionou como fonte importante de textos para leitura e de textos de literatura. No caso de Taiko, teve o papel de despertar o interesse para a leitura do restante do livro. Assim, nas condições nas quais se encontravam os sujeitos da presente pesquisa, haver livros didáticos foi (ou teria sido) mais positivo do que não haver.

Para 3 pesquisados do grupo B - Malik, Taiko e Zapata -, cursos que se seguem ao encerramento do Ensino Médio tiveram ou vêm tendo grande importância para sua constituição como sujeitos que incluem literatura brasileira no rol de suas leituras. No caso de Malik, os cursos pré-vestibulares que fez até conseguir ingressar na universidade pública favoreceram o acesso a material impresso, o desenvolvimento de mais leituras mediadas por professores bastante comprometidos e a leitura de literatura brasileira, com vistas ao vestibular. Foi nessa época que Malik descobriu que uma obra clássica de Machado de Assis, 
ao contrário do que se dizia, era de compreensão muito fácil - ao menos para o sujeito - e, além de tudo, fonte de prazer:

Malik: Mas aí já tinha a possibilidade de vestibular e aí no ano de 2002 eu já tinha comprado alguns livros. Eu li dois livros [da literatura obrigatória para o vestibular], de verdade, que eu comprei. Li Macunaíma e Memórias Póstumas de Brás Cubas [e depois] foi A Hora da Estrela, da Clarice Lispector, foi que eu fui a pé até a Biblioteca de Guaianases. [...] Memórias Póstumas de Brás Cubas me marcou porque todo mundo falava que era difícil e eu achei "mó" fácil. "Eu não sei se eu sou um autor defunto ou um defunto autor". Eu disse: "Ah, ele está trabalhando nessa parte um monte de coisa. Gramaticalmente, o que era um substantivo numa hora vira adjetivo na outra. Não sei [por que o pessoal acha tão difícil]. Sei lá [porque todos acham tão difícil e eu achei fácil]... Não sei [porque todos acham tão sem graça e eu não achei]. Uma outra incógnita. Aquela viagem que ele faz pelos séculos, eu achei "da hora" aquilo.

No caso de Zapata, algo inusitado aconteceu: o sujeito, que sempre tivera apreciado Filosofia e História, optou pela graduação em Letras em nome do bem da BCST, decisão que detalharemos quando falarmos no grupo de pares. É bem verdade que Zapata já tinha desenvolvido muitas leituras de vários gêneros, em especial de Ciências Sociais, mas a leitura e apreciação de obras clássicas da literatura foi favorecida na universidade. Nesse sentido, é possível dizer que houve uma espécie de adiamento da mediação qualificada desse tipo de obra para o Ensino Superior:

\begin{abstract}
Zapata: [Fazer Letras na PUC não contribuiu para meu] gosto [por ler] não, porque eu acho que a leitura é uma ação como comer, não é uma questão de gosto. Leitura faz parte da sua necessidade. Ela [a graduação em Letras] ajudou muito no entendimento das coisas, conhecer a estrutura da língua, as variações, a Lingüística. Na questão da literatura brasileira, a estrutura, análise de texto ajudou muito. E também que inegavelmente você tem que ler muito mais... Eu gosto [de literatura brasileira]. Só que vou ler pessoas que eu nunca leria se eu não fosse ser professor, como Rui Barbosa, Machado de Assis; eu já li Dom Casmurro e Memórias Póstumas de Brás Cubas, mas tem que ler de novo e mais umas cinquienta vezes. E, nessa organização [da leitura] que estou fazendo, tem gente que passaria batido. Eu leria mesmo, brasileiro que seria o Lima Barreto, toda a obra. Gostei do Guimarães Rosa pela linguagem, uma linguagem... Ele é o rei do neologismo e os livros dele têm toda uma linguagem coloquial. Gostei muito. E o [contato com o] Guimarães Rosa foi pela faculdade.Tinha uma disciplina que deram Grande Sertão Veredas que aí eu li e gostei. E eu até continuaria lendo porque tem um pouco do professor, porque o professor de literatura, lá tem vários, mas esse Erson é um professor muito bom. E eu me identifico pelo jeito dele e ele é marxista também. E, então, a gente acaba se influenciando. E aí acaba se apegando. E os textos são fundamentais. Agora, se você me perguntar do grau de dificuldade dos textos da faculdade, são muito difíceis, eu acho... [Quando eu comecei a ler literatura na faculdade, eu] não [achei difícil]. Foi legal, gostoso. Eu acho muito, embora não é gosto, a literatura mexe com o seu cérebro.

[Antes,] eu não lia [literatura brasileira] porque é uma literatura burguesa. Mas eu aprendi, quando li Lima Barreto, que para mim estava no mesmo balaio. E aí, quando eu tive contato através de um trabalho de uma professora que era da UNICSUL, hoje ela é de onde era o grupo de estudo ali da UNG, quando eu tive contato com Lima Barreto por causa dessa tese dela, que eu fui questionar e ela falou: "Não. Lima Barreto, quem levou foi Antonio Cândido, Astrogildo, não sei quem". Aí, eu fui ler e eu já tinha indicação do [meu irmão] de ler o Policarpo Quaresma, que eu nunca li. Fui lendo e acabei lendo os principais e pretendo ler toda a obra.
\end{abstract}

No caso de Taiko, que ainda cursava o $3^{\circ}$. ano do Ensino Médio quando o depoimento foi coletado, os cursos e palestras promovidos pela EDUCAFRO vêm lhe indicando leituras 
de literatura a fazer e os procedimentos a seguir para a futura inserção no Ensino Superior público, informações essas que a pesquisada acredita lhe serem sonegadas pela escola.

Em síntese, os sujeitos do grupo B desenvolveram mais práticas de leitura no âmbito da escola do que os pesquisados do grupo A. E, embora a atuação da escola quanto à mediação da leitura e dos conhecimentos mereça as muitas críticas que lhes foram feitas pelos sujeitos, temos duas impressões: a) a escola por eles freqüientada foi um pouco menos ruim que aquela a que tiveram acesso os sujeitos do grupo $\mathrm{A}$; b) eles conseguiram ter um desempenho e uma relação com o saber mais positiva desde os primeiríssimos anos da escolarização, seja porque capitalizaram os conhecimentos que a própria família mediou (como foi o caso de Álvares, Beatriz, Taiko e Zapata), seja porque foram objeto de elogios por professores e de práticas docentes mais comprometidas e desafiadoras (como aconteceu com Malik e Zapata). Assim como acontecera com o grupo A, nas escolas dos sujeitos do grupo $\mathrm{B}$, a responsabilidade pela formação leitora incidiu majoritariamente sobre o professor de Língua Portuguesa. Porém, ao contrário do que aconteceu com o primeiro grupo, no grupo $\mathrm{B}$, a mediação do livro didático foi positiva para a maioria dos sujeitos. Um último aspecto que emergiu dos depoimentos, em face da precariedade da mediação de leitura pela escola básica, foi a relevância dos cursos feitos depois do encerramento do Ensino Médio, em especial, os pré-vestibulares comunitários e a graduação, em Letras para um terceiro.

\subsubsection{A mediação de leitura na escola: comparando os grupos A e B}

Para ambos os grupos de leitores a escola foi, sem sombra de dúvida, terrivelmente omissa quanto a seu papel de formação de leitores. De modo geral, ou não se fomentava práticas de leitura nesse ambiente ou a apresentação que se fazia delas era pouco atraente ou bastante negativa, quase sempre contaminada por concepções de leitura por obrigação ou como tarefa escolar desagradável e difícil. Além disso, esse espaço não favoreceu o acesso a material impresso (a não ser talvez por um ou outro colega) e, em muitos casos, nem mesmo ao livro didático. Os sujeitos parecem ter se constituído leitores (e não sido formados) graças à mediação de leitura que se deu em âmbitos diversos para além da escola - em especial, em outras modalidades de escolarização (OME), na família e nos grupos de pares ${ }^{91}$.

\footnotetext{
91 No grupo B de leitores, a família parece ter sido o âmbito que mais favoreceu o desenvolvimento de práticas de leitura em 4 sujeitos - Álvares, Beatriz, Taiko e Zapata. No caso deste último pesquisado, teve grande importância o grupo de pares, particularmente, os colegas da militância, conforme veremos quando me dedicar à análise desse âmbito. Apenas no caso de Malik, a escola teve um papel mais decisivo para sua constituição. E, na escola, foi essencial, para ele o contato com um mediador muito mais experiente.
} 
Embora, de modo geral, a omissão da escola tenha sido estarrecedora para a maioria dos sujeitos durante a maior parte do tempo, parecem ter existido algumas diferenças sutis entre os grupos A e B na sua trajetória escolar, as quais tentei explicitar anteriormente.

Comparando-se os 2 grupos, percebemos que os sujeitos do grupo B parecem ter desenvolvido práticas de leitura durante mais tempo do que os sujeitos do grupo A. Em primeiro lugar, no grupo A, 7 dos 8 sujeitos aparentemente começaram a ler com certa autonomia (e não apenas para atender a eventuais demandas escolares) mais tarde: AK47, aos 16 anos; André, no segundo segmento do Ensino Fundamental; Dandara, apenas depois de adulta; Frida e Laís, ao ingressar na BCST; Maria, por volta de 15 anos; e Marley, durante a adolescência. Para 6 desses sujeitos, a mediação de leitura que se daria posteriormente no espaço da BCST é que seria decisiva para que se tornassem leitores. Já 4 sujeitos do grupo B - Álvares, Beatriz, Malik e Taiko - parecem ter desenvolvido práticas de leitura mais autonomamente desde a infância.

No grupo A de leitores, a ausência de um trabalho de desenvolvimento de práticas de leitura foi mais longa, conforme se percebe na tabela abaixo. A inexistência de práticas de leitura ou sua interrupção no $2^{\circ}$. segmento do Fundamental podem ter contribuído para a mediação muito mal-sucedida da literatura brasileira no Ensino Médio, mesmo se eventualmente a apresentação nesse nível pelo professor tivesse sido bem feita. 


\section{Grupo A (leitores)}

\begin{tabular}{|c|c|c|c|c|c|c|c|c|c|c|c|}
\hline & \multicolumn{4}{|c|}{$\begin{array}{c}1^{o} \text {. segmento do Ensino } \\
\text { Fundamental }\end{array}$} & \multicolumn{4}{|c|}{$\begin{array}{c}2^{o} . \text { segmento do Ensino } \\
\text { Fundamental }\end{array}$} & \multicolumn{3}{|c|}{ Ensino Médio } \\
\hline & $1^{\mathrm{a}}$. & $2^{\mathrm{a}}$ & $3^{a}$ & $4^{a}$ & $5^{\mathrm{a}}$ & $6^{\mathrm{a}}$ & $7^{\mathrm{a}}$ & $8^{a}$ & $1^{\circ}$. & $2^{\circ}$ & $3^{\circ}$. \\
\hline AK47 & $\varnothing$ & $\varnothing$ & $\varnothing$ & $\varnothing$ & $\varnothing$ & $\varnothing$ & $\varnothing$ & $\varnothing$ & $\varnothing$ & $\varnothing$ & $\varnothing$ \\
\hline André & $\varnothing$ & $\varnothing$ & $\varnothing$ & $\varnothing$ & $\mathrm{L}$ & $\mathrm{L}$ & $\mathrm{L}$ & $\mathrm{L}$ & $\mathrm{P}$ & $\mathrm{P}$ & $\mathrm{P}$ \\
\hline Dandara & $\varnothing$ & $\varnothing$ & $\varnothing$ & $\varnothing$ & $\varnothing$ & $\varnothing$ & $\varnothing$ & $\varnothing$ & $\varnothing$ & $\varnothing$ & $\varnothing$ \\
\hline Frida & $\mathrm{L}$ & $\mathrm{L}$ & $\varnothing$ & $\varnothing$ & $\varnothing$ & $\varnothing$ & $\varnothing$ & $\varnothing$ & $\mathrm{P}$ & $\mathrm{P}$ & $\mathrm{P}$ \\
\hline Laís & $\varnothing$ & $\mathrm{L}$ & $\mathrm{L}$ & $\mathrm{L}$ & $\varnothing$ & $\varnothing$ & $\varnothing$ & $\varnothing$ & $\varnothing$ & $\varnothing$ & $\varnothing$ \\
\hline Maria & $\varnothing$ & $\varnothing$ & $\varnothing$ & $\varnothing$ & $\varnothing$ & $\varnothing$ & $\varnothing$ & $\varnothing$ & $\mathrm{L}$ & $\mathrm{L}$ & $\mathrm{L}$ \\
\hline Marley & $\mathrm{L}$ & $\mathrm{L}$ & $\varnothing$ & $\varnothing$ & $\varnothing$ & $\varnothing$ & $\varnothing$ & $\varnothing$ & $\varnothing$ & $\varnothing$ & $\varnothing$ \\
\hline Paula & $\varnothing$ & $\varnothing$ & $\varnothing$ & $\varnothing$ & $\mathrm{L}$ & $\mathrm{L}$ & $\mathrm{L}$ & $\mathrm{L}$ & $\mathrm{P}$ & $\mathrm{P}$ & $\mathrm{NC}$ \\
\hline
\end{tabular}

\section{Grupo B (leitores de literatura)}

\begin{tabular}{|c|c|c|c|c|c|c|c|c|c|c|c|}
\hline & \multicolumn{4}{|c|}{$\begin{array}{c}1^{o} \text {. segmento do Ensino } \\
\text { Fundamental }\end{array}$} & \multicolumn{4}{|c|}{$\begin{array}{c}2^{\circ} . \text { segmento do Ensino } \\
\text { Fundamental }\end{array}$} & \multicolumn{3}{|c|}{ Ensino Médio } \\
\hline & $1^{\mathrm{a}}$. & $2^{\mathrm{a}}$ & $3^{\mathrm{a}}$ & $4^{\mathrm{a}}$. & $5^{\mathrm{a}}$ & $6^{\mathrm{a}}$ & $7^{\mathrm{a}}$ & $8^{\mathrm{a}}$ & $1^{\circ}$. & $2^{\circ}$. & $3^{\circ}$ \\
\hline Álvares & $\mathrm{L}$ & $\mathrm{L}$ & $\mathrm{L}$ & $\mathrm{L}$ & $\mathrm{L}$ & $\mathrm{L}$ & L & L & $\mathrm{L}$ & $\mathrm{L}$ & $\mathrm{L}$ \\
\hline Beatriz & $\varnothing$ & $\varnothing$ & $\varnothing$ & $\varnothing$ & $\mathrm{L}$ & $\mathrm{L}$ & $\mathrm{L}$ & $\mathrm{L}$ & $\mathrm{L}$ & $\mathrm{L}$ & $\mathrm{NC}$ \\
\hline Malik & $\mathrm{L}$ & $\mathrm{L}$ & $\mathrm{L}$ & $\mathrm{L}$ & $\mathrm{L}$ & $\mathrm{L}$ & $\mathrm{L}$ & $\mathrm{L}$ & $\mathrm{L}$ & $\mathrm{L}$ & $\mathrm{L}$ \\
\hline Taiko & $\mathrm{L}$ & $\mathrm{L}$ & $\mathrm{L}$ & $\mathrm{L}$ & $\mathrm{L}$ & $\mathrm{L}$ & $\mathrm{L}$ & L & $\mathrm{L}$ & $\mathrm{L}$ & $\mathrm{NC}$ \\
\hline Zapata & $\mathrm{L}$ & $\varnothing$ & $\varnothing$ & $\varnothing$ & $\mathrm{P}$ & $\mathrm{P}$ & $\mathrm{P}$ & $\mathrm{P}$ & $\mathrm{P}$ & $\mathrm{L}$ & $\mathrm{P}$ \\
\hline
\end{tabular}

$\underline{\text { Legenda }}$

Sujeito declarou ter desenvolvido práticas de leitura no âmbito da escola ${ }^{92}: \mathrm{L}$

Sujeito declarou que leituras foram propostas, mas ele não as fez: $\mathrm{P}$

Sujeito declarou não ter havido ou não se recordar de propostas de leitura na escola: $\varnothing$

Sujeito ainda não cursou essa série da escola: NC

Nesse contexto de muita omissão ou de mediação muito negativa da leitura pela escola, houve períodos raros em que um trabalho menos ruim ou até positivo parece ter sido realizado. À exceção talvez de Zapata, para os 4 sujeitos do grupo B, esses períodos parecem ter sido mais longos do que o foram para todos os sujeitos do grupo A (à exceção de Paula).

Depreendemos dos relatos que os períodos em que a escola favoreceu alguma prática de leitura coincidiram com aqueles em que os sujeitos não estudaram em Cidade Tiradentes. Em bairros mais centrais, pode ter havido não apenas uma maior mescla de classes sociais, o que favoreceu o acesso a material impresso e o contato com algum colega leitor, mas também práticas pedagógicas de melhor qualidade.

\footnotetext{
${ }^{92}$ A partir da $3^{\text {a }}$. série, utilizei como critério o fato de o sujeito declarar ter lido algum livro ou não naquela série.
} 
De qualquer modo, conforme vimos antes, sujeitos como Álvares, Beatriz, Taiko e Zapata talvez tivessem se tornado leitores independentemente da atuação da escola. Esse, no entanto, não parece ser o caso de Malik, cuja família detinha muito pouco capital escolar e econômico para aquisição de material impresso. Esse sujeito teve sua constituição como leitor muito favorecida no âmbito da escola, não apenas por conta de ter estudado em Cidade Tiradentes por apenas 3 anos, mas também por ter tido professores que o incentivaram e um melhor amigo que foi um mediador de leitura muito mais experiente. Mesmo no período em que estudou em Cidade Tiradentes, que ele classificou como sendo de "ostracismo da leitura" - da $6^{\mathrm{a}}$. à $8^{\mathrm{a}}$. Série -, Malik leu três livros, o que foi uma média muito superior ao número de livros lidos por 6 sujeitos do grupo A - AK47, Dandara, Frida, Laís, Maria e Marley - nas mesmas séries.

Uma outra característica importante que diferencia os sujeitos dos grupos A e B de leitura é como eles se descreveram como alunos. A despeito das barreiras à escolarização e à formação leitora que a própria escola impôs aos sujeitos, aparentemente, os leitores do grupo B tiveram, desde o início do Ensino Fundamental, uma relação melhor com o saber e se perceberam desde cedo como "alunos excelentes". Já os alunos do grupo A, à exceção de Frida, relataram ter tido seu aproveitamento comprometido em algum momento de seu percurso escolar. A tabela abaixo tenta evidenciar as diferenças entre os dois grupos.

\section{GRUPO A (leitores)}

\begin{tabular}{|c|c|c|}
\hline & Reprovações & Como o sujeito se descreveu como aluno \\
\hline AK47 & $6^{a}$. série & $\begin{array}{l}\text { Mau desempenho até a } 6^{\mathrm{a}} \text {. série. } \\
\text { Bom aluno a partir de então. }\end{array}$ \\
\hline André & & $\begin{array}{l}\text { Dificuldades no EF I. } \\
\text { Bom aluno em Humanas no EF II e EM. }\end{array}$ \\
\hline Dandara & $1^{\mathrm{a}}$. série & Muito ruim em Português. \\
\hline Frida & & Boa aluna. \\
\hline Laís & & Aluna com mais dificuldades que os irmãos. \\
\hline Maria & & Boa aluna, porém invisível. \\
\hline Marley & $4^{\mathrm{a}}$. série do EF, $3^{\circ}$. ano do EM & Aluno indisciplinado. \\
\hline Paula & $2^{\mathrm{a}}$. série do EF & Boa aluna depois da reprovação. \\
\hline
\end{tabular}




\section{GRUPO B (leitores de literatura)}

\begin{tabular}{|c|c|c|}
\hline & Reprovações & Como o sujeito se descreveu \\
\hline Álvares & & Sempre o melhor aluno. \\
\hline Beatriz & & Boa aluna. \\
\hline Malik & & Sempre o melhor aluno. \\
\hline Taiko & & Sempre a melhor aluna. \\
\hline Zapata & $\begin{array}{l}\text { Ensino Médio, por faltas, } \\
\text { motivadas pelo trabalho. }\end{array}$ & Bom aluno. Achava a escola pouco desafiadora. \\
\hline
\end{tabular}

No grupo A, 5 dos 8 sujeitos - AK47, André, Frida, Maria e Paula - consideraram ter sido "bons alunos". Frida pareceu tê-lo sido desde os primeiros anos do Fundamental. Os outros 3 sujeitos, a partir do $2^{\circ}$. segmento do Ensino Fundamental. No grupo B, 2 sujeitos descreveram-se como bons alunos e 3 como os melhores alunos da sala ou da escola, desde a alfabetização. Interessante ressaltar que o desempenho escolar desses sujeitos não parece ter estado vinculado ao capital escolar de seus pais - já que as mães de 2 deles nem alfabetizadas eram -, mas ao tipo de investimento que a família fez na escola. No caso de Zapata, a aposta na escola era verbalizada constantemente pela mãe; no de Malik, ela foi assumida pela própria criança como forma de se sobrepor às diferenças de classe social na escola.

Dada a aparente irrelevância das instituições religiosas para a constituição leitora da maioria dos sujeitos de ambos os grupos, ao invés de dedicar um tópico inteiro tais instituições, apresento a seguir algumas considerações apenas sobre duas pesquisadas.

Para Laís e Taiko, que receberam forte educação religiosa de sua família, a mediação de leitura exercida pelas instituições religiosas confunde-se com a da escola. Tal mediação consistiu de estímulo à leitura da Bíblia, análise e interpretação do texto e interlocução com outros leitores sobre seu conteúdo.

Ambas as pesquisadas freqüentaram escolas confessionais na Educação Infantil e no primeiro segmento do Ensino Fundamental e tiveram a Bíblia como seu primeiro material de leitura. Membro atuante do grupo de jovens da Igreja Católica, Laís mantinha, à ocasião da coleta de seu depoimento, profundo interesse por assuntos religiosos, o qual foi sempre um dos principais motores de suas leituras. Taiko, por sua vez, desde muito pequena, assistiu aos cultos da igreja diariamente, ocasião em que se lia e interpretava trechos da Bíblia, algo que acredito ter funcionado como eventos de letramento que contribuíram para o desenvolvimento de suas habilidades de leitura, de compreensão de texto e de expressão oral. 


\subsection{A mediação de leitura no âmbito da biblioteca}

Procuro, neste tópico, analisar a mediação de leitura que se deu no âmbito das bibliotecas escolar, pública e comunitária. O texto de análise foi dividido de acordo com o tipo de biblioteca (escolar, pública ${ }^{93}$ ou comunitária) e novamente subdividido em grupos A (leitores) e B (leitores de literatura). Ao final, apresento a comparação entre os dois grupos.

Embora a biblioteca escolar nas escolas públicas seja uma biblioteca pública, já que é mantida pelo Estado, optei, em nome da clareza da análise, por diferenciá-la das outras bibliotecas públicas.

Optei pelo uso do termo genérico atendente da biblioteca no lugar de bibliotecário, pois nem no contexto da biblioteca escolar nem no da biblioteca pública os sujeitos parecem ter entrado em contato com bibliotecários em si.

Para favorecer a visualização dos dados coletados, disponibilizo nas páginas a seguir quadros sinópticos dos grupos A e B. Para viabilizar a construção dos referidos quadros, adotei algumas abreviações, que lembro abaixo:

BC: Biblioteca comunitária

BCST: Biblioteca Comunitária Solano Trindade

BE : Biblioteca escolar

BP: Biblioteca pública

EF: Ensino fundamental

EM: Ensino médio

FA: Força Ativa

Quando eventualmente nada tiver sido escrito em alguma célula, deve-se compreender que nada de relevante para a constituição do leitor foi dito sobre aquele aspecto específico.

\footnotetext{
${ }^{93}$ Classifiquei como pública a extinta biblioteca do Espaço SESI, freqüentada por um dos sujeitos, embora ela não fosse mantida pelo Estado. A razão disso foi o seu caráter de livre acesso a qualquer pessoa.
} 


\section{MEDIAÇÃO DE LEITURA NO ÂMBITO DA BIBLIOTECA - GRUPO A (Leitores)}

\begin{tabular}{|c|c|c|c|c|c|c|c|c|c|}
\hline Sujeito & $\begin{array}{l}\text { Biblioteca } \\
\text { escolar }\end{array}$ & $\begin{array}{l}\text { Atendente } \\
\text { da } \mathrm{BE}\end{array}$ & $\begin{array}{l}\text { Freqüiên- } \\
\text { cia da } \\
\text { mediação }\end{array}$ & $\begin{array}{l}\text { Biblioteca } \\
\text { pública }\end{array}$ & $\begin{array}{l}\text { Atendente } \\
\text { da BP }\end{array}$ & $\begin{array}{l}\text { Frequên- } \\
\text { cia da } \\
\text { mediação }\end{array}$ & $\begin{array}{l}\text { Biblioteca } \\
\text { Comunitária }\end{array}$ & $\begin{array}{l}\text { Atendente da } \\
B C\end{array}$ & $\begin{array}{l}\text { Freqüiên- } \\
\text { cia da } \\
\text { mediação }\end{array}$ \\
\hline AK47 & $\begin{array}{l}\text { BE } \\
\text { inexistente } \\
\text { com } \\
\text { exceção de } \\
\text { uma série. }\end{array}$ & & & $\begin{array}{l}\text { Apenas uma } \\
\text { biblioteca infanto- } \\
\text { juvenil uma única } \\
\text { vez e só depois de } \\
\text { longa e intensa } \\
\text { mediação na BCST. }\end{array}$ & & & $\begin{array}{l}\text { A BCST é a } 1^{\text {a }} \text {. biblioteca que } \\
\text { conhece com exceção da BE } \\
\text { numa série. A mediação da } \\
\text { BCST confunde-se com aquela } \\
\text { do movimento social FA. }\end{array}$ & $\begin{array}{l}\text { A mediação dos } \\
\text { atendentes da } \\
\text { BCST confunde-se } \\
\text { com aquela dos } \\
\text { membros do FA. }\end{array}$ & $\begin{array}{l}\text { Diária. } \\
\text { Atuou } \\
\text { como } \\
\text { voluntá- } \\
\text { rio } \\
\text { da BCST. }\end{array}$ \\
\hline ANDRÉ & $\begin{array}{l}\mathrm{BE} \\
\text { inexistente }\end{array}$ & & & $\begin{array}{l}\text { Inexistente ou } \\
\text { negativa: percepção } \\
\text { da diferença com os } \\
\text { outros consulentes. }\end{array}$ & Irrelevante. & & Não significativa. & $\begin{array}{l}\text { Não significativa } \\
\text { para sua } \\
\text { constituição como } \\
\text { leitor. }\end{array}$ & Ocasional \\
\hline DANDARA & $\begin{array}{l}\text { BE } \\
\text { inexistente } \\
\text { ou muita } \\
\text { restrição de } \\
\text { acesso. }\end{array}$ & & & $\begin{array}{l}\text { Uma única ida à BP } \\
\text { para fazer um } \\
\text { trabalho escolar. } \\
\text { Mediação } \\
\text { inexistente. }\end{array}$ & & & $\begin{array}{l}\text { A mediação da BCST } \\
\text { confunde-se com aquela do } \\
\text { FA. Incentivo à leitura. . } \\
\text { Incentivo à leitura. Estímulo à } \\
\text { leitura de ciências humanas. }\end{array}$ & $\begin{array}{l}\text { A mediação dos } \\
\text { atendentes da } \\
\text { BCST confunde-se } \\
\text { com aquela dos } \\
\text { membros do FA. }\end{array}$ & $\begin{array}{l}\text { Diária. } \\
\text { Atuou } \\
\text { como } \\
\text { voluntá- } \\
\text { ria } \\
\text { da BCST. }\end{array}$ \\
\hline FRIDA & $\begin{array}{l}\text { BE nas } \\
\text { duas } \\
\text { primeiras } \\
\text { séries do } \\
\text { EF. } \\
\text { Depois } \\
\text { BE } \\
\text { inexistente. }\end{array}$ & $\begin{array}{l}\text { Despertou } \\
\text { interesse } \\
\text { de ler por } \\
\text { prazer. } \\
\text { Experiênci } \\
\text { a positiva } \\
\text { na BE } \\
\text { com a } \\
\text { profa. }\end{array}$ & $\begin{array}{l}\text { Não se } \\
\text { lembra. }\end{array}$ & $\begin{array}{l}\text { Não significativa ou } \\
\text { negativa. BP de } \\
\text { Guaianases apenas } \\
\text { para trabalhos } \\
\text { escolares. } \\
\text { BP Mário de } \\
\text { Andrade uma única } \\
\text { vez, já adulta. }\end{array}$ & Irrelevante. & & $\begin{array}{l}\text { Mediação da BCST confunde- } \\
\text { se com a FA. Incentivo à } \\
\text { leitura. Difusão da concepção } \\
\text { de leitura como forma de } \\
\text { defesa. }\end{array}$ & $\begin{array}{l}\text { A mediação dos } \\
\text { atendentes da } \\
\text { BCST confunde-se } \\
\text { com aquela dos } \\
\text { membros do FA. }\end{array}$ & $\begin{array}{l}\text { Semanal. } \\
\text { Atuou } \\
\text { como } \\
\text { voluntá- } \\
\text { ria } \\
\text { da BCST. }\end{array}$ \\
\hline LAÍS & $\begin{array}{l}\text { Restrição } \\
\text { de acesso à } \\
\text { BE. } \\
\text { Acervo não } \\
\text { circulante. }\end{array}$ & Inexistente & & Irrelevante. & Irrelevante. & & $\begin{array}{l}\text { A mediação da BCST } \\
\text { confunde-se com aquela do } \\
\text { FA. Incentivo à leitura. } \\
\text { Estímulo à leitura de ciências } \\
\text { humanas. }\end{array}$ & $\begin{array}{l}\text { A mediação dos } \\
\text { atendentes da } \\
\text { BCST confunde-se } \\
\text { com aquela dos } \\
\text { membros do FA. }\end{array}$ & $\begin{array}{l}\text { Diária. } \\
\text { Atuou } \\
\text { como } \\
\text { voluntá- } \\
\text { ria } \\
\text { da BCST. }\end{array}$ \\
\hline
\end{tabular}




\begin{tabular}{|c|c|c|c|c|c|c|c|}
\hline MARIA & $\begin{array}{l}\text { EF: BE } \\
\text { inexistente } \\
\text { ou fechada. } \\
\text { EM: BE } \\
\text { aberta, mas } \\
\text { não retira } \\
\text { obras. }\end{array}$ & $\begin{array}{l}\text { Não } \\
\text { significativ } \\
\text { a. }\end{array}$ & $\begin{array}{l}\text { Não significativa ou } \\
\text { negativa. BP para } \\
\text { trabalhos escolares. } \\
\text { Não retira obras. }\end{array}$ & Inexistente & $\begin{array}{l}\text { A da BCST confunde-se com } \\
\text { aquela do FA. Incentivo à } \\
\text { leitura. Estímulo à leitura de } \\
\text { ciências humanas. }\end{array}$ & $\begin{array}{l}\text { A mediação dos } \\
\text { atendentes da } \\
\text { BCST confunde-se } \\
\text { com aquela dos } \\
\text { membros do FA. }\end{array}$ & $\begin{array}{l}\text { Mais que } \\
\text { semanal. } \\
\text { Atuou } \\
\text { como } \\
\text { voluntá- } \\
\text { ria } \\
\text { da BCST. }\end{array}$ \\
\hline MARLEY & $\begin{array}{l}\text { Restrição } \\
\text { de acesso à } \\
\text { BE. }\end{array}$ & $\begin{array}{l}\text { Inexistente } \\
\text { ou } \\
\text { negativa. }\end{array}$ & $\begin{array}{l}\text { Não significativa ou } \\
\text { negativa. }\end{array}$ & Inexistente. & $\begin{array}{l}\text { A mediação da BCST } \\
\text { confunde-se com a da gênese } \\
\text { do FA e da própria BCST. } \\
\text { Incentivo à leitura. Estímulo à } \\
\text { leitura de ciências humanas. }\end{array}$ & $\begin{array}{l}\text { A mediação dos } \\
\text { atendentes da } \\
\text { BCST confunde-se } \\
\text { com aquela dos } \\
\text { membros do FA. }\end{array}$ & $\begin{array}{l}\text { Atuou } \\
\text { como } \\
\text { voluntá- } \\
\text { rio } \\
\text { da BCST }\end{array}$ \\
\hline PAULA & $\begin{array}{l}\text { EF I: BE } \\
\text { inexiste. } \\
\text { EFII e EM: } \\
\text { BE aberta, } \\
\text { acervo } \\
\text { circulante. }\end{array}$ & $\begin{array}{l}\text { Mediação } \\
\text { inexistente } \\
\text { ou } \\
\text { negativa }\end{array}$ & $\begin{array}{l}\text { BP na infância: } \\
\text { experiência muito } \\
\text { positiva. } \\
\text { Biblioteca da Escola } \\
\text { Paulista de } \\
\text { Medicina }\end{array}$ & & $\begin{array}{l}\text { Não significativa (pouco } \\
\text { tempo de contato) }\end{array}$ & $\begin{array}{l}\text { Não significativa } \\
\text { (pouco tempo de } \\
\text { contato) }\end{array}$ & Semanal \\
\hline
\end{tabular}

Legenda

BC: Biblioteca comunitária

BCST: Biblioteca Comunitária Solano Trindade

BE : Biblioteca escolar

BP: Biblioteca pública

EF: Ensino Fundamental

EFI: $1^{\circ}$. segmento do Ensino Fundamental (1 ${ }^{\mathrm{a}}$. à $4^{\mathrm{a}}$. série)

EFI: $2^{\circ}$. segmento do Ensino Fundamental ( $5^{\mathrm{a}}$. à $8^{\mathrm{a}}$. série $)$

EM: Ensino Médio

FA: Força Ativa 


\section{MEDIAÇÃO DE LEITURA NO ÂMBITO DA BIBLIOTECA- GRUPO B (Leitores de literatura)}

\begin{tabular}{|c|c|c|c|c|c|c|c|c|c|}
\hline Sujeito & Biblioteca escolar & $\begin{array}{l}\text { Atendente } \\
\text { da } \mathrm{BE}\end{array}$ & $\begin{array}{l}\text { Freqüiên- } \\
\text { cia da } \\
\text { mediação }\end{array}$ & Biblioteca pública & $\begin{array}{l}\text { Atendente da } \\
\text { BP }\end{array}$ & Freqüência & $\begin{array}{l}\text { Biblioteca } \\
\text { comunitária }\end{array}$ & $\begin{array}{l}\text { Atendente da } \\
B C\end{array}$ & $\begin{array}{l}\text { Freqüiên- } \\
\text { cia da } \\
\text { mediação }\end{array}$ \\
\hline ÁLVARES & $\begin{array}{l}\text { BE inexistente, } \\
\text { fechada ou sem } \\
\text { mediadores. }\end{array}$ & $\begin{array}{l}\text { Não } \\
\text { significa- } \\
\text { tiva. }\end{array}$ & & $\begin{array}{l}\text { Livre acesso e proximidade } \\
\text { física com as obras (música e } \\
\text { livros). } \\
\text { Burocracia em algumas BPs. }\end{array}$ & $\begin{array}{l}\text { Não } \\
\text { significa- } \\
\text { tiva. }\end{array}$ & $\begin{array}{l}\text { Semanal na } \\
\text { infância. } \\
\text { Diária na } \\
\text { adolescência }\end{array}$ & $\begin{array}{l}\text { Troca de } \\
\text { informaçõe } \\
\text { s sobre } \\
\text { leituras. }\end{array}$ & $\begin{array}{l}\text { O grupo FA } \\
\text { fortalece o } \\
\text { leitor }\end{array}$ & $\begin{array}{l}\text { Quase } \\
\text { diária }\end{array}$ \\
\hline BEATRIZ & $\begin{array}{l}\text { EFI: BE inexiste. } \\
\text { EF II e EM: BE aberta, } \\
\text { acervo circulante. } \\
\text { Sociabilidade em torno } \\
\text { da BE. Mediação na } \\
\text { BE pela profa. de LP. }\end{array}$ & Negativa. & $\begin{array}{l}\text { Quase } \\
\text { diária }\end{array}$ & $\begin{array}{l}\text { BP durante } 1^{\circ} \text {. segmento do EF: } \\
\text { não se lembra da mediação, mas } \\
\text { lembra-se de adorar ficar } \\
\text { naquele ambiente lendo } \\
\text { Biblioteca da Escola Paulista de } \\
\text { Medicina }\end{array}$ & $\begin{array}{l}\text { Não } \\
\text { significa- } \\
\text { tiva. } \\
\text { Simpatia. }\end{array}$ & $\begin{array}{l}\text { Semanal } \\
\text { Ocasional }\end{array}$ & & $\begin{array}{l}\text { Simpatia, } \\
\text { mas não } \\
\text { relevante } \\
\text { para seu } \\
\text { interesse. }\end{array}$ & Semanal \\
\hline MALIK & $\begin{array}{l}\text { Mediação inexistente. } \\
\text { BE fechada ou sem } \\
\text { mediadores de } \\
\text { conhecimento. }\end{array}$ & $\begin{array}{l}\text { Inexisten- } \\
\text { te. }\end{array}$ & & $\begin{array}{l}\text { BP Guaianases: não } \\
\text { significativa. } \\
\text { BP Mário de Andrade: mediação } \\
\text { inexistente ou negativa - } \\
\text { percepção da diferença com os } \\
\text { outros consulentes. }\end{array}$ & $\begin{array}{l}\text { Mediação } \\
\text { não } \\
\text { significa- } \\
\text { tiva. }\end{array}$ & Ocasional & $\begin{array}{l}\text { Troca de } \\
\text { informaçõe } \\
\text { s sobre } \\
\text { leituras. }\end{array}$ & & $\begin{array}{l}\text { Rara até } \\
\text { recentem } \\
\text { ente. }\end{array}$ \\
\hline TAIKO & $\begin{array}{l}\text { Mediação não } \\
\text { significativa. Barreira } \\
\text { de acesso }\end{array}$ & Negativa. & & $\begin{array}{l}\text { Só visitou uma e, ainda assim, } \\
\text { de passagem. }\end{array}$ & $\begin{array}{l}\text { Atendimen- } \\
\text { to simpá- } \\
\text { tico. }\end{array}$ & $\begin{array}{l}\text { Uma única } \\
\text { vez. }\end{array}$ & & $\begin{array}{l}\text { Simpatia, } \\
\text { mas não } \\
\text { relevante } \\
\text { para seu } \\
\text { interesse. }\end{array}$ & Semanal \\
\hline ZAPATA & BE inexistente. & & & $\begin{array}{l}\text { Mediação irrelevante ou } \\
\text { negativa, embora freqüentasse a } \\
\text { BP com freqüência }\end{array}$ & $\begin{array}{l}\text { Atendimen- } \\
\text { to mecani- } \\
\text { zado, não } \\
\text { convidativo }\end{array}$ & Freqüente & \multicolumn{2}{|c|}{$\begin{array}{l}\text { A mediação da BCST } \\
\text { confunde-se com a da } \\
\text { gênese do FA e da BCST. } \\
\text { Graduação motivada pelo } \\
\text { pertencimento ao FA e à } \\
\text { BCST. }\end{array}$} & Diária \\
\hline
\end{tabular}


Legenda

BC: Biblioteca comunitária

BCST: Biblioteca Comunitária Solano Trindade

BE : Biblioteca escolar

BP: Biblioteca pública

EF: Ensino Fundamental

EFI: $1^{\circ}$. segmento do Ensino Fundamental $\left(1^{\mathrm{a}}\right.$. à $4^{\mathrm{a}}$. série $)$

EFI: $2^{\mathrm{o}}$. segmento do Ensino Fundamental ( $5^{\mathrm{a}}$. à $8^{\mathrm{a}}$. série)

EM: Ensino Médio

FA: Força Ativa 


\subsubsection{A biblioteca escolar}

\subsubsection{A biblioteca escolar e o grupo A (os leitores)}

No grupo A de leitores, a biblioteca escolar inexistiu, esteve fechada ou ofereceu muita restrição de acesso durante toda ou a maior parte da trajetória escolar de 7 sujeitos. Nos raros momentos em que a biblioteca esteve aberta, o atendimento por ela oferecido foi pouco convidativo, não houve indicações de leitura, o acervo não circulou e os alunos não tiveram autonomia para manusear os livros. Além disso, seu acervo pareceu constituir-se, sobretudo, de livros didáticos e paradidáticos:

AK47: E depois que eu passei da idade escolar, eu não lia mais nada porque você não tem acesso à biblioteca da escola e das escolas que eu passei quando eu entrei na escola, só uma aqui na Tiradentes que eu cheguei a ir na sala de leitura. Nas outras, eu nem sabia que existia biblioteca.

André: Na época, não [tinha sala de leitura na minha escola].

Dandara: Ah, que eu me lembro, acho que não [podiam pegar livros emprestados da sala de leitura da escola]. Acho que não podia levar pra casa, o trabalho tinha que ser feito lá, e a gente só podia ler quando os professores levavam. Eu não sei, eu não lembro se era, se tinha um dia fixo ou alguma coisa assim. Eu só sei que a gente lia o livro lá, aí acabava o horário, você tinha que ler na próxima vez que fosse lá. Você não levava o livro pra casa e terminava de ler ele.

Frida: Não. [A biblioteca das escolas em Cidade Tiradentes] não emprestava os livros. Não emprestava. Tinha também esses momentos de leitura, né, mas eu nunca fui de ir na biblioteca da escola pegar o livro, fazer o trabalho.

Laís: Eu tava com meus 17, 16 anos que eu comecei a pegar livro [na BCST]. Porque antes, como aqui é difícil ter biblioteca, principalmente comunitária, a única biblioteca que tinha era na escola e ela não era muito aberta, na realidade, para os alunos. Eles falavam que era, mas era muito restrita... pra gente pegar livro. [...] Era mais livro didático que eles davam pra gente tirar matéria. Mas pra ler mesmo... No comecinho, teve um momento em que eles deixavam a gente levar o livro... pra casa. Mas sempre tem uns que não sabem o que fizeram, que somem com o livro. Mas daí eles tiraram, porque antes eu também pegava livro na escola. Mas aí eles tiraram. Não tinha como pegar o livro pra você ficar lendo, até pra distrair a mente...

Maria: E porque eu me recordo bem que a escola sempre ficava fechada. A escola, não. A biblioteca da escola sempre ficava fechada, agora eu não lembro direito de... Eu não me recordo [de ir à biblioteca da escola].

Marley: Então, [as práticas de leitura na escola] não [me ajudaram a gostar de ler], porque... falido na escola. E a pessoa responsável por mexer no livro dizia: "Tá cheio de pó". Isso não dá autonomia para o aluno mexer, conhecer. Logo dizia: "Ah, vai bagunçar”. Vinte alunos para ler um livro. Em tudo quanto é escola que eu já fui.

No contexto descrito acima, é desnecessário dizer que a mediação de leitura pela biblioteca escolar em geral e pelo atendente da biblioteca escolar (quando ele existiu) foi pouco significativa ou até negativa. 
Apenas 3 dos 8 sujeitos do grupo A relataram períodos de exceção, em que freqüentaram a biblioteca escolar regularmente. Trata-se de Frida, Maria e Paula. Para 2 dessas 3 entrevistadas - Frida e Paula -, que foram à biblioteca nos 2 primeiros anos do Ensino Fundamental e da $5^{\mathrm{a}}$. série ao $2^{\circ}$. ano do Ensino Médio, respectivamente, a experiência na biblioteca foi extremamente positiva, pois não apenas possibilitou o acesso a material impresso, mas também contribuiu para despertar o interesse (no caso de Frida) ou consolidar a prática (no caso de Paula) de ler por prazer/lazer e ler para a escolarização. As visitas à biblioteca parecem ter ocorrido pelo menos uma vez por semana e a condução de atividades de leitura foi realizada não pelo atendente da biblioteca, mas sim pela professora de Ensino Fundamental e pela professora de Língua Portuguesa:

Frida: [Lá na biblioteca do Jaçanã,] era a professora que levava. Depois você poderia também ir na biblioteca pegar, mas aí eu já não me lembro, porque, como eu era muito nova, eu já não lembro se eu chegava a ir muitas vezes. Mas eu sei que a professora sempre trazia algum livro e tinha dias que era o dia da leitura, então, é uma forma que acho que dá estímulo a ler, né. [Eu] gostava, gostava [de ir à biblioteca]. Lembro mais ou menos [da biblioteca]. Tinha a estante, tinha a mesa, acho que a mesa era redonda, tinha umas cadeirinhas, era um espaço - como se fala? - bem... Bem tranqüilo de ler. E bem organizado também. Era uma escola muito organizada. Eu gostava daquela escola. Era uma escola bem boa, não sei se está boa ainda, mas era muito boa. [Eu] gostava, gostava da professora também.

Paula: Nossa, faz acho que uns cinco anos atrás, a gente gostava [de ler sozinha, sem ser incentivada], desde quando a gente morava lá em Poá. A gente pegava, mesmo quando meus amigos assim não lia, sabe, entrava as férias, assim, aí, a gente não se via. A gente [minha irmã e eu] falava: "Nossa! vamos lavar logo essa louça para ir na biblioteca pegar um livro para nós ficar lendo". [Lá] podia [pegar livros] mesmo nas férias.

$[\ldots]$

E lá em Poá, a gente freqüentava mais a biblioteca da escola. Lá eu lembro de ter biblioteca. [Lá] podia pegar livro, levar para casa... [Na biblioteca, quem nos atendia] era um professor que ficava lá direto. [...] Ele não era simpático, ele não recomendava. Ele simplesmente... Ele só ficava sentado na cadeira enquanto os alunos escolhiam os livros e depois ia lá, e ele anotava e só isso. Mas não recomendava. Não falava nada.

Em síntese, de modo geral, a biblioteca escolar foi um equipamento ausente da história da maioria dos leitores do grupo A. Todavia, para os poucos sujeitos que a freqüentaram, ainda que durante períodos curtos, a biblioteca assumiu grande relevância para sua constituição.

\subsubsection{A biblioteca escolar e o grupo B (os leitores de literatura)}

Quatro dos 5 sujeitos do grupo B - Álvares, Beatriz, Malik e Taiko - puderam freqüentar a biblioteca com certa regularidade por períodos mais longos que os sujeitos do grupo A: Malik durante 3 anos, Álvares, Beatriz e Taiko, durante 6 ou 7 anos. Porém, vários dos problemas elencados quando da análise do papel da biblioteca escolar na história dos 
sujeitos do grupo A - atendimento pouco convidativo, restrições de circulação de acervo, não indicação de leituras - se fizeram presentes também na trajetória dos sujeitos do grupo B:

\begin{abstract}
Álvares: Aí, eu pegava os livros da escola: eu estava na terceira série, eu pegava livros da quinta, sexta, sétima série para eu ver o que ia ter depois. Eu sempre pegava livros assim, estava na quarta, pegava da quinta assim. [Eu pegava] na biblioteca da escola os livros paradidáticos. [...] A primeira escola foi no Jabaquara, [...] depois aqui na Cidade Tiradentes. E as escolas... a biblioteca sempre fechada, sem mediadores de conhecimento nas bibliotecas da escola, e quando era aberta não tinha ninguém para mediar conhecimento, os livros paradidáticos, os livros de literatura pouco específicos.
\end{abstract}

Malik: Daí, já passava a freqüentar a sala de leitura da escola [na região do Aricanduva]. Lá era aberto. [...] Ia com a professora. Não levava livro para casa. A professora levava a galera e ficava um monte de gente e aí não tinha leitura nenhuma. Ela dizia: "Você vai lá e pega o que você quer". Tinha acho que um dia específico para ir para a leitura. Não me recordo bem das ocasiões que nós íamos para a sala de leitura, mas não havia cobrança de alguma forma de avaliação da leitura. A gente ia lá para... Mas não havia indicação de leitura mesmo, que te indicasse para algum caminho. Então, eu lembro logo de cara assim, era na terceira série que eu freqüentava a sala de leitura, de: Moby Dick, era o livro que eu li. Não era da Coleção Vaga-lume, mas era parecido...

[A biblioteca da escola do Tatuapé] era fechada Eu fui na biblioteca da escola duas vezes só nos três anos que estive lá. Eu fui lá só para procurar um livro para fazer um trabalho e nem encontrei. Era difícil consultar. Fui duas vezes só, duas ou três vezes.

Taiko: E, quando a pessoa gosta, quando tem aqueles cinco, três, dois, ou um na escola que gosta de ler, eles proíbem. Eles... No meu caso, eu gostava de levar livros, bastante livros para eu ler, eu devorava um livro em um dia, bastante livro, eu gostava, e entregava e pegava mais. Uma fome insaciável de ler livros. Aí, elas não gostavam que eu pegava. Foi uma luta, porque elas falavam assim, "Não podemos mais emprestar livros porque os alunos do ano passado, retrasado, não trouxeram os livros para cá, emprestaram e não devolveram". Então, elas achavam que eu tinha o mesmo caráter que as outras pessoas, mas eu mostrava diferente pra elas, entendeu? Aí, teve uma hora que isso acabou. Aí, elas aprenderam a gostar de mim, a me emprestar os livros e tudo ficou numa boa. Mas agora eu não pego mais livros emprestados lá, porque está fechada, nem a minha irmã mesmo pega. [Na escola em que eu] estudava. Na que eu estudo agora, também tinha esse mesmo problema. Os alunos da minha sala não podiam pegar, não sei o porquê, acho que por causa do mesmo motivo. Por causa de um, todos sofrem. Aí, eu fui lá, comecei por mim mesma, fui influenciando meus colegas, falando "Eu tô pegando livros emprestado na biblioteca". A partir do momento que eu fui pedir pra ela, ela deixou emprestar, e aí, todo mundo começou a emprestar livro. [...] Acho que foi por causa do meu interesse e por causa da minha persistência [que ela me deixou pegar livros emprestados]. Eu irritava, eu batia na porta, corria atrás dela, perguntava "E aí, não vai abrir a biblioteca, não?". Aí, quando a biblioteca estava aberta, eu ficava escolhendo os livros, colocava na mesa e falava assim: "Eu quero levar esses livros", entendeu, e ela... Eu até falei com os professores: "Como é que pode uma escola não poder pegar livros emprestados?". Eu ficava revoltada por causa disso.

Zapata, o quinto componente deste grupo, nunca estudou numa escola com biblioteca.

A mediação de leitura pelo atendente da biblioteca escolar foi irrelevante ou negativa.

Malik e Beatriz freqüentaram a biblioteca regularmente da $3^{\mathrm{a}}$ à $5^{\mathrm{a}}$. série e da $5^{\mathrm{a}}$. série ao $2^{\mathrm{o}}$. ano do Ensino Médio, respectivamente. Suas experiências foram extremamente positivas, pois não apenas possibilitaram o acesso a material impresso, mas também contribuíram para despertar o interesse (no caso de Malik) ou consolidar a prática (no caso de ambos) de ler por prazer/lazer. A mediação de leitura no espaço da biblioteca escolar, no caso de Malik, parece ter sido pouco significativa. Ainda assim, as visitas à biblioteca foram essenciais para sua constituição como leitor, pois lhe permitiram a leitura de material impresso para além de 
gibis, em especial, obras de literatura infanto-juvenil, às quais o sujeito não teria tido acesso via família ou biblioteca pública:

Malik: Então, eu lembro logo de cara, assim, era na terceira série que eu freqüentava a sala de leitura, de: Moby Dick, era o livro que eu li. Não era da Coleção Vaga-lume, mas era parecido. [...] Leitura infanto-juvenil com títulos clássicos. Títulos para os da minha época assim: Passageiros do Futuro, A Ilha Perdida, A Primeira Reportagem, esses os livros que eu li. Açúcar Amargo, um clássico que até hoje na faculdade, eu reli esse livro porque ele é muito legalzinho. Acho que essa coleção iniciou uma boa parte de quem lê um pouquinho, começou com essa Coleção Vaga-lume... [que eu li] da terceira série até a sexta, sétima. Até a sétima série mais ou menos... [Em casa, eu lia] gibi.

Em ambos os casos, a atuação do atendente da biblioteca foi pouco significativa ou negativa:

Beatriz: [O atendente da biblioteca da escola de Poá era] completamente antipático! Você entrava lá, nem oi ele falava para você. Só anotava mesmo o que entrava e saía. E mais nada.

A existência da biblioteca escolar e a possibilidade de visitá-la estiveram vinculadas à localização da escola: quanto mais antigo e central fosse o bairro, maiores as chances de a biblioteca escolar existir e funcionar melhor. Mudar-se para Cidade Tiradentes significava deixar de ter acesso a tal equipamento.

Resumindo, a maior parte dos sujeitos do grupo A fizeram uso da biblioteca escolar, mas não durante toda a escola básica e sempre com problemas na sua mediação de leitura. Ainda assim, o acesso a material impresso que ela possibilitou foi essencial para a constituição leitora de 3 sujeitos - Beatriz, Malik e Taiko.

\subsubsection{A biblioteca escolar: comparando os grupos A e B}

$\mathrm{Na}$ trajetória tanto dos sujeitos do grupo A quanto daqueles do grupo B, houve restrição de acesso à biblioteca escolar e de circulação do acervo durante toda a escolarização básica ou durante longos períodos. Os relatos evidenciaram também que, quando a biblioteca esteve aberta, a mediação de leitura foi irrelevante ou precária para a maioria. Apesar disso, os depoimentos de 6 sujeitos ${ }^{94}$ que fizeram, em algum momento, leituras na biblioteca para além daquelas estritamente ligadas ao cumprimento de alguma tarefa ou ao ato de "tirar matéria" de livros paradidáticos apontam também para a grande importância desse equipamento para a constituição leitora deles.

\footnotetext{
${ }^{94}$ Trata-se de Álvares, Beatriz, Frida, Malik, Paula e Taiko.
} 
Se os sujeitos dos grupos A e B guardam as semelhanças apontadas acima, por outro lado, apresentam entre si uma diferença importante: de modo geral, os sujeitos do grupo B parecem ter tido mais acesso à biblioteca escolar.

\subsubsection{A biblioteca pública}

\subsubsection{A biblioteca pública e o grupo A (os leitores)}

No grupo A, a grande maioria dos sujeitos não utilizou a biblioteca pública durante toda a escola básica, a não ser para realizar eventuais trabalhos escolares. A mediação de leitura nesse espaço foi considerada pouco significativa ou negativa.

Dentre os 8 leitores do grupo A, um - AK47 - nunca havia visitado uma biblioteca pública até o encerramento do Ensino Médio. Dandara o fez uma única vez. Os quatro outros sujeitos - André, Frida, Laís, Maria e Marley - foram à biblioteca pública muito raramente durante a infância e adolescência. Na maioria dos casos, fizeram-no apenas para realizar pesquisas para trabalhos escolares e não chegaram a tomar livros emprestados, devido à documentação exigida, à distância entre a biblioteca e suas casas ou ao simples fato de não se sentirem atraídos para ler algo para além do estritamente necessário para atender às exigências da escola:

AK47: E o meu contato com a biblioteca, só fui uma vez na biblioteca pública, uma infanto-juvenil, depois que eu tive contato com essa biblioteca comunitária [BCST]. De resto, nunca tinha pisado numa biblioteca pública. Então, o acesso que eu tinha a livros, no período escolar, não tinha nenhum.

André: Fui algumas vezes [à biblioteca pública], para fazer trabalhos escolares, mas era bem aquele negócio: trabalho de escola, não tinha dinheiro, pessoal está todo trabalhando e eu estava desempregado. Então, eles me davam o dinheiro da condução e eu ia, pegava os livros e aí ficava duas, três horas, quatro horas fazendo o trabalho, elaborando o trabalho, pesquisando em algum livro sobre um tema para trazer e cada um fazia a sua parte, um xerocava, passava a parte dos companheiros... [Eu] não [pegava livros emprestados], porque, se eu pegasse, eu não ia devolver, porque eu não tinha dinheiro para ir daqui até a biblioteca e a biblioteca mais próxima que tinha era a de Guaianases.

Dandara: Essa [a BCST] foi a primeira [biblioteca] que eu vim, pra entrar em uma biblioteca, acho que foi a segunda assim. [A primeira] foi uma que tinha, não sei se ainda tem no... Guaianases. Acho que é pública. [...] Eu estava no fundamental ainda, nem me lembro. Ah, nem lembro [minha idade quando eu fui lá].

Frida: Eu nunca fui de ir na biblioteca da escola pegar o livro, fazer o trabalho. Eu sempre fui em biblioteca fora. Então, por exemplo, eu ia em Guaianases, que é a biblioteca que eu lembro na época. E agora tem umas mais próximas, assim, pública. Mas naquele tempo era só a de Guaianases, que eu me lembre. Aí, eu ia lá fazer trabalho. [...] Eu só não pegava livro para ler, era mais para fazer trabalho. E aí, já foi o momento que distanciou da leitura, né. É, porque aí, como você só vai pra aquela finalidade de pegar o livro pra fazer o trabalho, não é uma coisa que é só pra você ler por prazer porque você gosta, né? 
Maria: Então, tem uma biblioteca pública ali em Guaianases. Aí, eu lembro que, nos momentos de desespero, "Eu tenho que entregar trabalho", alguma coisa, a gente sempre ia até lá. Mas, nossa, eu não me lembro de ter pego nenhum livro lá, não. Não sei se era documento... Uma vez ia, mas não tinha documento. Outra vez é... com problema de receita. Eu lembro que sempre tinha alguma coisa e aí eu passei a não ir mais lá. De biblioteca pública, só essa que eu fui, nenhuma outra.

A exceção à regra de não frequiência regular à biblioteca pública foi Paula, que visitou uma localizada em Vila Formosa semanalmente até cerca de 10 anos de idade.

Cabe ressaltar que, dos 8 sujeitos do grupo A, apenas 3 - André, Marley e Paula visitaram em algum momento a biblioteca pública por motivações de ordem pessoal, para ler por lazer ou para obtenção de conhecimento, e não para fazer trabalhos escolares. Paula o fez na infância com a família. André e Marley o fizeram muito raramente e já na adolescência.

$\mathrm{O}$ atendimento ao consulente na biblioteca pública foi considerado pela vasta maioria dos sujeitos como impessoal ou pouco convidativo. Isso se deu mesmo no caso de AK47 sujeito que entrou na biblioteca pública pela primeira vez já depois de adulto - e de Frida que, também já adulta, visitou pela primeira vez uma biblioteca pública para além da de Guaianases. A mediação da leitura no espaço da biblioteca pública foi muito pouco significativa para os 7 sujeitos, alguns dos quais se ressentiram não apenas da falta de liberdade para manusear os livros, mas também do despreparo dos atendentes, ou da falta de uma postura mais pró-ativa para investigar e perceber quais eram os interesses dos consulentes:

\begin{abstract}
AK47: Então, eu fui lá na Mario de Andrade só que tinha uma palestra, primeira vez que eu entrei na Mario de Andrade e nunca mais entrei, não. Eu entrei lá para fazer uma palestra. Primeiro, fui assistir, depois, eu fui fazer. Duas vezes que eu fui na Mario de Andrade. Não sei que tipo de livro que tem lá, como que faz para pegar livro, lá. Só sei que não sei se é uma biblioteca ou um museu, que as pessoas não podem nem relar num livro. Eu fui na biblioteca Juvenil Monteiro Lobato lá na General Jardim. E lá, eu fui fazer minha carteirinha e eu nunca tinha feito uma carteirinha numa biblioteca pública e lá eu achei bem diferente da Mario de Andrade. [...] Lá, eu achei bem diferente porque eu pude ter contato com o livro e escolher o livro que eu queria levar, embora tenha aquela questão do balcão, os funcionários ficam ali atrás, gente que não te dá muitas instruções, não te dá indicação de livro, não conversa sobre nada em relação à leitura. Porém, eu nunca mais fui lá. Só fui devolver o livro e eu achei que nunca mais fui lá porque não foi uma coisa que me chamou a atenção naquela biblioteca.
\end{abstract}

André: Voltando a falar na biblioteca, a biblioteca pelo fato de ela estar sempre muito cheia - a Mário de Andrade - e não tem um assunto que você pegaria $X$ para ler... [Eu ficava meio perdido] porque é gigantesca, né. [Eu não me sentia bem atendido] porque ele [o atendente] falava: "Você sabe o que você quer?". Eu dizia: "Não, eu queria ler alguma coisa". Então, ele dizia: "Senta, pensa com calma".

Frida: Eu já fui naquela Mario de Andrade, mas aquela biblioteca é muito estranha. Eu entrei uma vez e não entrei mais, porque eu acho que ela não é atrativa para ler. $O$ jeito, não sei se é porque ela é antiga, eu acho que... as pessoas não podem ter o contato com os livros. Você entra, pede tal livro, a pessoa vai lá procurar e traz para você ler, você não mexe no livro, você não procura o livro. Alguém vai lá fazer isso por você. Isso não faz você abrir... Às vezes, você está pensando numa coisa e vê outra, aí, você se interessa, tem curiosidade, né. ,aquela biblioteca, eu não achei isso. Não sei se mudou, mas quando eu fui tava assim. [...] Já tem uns quatro anos [que eu fui lá]. É, já faz um tempinho [risos], mas eu fui só uma ou duas vezes e não fui mais. 
Marley: Cheguei lá na bibliotecária e disse: "Você tem alguma coisa aí sobre negros?". E a bibliotecária [perguntou]: "Mas o quê?". [E eu respondi:] "Qualquer coisa". E a bibliotecária [me disse]: "Qualquer coisa não tem. Você tem que vir com um tema". [Eu respondi] "Ah, não sei”". [E a bibliotecária me disse]: "Ah, então, não tem”. Aí, eu fiquei mais bravo... [Isso aconteceu na] Mário de Andrade. [...] Ah, [a biblioteca pública] está lá. Se você quiser, vai lá. Não tem um "chega" assim até você. Ah, Biblioteca Mario de Andrade, muitos livros, muito boa. Não tem uma conexão com a periferia, para quem mora longe do centro, alguma coisa nesse sentido, intercâmbio. Uma coisa móvel para facilitar. Tudo distante, muito distante.

Apenas 1 dos 7 pesquisados classificou o atendimento do profissional da biblioteca como bom. Porém, tal atendimento não foi suficiente para deixá-lo à vontade face às diferenças de classe social entre os consulentes da biblioteca pública:

André: E, geralmente, era uma senhora negra que me atendia, muito simpática por sinal, então, ela dizia: "Pensa, pensa no assuntinho". E aí, às vezes, eu dizia o assunto e ela trazia um livro e perguntava: "Você quer ver mais alguma coisa?". E trazia mais dois livros, deixava ler à vontade... [Eu me sentia acolhido] pela atendente... Mas pelo público que freqüentava lá, não. As pessoas que freqüentavam lá, você via que eram pessoas garbosas, glamorosas, bem arrumadas, pessoas que geralmente você via eram brancas e já te olhavam meio assim (torto), porque como se vestia boy? Tênis, jeans, camiseta e moletom e uma pastinha embaixo do braço. Eu não gostava muito de boné, então, eu deixava meu cabelo meio blackinho. Então, te olhavam meio assim torto e, às vezes, ficavam te olhando de longe. Então, te inibia ficar muito tempo ali. Porque ali você respira livros e você sentia a intelectualidade naquele ambiente. Agora, no sebo, não. No sebo, vai tanto a tiazinha, a mulher que faz café, como um boy, como um empresário de terno e gravata. Então, eu parava assim e pensava: "Eu sou mais um e tal". Então, é essa a grande diferenciação. [...] As [bibliotecas] públicas que no caso eu fui algumas vezes, elas até têm informação. Acho que o que falta muito é a população criar o hábito de ler livro e tal. É realmente analisado o fato de você ir numa biblioteca, as pessoas sentem assim: "As pessoas estão me olhando de modo diferente. O que eu estou fazendo aqui? Sobre o que eles estão falando?”. Quer dizer, a pessoa se sente meio inibida. Só entra na biblioteca quando tem que fazer um trabalho escolar.

Em síntese, a postura pouco acolhedora das bibliotecas públicas aliada à falta de domínio dos protocolos de leitura naquele ambiente, à sensação de não pertencimento àquele espaço devido às diferenças de classe social, além da própria distância entre o local de moradia e a biblioteca, desfavoreceram a frequiência a ela, em especial, daqueles sujeitos que nunca a haviam visitado na infância ou que tinham se limitado a fazer eventuais trabalhos escolares na biblioteca de Guaianases.

\subsubsection{A biblioteca pública e o grupo B (os leitores de literatura)}

A maioria dos sujeitos do grupo $\mathrm{B}$ fez uso de bibliotecas públicas durante praticamente toda a escola básica e não apenas para realizar trabalhos escolares. Porém, a mediação da leitura na biblioteca foi considerada negativa pela maior parte deles.

Dentre os 5 sujeitos do grupo B, ao menos 3 - Álvares, Beatriz e Zapata freqüentaram algumas bibliotecas públicas durante a infância, em parte devido ao fato de os 
três sujeitos terem residido em bairros mais antigos e menos periféricos (Jabaquara, Vila

Formosa e Itaquera, respectivamente), os quais dispunham desse equipamento:

\begin{abstract}
Álvares: Eu lembro muito do Asterix, Asterix grande, que eles escreviam a nanquim. Eu lembro que ele falava: "Bebemos tantos litros de cerveja e tantos litros de nanquim gastamos no Império Romano". [Nessa biblioteca] lá no Jabaquara. No Jabaquara, tinha uma biblioteca que eu não me recordo o nome, que eu morei no Jabaquara até os... mais ou menos até os doze anos, no Jabaquara, até os catorze anos eu morei no Jabaquara, ali perto do metrô Jabaquara, na zona sul. Então, lá tinha uma biblioteca próxima, era bem próxima... Era [uma biblioteca pública]. Era bem melhor, era até perto do Metrô, de fácil acesso, biblioteca enorme. Eu tinha uns contatos lá, então, tipo Asterix eu lia, só podia ler Asterix, para fazer trabalho de escola, eu ia pra ler, que falava do Império Romano, fala sobre... Que aí também eu li Asterix, cheguei a ler gibi.
\end{abstract}

Beatriz: Eu gostava muito de ir na biblioteca. A gente só podia ir no final de semana com minha irmã, porque ela estudava em horário diferente que o nosso. E a gente, acho que estudava de manhã e ela já estudava à tarde. E a escola dela era longe e ela tinha que sair cedo, não dava para ela levar a gente pra biblioteca, mas ela levava de final de semana. Porque a gente primeiro conversava com a nossa mãe: "Mãe, fala pra Flávia levar a gente pra biblioteca". Aí, minha mãe pedia e ela levava a gente na biblioteca da Vila Formosa, que era perto da nossa casa, e aí a gente passava a tarde lá. Se não pudesse levar pra casa, a gente ficava a tarde lá lendo. E a gente pegava mais livro infantil porque a gente era muito pequenininha naquela época. Mas eu gostava muito de ir na biblioteca de lá. [Eu gostava porque] lá era muito legal. Tinha muito livro e a gente ficava muito eufórica para ler lá. Por isso que eu gostava muito de ir naquela biblioteca. E a companhia das minhas irmãs me fazia sentir bem. Porque a gente, eu e a Paula, a gente sempre ficou junto, mas a Flávia e a Andréa a gente não ficava. A gente não fica muito junto. Eu gostava muito de ir na biblioteca com elas, eu me sentia bem na biblioteca, porque a gente só lia com as minhas irmãs na biblioteca. Na biblioteca da Vila Formosa.

$[\ldots]$

[Essa outra biblioteca não tinha uma seção] para criança, não. [...] Depois que a gente ficou maior, aí, ela levava a gente na biblioteca com ela, para gente escolher um livro para nós e ela escolher um livro para ela. [Essa biblioteca] não era muito grande, não. Mas tinha muito livro. Não tinha espaço para ler lá. Tinha que ir, escolher o livro e levar pra casa pra ler em outro lugar mesmo porque lá não tinha espaço.

Quatro sujeitos - Álvares, Malik, Taiko e Zapata - visitaram bibliotecas públicas durante a adolescência, com diferentes freqüências: Malik e Taiko mais esporadicamente; Zapata regularmente; e Álvares durante (incríveis!) 6 horas diárias dos 14 aos 17 anos. Para 2 sujeitos - Álvares e Malik -, o acesso às bibliotecas públicas foi favorecido quando eles passaram a sair todos os dias de Cidade Tiradentes, por terem entrado no mercado de trabalho formal, aos 14 anos, no centro de São Paulo. Quando Álvares ficou desempregado devido à iminência de ter de servir o exército, continuou, sob pretexto de procurar trabalho, a deslocarse para o centro da cidade e a fazer uso das bibliotecas.

De acordo com os relatos, os 5 sujeitos que visitaram bibliotecas públicas fizeram-no não apenas para realizar pesquisas para trabalhos escolares, mas também para fazer leituras com uma motivação de ordem mais pessoal:

Álvares: Com 14 anos de idade, eu comecei a trabalhar. Eu era office boy e, como todo office boy, eu ia no fliperama jogar fliperama, só que eu fui office boy na Avenida Paulista. Tinha a biblioteca do Espaço SESI, bem perto do Trianon MASP. [...] Não tem mais biblioteca, só tem teatro. Eliminaram a 
biblioteca. [...] Aí, eu fazia o serviço em duas horas, almoçava e ficava o dia todo, quase todos os dias durante vários anos dentro da biblioteca. [...] Eu fui primeiro lá por causa do acesso ao computador, lá onde a gente almoçava, tinha várias televisões. Aí, eu colocava fitas sobre orquestras, sobre pintura, sobre não sei o quê e aí colocava a fita e ficava assistindo com o fone de ouvido sobre orquestra. Aí, me interessou música e eu estudei muito sobre ópera, principalmente sobre Bach, sobre ópera mesmo. Eu gosto muito de ópera. Eu li muito sobre ópera. Li sobre Strauss, sobre Bach, Beethoven e me apaixonei por música. Eu queria tocar alguma coisa. Eu só ouvia Beethoven. Aí, de música eu pegava sobre Renascimento. Me apaixonei sobre Leonardo Da Vinci, queria saber de onde vinham os renascentistas e todos os iluministas e tal. E queria saber quem foi o Michelangelo e tal, como ele pintou e tal. E foi assim: li sobre jardinagem, sobre tatuagem, li sobre tatuador, li sobre tudo que há na biblioteca convencional. É uma biblioteca muito específica. Então, eu li sobre teatro, eu li sobre música, eu li sobre pintura, eu sou apaixonado sobre pintura, teatro, música e muitas coisas. E para eu entender, eu tinha que ler História e... literatura. Então, literatura para eu ter acesso eu tinha que entender muito de História...

Malik:. Uma vez, trabalhando, no ano de 2001, eu estava cansado daquela droga daquele trabalho que me explorava demais e saí para fazer uma entrega na Rua da Consolação. E aí,eu passei em frente à Mário de Andrade. Aí, eu fiz a entrega, aí, voltei correndo e entrei. Daí, entrei na Mário de Andrade e pedi um livro sobre Zumbi dos Palmares. Eu queria ler sobre o Zumbi dos Palmares. Me deram uma enciclopédia, li mesmo uma enciclopédia e fiquei um tempo lá lendo. Tomei uma chamada do chefe, mas valeu a pena.

Zapata: Embora, quando a tiazinha [da biblioteca pública] foi buscar os livros [na minha casa], já não era para trabalho de escola. [Estava] muito atrasado. Na verdade, acho que eu não queria devolver [os livros].

\section{O atendimento ao consulente na biblioteca pública foi considerado por 3 dos 5 sujeitos}

- Álvares, Malik e Zapata - como burocrático, impessoal, pouco convidativo e às vezes antipático. Não houve qualquer atuação no sentido de incentivar a leitura ou de abrandar eventuais dificuldades:

Álvares: Eu pegava na biblioteca porque eu trabalhei na Paulista eu tinha acesso à da Consolação. Tinha a da Consolação e a Mário de Andrade na Xavier de Toledo. Eu só vivia lá. Tinha a maior burocracia, tinha que entrar, pegar o papel, escrever o livro que você quer, eles pegam um livro ou dois e a cadeira certa com o número e eu ficava lá... o maior silêncio.

[...]

Não, [nenhum atendente de biblioteca pública ou escolar contribuiu para eu me tornar leitor]. Depois que eu entrei na universidade, se você falar que você está na universidade, as pessoas te tratam diferente. É lógico, tem todo esse conceito. Aí, as pessoas são diferentes. $[\ldots]$

Ah, eu acredito assim: a falta do Estado de mediar o conhecimento faz com que as pessoas só vão na biblioteca quando tem de fazer trabalho escolar. E as bibliotecas são separadas assim: biblioteca para primeiro grau, segundo grau. E aí, você acaba se surpreendendo com biblioteca que só lê criança e outra só para adolescente, na mesma faixa etária, por um lado. E por outro, você já vem com o livro que a pessoa pede e eles mesmo pegam e jogam os livros na sua mão, você faz o trabalho e vai embora. Eles não falam "vamos ler outro livro, não ler só pra estudar".

Zapata: Mecanizado, o atendimento [na biblioteca]. Aquele salão branco e a indicação de o livro está em tal lugar e você vai lá e pega. Sem contato nenhum. O atendente da biblioteca é funcionário público, aquele clássico de mau humor, nervoso. Sempre foi né.

$[\ldots]$

[A biblioteca pública lá de Itaquera] não foi [importante para mim]. Você sabe que eu fui e fiz um trabalho do índio uma vez. E aí, não é que é maltratado, mas não tem aquela coisa de "Ô volta aí para ler e tal". 
Malik: Não, [o atendimento da biblioteca Mário de Andrade] não é acolhedor, não. Pelo menos, não foi naquele momento. Agora, passa por uma reforma a Mário de Andrade. Eu passei lá em frente outro dia, achei meio estranho, muito frio. Aí, a mulher me traz lá, provavelmente tinha outros autores que falavam, tem outros autores que falam do Palmares que eu já li, mas ela me traz uma enciclopédia. E enciclopédia é tudo muito resumido, duas páginas. Daí, eu li aquelas informações básicas de que Palmares caiu, foi formado no ano de 1600, muito limitado. Por exemplo, se tem um mínimo de diálogo, ela ia saber que aquelas informações eu já tinha. Eu queria ler outras coisas mais aprofundadas sobre Palmares. A obra do Nelson Freitas, do Edson Carneiro, ela poderia ter me indicado, mas foi muito frio: "Deixa sua mochila, entra, não faz barulho, se precisar tirar xérox vai ali". Muito frio.

Da mesma forma que aconteceu com André, sujeito do grupo A, o atendimento dado a Malik não pareceu ser suficiente para deixar o sujeito à vontade face às diferenças de classe social entre os consulentes da biblioteca pública. A despeito disso, ele freqüentou, depois do encerramento do Ensino Médio, outras bibliotecas públicas, como a do Centro Cultural Vergueiro.

Malik: Burocrático e as pessoas não pareciam comigo nem um pouquinho. Nem um pouco. Só tinha brancos. E com certeza todos que estavam ali, hoje, conhecendo os universitários, eram universitários. O estilo roupinha, o cabelo meio jogadinho, esse perfil de estudante é que estava lá. Daí, era estranho até. Eu estava lá com o uniforme da loja. Entro lá no meio daquela playboyzada toda. É uma biblioteca fria, mas acho que tem o maior acervo de São Paulo. Do Brasil, né.

Supomos que o fato de se visitar bibliotecas públicas na infância tenha favorecido domínio dos protocolos de leitura e a sensação de pertencimento. Assim, sujeitos como Álvares e Zapata parecem ter se ressentido menos da sensação de deslocamento. As críticas que fizeram sobre a mediação nesse espaço disseram respeito à sua precariedade, mas não à sensação de ser um estranho.

Se, por um lado, Álvares se ressentiu da falta de mediação significativa pelo atendente da biblioteca, por outro, numa biblioteca específica - a do Espaço SESI - o sujeito teve a possibilidade de andar entre os livros e, em suas palavras, "ser achado por eles", ao invés de escolhê-los, como se eles com ele flertassem. Tal possibilidade, aliada ao imenso número de horas que pôde passar lá dentro, e às leituras que já tinha realizado antes, fizeram-no ampliar ainda mais o seu já bastante abrangente repertório cultural. Não por acaso, para ingressar no Ensino Superior, Álvares, ao contrário da maioria dos outros sujeitos, não teve de recorrer a cursos pré-vestibulares. 


\subsubsection{A biblioteca pública: comparando os grupos A e B}

Na sua relação com a biblioteca pública, os sujeitos do grupo B guardam semelhanças com os do grupo A quanto ao fato de ter começado a freqüentá-la para realizar trabalhos escolares e a algumas críticas que fazem à mediação de leitura pela instituição.

Mas há também diferenças significativas que dizem respeito ao fato de a ela terem ido por iniciativa própria, para realizar leituras de seu próprio interesse e a uma maior freqüência à biblioteca pública pelos sujeitos do grupo $\mathrm{B}$, favorecida pela localização de suas casas ou de seu trabalho.

\subsubsection{A biblioteca comunitária}

Em Cidade Tiradentes, havia, por ocasião das entrevistas, algumas outras bibliotecas comunitárias para além da BCST. No entanto, elas não conseguiram atrair os sujeitos desta pesquisa devido ao fato de cobrarem pela inscrição do consulente, pelos empréstimos, por terem um acervo pouco interessante ou por não interagirem com os usuários de modo a seduzi-los para ler. Por outro lado, a BCST teve um papel fundamental na constituição de vários dos leitores por nós pesquisados. Sendo assim, optei por analisar a mediação de leitura que se deu apenas na BCST e não no conjunto das bibliotecas comunitárias do bairro.

\subsubsection{A biblioteca comunitária e o Grupo A (os leitores)}

Os relatos dos sujeitos explicitaram que a mediação de leitura no âmbito da BCST teve características diametralmente opostas àquelas da mediação nas bibliotecas escolares e públicas.

Ao descrever o atendimento recebido inicialmente na BCST, os sujeitos aludiram à simpatia, à liberdade de manipular o acervo, à demonstração de interesse pelas leituras realizadas por eles e por sua compreensão, às provocações à reflexão, ao auxílio quanto a dificuldades, à disseminação de conhecimentos, ao forte incentivo à leitura e à indicação de obras, justamente os aspectos de cuja falta os sujeitos de ambos os grupos haviam se ressentido nas bibliotecas pública e escolar:

Laís: [Os mediadores da BCST] davam muita atenção para a gente. Eles perguntavam: "O que você entendeu do livro?". E a gente ficava toda sem graça. E perguntavam: "Vocês leram o livro?". E minhas colegas mesmo falavam que aí a gente gostava mesmo de ler o livro e as minhas amigas gostavam de 
vir. [Elas] gostavam porque era gostoso, porque faziam perguntas: “O que ela leu?". "O que ela entendeu?". Aí, vai mudando um pouco a idéia assim, porque o professor só passa como matéria e você vai lendo em outros lugares e tem outras pessoas interessadas no que você está aprendendo e vida vai mudando, né. Porque, aí, as pessoas estão apostando um pouco na vida dos jovens, na leitura e aí que eu gostei mais, já ia pegar livro na biblioteca, fazer certas perguntas também, já que eu não entendia vou perguntar para quem entende. E aí, você conhece mais livros, mais autores. Ah! deixa eu ver: Ah, o Wilson também, ele quando me viu, ele fez a pergunta, né: "O que eu entendi sobre o mundo subdesenvolvido?". Aí, ele perguntou toda questão geográfica para mim e eu falei: "Não sei, sou muito nova para saber tudo isso". [...] E quando ele perguntou isso para mim, e ele é muito comunicativo, o que ele pode passar para a pessoa ele passa. E eu não sou muito de ficar falando, principalmente essa parte séria e ele me chamou num canto e começou a falar sobre a parte global, e eu falei: "Ah, eu estou entendendo, mas acho que sou muito nova para entender do assunto e isso aí eu vou entender mais conforme o tempo". Aí, depois que ele falou aquilo para mim, eu fiquei pensando no aquecimento global, no mundo subdesenvolvido e que o Brasil é o terceiro e, aí, eu comecei a ter conhecimento que o mundo não só gira só no bairro, o que aconteceu nos EUA referente à Bolsa de Nova York, os dólares, vai influenciar no Brasil também. Agora, eu falo que hoje eu tenho noção um pouco mais porque, se ele não fizesse essas perguntas, e ele fez pergunta assim sobre Angola, e ele fez para mim, né. Eu disse: "Temos descendência". E a minha mãe veio falar para mim: "Ele falou isso?", E eu disse: "O que é que tem? Nós temos descendência, né”. E aí, esses pontos sobre a minha religião, a minha cor, eu queria entender um pouco mais".

Maria: No primeiro dia que eu vim aqui, eu fiquei conversando bastante com o pessoal [os mediadores da BCST]. E aí ,eles falaram... também falaram assim, mais ou menos na mesma linha que meu vizinho falava, conversava comigo... Assim, muita pergunta. Sempre colocaram muitas questões pra mim, pra reflexões. E principalmente em relação à sociedade. Eu lembro que esse meu vizinho, ele me infernizava muito porque ele questionava comigo, porque que eu dançava axé. Eu falava "porque eu gosto, porque eu gosto". [E ele dizia:] "Não, você não acha que expõe o corpo da mulher, que banaliza o sexo?". Então, e aí eram vários questionamentos. E, quando eu vim pro espaço da biblioteca, as pessoas daqui também começaram a me lançar uma série de questionamentos pra eu refletir. E aí eu acho que até pela idade, pela curiosidade - eu fui querendo ler, querendo saber, querendo discutir, querendo formar a minha opinião, porque eu sempre percebia que a opinião das pessoas era diferente, que eu até concordava, mas eu queria saber dar minha opinião pelo conhecimento que eu tinha, não só por achar que é legal. Então, isso me fez me lançar mais à questão de ler.

Frida: O pessoal do Força Ativa já lia bastante e te incentiva demais, eles jogam um "gás" assim impressionante. É bem legal.

Depois dos primeiros contatos, para os consulentes que já freqüentavam a BCST há algum tempo, para além da difusão da concepção de leitura para obtenção de conhecimento, a mediação de leitura foi progressivamente consistindo da disseminação da idéia de leitura

para a emancipação do ser humano e transformação da realidade, do incentivo ao desenvolvimento de maior criticidade e do desestímulo às leituras feitas apenas por lazer/entretenimento, como os best-sellers. Houve grande incentivo ao desenvolvimento de leituras de História, Filosofia, Sociologia e de temas ligados à questão racial, chamados na BCST genericamente de "africanidade". Houve também ampla disseminação de conhecimentos de Ciências Humanas, assim como forte estímulo à escolarização:

Maria: Eles faziam muita piada porque eu pegava livros da Agatha Christie. E eu não entendia porque eu era... Esse meu vizinho, ele me presenteou com o livro $O$ assassinato no Expresso Oriente e eu amei. E aí, eles ficavam fazendo piada e eu não entendia... Porque eu pegava Agatha Christie e tal. No começo, eles não me deram livros. Eu pegava aquele que era do meu gosto. Mas eu lembro que eles sempre me pegavam pra ficar falando, falando, falando. E aí, eu lembro que depois eles começaram a 
me orientar: "Ah, por que não ler outras coisas? Tem essa estante aqui". E aí, eles começaram a me indicar. Eu lembro que, no começo, eu li bastante coisa sobre questão racial. E aí, era uma das discussões que a gente fazia muito aqui, né, da questão do padrão de beleza, auto-estima... E aí, eles, sei lá, pelos temas que eu demonstrava mais interesse...

Laís: Aí, comecei a ler livros sobre conhecimentos gerais [na BCST] e assim eu comecei a ler mais. Aí, eu tive uma fase de ler sobre quilombola, Fazenda e Senzala eu li um pouquinho para ter conhecimento mais da minha história. [Quem me incentivou a ler esses livros] foi o pessoal daqui. [...] Foi, foi o Wilson que me influenciou nessa parte e eu também não lia porque não tinha conhecimento sobre a raça negra, libertação, minha descendência, como se deu tudo isso. Até hoje ele fala: "Como você vê a liberdade? Como é a imagem do negro daquela época e da época de hoje? Mudou muito". E então, eu comecei a ler e descobri que quilombo não era só no Rio de Janeiro, não era só quilombo do Zumbi, eram vários quilombos e a gente não sabia. Teve uma luta muito grande em várias regiões que foram travadas, [que a história] não conta. E por isso comecei a ler para entender um pouco mais. Os professores tentam explicar, mas na minha sala não tinha muitos negros, eram pouquinhos. E a gente tinha aquele interesse de saber sua raiz e na escola não tem esse costume de falar sobre a raiz da família mesmo,né, a árvore genealógica. E aí, eu comecei a me interessar mais e ele dando esses livros, eu disse: "Nossa, agora estou compreendendo um pouco mais. Tirar essa idéia de que negro não gostava de livro, né. Não tenho mais essa idéia. Eu me pergunto: "Por que dizer que negro é orgulhoso?". E aí, comecei a mudar minha postura e de saber como foi a formação daquela população e ver como hoje mudou mais e tem escritores negros também. Aí, eu comecei a fazer pré-vestibular e aí eu comecei a ter mais conhecimento da minha Igreja. Aí, eu comecei a olhar com outros olhos a minha religião, a minha doutrina, que antigamente ela foi muito perversa, mas hoje ela deixou certos medos, mas dizer que a doutrina dela mudou completamente, não mudou. Mas aí comecei a ter esse olhar crítico maior mesmo, quando eu comecei a fazer esse exame, ainda mais freqüentando uma biblioteca que você conversa com vários tipos de gente, pega livros diferentes que fala de vários fatos da vida real ou não.

Laís: Hoje eu tenho assim: como eu queria estudar Psicologia, [se eu tivesse todo o tempo livre para ler] eu iria pegar livros de Psicologia, um pouco de Filosofia, [os membros do Força Ativa] falaram que é bom porque a Filosofia abre um pouco mais a mente das pessoas na parte crítica e essa parte de aventuras, que mistura um pouco realidade e fictícia.

A mediação que se deu na BCST foi poderosa para transformar os sujeitos em leitores, realizando um trabalho que a escola e as outras bibliotecas ou não haviam feito ou haviam feito muito precariamente.

No grupo A, a BCST teve papel fundamental para a constituição de 6 leitores: AK47, Dandara, Frida, Laís, Maria e Marley. Excetuando-se raras visitas à biblioteca escolar e à biblioteca pública de Guaianases (apenas para a realização de trabalhos escolares), a BCST foi a primeira biblioteca que 5 desses 6 sujeitos de fato freqüentaram regularmente.

A mediação de leitura da BCST foi tão mais importante quanto menos práticas de leitura os sujeitos tivessem desenvolvido antes. Assim, ela foi menos significativa para André e Paula, que já tinham consolidado muitas práticas de leitura de livros antes de conheceram a BCST, do que para os outros 6 sujeitos:

Frida: [A minha reaproximação com a leitura] foi quando eu já estava me aproximando mais da biblioteca aqui [BCST].

Dandara: Na escola, a gente nunca ia muito pra sala de leitura. Então, eu não lia muitos livros, aí eu lia os livros que tinha em casa, né, aí... Assim, depois assim, que eu comecei a ler mesmo foi depois que, de adulto, né, e... Quando entrei pra biblioteca, aí, eu comecei a ler mais... 
[Eu procurei a biblioteca comunitária pela primeira vez quando] eu tinha uns vinte e três... vinte e dois... vinte e dois ou vinte e três, alguma coisa assim, mas... Foi o mais engraçado porque eu tava querendo ser voluntária em algum lugar, aí. Eu sabia que tinha uma biblioteca aqui, eu conhecia os meninos. Aí, eu vim e não foi porque eu quis ler ou alguma coisa assim... Eu não encontrava emprego. Achei que, como voluntária, seria mais fácil. Hoje, já penso diferente. Aí, eu entrei pra biblioteca e tô aqui até hoje, assim. Eu adquiri o gosto pela leitura.

No espaço da BCST, houve forte estímulo à escolarização e à leitura, difusão das concepções de leitura para obtenção de conhecimento e para emancipação do ser humano e transformação da realidade.

A mediação de leitura da BCST confundiu-se em muitos momentos com aquela do movimento social Força Ativa, já que 6 dos 8 sujeitos - AK47, Dandara, Frida, Laís, Maria e Marley - passaram a ter muito contato com os seus membros, tornando-se voluntários da BCST. Cinco deles (a exceção foi Laís) desenvolveram práticas de leitura também em função de seu engajamento em atividades do movimento não diretamente relacionadas à BCST. Esses 5 sujeitos se tornariam depois não apenas leitores, mas também integrantes do Força Ativa.

Os trechos abaixo mostram a importância que atuar como voluntários da BCST teve para a constituição dos 6 leitores. Tal atuação, para além de proporcionar maior acesso e o contato com o material impresso, aumentou a freqüência de interação com os mediadores de leitura que já pertenciam ao Força Ativa:

Dandara: Ah, acho que só as pessoas do grupo mesmo que me incentivaram a ler, e o contato com os livros é importante, né. Quando você não tem contato, é meio complicado, porque é um privilégio estar aqui dentro de uma biblioteca. Mas tem pessoas que não têm. Às vezes, não sabem nem que tem uma biblioteca comunitária, e a biblioteca pública fica um pouco longe daqui. Aí, não tem contato com os livros, aí, não tem como você gostar de alguma coisa se você não tem contato. Aí, só tem a televisão lá na sua cabeça. Aí que você não vai gostar mesmo de livro. Se você estiver sem fazer nada com um bom livro do seu lado, não tem nada na televisão, aí, você pega o livro e começa a ler. Aí, você vai adquirindo o gosto de ler.

$[\ldots]$

Quando você está diante de vários livros assim, aí, conforme você vai separando os livros, vai tomando contato com os livros, você vai vendo aqueles livros que te interessa, tem uns títulos legais, assim. No entanto, quando eu entrei na biblioteca, eu li muito livro de literatura infanto-juvenil. Nossa! Lia direto, na biblioteca não dava tempo de ler [por]que era muita pessoa entrando e saindo. Aí, eu começava a ler um pouquinho, aí, já levava pra casa e já lia. Até hoje eu sou assim. Tipo assim, se eu vejo um livro, tô mexendo em um livro aqui, aí vejo um livro e já quero ler já, aí vem outro, eu quero ler outro. Às vezes, era tanta coisa assim, tanto, tanto livro legal que eu queria ler, [que] no fim, não acabava, não conseguia ler nenhum. Eu começava com um, aí, depois já passava para o outro e não terminava o outro. Eu ficava assim, é uma sede de leitura, mas que parecia que travava assim, lia bastante, chegava até um pedaço, aí já queria ler outro livro que eu achava que era mais interessante. Aí, no fim eu achava outro e assim ia. [...]

Conforme você vai folheando, vai arrumando os livros, aí você vai encontrando aqueles que você não tinha visto, aqueles que estavam emprestados e você não viu. Aí é assim mais ou menos...

\footnotetext{
AK47: Aí, foi no período que montou a biblioteca e eu comecei a ser mediador de leitura na biblioteca. E aí, eu tive um contato maior com outras possibilidades de leitura, sendo mediador de leitura nessa biblioteca. Sempre tem [recomendações e discussões de leituras pelos membros do Força Ativa], desde que eu tive contato com o pessoal do Força Ativa e com o que eles faziam, o pessoal sempre falava da importância da leitura porque eles vinham desde o ano de 1995 aqui na Cidade Tiradentes fazendo essa discussão, né.
} 
[...]Primeiro, ele [o atendente voluntário da BCST] tem que conhecer o livro, coisa que eu não conhecia quando eu entrei na biblioteca. Para mim conhecer os livros, eu tive que ir folheando, ter contato com os livros... Então, é conhecer os livros, saber dialogar com as pessoas que vêm até a biblioteca. Também acho que é importante, também, estar tentando criar um vínculo maior com a comunidade. Então, eu ficava aqui de segunda à sexta-feira das dez à uma hora. Agora, eu não posso mais ficar todo esse tempo, mas pelo menos dois dias na semana eu estou aqui na biblioteca. Eu acho que esse trabalho na biblioteca do ano de 2001 até aqui foi o trabalho que mais me potencializou para muitas coisas. [...] Eu acho que me potencializou para tudo, tanto para o modo de me expressar, saber falar em público, saber organizar uma atividade, uma oficina, preparar uma sala, aprender a catalogar livro porque eu não sou atendente da biblioteca, não fiz Biblioteconomia, mas a gente fez uma formação aqui de como catalogar livro, como organizar um acervo, distinguir as áreas de conhecimento, ter mais disciplina quanto ao estudo, porque senão a gente não consegue entrar na universidade.

Dandara: Ah, eu acho que [quem me incentivou a ler foi] só o pessoal do grupo, assim, me incentivou bastante... [Eles] me indicavam livros pra ler... Livros bons... assim pra ler. Tinha o Wilson, ele me indicou vários livros, me emprestou alguns pra mim ler. Ele incentiva bastante... a leitura... algum assunto que estou interessada em saber, ele já me indicou um livro, assim. Aí, a maioria do grupo é assim: incentiva bastante.

Frida: Comecei a vir na biblioteca [comunitária] porque eu tinha uma amiga que já freqüentava a biblioteca e já conhecia algumas pessoas do Força Ativa. Ela não era do Força Ativa e nem eu. E como eu gosto muito de ler e eu achava muito legal. E eu sempre achei, depois que eu vim morar pra cá, depois que, assim... eu fui crescendo mais, eu queria contribuir, porque eu sei que era um lugar difícil de se viver, morar e tem todo aquele preconceito de morar em Cidade Tiradentes. E eu via que não era bem assim como as pessoas falavam. Então, eu queria fazer alguma coisa pelo bairro que eu moro, né. Então, quando eu encontrei a biblioteca e vi que era um caminho e como a biblioteca não é do poder público, que não era do Estado e nem do município e que era voluntário, uma coisa bem tranqüila, eu achei legal. Eu comecei a ser voluntária da biblioteca porque eu vi que era uma forma de contribuir e de me aproximar mais dos livros. E eu gostava muito de ler e eu vi que tinha muitos temas legais que eu queria ler. [...] Eu li a Santa Joana do Matadouro, eu li sobre Carlos Mariguela, que já vem numa outra linha, sobre... Deixa eu lembrar... Depois, quando eu comecei a me aproximar um pouco mais do Força Ativa, eu comecei a ler, tentar ler porque - mas eu não entendia muito bem - eu já queria ler sobre o Lênin, que é uma referência dentro do grupo. Marx, eu sei que era teórico, um filósofo. Então, era mais difícil e tinha que ficar mais pra frente. Então, ler sobre questão racial, sei lá, saber mais sobre Zumbi. Aqui na biblioteca é que eu vim aprender mais sobre Zumbi dos Palmares, quem era Dandara, a história da escravidão no Brasil... foi mais aqui na biblioteca. Na escola, não lembro de alguma coisa que tenha sido enfatizada da História do Brasil.

Os trechos a seguir ilustram a importância do engajamento em atividades do movimento social Força Ativa não diretamente relacionadas à BCST para a constituição dos leitores. Tais atividades mobilizaram o desejo de saber mais, favoreceram a inserção em outras modalidades de escolarização, abriram novas perspectivas de escolarização e de atuação profissional. Além disso, desenvolveram as competências leitoras dos sujeitos, propiciando-lhes o que a escola não havia ensinado ou o tinha feito precariamente (como usar o dicionário, fazer pesquisas, estabelecer comparações intertextuais, relacionar o texto à realidade vivida, analisá-lo, sintetizá-lo, criticá-lo etc):

AK47: Depois, eu comecei a fazer alguns cursos comunitários, cursos de cidadania e aí foram abrindo novas perspectivas. A gente vai conhecendo coisas novas e aí a necessidade de você buscar informação. Aí, você vai buscar nos livros. [...] Eu aprendi num grupo de estudo [do Força Ativa] de domínio de texto, mesmo que o texto você não entender nada, mas você aprender não só ler as palavras, mas abrir o dicionário, pesquisar, pegar outro livro que está falando a mesma coisa. É estudar de verdade, escrever sobre o texto, tentar fazer uma resenha sobre o texto, o que você entendeu sobre o texto, organizar as 
idéias, tentar relacionar com o que a gente vive. Isso eu chamo de disciplina: não só ler o texto, mas você decompor.

Maria: Como aqui é de um movimento social, em paralelo com as minhas leituras, eu comecei a ter algumas atuações aqui no bairro. Então, eu fui ser agente de prevenção, passei a fazer alguns trabalhos que me trouxeram muito, me enriqueceram muito. E tem a questão da leitura, né, do conhecimento em si e tem a questão da experiência de vida. E a minha atuação na comunidade, em lidar com as pessoas, de estar envolvida e discutindo, estimulando a mudança de comportamento das pessoas, me trouxe um enriquecimento muito grande, uma experiência de vida muito grande, então... nessa biblioteca [é que me formei leitora] porque, das que eu tenho contato, nenhuma outra fez um diferencial.

No espaço da BCST, ocorreu também, por parte de alguns mediadores, um forte desestímulo à leitura de obras clássicas de literatura brasileira de modo geral, considerada burguesa, e de obras de autores tidos por eles como racistas ou traidores das causas negras, como, por exemplo, Machado de Assis e Mário de Andrade. Por outro lado, alguns mediadores incentivaram a leitura de autores que reputaram ter estado alinhados com a concepção de leitura para emancipação do ser humano e transformação da realidade, dentre os quais estão Lima Barreto e Cruz e Souza:

Frida: Mas esse gosto de ler, por exemplo, o Lima Barreto é incentivo do pessoal do grupo aqui do Força Ativa. Então, algumas literaturas eu só aprendi a gostar porque eu vi que é... do jeito que o pessoal trouxe, para mim, é diferente. Por exemplo, quando trouxeram Lima Barreto, Cruz e Souza, pelas características deles, de serem negros, de escrever... Da forma que eles escreveram como eles eram tratados naquela sociedade, que eles viviam como negros, né. Então, eu acho legal assim e eu até aprendi a gostar. Mas não é uma coisa que eu quero ficar lendo.

Assim, se de um lado a BCST desencorajou a leitura de certos autores, mediou a leitura das obras de outro, o que foi absolutamente extraordinário, pois, se não o fizesse, alguns sujeitos provavelmente não teriam lido nenhuma obra de literatura depois de deixar a escola básica. Interessante ressaltar que, na mediação dos livros dos autores mais legitimados pela BCST, novamente fez-se o trabalho que a escola deixou de fazer ou fez precariamente: geração de interesse mediando a temática da obra e apresentando a conexão entre ela e a realidade do sujeito, estímulo ao uso de dicionário e de referências intertextuais para potencializar a compreensão, localização histórica da obra, incentivo à interlocução sobre as impressões de leitura etc.

A mediação de leitura que se deu na BCST foi poderosíssima para transformar nãoleitores em leitores, alguns dos quais chegam a fazer leituras de obras de Filosofia, História, Sociologia etc., de complexidade extraordinária. Os sujeitos que não o fazem autonomamente participam dos debates, sanam dúvidas com os amigos e conseguem uma compreensão que os satisfaz e/ou os instiga a ler ainda mais. Nessa dinâmica, a leitura literária é sobrepujada pelas leituras que se faz para a emancipação do ser humano e para a transformação da realidade. 
Assim, é possível dizer que a mediação de leitura na BCST transforma não-leitores em leitores, mas não necessariamente não-leitores em leitores literários.

Em síntese, de acordo com os relatos coletados, o sucesso da BCST para a formação leitora de 6 sujeitos do grupo A reside na qualidade da mediação de leitura que ela realiza, caracterizada por aspectos de caráter afetivo e cognitivo: receptividade ao consulente que nela entra pela primeira vez, liberdade de manusear o acervo, disseminação de conhecimentos, demonstração de interesse pelas leituras feitas por ele e esclarecimento de eventuais dúvidas, estímulo à leitura, indicação de obras, estabelecimento de relações com a realidade, provocações à reflexão e difusão de concepções de leitura que não estão estritamente vinculadas à escolarização - a leitura para obtenção de conhecimento e a leitura para emancipação do ser humano e transformação da realidade - e, para alguns, a efetiva integração no movimento social. E o que nos parece fundamental é que tal mediação de leitura é realizada por alguém que é ele próprio modelo de leitor, alguém que desperta desejo de imitação, e que é, ao mesmo tempo, alguém muito próximo do leitor: é morador do mesmo bairro, é jovem e pertence à mesma camada social. Parece dar-se, assim, um processo de identificação com o que há de semelhante nesse mediador e de busca do que é diverso nele: os hábitos de leitura, o conhecimento, a capacidade de reflexão e debate etc.

\subsubsection{A biblioteca comunitária e o grupo B (os leitores de literatura)}

Para os sujeitos do grupo B, a biblioteca comunitária teve muito menos relevância para sua constituição leitora do que para aqueles do grupo A. De fato, o contato de 4 dos 5 sujeitos com a BCST deu-se depois que eles já tinham desenvolvido muitas práticas de leitura, inclusive de livros e dos clássicos da literatura. O quinto sujeito - Zapata -, por sua vez, esteve presente durante a própria gênese da BCST, tendo sido um de seus mentores. Naturalmente, antes do estabelecimento da BCST, ele também já era leitor:

Malik: Minha relação com o Força Ativa é bastante peculiar. Quando eu conheci o Força Ativa no ano de 2002, eu conheci, mas não vim para cá [BCST] imediatamente. Vinha aqui, olhava a política e, como eu estava me preparando para o vestibular e estava determinado a ser aprovado, então, eu não freqüentava aqui muito. [...] Eu ingressei no Força Ativa no ano de 2004. No ano de 2004 mesmo, eu fui embora. Então, eu vinha para fazer trabalho muito esporadicamente. Então, a leitura vinha anterior dessa história que eu te contei. Mas, como eu fui para a universidade, eu não tinha como estar aqui. Estudar fora de São Paulo e pouco contato, eu não conheço o acervo da biblioteca, eu desconheço o acervo.

Álvares: Essa biblioteca [a BCST], eu já conhecia há muitos anos. Só que aí eu não queria fazer parte do movimento [Força Ativa] porque, até então, eu não estava certo do que eu acreditava. Eu não tinha contato, não conhecia direito. Depois que eu tive um acesso e fui conhecer pelo grupo de estudos, de 
leitura das coisas que eu acreditava e tal, e aí eu comecei a perceber que essas pessoas eram pessoas diferenciadas, pessoas que tem toda um... um, pessoas que tem aí fora, contradições dentro do capitalismo e dentro da chamada dita periferia.

[...]

Eu vim trabalhar aqui no ano passado, sabia que existia, mas eu cheguei... Tinha umas bibliotecas comunitárias por aqui, mas eu ia nas bibliotecas das regiões centrais. Eu tinha descrédito quanto à capacidade da comunidade ter uma literatura boa porque a maioria das bibliotecas comunitárias, essa aqui é a maior exceção, porque a maioria delas são livros paradidáticos, livros repetidos e muitas literaturas repetidas, às vezes, tem um acervo grande, mas a literatura não é tão boa. Então, quer dizer que eu tinha um descrédito...

Ao descrever o contato com a biblioteca comunitária, 1 sujeito aludiu à simpatia e à facilidade de interlocução com a atendente, enquanto outro enfatizou o fato de ficar à vontade para manusear as obras:

Beatriz: Ah, eu sempre fui leitora antes, mas a mocinha que atende... que eu não sei o nome dela... Ela sempre pergunta: “Aí, que livro você quer ler?". Aí, ela: “Ah! Esse eu já li. É interessante. Lê. Vocês vão gostar". Ela foi extremamente simpática. Eu acho. Porque convida mais as pessoas para ler, uma pessoa simpática. Você entra na biblioteca e uma pessoa simpática já fala com você, pergunta que livro que você quer ler. Fala se ela gostou, se ela não gostou. Isso é convidativo. Mas, se você entra na biblioteca, a pessoa tá séria, e nem fala com você, você fica perdida na biblioteca porque são várias opções para ler. Por isso que eu acho que é importante.

Taiko: É muito raro eu trocar idéias sobre livros com eles [os atendentes das bibliotecas comunitárias], sabe. Mas, quando era na época da Dandara, quando a Dandara estava, eu tinha mais essa liberdade de conversar com ela, [risos] não sei se é porque mulher... com mulher, a gente tem mais liberdade. Aí, ela deixava eu à vontade, eu ia, procurava os livros, aí, eu lia o trechinho que resumia a história do livro, lia e, se eu gostasse, eu levava para casa.

A mediação de leitura na BCST consistiu de recomendação de obras, de interlocução sobre leituras nos casos de Beatriz e Taiko e não foi determinante para sua constituição leitora. Para Álvares, Malik e Zapata, a mediação da BCST e de seus atendentes confundiu-se com aquela de seus pares do Força Ativa e, repetimos, não foi determinante para sua constituição como leitores. Podemos dizer que dois deles - Álvares e Malik - contribuíram mais para a BCST e para o Força Ativa do que foram formados por eles. De fato, dado seu grau de escolarização e de práticas de leitura, quando Álvares e Malik entram em contato com a BCST, não o fazem na qualidade de alguém que apenas aprende e assimila os conhecimentos mediados naquele espaço, mas sim como alguém que vai, de igual para igual, ensinar e aprender, ou seja, compartilhar. Zapata, por sua vez, participou da gênese do Força Ativa e foi mentor da BCST. Esteve ele próprio também sempre na condição de par dos outros líderes do Força Ativa. Nesse sentido, é possível dizer que a mediação de leitura que se dá entre Álvares, Malik e Zapata e a BCST e o Força Ativa consistiu do compartilhamento das concepções de leitura para obtenção de conhecimento e de leitura para a emancipação do ser humano e transformação da realidade e o desestímulo às leituras feitas apenas por lazer/entretenimento, como os best-sellers, do incentivo ao desenvolvimento de leituras de 
História, Filosofia, Sociologia e de temas ligados à questão racial, chamados na BCST genericamente de "africanidade". Incluiu ainda o compartilhamento dos conhecimentos que cada um dos membros do Força Ativa adquiriu em seus vários cursos de graduação, em especial, em Ciências Humanas, a condução de grupos de estudos, onde se deu interlocução muito refinada sobre livros e leituras. Como representantes da cultura tipicamente letrada, Álvares e Malik, ao passarem a freqüentar a BCST, já são pares dos líderes do Força Ativa e rapidamente tornam-se eles próprios líderes também ${ }^{95}$.

Embora já fossem leitores antes de freqüentar a BCST, para 3 sujeitos - Álvares, Malik e Zapata - a biblioteca foi importante no sentido de favorecer o livre acesso a um acervo de boa qualidade e o contato com seus pares leitores:

\begin{abstract}
Álvares: E aí, eu comecei a ver que o grupo te dá mais força e te dá mais acesso à leitura e também te dá mais contato com os livros. Eu fiquei em muito contato com os livros na catalogação do ano passado - pegar livro, catalogar, tocar, pegar, ter contato físico. Eu tenho esse negócio também do contato físico, eu acho interessante. [...] Eu me sentia ilhado, eu me sinto ilhado e cada pessoa, principalmente aqui no Força Ativa, são ilhas que se encontram. E é interessante porque é um espaço que a gente pode falar aquilo que a gente quer porque não é um mundo comum, não é um mundo cotidiano. No cotidiano, no mundo do senso comum, não dá pra falar certas coisas porque a gente é tachado como crítico. Vai alugar um filme, eles acham o filme chato. É um filme que ninguém quer assistir. O contato com um grupo de movimento social ajuda você a dar sentido pra sua existência, e querer continuar existindo [...] e descobrir que você faz parte de um povo igual a esse, que faz parte do movimento do preto, do afrodescendente e saber que é uma luta de libertação, que é uma luta que não é só racial, uma luta para libertar todos os pobres e que é uma luta. E que a literatura tem disso, de começo, desenvolvimento e uma conclusão, né.
\end{abstract}

A freqüência da mediação com os atendentes da biblioteca comunitária parece ter sido semanal para 2 sujeitos - Beatriz e Taiko - e foi quase diária para os outros - Álvares, Malik e Zapata -, que se envolveram em atividades diversas da BCST e do Força Ativa.

\title{
4.7.4 As bibliotecas escolar, pública e comunitária: comparando os grupos A e B
}

De modo geral, o grupo B de leitores visitou por períodos mais longos e com maior frequiência as bibliotecas escolar e pública que os sujeitos do grupo A, conforme a tabela abaixo tenta evidenciar:

\footnotetext{
${ }^{95}$ Em encontro casual em abril de 2009, alguns membros do Força Ativa desaconselharam-me a empregar o termo líder, já que o grupo se considera um coletivo, ou seja, não hierarquiza seus integrantes. No entanto, após assistir a algumas atividades do grupo, pareceu-me que emerge naturalmente nas relações uma certa liderança dos membros mais antigos, mais informados, politizados, escolarizados, em especial, em reuniões e debates. Daí minha opção, por falta de termo melhor, em manter a palavra líder.
} 
Grupo A (leitores)

\begin{tabular}{|c|c|c|c|c|c|c|c|c|c|c|c|c|}
\hline & \multicolumn{4}{|c|}{$\begin{array}{l}1^{o} . \text { segmento do Ensino } \\
\text { Fundamental }\end{array}$} & \multicolumn{4}{|c|}{$\begin{array}{c}2^{o} . \text { segmento do Ensino } \\
\text { Fundamental }\end{array}$} & \multicolumn{3}{|c|}{ Ensino Médio } & \multirow[t]{2}{*}{$\begin{array}{l}\text { Para além } \\
\text { da escola } \\
\text { básica }\end{array}$} \\
\hline & $1^{\mathrm{a}}$. & $2^{\mathrm{a}}$ & $3^{\mathrm{a}}$. & $4^{\mathrm{a}}$ & $5^{\mathrm{a}}$ & $6^{\mathrm{a}}$ & $7^{\mathrm{a}}$ & $8^{\mathrm{a}}$ & $1^{\circ}$. & $2^{\circ}$ & $3^{\circ}$. & \\
\hline AK47 & & & & & & $\mathrm{BE}$ & & & & & & BCST \\
\hline André & & & & & \multicolumn{7}{|c|}{ BP raramente } & \\
\hline Dandara & & & & & \multicolumn{7}{|c|}{$\begin{array}{l}\text { BE muito raramente } \\
\text { BP uma única vez }\end{array}$} & BCST \\
\hline Frida & $\mathrm{BE}$ & $\mathrm{BE}$ & & & \multicolumn{7}{|c|}{ BP raramente } & BCST \\
\hline Laís & & & & & \multicolumn{6}{|c|}{ BP raramente } & BCST & BCST \\
\hline Maria & & & & & \multicolumn{4}{|c|}{$\mathrm{BP}$ raramente } & $\mathrm{BE}$ & $\begin{array}{l}\text { BE } \\
\text { BCST }\end{array}$ & $\begin{array}{l}\text { BE } \\
\text { BCST }\end{array}$ & BCST \\
\hline Marley & & & & & \multicolumn{7}{|c|}{ BP raramente } & BCST \\
\hline Paula & BP & BP & $\mathrm{BP}$ & $\mathrm{BP}$ & $\mathrm{BE}$ & $\mathrm{BE}$ & $\mathrm{BE}$ & $\mathrm{BE}$ & $\mathrm{BE}$ & $\mathrm{BE}$ & BCST & \\
\hline
\end{tabular}

Grupo B (leitores de literatura)

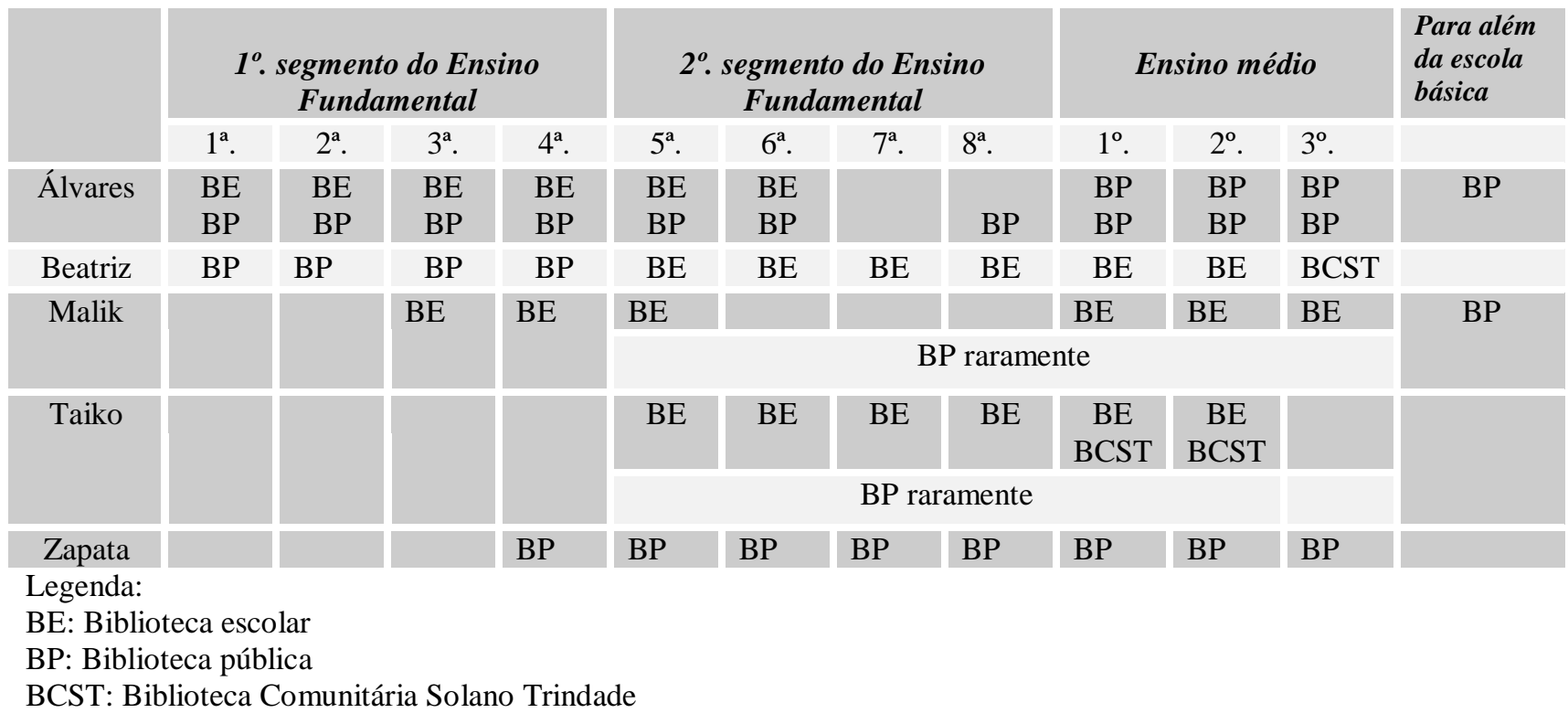

Os sujeitos do grupo B tinham práticas de leitura de livros consolidadas quando conheceram a BCST. Já para os sujeitos do grupo A, à exceção de Paula e André, a BCST foi estruturante de suas práticas de leitura. Tal caráter estruturante teve duas conseqüências. A primeira delas - extraordinariamente louvável - é que a BCST formou leitores de livros, dentre os quais obras bastante complexas, pessoas que, a julgar pelas condições de classe a elas impostas e pela estarrecedora omissão da escola, não se tornariam leitores. A segunda delas é que essas mesmas pessoas foram desestimuladas a realizar leituras de entretenimento e de literatura brasileira em função desta ser considerada burguesa e em função da urgência de 
fazer leituras que buscassem uma visão alternativa da realidade e um projeto de transformação social, principalmente de Ciências Sociais.

Mas leitores do grupo A já tenderiam a não fazer as leituras de literatura brasileira por problemas de falta de compreensão da linguagem e temática. Como explicar, então, que se proponham a ler obras de Filosofia e Política, às vezes, bastante herméticas? Eles parecem fazê-lo porque o pertencimento ao Força Ativa pressupõe esse tipo de leitura e porque os líderes do Força Ativa, que são leitores mais experientes, fazem uma intensa mediação dessas obras no cotidiano e, de modo mais formal, em grupos de estudo periódicos.

Assim, os sujeitos do grupo A, que não liam literatura brasileira, continuam a não fazê-lo independentemente de terem conhecido a BCST ou de terem se integrado ao Força Ativa. E os sujeitos do grupo B, que liam literatura brasileira, - Álvares, Malik e Zapata - e integram o Força Ativa continuam a fazê-lo independentemente de sua atuação no movimento. Mais do que isso, tornam-se eles próprios mediadores refinados nas reuniões e grupos de estudo do próprio Força Ativa. É nesse sentido que dizemos que, mais do que ser formados pela BCST, eles ajudam a conduzir a BCST. As outras 2 pesquisadas do grupo B Beatriz e Taiko - que tiveram pouco contato com os mediadores da BCST e não se integraram ao Força Ativa, continuam a fazer leituras de entretenimento que incluem a literatura brasileira.

Retomando a distinção dos tipos de leitura - funcional, de entretenimento e literária (SOARES, no prelo) - interessante pontuar que, no contexto de intensa mediação e sociabilidade em torno dos textos de Ciências Humanas entre os membros do Força Ativa, o modo de ler um texto de Filosofia pode ser, além de funcional, de entretenimento, a despeito do caráter hermético do texto para alguns.

\subsection{A mediação de leitura pelo grupo de pares}

Neste tópico, objetivo analisar qual foi a mediação de leitura exercida pelos grupos de pares. Para facilitar a visualização dos dados coletados sobre tais grupos, oferecemos nas páginas a seguir quadros sinópticos com as informações fornecidas pelos sujeitos dos grupos A e B.

Embora tais quadros contenham informações sobre todos os amigos e colegas dos sujeitos, o foco de minha análise recairá sobre os vizinhos, amigos da rua e do grupo de estilo e namorados, ou seja, não nos deteremos nas pessoas que o sujeito conheceu no âmbito da 
escola e da BCST ou do Força Ativa, em especial, após a inauguração da biblioteca comunitária. O motivo de tal decisão reside no fato de que a atuação dos mediadores na escola e na BCST e no Força Ativa já foi alvo de análise quando me dediquei às questões da escola e da biblioteca comunitária.

Ora, se assim é, por que manter todos esses colegas e amigos nos quadros? Para a construção, ao final da análise, do argumento sobre as diferenças de idade e de maturidade leitora entre os colegas e amigos com quem os sujeitos dos grupos A e B tiveram oportunidade de se relacionar.

De qualquer modo, para reduzir o tempo necessário à leitura dos quadros, destacamos em amarelo as informações que são novas. 


\section{MEDIAÇÃO DE LEITURA PELOS PARES - GRUPO A (Leitores)}

\begin{tabular}{|c|c|c|c|}
\hline Sujeito & Quem e quando? & Qual foi a mediação e como ela se deu? & Freqüiência \\
\hline \multirow[t]{2}{*}{ AK47 } & $\begin{array}{l}\text { Grupo de estilo (rap) a partir dos } \\
20 \text { anos. }\end{array}$ & Incentivo à reflexão e à leitura. & Constante \\
\hline & $\begin{array}{l}\text { Colegas na BCST e no Força } \\
\text { Ativa a partir dos } 17 \text { anos }\end{array}$ & $\begin{array}{l}\text { Por meio do FA ou BCST faz cursos que suscitam necessidade de buscar mais conhecimento. } \\
\text { Incentivo à reflexão e à leitura. } \\
\text { Introdução a novo canal de distribuição de livros: o sebo. }\end{array}$ & Diária \\
\hline \multirow[t]{2}{*}{ ANDRÉ } & $\begin{array}{l}\text { Colegas na escola a partir dos } 13 \\
\text { anos aproximadamente }\end{array}$ & $\begin{array}{l}\text { Encarregado de fazer os trabalhos escolares na biblioteca. } \\
\text { A leitura lhe conferia respeito, status de inteligência. }\end{array}$ & Diária \\
\hline & $\begin{array}{l}\text { Colegas na escola e no trabalho } \\
\text { a partir dos } 14 \text { anos aproxim. }\end{array}$ & Interlocução sobre leituras esotéricas e empréstimos de livros, apostilas, gibis & Diária \\
\hline DANDARA & $\begin{array}{l}\text { Colegas na BCST e no Força } \\
\text { Ativa }\end{array}$ & $\begin{array}{l}\text { Incentivo à leitura e à escolarização. } \\
\text { Desenvolvimento de "visão crítica": "você tem que ler algum livro que te acrescente alguma coisa" } \\
\text { Recomendação de livros (reservas quanto aos clássicos da literatura brasileira) }\end{array}$ & Diária \\
\hline \multirow[t]{3}{*}{ FRIDA } & Colega de escola & Interlocução sobre leituras e empréstimos de livros, gibis e revistas. & Diária \\
\hline & $\begin{array}{l}\text { Grupo de estilo (rap) } \\
\text { a partir dos } 15 \text { anos }\end{array}$ & Incentivo à leitura, à reflexão e à escrita. & Diária \\
\hline & $\begin{array}{l}\text { Colegas na BCST e no Força } \\
\text { Ativa }\end{array}$ & $\begin{array}{l}\text { Incentivo à leitura e à escolarização. } \\
\text { Emergência de necessidade de novas leituras devido às ocupações que os membros do FA passam a ter } \\
\text { Recomendação de leituras pelo Força Ativa } \\
\text { Desenvolvimento de "visão crítica" pela BCST e pelo Força Ativa (ou seja, influência sobre o modo de } \\
\text { ler e sobre o que ler) } \\
\text { Influência do Força Ativa como um todo na escolha da graduação } \\
\text { Introdução a novo canal de distribuição de livros: o sebo }\end{array}$ & Quase diária. \\
\hline \multirow[t]{2}{*}{ LAÍS } & Vizinhos & Interlocução com vizinho leitor mais experiente e incentivo à escolarização por outro vizinho leitor & $\begin{array}{l}\text { Semanal no } \\
\text { mínimo. }\end{array}$ \\
\hline & Colegas na escola & $\begin{array}{l}\text { Interlocução sobre leituras e incentivo mútuo à leitura } \\
\text { Elogios à sua capacidade de memorização de texto }\end{array}$ & Diária. \\
\hline
\end{tabular}




\section{MARIA Vizinhos}

Colegas do Força Ativa

MARLEY

Vizinho (aos 12 anos)

Grupo de estilo (rap) e militância (Movimento Negro) a partir dos

12 anos

Colegas do Força Ativa a partir dos 17 anos

\section{PAULA}

Amigos da escola $\left(2^{\circ}\right.$. segmento
Interlocução com vizinhos leitores mais experientes e incentivo à escolarização.

Desenvolvimento de "visão crítica", influência sobre o modo de ler e sobre o que ler

Incentivo à escolarização.

Incentivo à leitura e emergência de novas necessidades de leitura devido às ocupações que os membros

do FA passam a ter.

Recomendação de obras.

Empréstimos, leitura compartilhada de gibis e interlocução sobre eles.

Incentivo à leitura, reflexão e escrita.

Interlocução sobre leituras.

Estímulo à escolarização e à freqüência a bibliotecas.

\section{Incentivo à leitura, reflexão e escrita.}

Interlocução sobre leituras.

Estímulo à escolarização e à frequiência a bibliotecas.
Quase diária.

Quase diária. Diária

Mais que

semanal

\section{Quase}

diária

do EF ao $2^{\circ}$. ano do EM)

Interlocução sobre leituras e incentivo mútuo à leitura.

Sociabilidade girando em torno do livro 


\section{MEDIAÇÃO DE LEITURA PELOS PARES - GRUPO B (Leitores de literatura)}

\begin{tabular}{|c|c|}
\hline Sujeito & Quem e quando? \\
\hline \multirow[t]{4}{*}{ ÁLVARES } & Colegas na escola (EF e EM) \\
\hline & Amigo (dos 18 aos 28 anos) \\
\hline & Colega na universidade \\
\hline & $\begin{array}{l}\text { Amigos na BCST a partir dos } \\
27 \text { anos }\end{array}$ \\
\hline \multirow[t]{2}{*}{ BEATRIZ } & $\begin{array}{l}\text { Colegas na escola (EFII até } 1^{\circ} \text {. } \\
\text { ano do EM) }\end{array}$ \\
\hline & $\begin{array}{l}\text { Namorado ( } 3 \text { anos, aproxima- } \\
\text { damente dos } 17 \text { aos 19) }\end{array}$ \\
\hline \multirow[t]{5}{*}{ MALIK } & $\begin{array}{l}\text { Amigo na escola }\left(4^{\mathrm{a}} . \text { e } 5^{\mathrm{a}} \text {. }\right. \\
\text { séries })\end{array}$ \\
\hline & Colegas na escola (EF) \\
\hline & Melhor amigo na escola (EM) \\
\hline & Namorada a partir dos 17 anos \\
\hline & $\begin{array}{l}\text { Amigos nos grupos de estilo } \\
\text { (rock e rap) dos } 17 \text { aos } 22 \text { anos }\end{array}$ \\
\hline \multicolumn{2}{|l|}{ TAIKO } \\
\hline \multirow[t]{3}{*}{ ZAPATA } & $\begin{array}{l}\text { O fenômeno do rap de modo } \\
\text { geral }\end{array}$ \\
\hline & $\begin{array}{l}\text { Amigo no grupo de estilo ( } \mathrm{rap} \text { ) } \\
\text { a partir dos } 16 \text { anos }\end{array}$ \\
\hline & Colegas do Força Ativa \\
\hline
\end{tabular}

\section{Qual foi a mediação e como ela se deu?}

Desencorajamento ao caráter de bom aluno e leitor

Hostilidade com violência física e verbal (bullying)

Relação mestre-discípulo e ocupação profissional muito letrada.

Interlocução com leitor mais experiente e muito mais escolarizado.

Discussão e debate sobre conteúdo da graduação.

Apoio dos pares e maior acesso a livros.

Interlocução sobre leituras, incentivo à leitura, intercâmbio de material impresso

Interlocução com namorado, incentivo mútuo à leitura, intercâmbio de material impresso.

Modelo de leitor dos clássicos da literatura.

Interlocução sobre gibis e empréstimos.

Espécie de mediação negativa, o que suscita desejo de ter excelente aproveitamento.

Hostilidade com violência verbal (bullying): vítima de preconceito racial e social.

Interlocução com leitor mais experiente, crítico e politizado. Estímulo à leitura e reflexão. Exposição

a tipos de música considerados mais legítimos. Introdução ao rap. Incentivo à análise das letras.

Incentivo à escolarização (ensino superior na universidade pública).

Introdução ao grupo de estilo.

Interlocução sobre leituras. Estímulo à leitura.

Envolvimento em movimento social.

Mediação aparentemente não significativa entre os colegas da mesma escola

Busca interlocutores mais escolarizados e experientes em OME, palestras e cursos promovidos pela

EDUCAFRO e instituições semelhantes.

Incentivo à leitura e à escolarização.

Disseminação de conhecimentos, recomendações de obras e interlocução sobre as leituras com leitores mais experientes e mais escolarizados. Politização.

Influência na escolha da graduação em Letras.
Diária

Freqüiência

Diária

Quase diária.

Diária

Semanal

Ignorada

Diária

Constante

Diária

Mais que

semanal

Quase diária

Diária

Mais que

semanal 


\subsubsection{A mediação de leitura pelo grupo de pares - Grupo A (os leitores)}

A maior parte dos sujeitos do grupo A conviveu com algum vizinho ou amigo que era leitor, com espectro de mediação de leitura bastante variado. Para a constituição de 3 deles, o grupo de estilo rap assumiu grande relevância.

No grupo A, 4 dos 8 leitores - André, Paula, Laís e Frida - citaram colegas na escola, com os quais houve incentivo mútuo à leitura e interlocução sobre as leituras realizadas. Para a maior parte dos sujeitos, tal interlocução esteve vinculada também a empréstimos de material impresso. O contato dos 4 sujeitos com seus colegas leitores parece ter sido bastante freqüente e, em muitos casos, quase diário.

Três dos 8 sujeitos do grupo A - Laís, Maria e Marley - fizeram referência a vizinhos leitores. O espectro de influência exercida pelos vizinhos foi bastante amplo, variando em função da idade que os sujeitos tinham quando ela se deu, do grau de escolarização do mediador e de seus interesses. A influência foi de uma sociabilidade em torno dos gibis com uma criança da mesma idade - no caso de Marley -, à disseminação de conhecimentos e incentivo à leitura, à reflexão e ao debate por um modelo de leitor, alguém mais experiente, no caso de Laís e Maria, ambas já na adolescência. Maria beneficiou-se ainda de: incentivo à escolarização e seleção e acesso a livros de modo gradativo - do mais fácil para o difícil; difusão das concepções de leitura por prazer/lazer, leitura para obtenção de conhecimento e leitura para a emancipação do ser humano e transformação da realidade. O contato com os vizinhos ocorreu com relativa freqüência - em alguns casos, quase diariamente - e durante cerca de 2 a 3 anos.

Marley: É. A gente fazia umas disputas, quem chegava primeiro, quantos gibis [ganhava]. No futebol, quem ganhar, tá valendo gibi. Então, tipo bolinha de gude. Às vezes, a gente acabava emprestando, mas tem sempre um alguém que tem mais condições financeiras. Então, ele acaba comprando todos os gibis que tinha no mês assim e... "Ah! Comprei as novas". E a gente lia junto e tal. [...] A casa dele também era um clube da cidade quase, lá. [...] Então, quando ele mudou, a rua ficou um pouco mais difícil, porque era umas coisas que ocupava nossa mente. Porque depois, além do gibi, tinha a questão do futebol de botão, que era uma febre. Futebol de botão, nossa! Fazia diversos campeonatos na rua, campeonato da escola, do bairro e eu sempre bem colocado... [Eu] tinha em torno de doze, treze anos [quando convivi com o Roberto] lá na Vila Nova Cachoeirinha. [...] Mas eu acho que o Roberto foi um facilitador. [...] Ele botava a gente para dentro, ele afrontava a família dele. Ele falava: "São meus amigos". E a gente se sentia - como que eu posso dizer? - acolhido. Ele passava que: "Ah, eu gosto deles independente se estão de chinelo, se o cabelo é assim ou assado. São meus amigos".

Laís: E aí, conforme eu comecei a ler outros livros, eu fui começando a ver e me falaram que no livro que se lê, cinqüenta por cento é verdade e cinqüenta por cento é mentira. E quando me falaram isso eu disse: "Por quê?". E aí, ele me respondeu: "Só o autor vai poder dizer se foi verdade ou não foi. E quem escreve sempre vai aumentar a história ou os fatos. Você nunca pode falar que aquilo é totalmente verídico, que é verdadeiro mesmo". Aí, começou mesmo uma influência de pegar livro... [Quem me falou isso] foi um vizinho meu, quando você fica perto de uma pessoa que é muito inteligente parece 
que influencia a gente mais ainda, né, porque a pessoa inteligente tem a mente muito mais aberta, entende mais as coisas e eu nem sei como expor isso.

[...]

Esse é meu vizinho e ele tem essa mania de religião e gosta de ler. E minha prima também: ela gosta muito de discutir religião. E minha prima começou a praticar essa igreja dos mórmons. [...] E nisso esse meu vizinho ele tinha mania de investigar sobre certas religiões e aí ele começou a pesquisar essa igreja. [...] E aí, ele foi descobrindo várias coisas dessa igreja, que antigamente tinha bigamia, onde o homem podia ficar com muitas mulheres naquela época, e desvirtuou toda a história da Bíblia, que Maria teve um filho, não do Espírito Santo, mas de um homem e contou tudo totalmente diferente e a gente falou: "Nossa, agora começou "a tirar" mesmo, né". [...] E é como ele fala: "Todo mundo fala mal da Igreja Católica e o que fizeram de errado. E essa igreja? Por que escondeu, né?”. [...] Aí, ele chegou e pegou o livro de uma "ex" dessa religião dos mórmons e ela contou tudo que ocorreu. E no livro estava escrito que nem tudo que estava escrito num livro é a verdade. Aí, eu fiquei prestando atenção e vi que agora sim é que estava caindo a ficha, porque a gente lê só uma parte e geralmente aquela parte é maravilhosa. E esse vizinho que pesquisou e que chamou a atenção da gente e foi explicando para a gente muito bem. E chamou o pessoal dos mórmons que dava aula para a gente e eles passaram o lado deles, mas teve hora que eles afirmaram que isso foi real, que foi assim que tudo aconteceu. [...] E aí, fez uma mistura e foi aí que eu comecei a me interessar mesmo.

Maria: Eu decidi ir pra lá porque, nesse período, esses vizinhos... eles vão fazer muito parte da minha história, esses que são donos da banca de jornal... eles já estudavam fora. E eles sempre faziam alguns comentários em relação à diferença das escolas. E já quando eu estava na oitava série, eles chegavam a perguntar pra mim se eu ia fazer faculdade, alguma outra coisa e era um assunto pra mim meio disperso. Mas eu comecei, até pelo meu histórico de vida, comecei a pensar um pouco mais sobre como seria meu futuro. E aí eu, na busca de... sei lá, uma escola um pouco melhor, e já pensando no vestibular, é que eu decidi me mudar de escola. Então, eu sofri um pouco de influência dos meus vizinhos que já estudavam, estudavam no Tatuapé. E até eu tentei ir pra escola que eles estavam, mas não consegui. Aí, eu fui pro São Paulo. Mas eu fui pra lá já com a idéia de tentar dar um pouco mais de qualidade pros meus estudos. [...] Esses vizinhos têm a banca aqui na Avenida dos Metalúrgicos... [Quem me apresentou a série Vaga-lume] foi esse meu vizinho. Então, a mãe deles... Um livro que não vendia, material, sempre que vem assim com jornal, coleção, ela levava pra casa dela. E ela tinha meio que uma bibliotecazinha em casa. E o quintal dela também tinha um monte de coisa. E aí, esse meu vizinho, o nome dele é João, ele é o que mais ficava... Eu lembro que ele ficava falando de coisas e eu não entendia nada do que ele estava falando. E eu sempre querendo brincar e falava: “Ah, não enche o saco”, brincando. E aí, um dia eu parei pra ouvir o que ele estava falando, e ele falava de estudar, de universidade, de sociedade... Ele deve ser uns quatro anos mais velho que eu, só. E aí, ele é que falava sempre pra mim, e aí ele falava: "Ah, lê um livro" e ficava falando, enchendo o saco, e eu [respondia]: "Não, não gosto. Quero assistir televisão". E aí, eu fui cedendo, fui aceitando. E ele falava pra todas nós lá na rua. E aí, eu peguei esse livro e gostei. Deixei um pouco a televisão e fui ler. Aí, eu comecei. E aí, eu terminei de ler. E aí, eu entregava o livro pra ele e ele me dava outro. Ele [escolhia pra mim] e falava "Ah, desse eu acho que você vai gostar", porque pra mim... Até que ele começou a dar uns livros que eu achei muito difíceis. Ele me deu o Rousseau pra ler, $O$ contrato social, e eu não entendi nada. Daí eu falei: “Ah, não quero esse daqui não. Me dá aqueles outros lá". E aí, foi mais ele que foi me dando incentivo. E ele já fazia cursinho. E, no ano que eu comecei a me interessar mais por leitura, ele passou no vestibular...

Três sujeitos - AK47, Frida e Marley - referiram-se ao caráter fortemente constitutivo dos grupos de estilo, em particular do rap, cuja ideologia incluía incentivos à escolarização, à leitura, à reflexão e à escrita de suas próprias letras, a valorização da identidade negra, a busca de conhecimentos e até a freqüência a bibliotecas. Os 3 pesquisados identificaram-se profundamente com a temática e a linguagem dos raps e tornaram-se eles próprios compositores:

AK47: Não. Eu não participava do Força Ativa, eu não participava de nada. Eu tinha interesse num monte de coisas, mas eu acho que o que contribuiu também foi o hiphop. O hiphop, além de 
proporcionar uma série de reflexões e você começar a escrever músicas de rap, você tem contato com a escrita e com a leitura. [...] Isso foi com uns vinte anos, que eu comecei a me interessar em fazer rap.

Frida: Com certeza, [o hiphop e o rap também me incentivaram a ler], porque o rap, pra você saber escrever, você tem que ler. E eu escrevo e no rap você, pelo menos para mim, você não pode escrever qualquer coisa. Não dá para rimar um, dois, feijão com arroz. Pode até ser engraçado, mas não tem sentido. E o rap precisa ter algum sentido, para reivindicar, para dizer o que acontece e o que poderia acontecer. Eu acho que o rap é o grande incentivador, sim, para ler, para escrever, para se informar.

[Eu me envolvi com o rap quando] eu tinha uns quinze anos, [...] através daquela amiga que mora até hoje lá no CDHU. Ela começou a ouvir rap e ela começou a me dizer: "Ouve essa música". E aí, eu fui gostando e entendendo, porque no começo eu não entendia, né. Aí, eu fui conhecendo mais da história do hiphop, como ele surge. Então, eu fui me envolvendo, eram histórias parecidas com a minha e eu fui me aproximando. [...] Eu acho que $[\mathrm{rap}]$ é poesia, é literatura, é história. É um pouquinho de tudo, o rap. Mas tem essas três características: a poesia, a história e a literatura. É uma literatura diferente, alternativa e que retrata o cotidiano mesmo das pessoas. Tem muito rap antigo que tem muito a ver com hoje. Tem muita coisa, se você pegar, tem, né. O que eles falavam vinte anos atrás é hoje ainda.

Marley: Acho que [esse conhecimento vinha] da vivência, de algumas leituras, eu estava começando a ouvir rap. Quando eu ouvi pela primeira vez Voz Ativa. Aí, tem um som do Taíde que é rock, chamado Luz Negra, e que falava que Hitler não era negro e a bomba atômica não foi feita por nós. Mesmo assim, somos perseguidos como marginais, mas sei que para você tanto faz. É verdade: por que a gente é tão perseguido se não fomos nós que fizemos a bomba atômica? Então, comecei a refletir nessas questões. Na escola, assim eu não me via como protagonista de nada. Na história, então... Eu sempre odiei História. Minhas notas mais baixa era de História. [...] Eu percebi o quanto a gente realmente tem que correr atrás do conhecimento e compartilhar. Não adianta guardar só para si.

[...]

Nossa, eu era novinho [quando comecei no rap]. Uns onze, doze. Primeiro contato foi na [estação] São Bento [...] do metrô. Tinha uma galera dançando. Comecei a dançar primeiro, depois veio o rap. Eu disse: "Nossa! muito louca essa dança! Da hora!". Ainda mais todo mundo discriminando, julgando: "Ah, isso tá errado, fica aí rodando no chão, ai coisa de gente que não tem o que fazer, de maloqueiro, de negro". [E eu pensava:] "Mas e aí, eu sou o quê? Eu sou isso que vocês estão julgando". Diziam: "Não, você não, você é gente decente. Ah, gente decente? Gente decente não faz isso?" Aí, é que acabou fortalecendo mais: "Agora é que eu vou fazer mesmo, sabe?”. [...] O jovem gosta de ir contra. O adulto está dizendo que está errado? Ótimo!

$[\ldots]$

Eu acho que o rap ajudou [a incentivar a leitura], mas eu estava tudo contra, total. Minha pele era marrom clara ou morena, meu lábios eram beiço. Pessoal fala que negro tem beiço, não tem boca. $\mathrm{O}$ cabelo não é tão ruim. Então, não sou negro, firmeza. Tá bom, não sou. Já que eu não sou negro, eu sou o quê? Moreno. Aí, as meninas [diziam]: "Marley você é moreninho". [E eu refletia:] "Firmeza. Mas por que quando a policia me enquadra, ela não me chama de moreno? Nossa, [a polícia me enquadra] direto". [...] Eu pensava: "Meu, tem coisa errada nesse planeta, aí, e as informações não estão chegando. Eu estou aqui à deriva. Quero saber o que está acontecendo mesmo". E fui começando a pensar: "Quando eu vou para o centro, tenho que fazer trabalho na Biblioteca Municipal, trabalho de escola". Quando consegue achar algum livro aqui em Guaianases? Quando consegue. É estranho, quando estou na Avenida Paulista, eu tenho um jeito. Quando eu estou lá na Cidade Tiradentes tenho outro jeito". [...] E aí eu via que tem uma diferença na tonalidade da pele das pessoas também nessas áreas nobres. Sabe essa coisa de olhar e perceber? Tipo: "Tem alguma coisa nesse planeta que eu não estou entendendo. Ah, deixa eu começar a entender e onde que estão as informações”. Então, aí é que está a dificuldade [de obter informações]. Porque quando eu vi o rap, aquilo falava o que eu estava pensando. Falava da discriminação, do preconceito. Aí pensei: "É isso mesmo!". Aí, comecei a ouvir bastante o som e, na biblioteca, além do trabalho,eu comecei a ler alguma coisa à parte. Terminava o trabalho e fazia leitura complementar.

[...]

[Eu fui buscar informações] lá no meio do rap, lá na São Bento, [onde] tinha uns debates, uns diálogos e aí eu só fui participando. Quando nós mudamos para a Cidade Tiradentes, ficou mais longe a São Bento e eu fiquei muito bravo. A gente ia todo sábado lá. A gente montou um grupo de break chamado Citibreak, da Tiradentes. Então, a gente treinava e tal. Só que não era só dança, uma vez a gente estava lá, eu não tinha despertado direito o gosto pela leitura. Até que um dia um cara enorme, com o cabelo mais alto ainda, gigante,"blackão"... Eu pensei: “Nossa, quem é esse louco aí?”. Era o Nelson Triunfo, um dos pioneiros do hiphop do Brasil e aí ele chegou e falou: "E aí, molecada vocês estão aqui... Quem 
canta? Quem dança?”. Aí levantou a mão uma galera. “Quem toca, quem é DJ?”. Outra levantou a mão. "Quem grafita? Quem está na escola?". Aí a metade já levantou a mão. Ele falou: "Essa metade que não levantou a mão, não esqueça que vocês são o futuro. Se vocês não projetarem a vida de vocês, vocês vão para onde? Por exemplo, a maioria de vocês aqui são o quê? Qual a história de vocês?" E ele foi dando esses puxões de orelha. Aí, eu pensei: "É isso mesmo, o que ele está falando é o que eu estou em dúvida. Agora ferrou. Não, deve ter algum lugar para eu achar isso aí". Aí, eu cheguei nele e falei: "Ô cara, você falou nesse negócio aí, mas e aí, mano, onde estão essas paradas aí?". Aí, ele falou: "Cara, tem coisa que está aqui [apontando para o cérebro], aqui [apontando para o coração] e aqui [apontando para o livro]". [E eu perguntei:] "Não, firmeza. Esses dois aí já estavam, mas e esses livros aí?". [E o Nelson respondeu:] "Cara, é o seguinte, mano, vai lá na biblioteca. Tem coisa boa lá, mano. Não fica esperando, não. Mas na escola também tem coisa boa, mas você tem que aprender a ler. Porque você não pode ficar negando a leitura, conhecimento está lá. Você tem que conhecer tudo."

A mediação de leitura no grupo de estilo rap aconteceu com freqüência no mínimo semanal, chegou a ser diária em alguns casos, e alongou-se por vários anos. No caso de alguns sujeitos, como Marley, por exemplo, a influência do rap confunde-se com a do que viria a ser posteriormente aquela do movimento social Força Ativa, para o qual ele migraria com cerca de 17 anos, já que, conforme dissemos antes, o referido movimento surge de uma posse de rappers.

É essencial pontuar que os rappers que viriam a formar o Força Ativa atribuíam ainda maior importância à leitura e à busca de conhecimento do que a maioria dos rappers, conforme explica um dos sujeitos:

\begin{abstract}
AK47: O pessoal sempre falava da importância da leitura porque eles vinham desde o ano de 1995 aqui na Cidade Tiradentes fazendo essa discussão, né. Dentro do hiphop, a importância do pessoal do hiphop não ficar só falando sabedoria de rua e ir atrás do conhecimento, tanto é que eles tem uma música de rap que é Vamos ler um Livro, e toda vez que tinha uma apresentação de hiphop que o pessoal do Força Ativa fazia, cantava essa música, desde o ano de 1995. [...] Então, é assim, o pessoal no hiphop fica muito no campo descritivo do cotidiano, fica descrevendo muito o cotidiano violento, como é o jovem no tráfico, a questão do racismo e tal. Só que aí não pode generalizar porque o Força Ativa fazia essa discussão, como o pessoal discutia muito essa questão racial, se você não lê nada, você não sabe nada sobre questão racial e combate ao racismo. Então, é necessário você ir buscar nos livros, não tem outro meio. Não adianta ficar assistindo palestra e anotando. Tem um pessoal de hiphop que rotula o Força Ativa como que querendo ser os intelectuais do rap, porque a gente acha necessário a gente ir buscar a leitura. É lógico que a sabedoria de rua tem importância porque ela mostra o cotidiano, saber o que acontece é importante, mas não tem que parar nisso, não dá para descartar os livros e pensar que os livros não servem para nada e ficar só escrevendo e cantando músicas de rap. Tem um lado do hiphop que acha que não é importante e a gente bate na tecla de que é importante.
\end{abstract}

Para ilustrar a relevância que a leitura tinha para os rappers que vieram a formar o Força Ativa, citamos novamente um trecho do rap "Vamos ler um livro", ao qual AK47 aludiu acima:

Comuna Força Ativa, pois não queremos ser os tais

Pois sabemos que a boa leitura ensina até demais

Portanto, meu amigo, procure se informar

Pois do jeito que está, não, não pode ficar

São tantos sem cultura, sem conhecimento pra trocar

A leitura é importante, o livro é arma fatal

Que acaba com a ignorância, deixa sua mente legal. 
Em síntese, depreende-se dos depoimentos que, na constituição leitora dos sujeitos, o fenômeno do rap como um todo e o contato com outros leitores assumiram grande relevância. É preciso ressaltar, contudo, que, no universo de relações dos sujeitos, o número de vizinhos, colegas e amigos leitores parece ter sido bastante reduzido.

\subsubsection{A mediação de leitura pelo grupo de pares - Grupo B (os leitores de literatura)}

Como vimos anteriormente, no grupo B, 2 sujeitos - Beatriz e Malik - citaram colegas na escola onde fizeram o Ensino Fundamental e Médio. Na interação com tais amigos, houve incentivo mútuo à leitura e interlocução sobre as leituras realizadas. Para Malik, tal interlocução esteve vinculada também ao acesso a material impresso. O contato com os mediadores foi bastante freqüente, e, às vezes, diário e se estendeu por pelo menos 2 anos. Dentre os colegas de escola citados por Malik, houve um leitor mais velho e mais experiente, cuja mediação de leitura foi alvo de análise quando tratamos da escola.

Dentre os 5 sujeitos do grupo B, 2 - Beatriz e Malik - fizeram referência aos namorados. A mediação de leitura do namorado de Beatriz consistiu de incentivo à leitura, interlocução sobre as leituras realizadas, intercâmbio de livros e até visitas a livrarias (sem aquisição, porém). Tal namorado foi modelo de leitor - entre outros gêneros - de obras clássicas da literatura e dono de biblioteca pessoal.

Beatriz: Ah, eu já fui [a uma livraria], mas nem com minha mãe e nem com a minha tia. Eu fui sozinha, já fui com meu namorado mesmo. Eu ia com ele, a gente entrava... [O meu namorado também] gostava [de ler]. [A gente namorou] três anos... [A gente] falava [de livros], ele gostava muito de ler. [...] E aí, ele me emprestava porque ele sempre teve um monte de livro e de literatura, ele gostava de literatura, que ele tinha um monte de livro de literatura e livro espírita. E aí, a gente trocava livro assim e comentava as histórias. [...] Ele também me emprestava livro. Com certeza, [um incentivou o outro a ler]. Ele tinha tanto livro de literatura. Era muita coisa que ele tinha de literatura. Era mais literatura do que livro espírita, na verdade. E ele tinha muito. Ele lia bastante literatura.

A namorada de Malik estimulou fortemente a continuidade de sua escolarização na universidade pública, o que levou o sujeito a ler muito mais, com vistas a passar no vestibular e a freqüentar cursinhos preparatórios, os quais favoreceram o acesso a material impresso e interlocuções com mediadores refinados, os seus professores:

Malik: E aí, eu comecei a ler mesmo, ler de verdade mesmo, quando foi para fazer vestibular. [A minha namorada] era roqueira [...] e, para me aproximar dela, eu me aproximei mais ainda do rock. Olha só que picareta! Nisso, eu comecei a ler um pouco sobre a história do rock só para conseguir... Bem picareta, mesmo. Lia sobre Pink Floyd. [Eu lia isso] em revista e só de ouvir, eu perguntava para ela mesmo. Pegava aquelas revistas antigonas e ia ler já com uma certa criticidade e questionava coisas que o rock dizia. [...] E, com esse arremedo de crítica, eu me aproximei dessa namorada e aquela coisa do 
rock que não era tão rebelde assim. Era mais algo para ser vendido. Esse namoro com a Rosângela, essa aproximação com o rock e essa crítica assim, uma vez nós debatemos a universidade e eu disse o que você falou ali dentro, que USP era lugar para boy, isso já era o ano 2000. Eu disse: "USP é lugar para boy, pobre como eu não estuda na USP". E ela disse: "Se você não tentar, você não vai entrar". Eu falei: "Beleza, eu vou tentar, mas não vou conseguir, porque aquele lugar já está pré-determinado a quem tem condições de estar. Quem não tem é um acidente”. Então, ela me disse: “Então, seja um acidente!”. E eu acreditei nessa de auto-ajuda [risos]. E aí, eu fui com ela e mais outros amigos procurar um curso no SENAC, [...] curso técnico de contabilidade, para eu me aperfeiçoar na área. Daí, custava duzentos e cinqüenta reais e aí ela falou: "Não, tenta fazer um vestibular, tenta qualquer coisa". Descemos até a escola onde eu estudei, que foi no Tatuapé, foi tudo no mesmo dia desse debate, o debate sobre a universidade pública. Quando eu debati com ela e com outro garoto que a universidade pública era elitizada e não me cabia lá, a gente estava no caminho para ver o curso no SENAC. E, quando eu entrei no SENAC, e quando eu vi que o curso era caro, saí de lá desesperado, pensando: "O que eu vou fazer da vida? Não quero ser ajudante geral para o resto da vida". [Eu tinha] dezenove anos. Já o ensino médio tinha ficado para trás há dois anos. Daí, fomos até a escola onde eu estudava só para pegar o histórico e daí lá tinha uma cartazinho da EDUCAFRO Pré-vestibulares. Eu peguei o endereço e ela cutucando: "Vai, vai para a universidade, tenta, presta o vestibular, olha, esse cursinho é gratuito, é dez por cento do salário mínimo, tenta fazer alguma coisa". Aí, eu fui. Comecei a estudar na EDUCAFRO lá no Tatuapé, também. Mas aí já não dava mais para segurar e aí eu comecei a ler uns negócios. Eduardo Galeano, eu lia Eduardo Galeano e pedia para a professora de Geografia da EDUCAFRO alguns textos. E aí, ela meu deu o livro do Che Guevara, ela me deu o livro.

A mesma namorada foi indiretamente responsável pela inserção de Malik no grupo de estilo do rock, onde novamente o acesso a material impresso e as interlocuções sobre leituras foram favorecidos:

Malik: E daí, um outro amigo, que era da banda de rock que eu cantava, eu cantava rock, minha cabeça
já estava virada mesmo... e esse meu amigo, baterista da banda de rock, para me comprar para que eu
fosse vocalista, ele me deu o livro Biografia de Nelson Mandela. Aí, eu li a biografia de Nelson
Mandela, a do Che Guevara. Foi tudo casando no ano de 1999 e no ano de 2000 , que eu li a biografia do
Nelson Mandela, aquela coleção de livros de bolso, que tinha o do Che Guevara e Veias Abertas da
América Latina, isso mais tarde. Entre o ano de 1999 e o ano de 2001 , acho que essas três obras assim é
que onde eu fui adentrando. A biografia do Nelson Mandela, a do Che Guevara e Veias Abertas da
América Latina. Malik, a exemplo de Zapata, beneficiou-se também da mediação de leitura exercida pelo fenômeno do rap. Tal mediação consistia de algo mais difuso - presente nas letras das músicas veiculadas que se tornaram mais famosas, as quais incentivavam a escolarização ou, ao menos, a busca por conhecimento, a leitura e a reflexão - e também de interlocuções com leitores mais experientes nesse grupo de estilo. Consistia ainda da análise literária das metáforas e intertextualidades das próprias letras de rap. As dificuldades na compreensão dessas letras instigavam Malik a buscar mais conhecimentos:

Malik: Aí, eu já estava envolvido com o rap até o último, mas estava com a banda de rock e o que o rap me falava me instigava a ler. A música era do Consciência Humana, o disco era Entre a Adolescência e o Crime e a música era... A música que eu estou falando era do disco Adolescência e o Crime que ele falava para a polícia: "Policiais otários, fardados, não, sem nível de faculdade". Daí, um cara que era filho de policial falava: "É, mas se eles estão falando que "rapeiro" não tem faculdade, o que eles estão falando?". Eu respondi: "Mas o que ele está falando é outra faculdade, não é nível universitário". Então, ele disse: "Então, explica melhor". E eu não conseguia explicar que essa faculdade era a possibilidade 
de optar por algo, que ele estava falando para o policial que ele não tem nível de faculdade, mas ele não tem escolha, ele está lá para matar. Era o que o cara dizia e eu não conseguia explicar isso. Eu tinha que entender isso e foi a música que me desafiou a começar a ler. Daí, eu fui ler e entender desse desafio, dessa música, o que as músicas queriam dizer de verdade. Porque aí os caras falavam em Estado e eu não sabia o que era o Estado. Para mim, era só o estado de São Paulo, Rio de Janeiro, Minas e eu tinha que entender o que era o "braço armado do Estado" que eles falavam. E aí, eu fui começar a ler os negócios e aí eu comecei a ter contato com literatura punk e tudo que eles escreviam foi entrando e aí comecei a ler.

$[\ldots]$

Eu já tinha tido contato com o pessoal do MST para escrever uma letra de rap, mas com o som de rock. Eu fui na Secretaria Nacional do MST, na Barão de Limeira, e aí, eu conversando com eles, eu disse: "Eu quero material de vocês, porque eu quero conhecer vocês para poder fazer uma música para homenagear a luta de vocês". E aí, eles me deram um livro de um cara que foi meu professor na UNESP, me deram isso. O livro chamava Minha Brava Gente e me deram um monte de livros, livros e cartilhas do MST e aí eu já estava lendo muita coisa.

O fenômeno do rap disseminou conhecimentos sobre figuras históricas negras, que, apesar de importantes, não eram apresentadas pela escola nem pelos movimentos sociais ou partidários. Além disso, apresentou a leitura como uma alternativa à exclusão, à marginalização:

Zapata: E tem outra coisa muito importante que ia passar batido do rap, que contribuiu muito para que eu lesse, que eu já lia, né. Mas o que contribuiu mesmo foi um tal de disco chamado Escolha seu caminho. Putz, chorou. É que ele [referindo-se a Marley] chora quando ele escuta esse nome. Esse disco chamado Escolha seu caminho [...] foi importante porque o nome do disco era Escolha seu caminho e os caras sempre batiam nessa tecla de ler, de se informar. [...] Então, muita gente, posso afirmar para você, muita gente que hoje da nossa idade lê [...], na vida de muita gente na periferia, teve influência esse disco. Inclusive de conhecer Zumbi dos Palmares. O nome do disco é Escolha seu caminho, só que no disco só vem duas músicas [...]: Tinha a Voz Ativa, que era uma música muito boa e a Escolha seu Caminho. [...] E aí, nem o Movimento Negro, nem o partido que falava de esquerda e muito menos a escola, é lógico, conseguiu mostrar para a periferia quem foi Malcolm X, quem foi Martin Luther King, quem foi o Zumbi dos Palmares. Isso só o rap e esses caras foram os principais. O Racionais e a Força Ativa que, na época, a gente ainda usava fralda. Mas também o disco Escolha seu caminho: a capa era de um lado um cara com arma ou injetando droga e do outro lado era um cara lendo aquele monte de livros. Por isso é que o nome é Escolha seu caminho. Muito boa essa música, influenciou eu e muita gente, o Marley com certeza. [Essa música] fala da importância de ler, né. Na verdade, o nome da música é Negro Limitado. Escolha seu caminho é o nome do disco, mas a música é Negro Limitado e a outra é Voz Ativa mesmo. Negro Limitado fala das opções, o que a sociedade oferece para o negro ou como ele sai disso. Ele fala: "Escolha seu caminho, seja um verdadeiro preto, culto, informado ou você é apenas um negro limitado". Inclusive ele diferencia preto de negro. Porque hoje para ele tem até o negro branco. E aí, quando a gente começou esse movimento do hiphop, não era assim do Movimento, mas já freqüentava, você via que isso aí muita gente pode ter certeza. [...] O Escolha seu caminho foi no ano de 1992. [...] Foi nessa época que esse livro aí forçou a busca de todo mundo para ler. Tanto pela música como pela capa que era uma capa assim... [muito simbólica].

Se a mediação de leitura pelo rap nos trechos acima diz mais respeito à ideologia, a algo mais difuso, presente nas letras de discos, o sujeito Zapata beneficiou-se de intensa e prolongada interlocução pessoal com um leitor muito mais experiente, o qual disseminou conhecimentos, recomendou obras e fomentou o debate sobre elas. Tal amigo, que, além de modelo de leitor, foi modelo de estudante, um típico representante da cultura letrada, estimulou insistentemente a leitura e a politização do sujeito diariamente por muitas horas e durante vários anos: 
Zapata: [Eu comecei a ler Marx] um pouco por influência [de meus irmãos] e um pouco também da época que começou a despertar a questão da indignação. Não só com os irmãos, mas também com outras pessoas, como o William. Ele era bem chegado com o meu irmão e eles tinham um grupo de rap. Ele era quem coordenava o grupo de estudo e a gente conversava muito também, indicava os livros. [...] O William, que é esse cara que eu já citei, [foi um modelo de leitor pra mim]. O William enchia meu saco com livro, também. Ainda bem, né. Eu debatia até mais com ele do que com meus irmãos...

$[\ldots]$

[Nesse tempo que trabalhei na padaria,] não [fiquei sem ler]. Lógico [que continuei lendo]. Não fiquei sem ler, nunca. Acho que, desde que começou, eu acho que foi o tempo que eu mais li, até mesmo mais do que hoje. Eu queria ler Marx, Lênin. Lia tudo, né. [...] Eu encontrei [o pessoal da militância] quando eu vim para cá [Cidade Tiradentes]. Na verdade, foi quando eu vim para cá. Logo em seguida, encontrei o pessoal, mas nunca deixei de ler. Lia mais do que hoje. [...] Eu comecei a ler aonde? Nas questões sociais, comecei a ler isso, com dezesseis, dezessete [anos]. Comecei a ler isso, como eu falei o primeiro livro, livro mesmo que eu peguei e li de ponta a ponta foi A história da riqueza do homem, do Leo Huberman e, depois disso, acho que já de novo umas quatro ou cinco vezes e tem um monte que eu comecei e não acabei, também. Por exemplo: A Idade da Razão, do Sartre, que era do William. [...] O Wilhão teve um papel importante na nossa formação. [...] O William é um cara tão influente que até de umas pessoas irem para a Fundação foi ele e foi o primeiro a estudar Ciências Sociais na Fundação. Ele faz parte hoje, ainda, obviamente que nós temos divergências muito aprofundadas. Não é porque tem divergência que vamos esquecer que ele teve um papel importante, inclusive eu trabalhava na padaria à noite e ele ficava lá a noite inteira conversando comigo, o William. Porque o William sempre foi um cara solitário. E aí, ele ia porque a padaria era perto e a casa dele era em frente à minha. Eu trabalhava à noite, lá no fundo, fechada a padaria e aí eu abria e a gente ficava conversando tudo o que a gente conversa hoje. Falando da sociedade, se queixando, falando mal de um amigo, de outro. Falando dos livros, dos textos, depois que ele entrou na faculdade também acompanhando as novidades, falando do PT. Ele se formou em Ciências Sociais. E ele fez o Fernando estudar isso, porque ele e o Fernando são praticamente da mesma idade. Tinha um grupo de rap. E ele hoje ainda faz parte do grupo de estudo do Força Ativa e os que foram primeiro para o Força Ativa foi ele e o Fernando. Eles que conheceram. Ele foi coordenador até pouco tempo e aí ele renunciou à coordenação, mas continua... [O Wilhão foi] um dos [interlocutores mais importantes para minha formação intelectual], sem dúvida.

Álvares, assim como Zapata, teve contato durante vários anos - quase uma década com outro interlocutor leitor muito experiente, representante por excelência da cultura letrada, que ele conheceu, não no grupo de estilo rap, com o qual nunca esteve envolvido, mas por acaso numa igreja católica no centro da cidade. O sujeito tinha 18 anos e, já ateu, buscava em tal igreja um refúgio silencioso para ler. Ele chegou a nomear espontaneamente a relação que se estabeleceu com esse leitor 10 anos mais velho e muito escolarizado como sendo de "mestre-discípulo". O contato com tal mediador foi diário durante vários anos, e, embora com menor freqüência, perdurava até o momento da entrevista:

Álvares: Quando eu estava entrando na universidade, eu conheci um rapaz chamado Marcos. E esse
Marcos já estava fazendo mestrado em Filosofia na PUC. Eu conheci ele na Igreja Santa Efigênia e aí
eu estava lendo lá e depois fui visitar a casa dele e na casa dele tinha uma biblioteca enorme de
Filosofia, Sociologia, literatura, tanto é que o Crime e Castigo que eu tava lendo foi dele, que é a
tradução que vem direto do russo, que é do Paulo Bezerra. Aí, ele meu deu acesso e eu comecei a
conversar com ele e nesse caso, ele é a pessoa intelectual mais aplicada que eu conheci, ele lia oito
horas por dia. E ele ficou dois anos dentro daquele sistema que ele recebia mil e pouco. [...] Ele tinha
uma bolsa de mestrado e ele lia com disciplina, oito horas por dia: 4 horas de manhã e 4 horas à tarde.
Ele fazia disso uma profissão. Ele lia oito horas por dia, ele podia ler, né. E ele era uma pessoa
extremamente nobre. Ele fez um trabalho sobre o Thomas Khum, um livro de Epistemologia, tanto é
que eu primeiro fiquei oficializado na História foi quando ele terminou o mestrado dele, que ele se 
formou em Ciências da Religião na PUC, ele colocou até meu nome nos agradecimentos. Aí, eu falei: "Ah, agora eu estou na História" [risos].

[...]

Quando eu conheci [o Marcos], eu tinha dezoito, ele tinha dez anos a mais do que eu, ele tinha vinte e oito. E ele ficou seis ou sete anos no sacerdócio, fez faculdade, estava terminando, tanto é que ele lia muito, muito. [...] Aí, eu trabalhei para ele de corrigir as provas de universidade dele. Isso aí você não precisa colocar [risos]. E aí, ele me ensinava, eu lia os livros e eu corrigia provas de gente que estava na universidade, eu ajudava... [incompreensível]. Era tipo um secretário. Eu trabalhei pra ele. E aí, foi me ajudando porque... leituras, leituras, leituras.

$[\ldots]$

Faz mais de dez anos que eu tenho contato com ele. [...] A gente tinha um contato muito forte, muito constante, mas só que aí a gente tinha uma relação meio mestre-discípulo. Ele era meu mestre entre aspas e eu era discípulo rebelde e a gente acabava tendo algumas, algumas, algumas discordâncias em algumas coisas, tanto é que ele falava que ia montar uma casa e ia me levar para morar com ele. Ele ia morar comigo também e com a Eli também, a gente ia montar uma biblioteca. Meu sonho era ter uma biblioteca que dá de frente pra um jardim. É o meu sonho, eu sou apaixonado por livro, por todo o conhecimento humano. Eu queria absorver o máximo. Para mim, eu tenho pouco tempo: a vida é muito curta para eu absorver tantas coisas.

No grupo B, uma pesquisada - Taiko - não se lembrou de nenhum colega que tivesse contribuído para sua constituição leitora. Parece, no entanto, saber da importância do contato com mediadores mais experientes, pois ressaltou que busca estabelecer relações com pessoas mais escolarizadas nos cursos e palestras promovidos pela EDUCAFRO e instituições semelhantes.

Em resumo, 4 dos 5 sujeitos do grupo B tiveram oportunidade de conviver com leitores mais maduros entre seus amigos e namorados. $\mathrm{O}$ grupo de estilo foi um âmbito que favoreceu enormemente o contato entre os leitores.

\subsubsection{A mediação de leitura pelo grupo de pares: comparando os grupos A e B}

A análise das interações com os vizinhos, colegas, amigos e até namorados dos sujeitos evidencia a existência de muitas semelhanças entre os grupos A e B. A primeira delas diz respeito à inegável contribuição à constituição leitora dada pelo fenômeno do rap como um todo a 5 dos 13 sujeitos de minha pesquisa, em ambos os grupos ${ }^{96}$. A segunda semelhança relaciona-se à importância que 6 pesquisados ${ }^{97}$, também de ambos os grupos, atribuem aos leitores mais experientes com os quais tiveram oportunidade de conviver.

No grupo A, apenas 2 sujeitos - Laís e Maria - relataram ter convivido com leitores mais velhos e mais experientes. E somente Maria parece tê-lo feito por mais tempo e com maior freqüência. Já no grupo B, 3 sujeitos - Álvares, Malik e Zapata -, antes de conhecerem a BCST, sofreram intensa e prolongada influência de leitores mais velhos e mais experientes

\footnotetext{
${ }^{96}$ Trata-se de AK47, Frida, Malik, Marley e Zapata.

97 Álvares, Beatriz, Laís, Malik, Maria e Zapata.
} 
e muito mais escolarizados, os quais constituíram mediadores mais refinados da cultura letrada. Trata-se de Marcos, João e William, que os sujeitos conheceram em diferentes âmbitos: na igreja, na escola e no rap, respectivamente. Beatriz, por sua vez, conviveu durante 3 anos com o namorado que não sabemos se era mais velho ou mais escolarizado, mas que era um leitor mais experiente, dono de biblioteca e apreciador, entre outros gêneros, de literatura brasileira. O contato dos 4 sujeitos com tais mediadores leitores mais experientes parece ter contribuído muito para sua constituição.

Usando os critérios de faixa etária, experiência leitora e escolaridade, os quadros abaixo tentam evidenciar as diferenças entre os grupos A e B quanto à interlocução com vizinhos, colegas, amigos e namorados. Comparando-se os grupos, é possível dizer que, de modo geral, a maioria dos sujeitos do Grupo B teve mais oportunidades de interagir com leitores mais experientes e escolarizados, que constituíram mediadores mais qualificados da cultura letrada:

\section{Grupo A (leitores)}

\begin{tabular}{|c|c|c|c|c|}
\hline Sujeito & Amigos leitores & Faixa etária & $\begin{array}{l}\text { Experiência } \\
\text { como leitor }\end{array}$ & Escolaridade \\
\hline \multicolumn{5}{|l|}{$A K 47$} \\
\hline André & Colegas da mesma série & Semelhante & Semelhante & Semelhante \\
\hline \multicolumn{5}{|l|}{ Dandara } \\
\hline Frida & Colegas da mesma série & Semelhante & Semelhante & Semelhante \\
\hline Laís & Vizinho & Mais velho & Maior & \\
\hline Maria & Vizinhos & Mais velhos & Maior & Maior \\
\hline Marley & Vizinho & Semelhante & Semelhante & Semelhante \\
\hline Paula & Colegas da mesma série & Semelhante & Semelhante & Semelhante \\
\hline
\end{tabular}

Grupo B (leitores de literatura)

\begin{tabular}{|c|c|c|c|c|}
\hline Sujeito & Amigos leitores & Faixa etária & $\begin{array}{l}\text { Experiência } \\
\text { como leitor }\end{array}$ & Escolaridade \\
\hline Álvares & Marcos & 10 anos mais velho & Muito maior & Muito superior \\
\hline \multirow{2}{*}{ Beatriz } & Colegas da mesma série & Semelhante & Semelhante & Semelhante \\
\hline & Namorado & & Maior & Ignorada \\
\hline \multirow[t]{3}{*}{ Malik } & Colegas da mesma série & Semelhante & Semelhante & Semelhante \\
\hline & João & Mais velho & Muito maior & \\
\hline & Namorada & Ignorada & $\begin{array}{l}\text { Aparentemente } \\
\text { maior }\end{array}$ & Ignorada \\
\hline \multicolumn{5}{|l|}{ Taiko } \\
\hline Zapata & Amigo do rap & Mais velho & Muito maior & Muito superior \\
\hline
\end{tabular}


Diante de tudo o que foi dito pelos sujeitos, de todas as pistas que nos deixaram acerca de sua história como leitores, cabe chamar agora aqueles autores que fundamentaram o meu olhar, nesta pesquisa, a fim de compreender as estatisticamente improváveis e, por isso, paradoxais, constituições leitoras dos pesquisados, algo que farei no capítulo a seguir. 
Capítulo 5

Considerações finais

Pesquisar é isso. É um itinerário, um caminho que trilhamos e com o qual aprendemos muito, não por acaso, mas por não podermos deixar de colocar em xeque 'nossas verdades' diante de descobertas reveladas, seja pela leitura de autores consagrados, seja pelos nossos informantes, que têm outras formas de marcar suas presenças no mundo. Eles também nos ensinam a olhar o outro, o diferente, com outras lentes e perspectivas. 


\subsection{A resposta às questões que nortearam a pesquisa}

Minha pesquisa, cujo objeto era a constituição de leitores de livros e de leitores de literatura em meios populares, foi norteada por dois grupos de questões: a) o que influenciou a gênese do interesse por ler? A frequiência de acesso a material impresso e sua qualidade tiveram algum tipo de influência? e b) qual foi a freqüência da interação com os mediadores leitores mais experientes? O contato foi constante, esporádico ou até mesmo único? Em que âmbito e como aconteceu a mediação?

Para responder tais grupos de questões, retomarei sinteticamente os dados dos depoimentos coletados quanto a acesso, mediação pela família, escola, bibliotecas, grupos de pares e instituições religiosas.

Conforme foi possível observar no capítulo anterior, a resposta à primeira questão - o que influenciou a gênese do interesse por ler - é complexa, já que o processo de constituição leitora não se dá de modo homogêneo, linear nem tampouco mecânico. Os dados obtidos nos autorizam a afirmar que o paradoxo da constituição de leitores em condições de formação tão adversas foi possível graças a configurações sempre complexas e singulares de fatores interdependentes que contribuíram para a gênese do interesse por ler. A frequiência de acesso a material impresso e sua qualidade tiveram, sim, grande influência. Também exerceram grande influência o caráter de entretenimento desse material - em especial, na infância -, a identificação com a temática de algumas obras - em particular com as condições de classe de seus protagonistas -, e, por outro lado, o caráter exótico de outras obras, que levaram o leitor a vislumbrar outras possibilidades de vida. Para a maioria dos sujeitos, as oportunidades de contato com leitores mais experientes foram relativamente reduzidas e, para alguns, elas estiveram no terreno do imponderável. Quando esse contato veio a se dar e aconteceu com relativa constância e de modo prolongado também foi extremamente importante para a constituição leitora. O convívio com tais leitores mais maduros deu-se em diferentes configurações de âmbitos, os quais assumiram diversos graus de importância na constituição leitora de cada um. Os sujeitos que não tinham tido oportunidade de conviver com tais leitores mais experientes na família, na escola básica, entre os vizinhos, namorados, ou no grupo de estilo, encontraram-me na biblioteca comunitária (BCST) e no movimento social Força Ativa.

De modo geral, os sujeitos leitores tiveram acesso muito restrito a material impresso durante longos períodos de sua infância e adolescência, tendo dependido de empréstimos ou doações esporádicas, já que o acesso não foi garantido nem pela escola nem pelas bibliotecas pública ou escolar nem pela família. Assim, o acesso a material impresso pelos leitores deu-se 
mais tardiamente e, para a maioria deles, de modo mais contínuo apenas a partir de cerca de 17 anos, quando passaram a freqüentar a BCST.

Já para os leitores de literatura, o acesso a material impresso foi menos restrito e, em alguns casos, até razoavelmente farto. Além disso, o acesso parece ter sido favorecido mais precocemente, ter tido um caráter mais contínuo e ter se dado num número maior de âmbitos. Dentre os âmbitos em que se deu o acesso, dentre os leitores de literatura, a família assumiu grande relevância, pois conseguiu adquiri-lo, tomou-o emprestado ou recebeu doações. Quando o material não esteve disponível no âmbito familiar, os sujeitos o conseguiram por meio da biblioteca pública ou escolar ou nos grupos de pares. Os sujeitos leitores literários foram envolvidos em práticas de leitura mais cedo, antes mesmo da alfabetização e/ou já nos primeiros anos do Ensino Fundamental. Além disso, parece não ter havido um tempo de real afastamento da leitura.

O fato de o acesso a material impresso ter se dado mais tarde no grupo de leitores e o fato de eles não terem lido gibis, literatura infantil ou juvenil contribuíram para a não superação de dificuldades quanto à compreensão da linguagem ou da temática de literatura no Ensino Médio, mesmo quando eventualmente ela foi apresentada com práticas pedagógicas não equivocadas.

Considerando-se, conforme disse antes, que os sujeitos leitores de literatura haviam se constituído leitores antes de conhecerem a BCST - ao contrário do que aconteceu com a maior parte dos sujeitos leitores -, é justo supor que a frequiência de acesso a material impresso teve, sim, muita influência sobre a constituição ou não de leitores. Assim, quem teve maior acesso tornou-se leitor independentemente do acesso a material que se deu mais tardiamente na BCST e da intervenção deliberada dos mediadores de leitura dessa biblioteca. Nesse aspecto, portanto, meu estudo corrobora os resultados estatísticos da pesquisa Retratos da Leitura no Brasil (2008), que apontam para uma correlação entre o poder aquisitivo, o acesso a material impresso e a formação de leitores.

As famílias dos leitores e dos leitores de literatura têm muito em comum, em particular no que diz respeito a uma outorga de grande importância à escola e a uma forte mobilização escolar pela maior parte delas. Como resultado dessa mobilização, os sujeitos leitores literários tiveram aproveitamento escolar muito bom ou excelente e a maioria dos sujeitos leitores, embora não tenha tido desempenho tão excepcional, esteve no grupo dos alunos que aderiam à moral do bom comportamento. Quanto à outorga de grande importância à escola pela família e sua mobilização escolar, minha pesquisa confirma os resultados dos estudos de Lahire (1997), Rego (2003), Viana (2007) e Oliveira (2008). A partir dos 
depoimentos, inferi que a outorga de importância à escola pela família era tamanha que acabou por atenuar nos sujeitos os efeitos da desinstitucionalização e da desestabilização da profissão docente, que haviam sido apontados por Dubet (1997, 1998) e Charlot (2008). Assim, mesmo quando a escola foi terrivelmente omissa ou equivocada em suas práticas, a maior parte dos sujeitos manteve-se nela e continuou a apresentar bom comportamento e aproveitamento escolar razoável ou bom (no caso dos leitores) e excelente (no dos leitores literários).

Mas, se há grandes semelhanças entre as famílias do grupo de leitores e do grupo de leitores literários, há também diferenças importantes entre elas no que diz respeito à contribuição para a constituição leitora dos sujeitos.

Entre os leitores, de acordo com os relatos, as práticas de leitura nas famílias da maioria dos sujeitos inexistiram ou foram parcimoniosas, devido ao número reduzido de leitores e ou à baixa freqüência com que a leitura era realizada. Havia ainda pouca diversidade de materiais de leitura e quase total ausência de livros. O incentivo à leitura esteve muito ligado à aposta na escolarização como fator de emancipação econômica $\boldsymbol{e}$ ascensão social, concepção de leitura que sobrepujou de longe quaisquer outras. A mobilização escolar foi de responsabilidade principalmente das mães, quer fossem ou não escolarizadas. As mães alfabetizadas também tiveram mais práticas de leitura que os pais. Os relatos evidenciaram ainda o papel exercido pelos irmãos mais velhos, para a escolarização e a mediação da leitura e o papel exercido por alguma pessoa da família ampliada que, por ser professora, e, portanto, representante da cultura letrada, tornou-se uma referência para os sujeitos.

Entre os leitores literários, nas quatro famílias em que houve práticas de leitura, elas foram desenvolvidas por um maior número de pessoas e com mais freqüência do que nas famílias dos leitores. O fato de haver mais leitores na família permitiu que o sujeito presenciasse mais momentos de interlocução sobre leituras que ele próprio ainda não havia realizado, sendo introduzido a elas pela oralidade. Também nas famílias dos leitores literários, houve uma maior diversidade de materiais de leitura e a presença muito evidente do livro. Apesar de ter havido forte estímulo à escolarização, o incentivo à leitura não esteve tão estritamente vinculado a um projeto escolar. E, embora o acompanhamento da escolarização tenha sido realizado principalmente pelas mães, a mediação de leitura foi exercida por um número maior de membros da família, que difundiram concepções de leitura também mais diversas. Em meio às práticas leitoras na família, desenvolveu-se nos sujeitos um desejo de 
imitação do adulto ou dos irmãos mais velhos e uma curiosidade quanto às suas leituras. Assim, ser adulto era ser leitor (SMOLKA, 1989).

As diferenças entre os leitores e os leitores literários no que diz respeito à família indicam como a existência de modelos de leitores no âmbito doméstico favorece a constituição leitora. Também nesse aspecto, minha pesquisa corrobora os dados de pesquisas quantitativas como a Retratos da Leitura no Brasil (2008).

Para ambos os grupos de sujeitos, a escola foi terrivelmente omissa quanto a seu papel de formação leitora: estar na escola não foi sinônimo de desenvolver práticas de leitura, seja porque elas não foram fomentadas, seja porque a apresentação que se fazia delas era pouco atraente ou bastante negativa, contaminada por concepções de leitura por obrigação ou como tarefa escolar desagradável e difícil. Lembrar-se de alguma prática significativa e prazerosa nesse campo foi exceção e não regra. Além disso, freqüentemente esse espaço não favoreceu o acesso a material impresso (a não ser por um ou outro colega) e, em muitos casos, nem mesmo ao livro didático. Para a maioria, a escola não propiciou o desenvolvimento de uma relação significativa com o saber e a cultura letrada. Se e quando a instituição escolar fez esse trabalho, foi de modo descontínuo e ele esteve vinculado à atuação de alguns poucos professores, o que lhe conferiu um caráter de imponderabilidade ou de aleatoriedade. A atuação de tais professores foi muito valorizada pelos sujeitos em seus relatos justamente em função de seu caráter de exceção. Nesse sentido, minha pesquisa confirma os resultados do estudo realizado pelo CENPEC e Litteris (2001) sobre o desejo dos jovens de interação significativa com alguns poucos professores "legais". Boa parte dos achados de minha pesquisa convergem também com os resultados dos estudos de Charlot (2001, 2005), Sposito (2008), Rego (2003) e Viana (2007).

Muitas vezes, a escola chegou a exercer um papel diametralmente oposto ao que se esperaria dela, impondo as mais variadas barreiras de acesso ao material impresso, à formação leitora e à própria escolarização. A responsabilidade pelo desenvolvimento de práticas de leitura recaiu exclusivamente sobre o professor de Língua Portuguesa. E apenas metade dos sujeitos pesquisados interagiu com outros leitores (para além desse docente) no ambiente escolar. A mediação pelo livro didático de Língua Portuguesa - mal utilizado ou de acesso não franqueado ao aluno - foi insignificante ou negativa para a maioria. Em suma, minha pesquisa evidenciou de modo contundente o caráter degradado da escola freqüentada pela maior parte dos sujeitos, conforme descrito por Peregrino (2006) e Sposito (2008).

Entre os leitores, a ausência de um trabalho de desenvolvimento de práticas de leitura parece ter sido muito mais longa. A inexistência de práticas de leitura ou sua interrupção no 
$2^{\circ}$. segmento do Fundamental aparentemente contribuiu para uma mediação muito malsucedida da literatura brasileira no Ensino Médio. Os períodos em que a escola favoreceu alguma prática de leitura coincidiram com aqueles em que os sujeitos não estudaram em Cidade Tiradentes. Em bairros menos periféricos, houve práticas pedagógicas de melhor qualidade e uma mescla de alunos de diferentes classes sociais, o que favoreceu o acesso a material impresso e o contato com algum colega leitor.

Em tal contexto, para os sujeitos do grupo de leitores, ter chegado a se constituir leitor, ainda que não leitor de literatura, foi algo estatisticamente improvável, e, portanto, paradoxal, que só se compreende analisando a configuração de uma interdependência de fatores em vários âmbitos para além da escola. Os sujeitos parecem ter se constituído leitores (e não sido formados) graças à mediação de leitura que se deu em âmbitos diversos fora do universo escolar - em especial, em outras modalidades de escolarização (como os cursos prévestibulares comunitários), os grupos de pares e, mais tarde, na biblioteca comunitária.

Nesse quadro escolar tão negativo, os sujeitos leitores literários parecem ter desenvolvido mais práticas de leitura no âmbito da escola do que os pesquisados leitores. E, embora a atuação da escola tenha sido objeto de inúmeras críticas por sujeitos de ambos os grupos (leitores e leitores literários), tenho quatro observações importantes a respeito das diferenças entre a trajetória escolar dos sujeitos dos grupos examinados.

A primeira observação é que a escola freqüentada pelos sujeitos leitores literários foi menos degradada que aquela a que tiveram acesso os sujeitos leitores, evidenciando as desigualdades internas aos sistemas de ensino na rede pública produzidas pela onda de expansão escolar (SPOSITO, 2008), um dos fatores que por si só já impediriam que se considerasse a freqüência à escola como um processo homogêneo, ressalva feita por Rego (2003) ao estudo de Lahire (1997). Tais desigualdades estiveram muitíssimo vinculadas à localização geográfica da escola: em bairros mais consolidados e centrais, freqüentemente a escola teve qualidade menos precária. Porém, essas desigualdades podem ter se dado no interior das próprias escolas do bairro de Cidade Tiradentes, em função da qualidade de atuação de alguns professores, seja porque estes tinham práticas pedagógicas mais adequadas, seja simplesmente porque permaneceram na escola por mais tempo, atenuando os efeitos da descontinuidade motivada pela ausência e/ou elevada rotatividade de professores.

A segunda observação é que as escolas menos periféricas também favoreceram o contato com alunos de outras camadas sociais, o que os levou a ter contato com outros universos sócio-culturais, nos quais a relação com o saber não estava tão estritamente 
vinculada ao emprego (CHARLOT, 2001, 2005), em que havia mais práticas de leitura e mais acesso a material impresso por empréstimos entre pares.

A terceira observação é que, enquanto a maioria dos sujeitos leitores relatou ter tido seu aproveitamento comprometido em algum momento de seu percurso escolar, os sujeitos leitores literários conseguiram ter um desempenho escolar e, em alguns casos, uma relação com o saber mais positiva, desde os primeiros anos da escolarização, seja porque capitalizaram os conhecimentos que a própria família - mais escolarizada - mediou, seja porque foram objeto de elogios por alguns professores e de práticas docentes mais comprometidas e desafiadoras. Minha pesquisa confirma ainda a importância da postura de acolhimento à criança pobre em sua chegada à escola e a influência dos anos iniciais da escolarização para a formação de uma auto-imagem positiva e para a emergência e a inserção do aluno numa espécie de "lógica do sucesso escolar". Para vários sujeitos, que se ressentiram de ser subestimados pela escola, ser bom professor significava ser exigente e instigar intelectualmente os alunos. Boa parte dos achados de minha pesquisa confirmam as conclusões a que haviam chegado Grotta (2000), Rego (2003), Viana (2007) e Oliveira (2008) em seus estudos.

A pesquisa Retratos da Leitura no Brasil (2008) indica a existência de um vínculo entre longevidade escolar e formação de leitores: quanto maior a escolaridade, maior a probabilidade do sujeito se tornar leitor. A comparação entre os grupos de sujeitos leitores e leitores literários de meu estudo aponta também que, independentemente do grau de escolaridade que o sujeito atingiu, um bom desempenho escolar e uma boa relação com o saber ao longo da trajetória escolar contribuem para sua constituição leitora. Tal comparação indica também que, quanto melhor tiver sido o desempenho acadêmico dos sujeitos, maior será a probabilidade de se tornarem leitores e leitores literários.

A quarta de minhas observações é que a mediação do livro didático de Língua Portuguesa foi positiva para a maioria dos sujeitos leitores de literatura, seja porque foi fonte de literatura seja porque o professor realizou uma boa mediação desse material. Isso é indício de que, a despeito dos riscos de equívocos na apresentação da literatura pelo livro didático e pela escola (ZILBERMAN, 2003; SOARES, 2004; PIETRI, 2007), de modo geral, no contexto de alguma ou de grande restrição de acesso a material impresso em que esses leitores se encontravam, haver livros didáticos foi muito mais positivo do que não haver. Para vários sujeitos desse grupo, o livro didático foi fonte importante de textos para leitura e, especificamente, de textos de literatura. 
Um último aspecto que emergiu dos depoimentos foi a relevância do grupo de estilo rap, dos cursos pré-vestibulares comunitários e da graduação para o desenvolvimento e aprimoramento de práticas e habilidades leitoras. Quanto ao grupo de estilo, ficou evidenciado fortemente na história de meus sujeitos um intenso processo de letramento em contexto extra-escolar, algo que pode ter se dado ainda durante a escola básica e que pode ter contribuído para a própria forma de o aluno lidar com o saber dentro da escola. Para alguns sujeitos, tiveram grande relevância os cursos pré-vestibulares comunitários e, num segundo momento, a própria graduação para a constituição leitora. Tal relevância de âmbitos para além da escola básica é indício de que a formação leitora da maior parte dos sujeitos leitores literários pela escola, embora melhor que aquela da maioria dos leitores, ainda ficou muito aquém do ideal, tendo sido complementada posteriormente. Nesse sentido, os dados de minha pesquisa guardam semelhanças com aqueles obtidos por Viana (2007), cujos sujeitos conseguiram chegar ao Ensino Superior, mas num tempo mais longo do que a média dos estudantes de classe média. Também meus sujeitos vieram a se tornar leitores refinados, mas freqüentemente sua constituição levou mais tempo.

A maior parte dos pesquisados conviveu com alguém externo ao universo familiar (algum namorado, vizinho, amigo ou colega no grupo de estilo) que era leitor. Mas há uma distinção importante entre os dois grupos: os sujeitos leitores literários tiveram oportunidade de conviver com pares que eram leitores mais maduros do que aqueles com os quais conviveram os sujeitos leitores. Esses leitores mais maduros tiveram grande relevância para sua constituição, tendo sido mediadores mais refinados da cultura letrada. A relevância que os sujeitos atribuem a esses leitores evidencia a importância das interações com indivíduos mais maduros do grupo para o desenvolvimento humano (VYGOTSKY, 1989 1991, 1996, 2003; OLIVEIRA, 1993; PINO, 2005).

No universo de relações da maioria dos sujeitos, o número de pares leitores foi bastante reduzido. Nesse contexto, o grupo de estilo foi um âmbito que não apenas favoreceu o letramento extra-escolar, mas também o encontro e o convívio com pares leitores. Houve uma inegável contribuição à constituição leitora dada pelo fenômeno do rap como um todo a 5 dos 13 sujeitos de minha pesquisa, em ambos os grupos (leitores e leitores literários). O rap, cuja ideologia incluía incentivos à escolarização, à leitura, à reflexão e à escrita de suas próprias letras, a valorização da identidade negra, a busca de conhecimentos e até a frequiência a bibliotecas, teve um caráter fortemente constitutivo. Os pesquisados identificaram-se profundamente com a temática dos raps - a "condição de ser negro, jovem e excluído" (SPOSITO, 1993, p. 168) - e sua linguagem, passando eles próprios por um processo de 
elaboração de suas vivências ao comporem suas letras (DAYRELL, 2005). Por estimular a reflexão do sujeito, a apropriação do conhecimento e a criação de uma interpretação alternativa dos acontecimentos (SPOSITO, 1993), o rap já constituíra por si um contexto de letramento extra-escolar, pois favoreceria a emergência de uma perspectiva metacognitiva (OLIVEIRA, 1995), o que explicaria as aprendizagens aprofundadas detectadas por Charlot (2001) nesse grupo. Mas, no caso do rap brasileiro, cuja peculiaridade é um arco mais abrangente de atividades, o caráter político e a preocupação com aspectos organizativos (SPOSITO, 1993), a militância, o envolvimento em projetos de transformação social e a organização do trabalho para tanto incentivou ainda mais o desenvolvimento de tal perspectiva metacognitiva (OLIVEIRA, 1995; RATTO, 1995). Minha pesquisa ilustra como sujeitos que não tenham desenvolvido muitas práticas de leitura podem ter se envolvido em práticas tipicamente letradas. Também no grupo de estilo rap, os sujeitos tiveram o acesso a material impresso e a mediação de leituras favorecidos.

No grupo de leitores, a biblioteca escolar inexistiu, esteve fechada ou ofereceu muita restrição de acesso durante toda ou a maior parte da trajetória escolar dos sujeitos. Nos raros momentos em que esteve aberta, o atendimento por ela oferecido foi pouco convidativo, não houve indicações de leitura, o acervo não circulou e os alunos não tiveram autonomia para manusear os livros. Além disso, seu acervo pareceu constituir-se, sobretudo, de livros didáticos e paradidáticos. Já a maior parte dos sujeitos leitores literários fizeram uso da biblioteca escolar, mas não durante toda a escola básica e sempre com problemas na sua mediação de leitura. Quando a biblioteca escolar existiu, consistiu mais de um depósito de livros do que de um centro de formação de leitores (SOARES, 2004). Apesar de ter funcionado precariamente, o acesso a material impresso que ela possibilitou - ainda que descontinuamente - foi essencial para a constituição leitora de ao menos três sujeitos.

A existência da biblioteca escolar e a possibilidade de visitá-la também estiveram vinculadas à localização da escola: quanto mais antigo e central fosse o bairro, maiores as chances de haver a biblioteca escolar e de ela funcionar melhor. Mudar-se para Cidade Tiradentes significava deixar de ter acesso a tal equipamento. Mais do que corroborar os dados da pesquisa Retratos da Leitura no Brasil (2008), que aponta que é a classe E que menos consegue fazer uso das bibliotecas, tal constatação causa indignação.

A grande maioria dos sujeitos leitores praticamente não utilizou a biblioteca pública durante toda a escola básica. Na sua relação com tal equipamento, os sujeitos leitores literários guardam semelhanças com os sujeitos leitores quanto ao fato de ter começado a 
freqüentá-la exclusivamente para realizar trabalhos escolares e quanto a algumas críticas que fazem à mediação de leitura pela instituição, considerada irrelevante ou negativa.

Mas novamente emergiram diferenças significativas entre os dois grupos: a maioria dos leitores literários fez uso de bibliotecas públicas durante praticamente toda a escola básica e não apenas para realizar trabalhos escolares, mas também por iniciativa própria ou de suas famílias, para fazer leituras de seu próprio interesse. Além disso, fizeram-no com freqüência mais elevada, algo que foi possível graças à localização mais central de suas casas ou de seu local de trabalho.

A postura nada acolhedora das bibliotecas públicas, aliada à falta de domínio dos protocolos de leitura naquele ambiente, à sensação de não pertencimento àquele espaço devido às diferenças de classe social, além da própria distância entre o local de moradia e esse equipamento, desfavoreceram a freqüência a ele pelos sujeitos leitores, em especial, por aqueles que nunca o haviam visitado na infância ou que tinham se limitado a fazer eventuais trabalhos escolares na biblioteca de Guaianases.

É possível dizer que a biblioteca comunitária BCST foi tão mais importante para a constituição leitora dos sujeitos quanto menos relevante tivesse sido a mediação de leitura nos âmbitos da família, da escola e das bibliotecas escolar e pública. Assim, a BCST teve uma atuação fundamental na constituição de 6 dos pesquisados do grupo de leitores, que não tinham consolidado práticas de leitura. Para a constituição dos outros leitores - 5 leitores literários e 2 leitores - seu papel não foi determinante.

A mediação de leitura que se deu na BCST foi poderosíssima para transformar nãoleitores em leitores, alguns dos quais fazem leituras de obras de ciências humanas de complexidade extraordinária. O sucesso da BCST para a formação leitora desses sujeitos residiu na qualidade da mediação de leitura que ela realizou, caracterizada por aspectos de caráter afetivo e cognitivo (GROTTA, 2000; REGO, 2003), aspectos esses de cuja falta os sujeitos de ambos os grupos haviam se ressentido nas bibliotecas pública e escolar e na instituição escola como um todo. Nesse sentido, a BCST, ainda que com poucos recursos materiais, acabou por realizar o trabalho que tais bibliotecas e a escola deixaram de fazer ou fizeram precariamente.

A mediação de leitura na BCST foi realizada por pessoas que eram modelos de leitor, com os quais os consulentes se identificavam e cujas práticas de leitura e capacidade de reflexão e argumentação buscavam reproduzir. Interessante ressaltar que a descrição feita por Grotta (2000) dos professores marcantes para a constituição leitora de seus sujeitos pode ser aplicada, no caso dos meus, não à maioria dos professores da escola básica, mas a alguns 
professores de cursos pré-vestibulares comunitários e, muito especialmente, aos mediadores de leitura da BCST que já integravam o Força Ativa. Assim como os sujeitos de Grotta nutriam grande admiração por seus professores quanto à forma de ser, de pensar e de ler, desejavam identificar-se com eles, o que buscavam por meio da leitura dos mesmos títulos lidos ou citados por eles, da imitação de suas formas de ler e do valor que atribuíam à leitura, os meus sujeitos, que viriam depois a se tornar leitores, admiravam e tentavam imitar os líderes do Força Ativa no interior da BCST. Se os professores dos sujeitos da pesquisa de Grotta configuravam-se como modelos de leitores, que angariavam a admiração dos sujeitos por seus conhecimentos e por sua relação muito positiva com o saber e a leitura, o mesmo se dava com os entrevistados de minha pesquisa com relação aos mediadores integrantes do Força Ativa, leitores mais experientes e representantes da cultura letrada. Assim, ainda que mais tardiamente, a BCST conseguiu reverter um quadro de improbabilidade estatística de formação leitora, contribuindo intensamente para a gênese de constituições leitoras paradoxais.

Algo que caracterizou fortemente a mediação de leitura realizada na BCST pelos integrantes do Força Ativa foi a intensa explicitação do caráter ideológico da língua e a apresentação da linguagem como uma instância de confronto (RATTO, 1995), o qual estimulou fortemente o pensamento descontextualizado, a perspectiva metacognitiva, que a escola aparentemente falhara em desenvolver a contento em várias crianças, as quais freqüentemente se questionavam, por exemplo, sobre o sentido de estudar não apenas literatura, mas também Geografia para além da cidade de São Paulo. O engajamento no movimento social Força Ativa, o desenvolvimento de novas ocupações nada mecânicas, o envolvimento no projeto de transformação social, além de favorecerem o letramento, deram sentido às novas aprendizagens, estabeleceram uma nova relação com o saber (CHARLOT, 2001, 2005). A nova relação que os sujeitos passaram a estabelecer com o saber assemelha-se ao primeiro processo identificado por Charlot (2005), ou seja, os sujeitos gradativamente adquiriram o habitus de estudar, ou seja, passaram a ler porque desejavam fazê-lo. Na BCST, a leitura se desvencilhou de sua aura negativa de tarefa escolar obrigatória desprovida de qualquer sentido que não fosse a nota. Os sujeitos passaram a vivenciar o prazer de saber e o sentido de saber (CHARLOT, 2001).

Além disso, a participação sistemática em grupos de estudos e a própria sociabilidade em torno da BCST acabaram por favorecer fortemente a disseminação de conhecimentos dos integrantes do Força Ativa mais antigos para os mais novos, que viriam a se tornar os leitores. Portanto, é possível dizer que o fato de passar longas horas na BCST, como aconteceu com os 
voluntários da biblioteca, e o fato integrar-se depois ao Força Ativa, como se deu com alguns dos voluntários, favoreceu a escolarização dos sujeitos leitores não apenas pela verbalização de incentivos à continuidade da escolarização no sistema de ensino oficial, mas principalmente pelo próprio ensinar cotidiano dos membros mais maduros do Força Ativa, que atuaram como verdadeiros professores.

Outro aspecto importante a ressaltar para a paradoxal constituição de leitores no interior da BCST e do Força Ativa é que, além da sociabilidade no grupo incentivar a leitura, uma participação mais efetiva, mais fundamentada, mais legítima nas discussões pelos membros mais novos demandava as práticas de leitura e de estudo de obras de ciências humanas. Compreende-se assim porque vários leitores, que julgavam difícil ler obras de literatura brasileira, estivessem tão dispostos a ler obras extraordinariamente complexas de filosofia ou sociologia.

Para a maioria dos sujeitos desta pesquisa, as instituições religiosas não parecem ter exercido papel importante para sua constituição leitora.

Conforme disse antes, a pergunta sobre o que influenciou a gênese do interesse por ler tem múltiplas e complexas respostas, já que o processo de constituição leitora dos sujeitos não foi linear nem mecânico. Para cada sujeito houve uma configuração de fatores que contribuíram para tal gênese. Essa configuração foi sempre singular e não necessariamente significou constituições leitoras nem constituições semelhantes. Assim, entre dois irmãos com idades próximas, socializados na mesma família, e que freqüentaram a mesma escola, um pode ter se tornado leitor literário enquanto o outro não. É esse o caso de Álvares provavelmente o leitor literário mais contumaz entre os pesquisados - e de seu irmão, um não-leitor de livros.

Mas há duas pesquisadas que evidenciam ainda mais a questão da singularidade envolvida nesse processo, dado o grau de semelhança que as une e o grupo de leitores que as diferencia nesta pesquisa. Trata-se de Paula e Beatriz, irmãs gêmeas, que tiveram as práticas de leitura bastante fomentadas principalmente na família e, de modo mais subsidiário, na escola, por um longo período. Ambas tornaram-se leitoras. Mas apenas Beatriz constituiu-se leitora literária, o que está provavelmente vinculado ao fato de Beatriz ter tido uma relação com a escola muitíssimo mais positiva desde o início do Fundamental, a ter namorado por três anos um leitor mais experiente, apreciador inclusive de literatura, e a ter sido mais influenciada pelo entusiasmo de uma professora substituta durante dois meses no Ensino Médio. A história de ambas aponta para a existência de semelhanças - ambas adoram ler mas também para a singularidade de cada configuração de fatores constitutivos das práticas 
leitoras - só uma supera com prazer as eventuais dificuldades de leitura dos clássicos da literatura e aprecia lê-los.

A análise dos dados da pesquisa leva-me a crer que a gênese do interesse por ler literatura foi influenciada por diferentes e sempre singulares configurações de fatores em interdependência: o convívio com leitores na família (Retratos da Leitura no Brasil, 2008); uma intensa valorização da escola pela família e uma mobilização escolar (CHARLOT 2001, 2005; LAHIRE, 1997; REGO, 2003), que transmitiu aos filhos a moral do bom comportamento (LAHIRE, 1997; OLIVEIRA, 2008;) e da necessidade de perseverar na escola, mesmo quando ela suscitou pouco prazer ou causou sofrimento, o que, de algum modo, favoreceu o desenvolvimento das competências leitoras mínimas; experiências de leitura prazerosa e significativa (OLIVEIRA, 2008) de literatura infantil e de gibis em contexto de forte afetividade em família ou nos anos iniciais da escola; um bom desempenho escolar desde os anos iniciais do Fundamental e, às vezes, uma relação mais positiva com o saber, os elogios por suas habilidades cognitivas, em particular de leitura, a percepção de si como um excelente aluno (GROTTA, 2000; REGO, 2003; VIANA, 2007) e a inserção numa espécie de lógica do sucesso escolar (VIANA, 2007); práticas pedagógicas que incidiram sobre a zona de desenvolvimento proximal do sujeito (VYGOTSKY, 1984, 1988), que só foram possíveis graças a uma certa continuidade do trabalho pedagógico pelo professor; a convivência com outros leitores, seus pares, e a emergência de uma sociabilidade em torno do livro; o contato com leitores mais experientes e a qualidade cognitiva e afetiva da mediação por esses leitores (GROTTA, 2000; REGO, 2003; OLIVEIRA, 2008). A grande diferença a separar minha pesquisa dos estudos de Grotta, Rego e Oliveira é que, ao contrário do que aconteceu no caso dos pesquisados nesses outros trabalhos, para meus sujeitos, muitas vezes os leitores mais experientes que mediaram a leitura não foram os professores, mas sim amigos na escola ou no grupo de estilo, namorados ou, no caso dos participantes leitores, os mediadores de leitura da BCST. Outros fatores importantes para a gênese do interesse por ler foram: a variedade e qualidade do material impresso, o poder de entretenimento do material lido, em especial, no Ensino Fundamental, o contato com literatura infantil e juvenil, e a leitura de adaptações dos clássicos.

A frequiência de acesso a material impresso também foi um fator importante, o qual exerceu muita influência para a constituição leitora dos sujeitos. Não por acaso, sujeitos que tiveram menos acesso a material impresso - a maioria dos componentes do grupo de leitores só viriam a se tornar leitores quando do contato com a BCST. Mas o acesso a material impresso, embora importantíssimo, não foi determinante por si só para a constituição de 
leitores. A força de atração do material impresso foi enormemente potencializada pelo contato com mediadores, em especial, os mais experientes.

A qualidade do material impresso também exerceu influência sobre a gênese do interesse por ler. Alguns sujeitos relataram não ter sido atraídos, já na infância, por gibis do tipo Turma da Mônica e ter apreciado gibis mais sofisticados como Astérix e Konan Interessante ressaltar que vários leitores disseram não se interessar por outras bibliotecas comunitárias porque o acervo delas não tem a mesma qualidade daquele da BCST, constituindo-se predominantemente de livros de auto-ajuda e livros didáticos.

Outro fator na gênese do interesse por ler foi a identificação com a temática da obra. Isso fica evidente pela decisão dos sujeitos de passar a ler a partir da leitura de uma única obra que tratasse de temas de seu interesse, em geral, abordando questões relativas a sua condição de classe, gênero etc. Um outro fator para o desenvolvimento do interesse por ler foi o contato com pares leitores na escola e/ou no grupo de estilo, em particular no rap e a emergência de uma sociabilidade em torno das leituras e de uma nova relação com a escola e com o saber.

Para os sujeitos leitores, que tiveram menos acesso a material impresso, seja porque ele era menos variado seja porque o acesso era mais raro, que presenciaram menos práticas leitoras na família, que freqüentaram uma escola mais degradada e omissa na mediação da leitura, que visitaram menos as bibliotecas escolar e pública, as interações que se deram na BCST foram fundamentais, não apenas porque realizaram um trabalho de mediação que a escola havia deixado de realizar e porque ofereceram um acervo de qualidade, mas porque deram sentido aos novos conhecimentos que a leitura proporcionava, difundindo as concepções de leitura para obtenção do conhecimento e leitura para emancipação do ser humano e transformação social, concepções essas que favoreceram enormemente a gênese do interesse por ler.

A comparação dos dados entre os grupos de sujeitos leitores e leitores literários evidencia a importância da frequiência elevada de contato com mediadores mais experientes. Eles estão presentes na história dos leitores literários durante a infância e adolescência, isto é, antes de conhecerem a BCST, e na história da maioria dos sujeitos leitores apenas quando a conhecem. Para a maioria dos leitores literários, tais mediadores estiveram presentes em âmbitos diversos: família, escola, grupo de pares e grupo de estilo. Para a maior parte dos pesquisados leitores, os mediadores de leitura mais maduros se fizeram presentes principalmente na BCST.

Sobre a frequiência de contato com os mediadores leitores mais experientes, minha pesquisa aponta o quanto eles foram importantes, em especial no contexto de escola 
degradada freqüentada pelos sujeitos. O número de mediadores leitores mais experientes foi muitíssimo reduzido para a maioria dos sujeitos e eles nem sempre foram os professores, normalmente considerados os agentes privilegiados de letramento. Durante a escola básica, o contato com mediadores mais experientes deu-se no âmbito da família, alguns poucos professores e alguns colegas na escola, além do grupo de estilo, em alguns casos.

Para muitos dos sujeitos, ter um interlocutor mais experiente esteve no terreno do imponderável e não do provável. Para aqueles que conviveram com leitores mais experientes, o contato fez tanta diferença porque a freqüência foi elevada. Esse é o caso também do membro da família ampliada que, embora fisicamente ausente, acabava por estar muito presente, como objeto de discurso na família (VIANA, 2007).

Em síntese, de modo geral, minha pesquisa confirmou algumas das conclusões de estudos anteriores sobre as relações com a escola e formação leitora no que diz respeito à prática de leitura prazerosa e significativa, à importância do convívio com leitores que são interlocutores ou modelos de leitores e à qualidade da mediação por eles realizada, em que aspectos cognitivos e afetivos se complementam. Boa parte de tais achados está presente nos estudos de Grotta (2000), Rego (2003), Sampaio (2005), Viana (2007) e Oliveira (2008). Como disse antes, o que diferencia minha pesquisa daqueles estudos é o fato de os modelos de leitores raramente terem sido os professores da escola básica. A ocupar esse vácuo de formação leitora deixado pela escola estiveram o grupo de estilo rap, a BCST, os cursos prévestibulares comunitários e, em alguns casos, a universidade.

\subsection{Alguns comentários finais}

A escola, conforme disse antes, teve dificuldades no cumprimento de seu papel de "descolamento" do cotidiano e da realidade imediata do aluno, de apresentação da temática dos textos literários, de ampliação de vocabulário e de auxílio à compreensão do registro culto da linguagem. O fato de não se realizar tal trabalho não foi uma opção adotada em nome da diversidade cultural ou da não adesão a um suposto preconceito lingüístico, mas sim uma omissão, omissão essa que prejudicou o desenvolvimento das competências leitoras de vários pesquisados, em especial dos sujeitos leitores. Tal omissão impactou negativamente também sobre uma possível continuidade de sua escolarização.

Cabe ressaltar que não se pode responsabilizar os professores pelas falhas na formação leitora dos sujeitos desta pesquisa. Concordo com Lajolo quando diz que "o professor não 
pode ser considerado [...] o vilão de toda essa história, o responsável pelos resultados de uma educação que só começou a melhorar institucionalmente há pouco tempo" (2003, p. 47), seja porque "o professorado é submetido a condições de trabalho incompatíveis com a formação continuada e o aprimoramento pessoal" (CENPEC; LITTERIS, 2001, p.33), seja porque enfrenta o questionamento de suas práticas (LAJOLO, 2003; CHARLOT, 2008), seja simplesmente porque, conforme os depoimentos dos sujeitos evidenciaram, muitas vezes, o próprio professor não era leitor.

Interessante pontuar que os poucos professores de Língua Portuguesa considerados bons pelos sujeitos tiveram práticas pedagógicas, de modo geral, bastante tradicionais. Elas consistiram de aulas expositivas, solução de dúvidas dos alunos e demonstração de interesse por eles. Apenas eventualmente um debate, a exibição de um filme ou a apresentação de algum seminário. Eles também foram bem avaliados pelos alunos quando preparam aula ou demonstraram ser organizados. Nesse sentido, é justo dizer que quando o professor fez o mínimo, o básico que se esperaria dele, isso já suscitou a apreciação de seu trabalho pelos sujeitos.

De qualquer modo, a despeito da estarrecedora omissão da escola como um todo para a formação leitora, estar na escola fez diferença. Minha pesquisa aponta fortemente para uma não nulidade da escola, que foi tão mais importante quanto menos práticas de leitura e menos material impresso houvesse no âmbito doméstico do sujeito. Além de algum contato com a cultura letrada por meio do professor em si, ela favoreceu o contato com algum par leitor. Não por acaso, Malik - o único sujeito em cujo lar inexistiam quaisquer práticas de leitura e que chegou a se tornar leitor literário - embora hoje muito politizado, praticamente não criticou a escola. Nesse aspecto, guarda muita semelhança com Francisco, o sujeito mais pobre da pesquisa de Rego (2003), o qual, por ver na escola a única porta de saída de sua condição social e de acesso a um universo cultural diferente do seu, apreciava tudo que a escola lhe oferecia.

Assim como aconteceu nos estudos de Rego (2003) e Viana (2007), também de minha pesquisa emergiu fortemente o caráter de imponderabilidade ou de aleatoriedade. Para a maior parte dos sujeitos, o acesso a material impresso, a freqüência a escolas menos degradadas, o contato mais contínuo com professores comprometidos e pares leitores, e a oportunidade de vivenciar mediações mais qualificadas estiveram no terreno do circunstancial, do aleatório, do acidental.

Se, conforme postula Vygotsky, a relação do sujeito com os objetos do conhecimento não é direta, mas mediada pelo outro, quem se constituiu leitor foi aquele que teve a 
possibilidade de acesso a livros e cuja mediação pelo outro qualificado foi suficientemente intensa e cativante - seja por aspectos cognitivos seja por aspectos afetivos. Houve possibilidades de constituição leitora em condições tão adversas quando certo tipo de mediação qualificada aconteceu e quando o sujeito dela se beneficiou ou, em termos bourdieusianos, a rentabilizou (VIANA, 2007). Nas palavras de Lajolo, "ninguém aprende a ler sozinho, e é importante observar como essa necessidade de mediação se manifesta na vida de cada pessoa" (2003, p. 48). É justo dizer que as estatisticamente improváveis - e, portanto, paradoxais - constituições leitoras nos meios mais empobrecidos são prováveis (ou possíveis) a partir de uma certa perspectiva de análise: o olhar da psicologia histórico-cultural, que postula a relação dialética e sempre singular do sujeito com o meio e o olhar da sociologia, quando se dedica a uma análise mais fina do que a das categorias macrossociais e tenta perceber configurações singulares de fatores em interdependência. Cabe-me dizer, porém, que foi provavelmente o desejo (utópico?) de que tais constituições leitoras viessem a se tornar prováveis também estatisticamente e de contribuir, ainda que minimamente para tanto, que me mobilizou a realizar a presente pesquisa.

A antropóloga francesa Michèle Petit (2008), a partir de dezenas de entrevistas com leitores na zonal rural e jovens de bairros marginalizados, demonstra a importância das bibliotecas públicas e de bibliotecários, mediadores de leitura e educadores para a formação de leitores e para a luta contra os processos de exclusão. Se no Brasil as bibliotecas de modo geral, conforme afirma Soares (2004) e conforme minha pesquisa evidenciou, não são centros de formação de leitores, a BCST o foi, a despeito de dispor de parcos recursos materiais.

A análise do trabalho realizado pela BCST aponta para o grande potencial que bibliotecas comunitárias pequenas - mas com acervo variado e de qualidade e com mediadores de leitura qualificados e mobilizados para a formação de outros leitores - teriam para a constituição leitora de crianças, jovens e adultos. Para a eficiente mediação da leitura na BCST, contribuíram: por um lado, uma certa identificação com o mediador que, por ser jovem e morador do bairro, era um semelhante do usuário; e, por outro lado, uma certa assimetria com o mediador que, por ser mais escolarizado e modelo de leitor, era diverso do consulente. Esse jogo de igualdade/diferença poderia ser muito profícuo para a constituição leitora. Além disso, a continuidade do contato mediador/consulente foi igualmente importante, pois permitiu que o mediador viesse a incidir sobre a zona de desenvolvimento proximal dos usuários da BCST.

Assim, além da óbvia necessidade de bibliotecas públicas na periferia, hoje praticamente inexistentes, há necessidade de fomento à instalação e manutenção de pequenas 
bibliotecas comunitárias, incrustadas nas áreas mais desfavorecidas da cidade, às quais os moradores pudessem chegar sem ter de fazer uso de transporte público. Tais bibliotecas - com um quadro de mediadores de leitura estável, composto por modelos de leitores com um bom nível de escolarização, que conhecessem seus usuários - seriam muito positivas para o fomento de práticas de leitura. Poderiam inclusive revelar-se mais eficientes que as hoje longínquas e impessoais bibliotecas públicas ou as iniciativas de biblioteca móvel (do tipo van ou ônibus) que eventualmente surgem. Parece-me haver necessidade de criação de políticas públicas que assegurem a sobrevivência das bibliotecas comunitárias já existentes e favoreçam a instalação de novas.

Além disso, já que a escola pública é provavelmente o serviço mais capilarizado no país, é desnecessário apontar para a óbvia e urgentíssima necessidade de assegurar a existência de bibliotecas escolares e a circulação de seu acervo, assim como é desnecessário dizer que tais bibliotecas devem poder ser acessadas pela comunidade ao redor delas e não apenas por seus alunos. É igualmente desnecessário reiterar que cada uma delas deveria contar com profissionais que, a exemplo do que acontece na BCST, fossem atendentes caracterizados por sua postura acolhedora, convidativa, e por uma mediação de leitura qualificada.

Retomando as discussões de Lajolo (2001) e Soares (no prelo) sobre o que seja literatura, interessante dizer que os sujeitos da BCST, seus modos de ler e sua seleção do que ler, demonstram que eles desejam, sim, ter o direito de escolher ler obras de cunho não popular. Embora alguns deles teçam críticas a algumas obras da literatura brasileira, posicionam-se sempre em favor da leitura do que há de complexo e desencorajam as leituras que, segundo eles, não "acrescentam nada", ou seja, daquelas que, na opinião deles, não favorecem a gênese de uma forma alternativa e mais qualificada de estar no mundo e de nele intervir. Nesse sentido, embora as origens do grupo Força Ativa residam numa forma de expressão popular - o rap -, seus líderes, em face da hierarquização dos textos e livros, desejam, sim, ler o que há de mais sofisticado entre eles. Em outras palavras, desejam ter acesso ao capital cultural das elites para utilizá-lo em favor de seu projeto de transformação social, em benefício das camadas populares.

Retomando a distinção dos tipos de leitura - funcional, de entretenimento e literária proposta por Soares (no prelo), é interessante pontuar que, conforme alertou a autora, os modos de ler não são excludentes. Assim, no contexto de intensa mediação e sociabilidade em torno dos textos e dos livros entre os membros do Força Ativa, o modo de ler, por exemplo, 
um extraordinariamente complexo texto de filosofia pode ser, além de funcional, de entretenimento, a despeito de seu caráter hermético para alguns.

Se minha pesquisa, de caráter exploratório, respondeu, ainda que de modo muito incipiente, algumas questões, suscitou várias outras. Como desdobramento de meu estudo, desejo investigar que visões os professores de Língua Portuguesa têm quanto à possibilidade de formação leitora de seus alunos nas camadas populares.

Acredito que há também necessidade de maiores pesquisas sobre a relação dos professores com a leitura e sobre o papel que os professores de modo geral e os de Língua Portuguesa em particular exercem para a constituição leitora de seus alunos.

Outro campo de estudo ainda pouco explorado são as bibliotecas comunitárias, sua mediação da leitura e o tipo de leitores que ajudam a constituir. Que características teriam leitores consulentes de bibliotecas comunitárias que tenham surgido por iniciativa de outros grupos juvenis, de outros movimentos sociais, de instituições religiosas diversas ou de particulares que simplesmente queiram compartilhar o seu acervo? Seriam interessantes também pesquisas que comparassem o tipo de mediação que se dá em bibliotecas comunitárias de tipos diferentes que atendem à população de um mesmo bairro.

Há necessidade também de maiores pesquisas sobre o papel exercido pelos atendentes de bibliotecas, de modo geral (públicas, escolares e comunitárias), o que poderia dar subsídios para mudanças nas políticas de fomento de acesso a material impresso e a programas de formação de tais profissionais.

Outro campo que merece ser investigado é o da formação leitora pelas instituições religiosas. Vários autores, dentre os quais estão Lajolo (2003), atribuem a tais instituições um papel privilegiado para a formação leitora nas camadas populares. Isso não foi evidenciado em minha pesquisa. Pode-se argumentar que isso teria acontecido dada a especificidade da biblioteca comunitária em que meu estudo de campo foi realizado. Porém, cabe também questionar se não tem havido um decréscimo na relevância que as instituições religiosas têm assumido para a socialização de crianças e jovens e, portanto, para a formação leitora.

Por último, imagino que seria interessante investigar uma concepção negativa da leitura que se mostrou presente em várias famílias tanto de sujeitos leitores quanto de sujeitos leitores literários em minha pesquisa e foi verbalizada, de modo geral, pelo familiar que não tinha ou que tinha poucas práticas de leitura: "ler demais leva à loucura ou à morte". Perguntei-me o que gera tão corrente temor da leitura? Um dos sujeitos deste estudo, leitor contumaz, cuja mãe temeu por sua vida, arriscou uma explicação: quanto mais a pessoa lê, mais ela sabe, o que lhe causa indignação, indignação essa que se traduz em angústia ou a 
torna uma revolucionária. A angústia levaria à insanidade e o caráter revolucionário, à repressão e à morte. A questão das representações negativas que a leitura pode assumir parece-me bastante instigante.

Retomando Zago, citada na epígrafe deste capítulo, chego ao final de um itinerário sentindo-me grata pelo muito aprendi não apenas com os autores consagrados mas também com os sujeitos deste estudo. Saí em busca de leitores literários e de fato encontrei-os. Mas encontrei também leitores, que me mostraram que - a despeito de condições de formação extremamente adversas na infância e adolescência - com acesso a material impresso e algumas mediações qualificadas e cativantes, que propiciem ao sujeito vivenciar o prazer e o sentido de saber e de ler, sempre existirá (resistirá) uma possibilidade de constituição leitora, ainda que mais tardia. 
Referências bibliográficas 
ABRAMO, H. W. Grupos juvenis dos anos 80 em São Paulo: um estilo de atuação social. Dissertação (mestrado). Universidade de São Paulo, 1992.

ABREU, M. Cultura letrada: literatura e leitura. São Paulo: Editora UNESP, 2004.

As variadas formas de ler. In: PAIVA, A. et al. (Orgs) No fim do século: a diversidade - o jogo do livro infantil e juvenil. Belo Horizonte: Autêntica, 2000.

Da maneira correta de ler: leituras das belas artes no Brasil colonial. In: ABREU, M. (Org.). Leitura, história e história da leitura. Campinas: Mercado de Letras, 1999.

BAKHTIN, M. Marxismo e filosofia da linguagem. São Paulo: HUCITEC, 1979.

BARBIER, F; LAVENIR, C. B. Historia de los médios: de Diderot a internet. Buenos Aires: Ed. Colihue, 1999.

BARTHES, R.; COMPAGNON, A. Leitura. In: Enciclopédia Einaudi v.11 (Oral/Escrito). Lisboa: Imprensa Nacional/Casa da Moeda, 1987.

BOURDIEU, P. Esboço de auto-análise; trad. Sergio Miceli. São Paulo: Companhia das Letras, 2005.

. A escola conservadora: as desigualdades frente à escola e à cultura. In: NOGUEIRA, M.A.; CATANI, A. M. (orgs) Pierre Bourdieu - Escritos de educação. Petrópolis: Editora Vozes, 1998.

. (org.) A miséria do mundo. Petrópolis, RJ: Vozes, 1997.

As regras da arte: gênese e estrutura do campo literário, trad. Maria Lucia Machado, São Paulo, Companhia das Letras, 1996.

1983.

Questões de sociologia. Rio de Janeiro: Editora Marco Zero Limitada,

; PASSERON, J. C. A reprodução: elementos para uma teoria do sistema de ensino. Rio de Janeiro: Livraria Francisco Alves Editora, 1982.

A economia das trocas simbólicas. 6. ed. São Paulo: Perspectiva, 1974.

BRANDÃO, Z. Pesquisa em educação: conversas com pós-graduandos. Rio de Janeiro: Ed. PUC-RJ. São Paulo: Loyola, 2002

BRUNER, J.; WEISSER, S. A invenção do ser: a autobiografia e suas formas. In: OLSON, D. R.; TORRANCE, N. Cultura escrita e oralidade. São Paulo: Ática, 1995.

CALVINO, I. Por que ler os clássicos; tradução Nilson Moulin. São Paulo: Companhia das Letras, 1993.

CANDIDO, A. Vários escritos. São Paulo: Duas Cidades, 2004. 
CARDOSO, S. H. B. A questão da referência: das teorias clássicas à dispersão dos discursos. Campinas: Editora Autores Associados, 2003.

CENPEC; LITTERIS. O jovem, a escola e o saber: uma preocupação social no Brasil. In: CHARLOT, B. (org.) Os jovens e o saber: perspectivas mundiais. Porto Alegre: Artmed, 2001.

CHARLOT, B. O professor na sociedade contemporânea: um trabalhador da contradição. In: Educação e contemporaneidade. Salvador, v. 17, n. 30, p. 1-16, jul./dez., 2008.

Relação com o saber, formação dos professores e globalização: questões para a educação hoje. Porto Alegre: Artmed, 2005.

2001.

(org.) Os jovens e o saber: perspectivas mundiais. Porto Alegre: Artmed,

Editora Artmed, 2000.

Da relação com o saber - Elementos para uma teoria. Porto Alegre: Relação com o saber e com a escola entre estudantes de periferia. Cadernos de Pesquisa, São Paulo, n. 97, maio, p. 47-63, 1996.

CHARTIER, R. Os desafios da escrita. São Paulo: Editora UNESP, 2002. . (Org.). Práticas da leitura. São Paulo: Estação Liberdade, 1996.

CHARTIER, A.; HÉBRARD, J. Discursos sobre a leitura, 1880-1980. São Paulo: Ática, 1995.

CHOMSKY, N. Linguagem e pensamento. Petrópolis, RJ: Editora Vozes, 1971.

COMPAGNON, Antoine. O demônio da teoria: literatura e senso comum. Belo Horizonte: Ed.UFMG, 1999.

CORTI, Ana Paula de Oliveira et al. Que ensino médio queremos? Guia para a realização de grupos de diálogo. São Paulo: Ação Educativa, 2007.

CUNHA, M. A. Acesso à leitura no Brasil: considerações a partir da pesquisa. In: INSTITUTO PRÓ-LIVRO. Retratos da Leitura no Brasil, 2008, 2 $2^{\text {a }}$. ed. Recuperado em 01.ago.2008. http//: www.prolivro.org.br/ipl/publier4.0/dados/anexos.48.pdf

DARNTON, R. O Beijo de Lamourette: mídia, cultura e revolução. São Paulo: Companhia das Letras, 1990.

Boemia literária e revolução. São Paulo: Companhia das Letras, 1987.

DAYRELL, J. A música entra em cena - O rap e o funk na socialização da juventude. Belo Horizonte: Editora da UFMG, 2005.

DELEUZE, G. Lógica do sentido; trad. de Luiz Roberto Salinas Fortes. São Paulo, 
Perspectiva, 1974.

DUARTE, Neide. Frutos do Brasil: histórias de mobilização juvenil. São Paulo: Aracati Agência de Mobilização Social, 2006.

DUBET, F. O que é uma escola justa?: a escola das oportunidades; trad. Ione Ribeiro Vale. São Paulo: Cortez, 2008.

Le déclin de l'institution. Paris: Seuil, 2002.

A formação dos indivíduos e a desinstitucionalização. Contemporaneidade e

Educação. Revista Semestral de Ciências Sociais e Educação. Instituto de Estudos da Cultura e Educação Continuada - IEC, Rio de Janeiro, ano III, n. 3, 1998.

Quando o sociólogo quer saber o que é ser professor. [Depoimento a Angelina Peralva e Marília Sposito]. Revista Brasileira de Educação, ANPED, São Paulo, n. 5 e 6 , 1997.

ELIAS, N. A sociedade dos indivíduos. Rio de Janeiro: Jorge Zahar Editor, 1994.

FERREIRA, N. S. A. A pesquisa sobre leitura no Brasil: 1980 - 2000 - Catálogo analítico de dissertações de mestrado e teses de doutorado. Campinas: FAEP, FE, UNICAMP, 2003.

FREGE, G. Lógica e filosofia da linguagem. São Paulo, Cultrix, Ed. da Universidade de São Paulo, 1978.

GINZBURG, C. O queijo e os vermes: o cotidiano e as idéias de um moleiro perseguido pela Inquisição. São Paulo: Companhia das Letras, 2006.

GOODY, J.; WATT, I. The consequences of literacy. In: GOODY, J. (Ed.) Literacy in traditional societies. New York, Cambridge University Press, 1968.

GROTTA, E. C. B. Processo de formação do leitor: relato e análise de quatro histórias de vida. Dissertação de mestrado, Faculdade de Educação, Universidade Estadual de Campinas, Campinas, 2000.

INSTITUTO BRASILEIRO DE GEOGRAFIA E ESTATÍSTICA (IBGE). Síntese dos Indicadores 2005. Recuperado em 10 jan. 2007. http//: www.ibge.gov.br/home/estatistica/ populacao/trabalhoerendimento/pnad2005.

INSTITUTO PAULO MONTENEGRO, AÇÃO EDUCATIVA, IBOPE. Indicador nacional de alfabetismo funcional 2005. Recuperado em 16 jan. 2007. http//: www.ipm.org.br

INSTITUTO PRÓ-LIVRO. Retratos da Leitura no Brasil, 2008, 2a . ed. Recuperado em 01.agosto. 2008. http//: www.prolivro.org.br

KLEIMAN, A. (org.) Os significados do letramento: uma nova perspectiva sobre a prática social da escrita. Campinas, SP: Mercado de Letras, 1995. 
LACERDA, L. de. Álbum de leitura. Memórias de vida, histórias de leitoras. São Paulo: Ed.Unesp, 2003.

LAHIRE, B. De la théorie de l'habitus à une sociologie psychologique. In: LAHIRE, B. (Org.) Le travail sociologique de Pierre Bourdieu. Paris: La Découverte, 1999.

Ática, 1997.

.Sucesso escolar nos meios populares: as razões do improvável. São Paulo,

Esquisse du programme scientifique d'une sociologie psychologique. Cahiers internationaux de sociologie, vol. CVI, janvier-juin, 1998, p.29-55.

Esboço do programa científico de uma sociologia psicológica. Educação e Pesquisa. São Paulo, v. 34, n. 2, p. 373-389, maio/ago. 2008.

LAJOLO, M. A leitura como moeda de trânsito social [Depoimento a Iracema Nascimento]. Políticas e práticas de leitura no Brasil /Ação Educativa - São Paulo, Ação Educativa, 2003, p. 46-55.

.Literatura: leitores e leitura. São Paulo: Moderna, 2001.

LENOIR, R. Iniciação á prática sociológica. Rio de Janeiro: Vozes, 1996.

LEONTIEV, A. O desenvolvimento do psiquismo. Lisboa: Livros Horizonte, 1978.

LISPECTOR, C. Felicidade clandestina: contos. Editora Sabiá, 1971.

LOPES, W. Vamos ler um livro: iniciativa de um grupo juvenil. In: Políticas e práticas de leitura no Brasil /Ação Educativa - São Paulo, Ação Educativa, 2003, p. 46-55.

LURIA, A. R. (1987). Pensamento e linguagem: as últimas conferências de Luria. Porto Alegre: Artes Médicas.

LYONS, M. Os novos leitores no século XIX: mulheres, crianças e operários. In: CAVAllO, G. e CHARTIER, R. (Org.s). História da leitura no mundo ocidental 2v. São Paulo: Ática, 1999, v. 2.

.; LEAHY, C. A palavra impressa. Rio de Janeiro: Casa da Palavra, 1999.

MAINGUENEAU, D. Gênese dos discursos. Trad. Sírio Possenti) Curitiba, PR: Criar Edições, 2005.

MANUKATA, K. Livro didático: produção e leituras. In: ABREU, M. (Org.) Leitura, história e história da leitura. Campinas: Mercado de Letras, 1999.

MARQUES, M. L. A família e a escola marcando a formação do leitor. Tese de doutorado. Instituto de Psicologia. Universidade de São Paulo, 1999.

MELUCCI, A. Por uma sociologia reflexiva; pesquisa qualitativa e cultura; trad. Maria do Carmo Alves do Bomfim. Petrópolis, RJ: Vozes, 2005. 
MILLS, C. W. A imaginação sociológica; trad. de Waltensib Dutra. Rio de Janeiro: Zahar Editores, 1965.

NOGUEIRA, C. M. M.; NOGUEIRA, M. A. Bourdieu \& a educação. $2^{\text {a }}$. ed. Belo Horizonte: Autêntica, 2006.

NOGUEIRA, M. A.; CATANI, A. (Orgs.) Pierre Bourdieu - Escritos de Educação, Petrópolis, Vozes, 1999.

OLIVEIRA, M. B. e OLIVEIRA, M. K. (orgs). Investigações cognitivas: conceitos, linguagem e cultura. Porto Alegre, Artmed, 1999.

OLIVEIRA, M. K. Escolarização e desenvolvimento do pensamento: a contribuição da psicologia histórico-cultural. In: Revista Diálogo Educacional, Curitiba, v. 4, n. 10, p. 23-34, set/dez. 2003.

A questão da periodização do desenvolvimento psicológico. In: OLIVEIRA, M. K.; SOUZA, D. T. R.; REGO, T. C. (Orgs.) Psicologia, educação e temáticas da vida contemporânea. São Paulo: Moderna, 2002.

Jovens e adultos como sujeitos de conhecimento e aprendizagem. Revista Brasileira de Educação, 12: 59-73, 1999.

Sobre diferenças individuais e diferenças culturais: o lugar da abordagem histórico-cultural. In AQUINO, J. G. (org.) Erro e fracsso na escola: alternativas teóricas e práticas. São Paulo, Summus, 1997.

Letramento, cultura e modalidades de pensamento. In: KLEIMAN, A. B.

(Org.). Os significados do letramento: uma nova perspectiva sobre a prática social da escrita. Campinas, SP: Mercado de Letras, 1995.

Vygotsky: aprendizado e desenvolvimento - um processo sóciohistórico. São Paulo: Editora Scipione, 1993.

; REGO, T. C. Vygotsky e as complexas relações entre cognição e afeto. In: ARANTES, V. (Org.). Afetividade na escola: alternativas teóricas e práticas. São Paulo: Summus, 2003.

OLIVEIRA, G. B. de. O professor de português e a literatura: relações entre formação, hábitos de leitura e prática de ensino. São Paulo, Faculdade de Educação, Universidade de São Paulo (Dissertação de Mestrado), 2008.

PAIS, J. M. Vida cotidiana. Enigmas e revelações. São Paulo: Cortez Editora, 2003.

PATTO, M. H. S. A família pobre a escola pública: anotações sobre um desencontro. In: PATTO, M. H. S. (org.) Introdução à psicologia escolar. 3.ed. São Paulo, Casa do Psicólogo, 1997. 
Paulo: TA Queiroz, 1991.

A produção do fracasso escolar: histórias de submissão e rebeldia. São

PECHEUX, M. Semântica e discurso: uma crítica à afirmação do óbvio. Campinas: Editora da UNICAMP, 1988.

PEREGRINO, M. Desigualdade numa escola em mudança: trajetórias e embates na escolarização pública de jovens pobres. Tese (Doutorado em Educação) - Curso de PósGraduação em Educação, Universidade Federal Fluminense, Niterói, 2006.

PETIT, M. Os jovens e a leitura: uma nova perspectiva. Trad. Celina Olga de Souza. São Paulo: Ed. 34, 2008.

PIAGET, J. A epistemologia genética. Petrópolis, Editora Vozes, 1973.

; CHOMSKY, N. Teorias da linguagem, teorias da aprendizagem: o debate entre Jean Piaget e Noam Chomsky. Organizado e compilado por Massimo PiattelliPalmarini; tradução de Álvaro Cabral. São Paulo: Cultrix e Editora da Universidade de São Paulo, 1983.

PIETRI, E. Práticas de leitura e elementos para a atuação docente. Rio de Janeiro: Lucerna, 2007.

PINO, A. As marcas do humano: às origens da constituição cultural da criança na perspectiva de Lev S. Vigotski. São Paulo: Cortez, 2005

. O social e o cultural na obra de Lev S. Vigotski. In: Educação \& sociedade, n. 71 (2a. ed.): $45-78,2000$

O conceito de mediação semiótica em Vygotsky e seu papel na explicação do psiquismo humano. Cadernos CEDES, n. 24, São Paulo, Papirus, 1990.

PIOVESAN,L. S.R. Sala de leitura: atos, atores e ação. Dissertação [Mestrado]. Escola de Comunicação e Artes da USP, 1999.

RANGEL, E. O. Letramento literário e livro didático de língua portuguesa: “Os amores difíceis". In: PAIVA, A. et al. (Orgs) Literatura e letramento: espaços, suportes e interfaces - O jogo do livro. $1^{\text {a }}$. ed., 1. reimp. - Belo Horizonte: Autêntica / CEALE / FaE / UFMG, 2005.

RATTO, I. Ação política: fator de constituição do letramento do analfabeto adulto. In: KLEIMAN, A. B. (Org.). Os significados do letramento: uma nova perspectiva sobre a prática social da escrita. Campinas, SP: Mercado de Letras, 1995.

REGO, T. C. Memórias de escola: Cultura escolar e a constituição de singularidades. Petrópolis: Vozes, 2003.

Educação, cultura e desenvolvimento: o que pensam os professores sobre as diferenças individuais. In: AQUINO, J. G. (Org.) Diferenças e preconceito na escola: alternativas teóricas e práticas. São Paulo: Summus, 1998. 
Vozes, 1995.

Vygotsky: uma perspectiva histórico-cultural da educação. Petrópolis:

A origem da singularidade do ser humano. Análise das hipóteses de educadores à luz da perspectiva de Vygotsky. São Paulo: Faculdade de Educação, Universidade de São Paulo (Dissertação de Mestrado), 1994.

RIBEIRO, V. M. (Org). Letramento no Brasil: reflexões a partir do INAF 2001. 2. ed. São Paulo: Global, 2003.

. (Org.) Alfabetismo e atitudes: pesquisa com jovens e adultos. Campinas: Papirus; São Paulo: Ação Educativa, 1999.

ROSA, A; VALSINER, J. (Orgs.) The Cambridge handbook of sociocultural psychology. New York: Cambridge University Press, 2007.

ROSSETTI-FERREIRA, M. C. et al. (Orgs.) Rede de significações e o estudo do desenvolvimento humano. Porto Alegre: Artmed, 2004.

SAMPAIO, P. S. O papel do outro social na formação da criança leitora. Dissertação (mestrado). Instituto de Psicologia, Universidade de São Paulo, São Paulo - SP, 2005.

SMOLKA, A. L. Sobre significação e sentido: uma contribuição à proposta da Rede de Significações. In: Rossetti-Ferreira, M. C. et al. (orgs). Rede de significações e o estudo do desenvolvimento humano. Porto Alegre, Artmed, 2004.

Estatuto do sujeito, desenvolvimento humano e teorização sobre a criança. In: FREITAS, M. C. e KUHLMANN Jr. (orgs.). Os intelectuais na história da infância. São Paulo: Editora Cortez, 2002.

1989.

Leitura e desenvolvimento da linguagem. Porto Alegre: Mercado Aberto,

; GÓES, C. (orgs.). A linguagem e o outro no espaço escolar: Vygotsky e a construção do conhecimento. Campinas, Papirus, 1993.

SOARES, M. B. O jogo das escolhas. In: Jogo do Livro VII - As escolhas em jogo. Belo Horizonte: Autêntica/CEALE, (no prelo).

Ler, verbo transitivo. In: PAIVA et al. (Orgs) Leituras literárias: discursos transitivos. Belo Horizonte: Ceale; Autêntica, 2005.

.Leitura e democracia cultural. In: PAIVA, A. et al. (Orgs) Democratizando a leitura: pesquisas e práticas. Belo Horizonte: Ceale; Autêntica, 2004.

. A escolarização da literatura infantil. In: EVANGELISTA, A. A. M et al. (Org.) A escolarização da leitura literária: o Jogo do Livro Infantil e Juvenil. Belo Horizonte: Autêntica, 1999. 
Letramento: um tema em três gêneros. Belo Horizonte: Autêntica, 1998.

SOUZA, R. "Ser homem": percepções, significados e narrativas de rapazes negros e pobres da cidade de São Paulo. Dissertação de Mestrado. Faculdade de Educação, Universidade de São Paulo, São Paulo, 2009.

SPOSITO, M. P. Juventude e educação: interações entre a educação escolar e a educação nãoformal. In: Educação e realidade, v. 33 (2), jul-dez 2008. p. 83-98.

et al. (Orgs.) Juventudes e contemporaneidade. 1. ed. Brasilia:

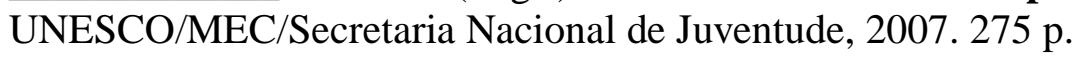

Reflexões e muitas indagações sobre as relações entre juventude e escola no Brasil. In: ABRAMO, H. e BRANCO, Pedro Paulo (orgs.) Retratos da juventude brasileira. Análises de uma pesquisa nacional. São Paulo: Instituto da Cidadania/Editora Fundação Perseu Abramo, 2005. p. 129-148

A sociabilidade juvenil e a rua: novos conflitos e ação coletiva na cidade. In:

Tempo Social; Rev. Sociol. USP, São Paulo, 5 (1-2), p. 161-178, 1993.

TOOP, D. Rap Attack 2. New York, Serpent's Tail, 1991.

VEER, R. V. D.; VALSINER, J. Vygotsky: uma síntese. São Paulo, Unimarco/Loyola, 1996. The Vygotsky Reader. Oxford, Blackwell, 1994.

Blackwell, 1991. Understanding Vygotsky: a quest for synthesis. Oxford,

VIANA, M. J. B. Longevidade escolar em famílias populares: algumas condições de possibilidade. Goiânia: Ed. da UCG, 2007.

VYGOTSKY, L. S. Obras Escogidas I: Problemas teoricos e metodológicos de la psicologia. Madrid, Visor / Centro de Publicaciones del MEC, 1991.

Pensamento e linguagem. São Paulo, Martins Fontes, 1987.

$\overline{\text { Ícone/Edusp, } 1988 .}$

et al. Linguagem, desenvolvimento e aprendizagem. São Paulo, A formação social da mente. São Paulo, Martins Fontes, 1984.

\& Luria, A R. Estudos sobre a história do comportamento: símios, homem primitivo e criança. Porto Alegre. Artes Médicas, 1996.

ZAGO, N. A entrevista e seu processo de construção: reflexões com base na experiência prática de pesquisa. In: ZAGO, N. et al. (org.) Itinerários de pesquisa. Perspectivas qualitativas em sociologia da educação. Rio de Janeiro: DP\&A, 2003.

ZANTEN, A. V. Comprender y hacerse comprender: como reforzar la legitimidad interna y 
externa de los estudios cualitativos. In: Educação e Pesquisa. São Paulo, v. 30, n. 2, p. 301313, maio/ago. 2004.

La "reflexividad" social y SUS efectos sobre la investigación cualitativa de las realidades educativas. In: ZAGO, N.; CARVALHO, M. P.; VILELAT, R. A. T. (Orgs.) Itinerários de pesquisa: perspectivas qualitativas em sociologia da educação. Rio de Janeiro: DP\&A, 2003.

ZILBERMAN, R. Letramento literário: não ao texto, sim ao livro. In: PAIVA, A. et al. (Orgs) Literatura e letramento: espaços, suportes e interfaces - $O$ jogo do livro. $1^{\mathrm{a}}$. ed., 1 . reimp. - Belo Horizonte: Autêntica / CEALE / FaE / UFMg, 2003.

Moderna, 2001.

. Prefácio. In: LAJOLO, M. Literatura: leitores e leitura. São Paulo: 
Anexos 


\section{ANEXO A - AUTORIZAÇÃO PARA PESQUISA}

$\mathrm{Eu}$, portador (a) do R.G. $\mathrm{n}^{\mathrm{o}}$ , declaro que participei espontaneamente da pesquisa de mestrado intitulada: "O letramento literário de jovens nos meios populares", planejada e realizada por Ana Paula Carneiro Renesto, portadora do R.N.E. $n^{\circ}$ W606678-I, estudante de pós-graduação da Faculdade de Educação da Universidade de São Paulo. Minha participação incluiu uma entrevista concedida à pesquisadora, em que relatei minha formação como leitor.

Essa pesquisa terá como principal finalidade produzir material que contribua para se compreender como se dá a constituição de leitores de literatura e poderá servir como fonte para o estudo de futuros pesquisadores e interessados em geral em temáticas da educação contemporânea.

Fui informado (a) pela pesquisadora que terei meu nome mudado, o que protegerá minha identidade.

São Paulo,

Assinatura 


\section{ANEXO B - LISTA DE OBJETIVOS DA PESQUISA ${ }^{98}$}

Objetivo geral: realizar um estudo de natureza qualitativa em caráter exploratório para compreender como se dá o improvável processo de constituição de leitores de literatura no portador livro entre sujeitos de meios populares.

Objetivos específicos:

A) Compreender o que influenciou a gênese do interesse por ler. A freqüência de acesso a material impresso e sua qualidade tiveram algum tipo de influência?

B) Qual foi a freqüência da interação com os mediadores leitores mais experientes? O contato foi constante, esporádico ou até mesmo único? Em que âmbito (família, escola, grupo de pares etc) e como aconteceu a mediação?

1) Como e com que frequiência se deu o acesso a material impresso?

2) Qual foi a mediação exercida pela família?

2.1) Havia práticas de leitura na família?

2.2) Qual a frequiência dessas práticas?

2.3) Que tipo de materiais e portadores circulavam no ambiente doméstico?

2.4) Quais eram as concepções dos atos de leitura e escrita presentes na família?

2.5) Quem fazia a mediação de leitura?

2.6) Como e com que freqüência tal mediação era feita?

3) Qual foi a mediação exercida pela escola?

3.1) Havia práticas de leitura na escola?

3.2) Qual a freqüência dessas práticas?

3.3) Que tipo de material circulava na escola, ou a que tipo de material o sujeito tinha acesso na escola?

3.4) Quais as concepções dos atos de leitura dentro da escola?

3.5) Quem fazia essa mediação?

3.6) Como e com que frequiência tal mediação era feita?

3.7) Qual foi a mediação exercida pelo professor de Língua Portuguesa?

3.8) Outras pessoas fizeram essa mediação, como, por exemplo, outros professores, alunos de outras séries etc?

3.9) Qual foi a mediação exercida pelo livro didático de língua portuguesa?;

4) Qual foi a mediação exercida pela biblioteca (escolar, pública, comunitária)?;

4.1) Que tipo de material circulava na biblioteca, e a que tipo de material o sujeito tinha acesso na biblioteca?

\footnotetext{
${ }^{98}$ Conforme disse antes, para reduzir os riscos que o uso de um roteiro de entrevista muito flexível traria, tentei controlar o que já havia sido coberto ou não no relato do sujeito por meio da lista de objetivos da pesquisa.
} 
4.2) Qual a mediação do atendente da biblioteca?

4.3) Com que freqüência se deu essa mediação?

5) Qual foi a mediação exercida por outras agências socializadoras (instituições religiosas, grupo de pares, etc)?

5.1) Como e com que freqüência se deu essa mediação? 


\section{ANEXO C - ROTEIRO DE ENTREVISTA ${ }^{99}$}

Você se lembra de quando você começou a aprender a ler? Qual é a primeira coisa que você se lembra de ter lido? Você se lembra se foram gibis, revistas, livrinhos?

Qual foi o primeiro livro que você se lembra de ter lido? Qual foi o primeiro livro do qual você gostou? Qual era a história?

E como foi que você escolheu esse livro? Esse livro estava na sua casa, era da escola, de um amigo?

Tinha gibi, revista, livro na sua casa?

Você se lembra quando você começou a se interessar por ler livros? O que você lia? E quando você gostava de ler? E por que você acha que começou a gostar de ler?

E você se lembra de outro livro, que leu em seguida?

Você acha que começou a gostar de ler um certo tipo de livro mais que outro quando? E mais alguém que você conhecia gostava de ler? Ou era só você?

Você se lembra de mais alguém que te incentivou a gostar de ler?

Você gostava da escola? Você acha que algum professor te incentivou a ler?

A escola pedia pra você ler alguma coisa?

Tinha biblioteca na sua escola? Com que frequiência você ia lá? E o que fazia? Você pegava livros da biblioteca da escola?

Você se lembra de ter ido a alguma biblioteca pública? Como foi? Como você foi atendido?

Desde quando você freqüenta esta biblioteca comunitária? Você se lembra das primeiras vezes que veio aqui? Como foi?

Que tipo de livro você lê aqui?

Por que ler é bom? Você lê por quê?

\footnotetext{
${ }^{99}$ Conforme disse antes, no capítulo de Metodologia, o roteiro foi bastante flexível. Assim, as entrevistas
} incluíram perguntas improvisadas e, mesmo as perguntas acima podem ter sido realizadas seguindo outra ordem. 
ANEXO D - TRANSCRIÇÕES DAS ENTREVISTAS (CD-ROM) 
